\title{
Novamente grávida:
}

\section{Adolescentes com maternidades sucessivas em Rondonópolis - MT}

\begin{abstract}
Alcindo José Rosa
Tese apresentada ao Programa de Pós Graduação em Saúde Pública, da Faculdade de Saúde Pública, para obtenção do Título de Doutor em Saúde Pública.
\end{abstract}

Área de concentração: Saúde Materno Infantil

Orientador: Prof. Dr. Alberto Olavo Advincula Reis

São Paulo 
É expressamente proibida a comercialização deste documento, tanto na sua forma impressa como eletrônica. Sua reprodução total ou parcial é permitida exclusivamente para fins acadêmicos e científicos, desde que na reprodução figure a identificação do autor, título, instituição e ano da tese. 
Dedico aos meus pais que sempre me apoiaram, apesar de não entenderem ao certo 'para que tanto estudo'. 


\section{Agradeço}

Às adolescentes, pela disponibilidade em oferecer tão íntimas partes de suas histórias de vida a um estranho;

Ao Prof. Alberto, pelos ensinamentos, orientações e confiança que depositou nos meus trabalhos;

À Faculdade de Saúde Pública, por tão nobre missão;

Aos professores da Faculdade de Saúde Pública, dos quais muito me orgulho em tê-los como mestres;

Aos funcionários da Faculdade de Saúde Pública, Leandro e Iara, do Departamento de Saúde Materno-Infantil, pelo esmero com que sempre me atenderam;

Ao José e Maria Luiza, bibliotecários da Faculdade de Saúde Pública, pela prestimosidade e dicas sobre as notações bibliográficas e pesquisa em base de dados;

À tia Mercedes e à Ângela, por tão confortavelmente terem me hospedado em seus apartamentos em São Paulo e ao Igor, por gentilmente ceder parte de seu aposento para meu repouso;

Aos colegas de pós-graduação, em especial, ao André, por se dispor a ouvir as dificuldades;

Aos professores e amigos da UFMT, em especial, ao Fausto, Laura, Leonardo, Graciela e Raquel, pelas boas conversas sobre o doutorado;

Às alunas do Curso de Psicologia da UFMT, em especial, Marisa, Daiene, Renata, Jinessa e Monara, pela colaboração oferecida;

À Secretaria Municipal de Saúde (SMS) de Rondonópolis-MT, em especial, à Elizita, Coordenadora dos Programas Especiais, pelas autorizações e à Eliane, pelos dados do SISPRENATAL; 
Aos funcionários da Vigilância Epidemiológica da SMS de Rondonópolis-MT, Magda e Vagner, por colaborarem no acesso aos dados do SINASC;

Aos Coordenadores das Unidades de Saúde da SMS de RondonópolisMT, pela receptiva acolhida;

Aos agentes comunitários de saúde da SMS de Rondonópolis-MT, pela prestimosidade com que nos informaram e acompanharam;

À minha irmã Ivone, pelas dicas de Língua Portuguesa;

Á Luciana, ex-coordenadora do GIPA/Assis e aos colegas que lá deixei, por compreenderem minhas ausências enquanto cumpria os créditos;

Aos meus filhos: aos grandes, por suportarem as saudades, aos pequenos, por me lembrarem que devia brincar enquanto escrevia;

À Marisa, minha companheira, por tão dedicada parceria e apoio. 
"Meu Deus do céu, não tenho nada a dizer. O som de minha máquina é macio. Que é que eu posso escrever? Como recomeçar a anotar frases? A palavra é o meu meio de comunicação. Eu só poderia amá-la. Eu jogo com elas como se lançam dados: acaso e fatalidade. A palavra é tão forte que atravessa a barreira do som. Cada palavra é uma idéia. Cada palavra materializa o espírito. Quanto mais palavras eu conheço, mais sou capaz de pensar o meu sentimento. Devemos modelar nossas palavras até se tornarem o mais fino invólucro dos nossos pensamentos. Sempre achei que o traço de um escultor é identificável por uma extrema simplicidade de linhas. Todas as palavras que digo - é por esconderem outras palavras. Qual é mesmo a palavra secreta? Não sei é porque a uso? Não sei porque não ouso dizê-la? Sinto que existe uma palavra, talvez unicamente uma, que não pode e não deve ser pronunciada. Parece-me que todo o resto não é proibido. Mas acontece que eu quero é exatamente me unir a essa palavra proibida. Ou será? Se eu encontrar essa palavra, só a direi em boca fechada, para mim mesma, senão corro o risco de virar alma perdida por toda a eternidade. Os que inventaram o Velho Testamento sabiam que existia uma fruta proibida. As palavras é que me impedem de dizer a verdade. Simplesmente não há palavras. $O$ que não sei dizer é mais importante do que o que eu digo. Acho que o som da música é imprescindivel para o ser humano e que o uso da palavra falada e escrita são como a música, duas coisas das mais altas que nos elevam do reino dos macacos, do reino animal, e mineral e vegetal também. Sim, mas é a sorte às vezes. Sempre quis atingir através da palavra alguma coisa que fosse ao mesmo tempo sem moeda e que fosse e transmitisse tranqüilidade ou simplesmente a verdade mais profunda existente no ser humano e nas coisas. Cada vez mais eu escrevo com menos palavras. Meu livro melhor acontecerá quando eu de todo não escrever. Eu tenho uma falta de assunto essencial. Todo homem tem sina obscura de pensamento que pode ser o de um crepúsculo e pode ser uma aurora. Simplesmente as palavras do homem".

Sobre a Escrita - Cecília Meireles 


\section{RESUMO}

ROSA, A. J. Novamente grávida: adolescentes com maternidades sucessivas em Rondonópolis-MT. 2007. Tese (Doutorado em Saúde Pública) - Faculdade de Saúde Pública da Universidade de São Paulo, São Paulo, 2007.

As maternidades sucessivas na adolescência constituem uma situação complexa que requer da adolescente a administração de três dimensões, que inspiram cada uma delas, ponderações: o processo de adolescência, a maternidade e a criação de vários filhos, com o agravante de ocorrerem, em nosso país, em contexto de considerável desigualdade sócio-econômica. Tendo em vista tal problemática, foi desenvolvida a pesquisa em tela voltada à caracterização e análise dos contextos reprodutivos, sócioeconômicos e individuais de adolescentes com sucessivas maternidades no município de Rondonópolis-MT/Brasil. Foram selecionadas 49 participantes, usuárias do SUS, com idade entre 15 e 19 anos, com pelo menos um filho nascido vivo e que estavam novamente grávidas. Para a obtenção dos dados foi usado questionário sócio-econômico, entrevista aberta e entrevista semi-estruturada, após prévia aprovação pelo Comitê de Ética em Pesquisa da FSP-USP e a devida anuência das participantes de acordo com os termos do TCLE que lhes foi submetido. Outras informações foram obtidas por consultas aos Relatórios do Ministério da Saúde e bancos de dados SINASC e SISPRENATAL. Os dados foram organizados e analisados quanti-qualitativamente. Os dados quantitativos oriundos de fontes secundárias e do questionário aplicado foram organizados em tabelas de porcentagem. As respostas obtidas junto às adolescentes nas entrevistas e parte do questionário foram objeto de análise de conteúdo conforme os critérios classicamente aceitos. A dinâmica reprodutiva local mostrou-se consoante às tendências do país, tais como diminuição da porcentagem de gravidezes entre adolescentes, inclusive, entre aquelas com maternidades sucessivas. Entre as participantes, a primeira gravidez deu-se, em média, aos 15 anos e 2 meses, a segunda, aos 17 anos e 4 meses e a terceira aos 18 anos e 2 meses. Esse curto período pareceu expô-las às dificuldades cotidianas da criação dos filhos e as impediu de protagonizarem outros papéis sociais, como a de estudante e trabalhadora. Assim, se a primeira maternidade pode fornecer sentidos positivos para muitas das vivências das adolescentes e até mesmo colaborou para que construíssem uma identidade - ser mãe - e passassem a ocupar um lugar socialmente valorizado, as maternidades sucessivas pareceram ter contornos menos estruturantes, até mesmo, agravando as já precárias condições sócio-econômicas que as circundavam. Essa situação, pareceu igualmente ter impedido-lhes o acesso às 'janelas de oportunidades', principalmente, aquelas articuladas à escolarização. Concluiu-se que as 'maternidades sucessivas na adolescência' constituem-se, pelas suas conseqüências, num fenômeno diferente ao da 'primeira gravidez na adolescência'. Enquanto essa se mostrou mais integrada às demandas da adolescente, as maternidades subseqüentes agravaram suas necessidades, multiplicando as situações adversas a elas associadas.

Descritores: Saúde Sexual e Reprodutiva; Maternidade de Adolescentes, Intervalo entre Nascimentos. 


\begin{abstract}
ROSA, A. J. Pregnancy again: consecutive motherhood in teenage women in Rondonópolis-MT. 2007. Thesis (Doctorate in Public Health) - Public Health School of São Paulo University, São Paulo, 2007.
\end{abstract}

The consecutive motherhood in teenage women are a complex situation which requires from the teenager the administration of three dimensions and each one of them inspire careful considerations: the adolescence process, motherhood and the raising of several children in a context of considerable social-economical disparity. Having this type of problem in mind, the research was developed aiming to the characterization and analyzes of the reproductive, social-economical and individual contexts of teenagers who have had consecutive pregnancies in the county of Rondonópolis-MT / Brazil. It was selected 49 participants, user of SUS with an age-rate from 15 to 19 years old, who have had, at least, one child that was born alive and were pregnant again. In order to obtain this socialeconomical data a questionnaire, an opened interview and a semi-structured interview were used after the Comitê de Ética em Pesquisa da FSP-USP's approval and after the participants' consent in agreement with the TCLE terms that were presented to them. Other informations were obtained by consulting the reports from the Department of Health (Ministério da Saúde) and the SINASC and SISPRENATAL data files. The data were organized and analyzed in terms of quantity and quality. The quantity data from secondary sources and from the questionnaire were organized in percentage charts. The answers obtained from the teenagers in the interviews and part of the questionnaire had its content analyzed in agreement with previously accepted criteria. The local reproductive dynamic presented itself consonant with the countries' tendencies, such as the reduction of the percentage of pregnancies among teenage women including those with consecutive pregnancies. Among the participants, the first pregnancy took place at the age of 15 years and 02 months old (approximately), the second at the age of 17 years and 04 months old and the third pregnancy took place at the age of eighteen years and 02 months old. This short gap seemed to have exposed them to everyday difficulties in raising their children and kept them from playing other social roles such as the student and working professional. So, if the first pregnancy could provide positive experiences to the lives of these teenagers and even cooperate for the construction of an identity - to be a mother - and, by this, belong to a respectable and social space, the consecutive pregnancies seem to have less structural shapes, inclusively, by aggravating the difficult social-economical situations, that have already existed, surrounding these mothers. This situation equally seemed to have kept them away from the "window of opportunities", especially those articulated with education. One concludes that the consecutive pregnancies in the adolescence, by its consequences, are a different phenomenon if compared to first pregnancy in the adolescence. While the last one seemed more integrated to the teenager's demands, the consecutive pregnancies worsened their needs, multiplying associated adverse situations related to them.

Descriptors: Sexual and Reproductive Health; Teenager motherhood; Birth Intervals 


\section{ÍNDICE}

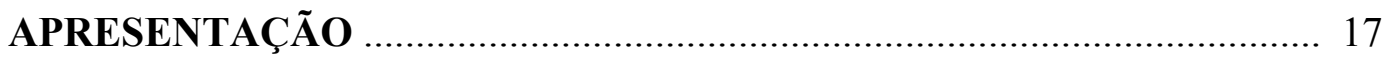

\section{CAPÍTULO I: O PROBLEMA DE PESQUISA}

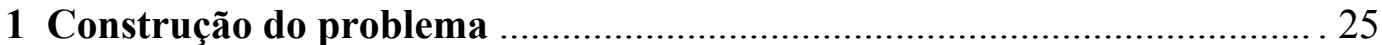

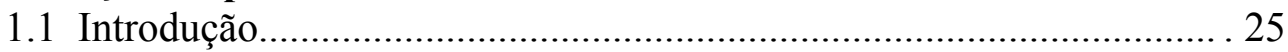

1.2 A gravidez e a maternidade em adolescentes................................... . 39

1.3 Maternidades sucessivas na adolescência ......................................... 49

1.4 A maternidade e a feminilidade................................................... 59

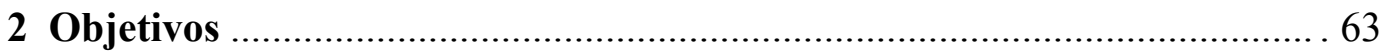

\section{CAPÍTULO II: OS CAMINHOS}

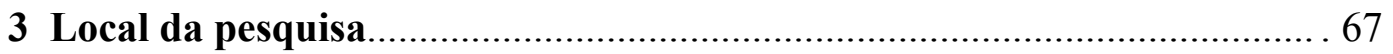

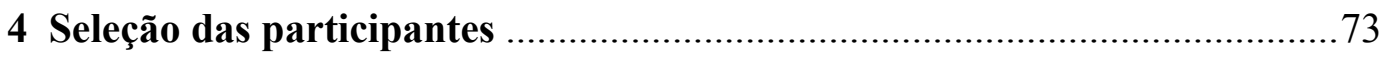

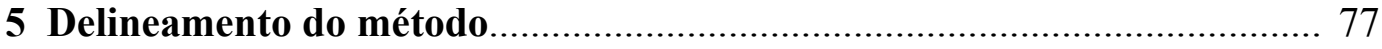

5.1 Fontes, instrumentos e técnicas..................................................... 78

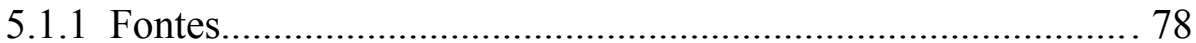

5.1.2 Questionário.................................................................... 78

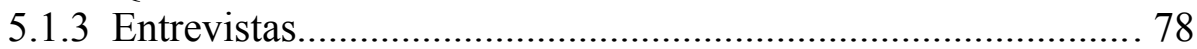

5.1.3.1 Entrevistas abertas ................................................ 78

5.1.3.2 Entrevistas Semi-estruturadas.................................... 80

5.1.4 Pré-teste e registro das informações....................................... 80

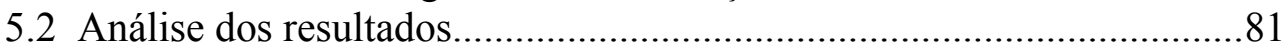

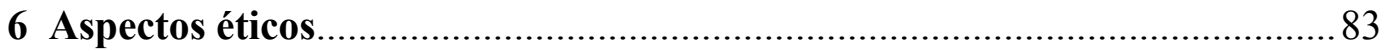

\section{CAPÍTULO III: OS ENCONTROS E DESENCONTROS}

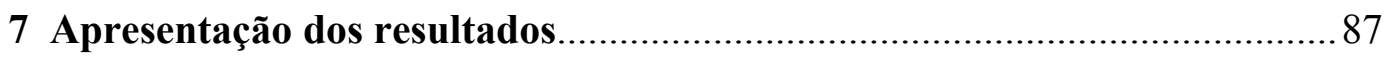

7.1 A dinâmica reprodutiva da população adolescente de

Rondonópolis - MT no período 2000/2006..................................... 89

7.2 Contexto sócio-econômico das adolescentes..................................... 93

7.2.1 Acesso à Moradia....................................................................93 


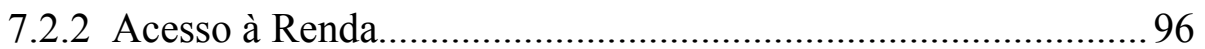

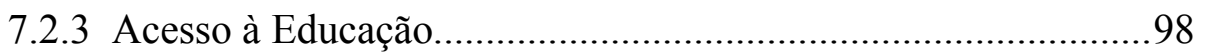

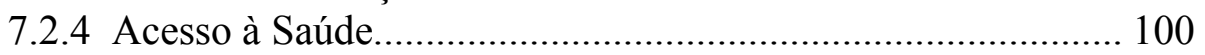

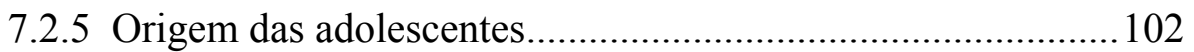

7.2.6 Relação das adolescentes com pai e mãe.................................104

7.3 Contexto de iniciação sexual e reprodutiva........................................ 113

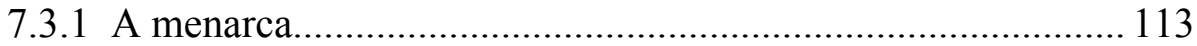

7.3.2 A iniciação sexual e a primeira maternidade........................... 117

7.3.3 O uso de contraceptivos antes da primeira maternidade......... 122

7.4 As maternidades sucessivas em Rondonópolis-MT........................... . 127

7.4.1 'Querer e não querer' a primeira maternidade ....................... 127

7.4.2 Os imprevistos da segunda e terceira maternidade ............... 132

7.4.3 As preocupações da segunda e terceira maternidade ............. 138

7.4.4 As adolescentes e as tentativas de provocar o aborto............. 141

7.4.5 A relação das adolescentes com o pai do filho......................... 144

7.4.6 Reação do parceiro diante da gravidez ................................. . 149

7.4.7 Mudanças trazidas pela maternidade..................................... 154

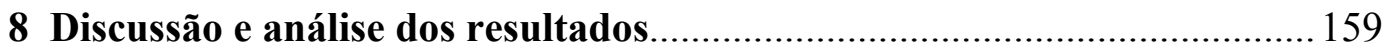

8.1 A dinâmica reprodutiva da população adolescente de

Rondonópolis-MT e do Brasil e as maternidades sucessivas.

8.2 As maternidades sucessivas e a idade da menarca, da iniciação sexual e da primeira gravidez........................................................ .167

8.3 Maternidades sucessivas e o grupo familiar de origem......................173

8.4 Maternidades sucessivas e as parcerias afetivo-sexuais..................... 177

8.5 Maternidades sucessivas e o uso dos métodos contraceptivos............. .183

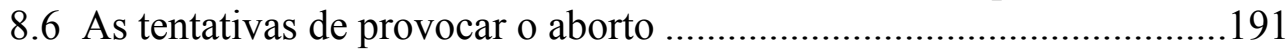

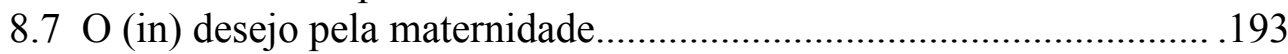

8.8 Maternidades sucessivas e a 'periferia da periferia' ............................201

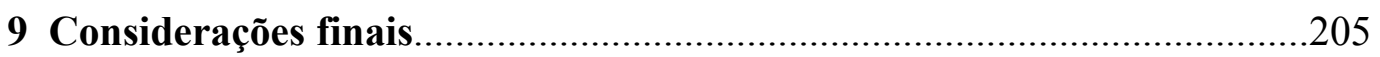

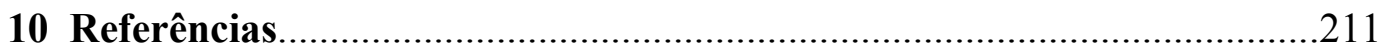

\begin{abstract}
ANEXOS
Anexo I: Modelo do questionário sócio-econômico........................................223

Anexo II: Roteiro de entrevista semi-estruturada........................................ 227

Anexo III: Modelo do Termo de Consentimento Livre e Esclarecido...............231

Anexo IV: Geoprocessamento da localização das residências de adolescentes com maternidades sucessivas na cidade de Rondonópolis-MT, 2007.




\section{LISTA DE TABELAS}

Tabela 1 - Distribuição de renda por classe social em Rondonópolis-MT, 2005 .69

Tabela 2 - Adolescentes com maternidades sucessivas selecionadas para a pesquisa em Rondonópolis-MT, 2007.

Tabela 3 - Quantidade de FNV e gestação em que se encontravam adolescentes com maternidades sucessivas selecionadas para a pesquisa em Rondonópolis-MT, 2007.

Tabela 4 - FNV em adolescentes (15 a 19 anos) com dois ou mais FNV em relação ao total de FNV na população adolescente de RondonópolisMT -2000 a 2006

Tabela 5 - FNV em adolescentes (15 a 19 anos) com dois ou mais FNV em relação ao total de FNV na população de Rondonópolis-MT - 2000 a

2006.

Tabela 6 - FNV em adolescentes conforme faixa etária em relação ao total de FNV no restante da população de Rondonópolis-MT - 2000 a 2006.90

Tabela 7 - FNV em adolescentes conforme faixa etária na população adolescente de Rondonópolis-MT - 2000 a 2006

Tabela 8 - FNV em adolescentes (10 a 19 anos) segundo escolaridade no município de Rondonópolis-MT - 2000 a 2006.

Tabela 9 - Tipo de parto realizado em adolescentes (10 a 19 anos) com FNV em Rondonópolis-MT-2000 a 2006.

Tabela 10 - Vínculo mantido com o domicílio por adolescentes com maternidades sucessivas em Rondonópolis-MT, 2007.

Tabela 11 - Pessoas coabitantes por domicílio com adolescentes com maternidades sucessivas em Rondonópolis-MT, 2007.

Tabela 12 - Rendimento mensal dos provedores de adolescentes com maternidades sucessivas em Rondonópolis-MT, 2007.

Tabela 13 - Total da renda das pessoas com as quais coabitam adolescentes com maternidades sucessivas em Rondonópolis-MT, 2007.

Tabela 14 - Vínculo mantido entre adolescentes com maternidades sucessivas e o responsável pelo domicílio em Rondonópolis-MT, 2007. 
Tabela 15 - Pessoas que trabalham e coabitam em domicílio com adolescentes com maternidades sucessivas em Rondonópolis-MT, 2007.

Tabela 16 - Escolaridade de adolescentes com maternidades sucessivas em Rondonópolis-MT, 2007.

Tabela 17 - Repetência escolar entre adolescentes com maternidades sucessivas em Rondonópolis-MT, 2007.

Tabela 18 - Adolescentes com maternidades sucessivas conforme número de consultas médicas no pré-natal por gestação em Rondonópolis-MT, 2007.

Tabela 19 - Estado de origem dos familiares e das adolescentes com maternidades sucessivas em Rondonópolis-MT, 2007.

Tabela 20 - Vínculo entre os progenitores das adolescentes com maternidades sucessivas em Rondonópolis-MT, 2007.

Tabela 21 - Número de FNV de mães das adolescentes com maternidades sucessivas em Rondonópolis-MT, 2007.

Tabela 22 - Idade da primeira gravidez das mães das adolescentes com maternidades sucessivas em Rondonópolis-MT, 2007.

Tabela 23 - Idade da menarca conforme faixa etária das adolescentes com maternidades sucessivas em Rondonópolis-MT, 2007.

Tabela 24 - Acesso a informações sobre sexo e sexualidade entre adolescentes com maternidades sucessivas em Rondonópolis-MT, 2007.

Tabela 25 - Vínculo mantido com o parceiro na iniciação sexual por adolescentes com maternidades sucessivas em Rondonópolis-MT, 2007.

Tabela 26 - Idade do parceiro na primeira gravidez entre adolescentes com maternidades sucessivas em Rondonópolis-MT, 2007.

Tabela 27 - Idade da primeira relação sexual conforme faixa etária entre adolescentes com maternidades sucessivas em Rondonópolis-MT, 2007.

Tabela 28 - Tempo entre o início da vida sexual e a primeira gravidez entre adolescentes com maternidades sucessivas em Rondonópolis-MT, 2007.

Tabela 29 - Mês gestacional de 'descoberta' da gravidez entre adolescentes com maternidades sucessivas em Rondonópolis-MT, 2007. 
Tabela 30 - Idade da primeira gravidez conforme faixa etária entre adolescentes com maternidades sucessivas em Rondonópolis-MT, 2007.

Tabela 31 - Tempo de amamentação do primeiro FNV em adolescentes com maternidades sucessivas em Rondonópolis-MT, 2007.

Tabela 32 - Idade de ocorrência de gravidezes entre as adolescentes com maternidades sucessivas em Rondonópolis-MT, 2007.

Tabela 33 - Tempo entre parto e a nova gravidez entre adolescentes com maternidades sucessivas em Rondonópolis-MT, 2007.

Tabela 34 - Intenção de realizar aborto entre adolescentes com maternidades sucessivas em Rondonópolis-MT, 2007.

Tabela 35 - Tempo de relacionamento com o pai do primeiro filho até que ficasse grávida pela primeira vez entre adolescentes com maternidades sucessivas em Rondonópolis-MT, 2007.

Tabela 36 - Tempo de relacionamento com pai do segundo filho até que ficasse grávida pela segunda vez entre adolescentes com maternidades sucessivas em Rondonópolis-MT, 2007.

Tabela 37 - Tempo de relacionamento com o pai do terceiro filho até que ficasse grávida pela terceira vez entre adolescentes com maternidades sucessivas em Rondonópolis-MT, 2007.

Tabela 38 - Número de parceiros, pais dos filhos de adolescentes com maternidades sucessivas em Rondonópolis-MT, 2007.

Tabela 39 - Número de parceiros sexuais de adolescentes com maternidades sucessivas em Rondonópolis-MT, 2007.

Tabela 40 - Reação ao saber da gravidez de parceiros de adolescentes com maternidades sucessivas em Rondonópolis-MT, 2007. 


\section{APRESENTAÇÃO}

O panorama das investigações sobre a gravidez e a maternidade na adolescência contempla dois campos de debates razoavelmente bem definidos. O primeiro toma a gravidez na adolescência como um "problema", pois concebe o desenvolvimento humano como algo racional, linear e passível de planejamentos.

Do ponto de vista dessa abordagem, a gravidez e a maternidade na adolescência atrapalhariam o amadurecimento biológico e desenvolvimento psíquico da adolescente, que se supõe, seja possível e necessário para a vida adulta e reprodutiva, além de comprometer sua inserção na vida social. Decorrência imediata dessa perspectiva são os conceitos de gravidez precoce, não planejada e indesejada.

O segundo campo de debates toma a gravidez e a maternidade na adolescência como um fenômeno relativo, não universal, a começar pela própria concepção de adolescência, que é vista como um período de grandes experimentações e que possibilitam o acesso do adolescente à diversidade humana, à construção de si e do outro e, finalmente, à singularidade.

Nessa perspectiva, a sexualidade, a gravidez e a maternidade na adolescência são pensadas a partir de um ponto de vista sócio-histórico e não são consideradas como "problemas", mas como elementos que se agregam à dinâmica reprodutiva de indivíduos e populações. O exercício da sexualidade e a ocorrência da gravidez e maternidade integram os possíveis arranjos individuais e sociais frente aos diversos contextos, desde o demográfico, o das condições de vida até os culturais, históricos e subjetivos.

Obter certa clareza acerca do pano de fundo das discussões acerca da(s) gravidez(es) e da(s) maternidade(s) na adolescência não foi empreita simples, aliás, o cenário que agora se tornou relativamente claro, outrora fora muito obscuro. Construí muitas perguntas de partidas, muitos parágrafos, muitos conceitos, muitos pré-projetos, todos igualmente insustentáveis, um a um 
deletados e reconstruídos. Mas só quando se escreve é que se sabe a dor de apagar uma sílaba, quem dirá um parágrafo, um conceito, um projeto, um capítulo.

Foi assim nesses últimos tempos, mas foi necessário. A construção do conhecimento é feita de idas e vindas. Entretanto, não foi apenas o que está escrito que foi relativamente aperfeiçoado, mas também o escritor. Entretanto, esse é o fim desta história, o começo é de outro jeito!

Tão logo terminei minha graduação em Psicologia, em fins de 1994, iniciei minha trajetória na saúde pública como psicólogo concursado pela Prefeitura Municipal de Assis, interior do estado de São Paulo, localidade onde nasci, criei-me e me formei. Inicialmente, fui trabalhar num Ambulatório de Saúde Mental.

A precariedade dos recursos e a forma da assistência à saúde mental me preocupavam. Também assustava a diversidade de expressão do sofrimento psíquico, o que me levou a realizar a pesquisa de mestrado nesse campo. Nesta época, passei também pela experiência de administrar tal serviço de saúde, o que me colocou muito próximo das contingências da administração pública e dos vieses políticos que a cercam. Essa vivência foi muito proveitosa! Ao final de quatro anos, havia, junto com a equipe, transformado o velho ambulatório num Centro de Reabilitação Psicossocial.

Meu próximo passo na saúde pública foi dado em direção à atenção básica em saúde. Fui atender, a partir de 2001, num "posto de saúde" de um bairro periférico de Assis-SP. Novamente, a precariedade do serviço e as necessidades da população eram aviltantes.

Retrospectivamente, é nesse momento que posso situar o início de meu interesse pelo que, anos mais tarde, culminou no presente trabalho. Havia uma demanda considerável de adolescentes para atendimentos na unidade de saúde. Muitas estavam grávidas e eram atendidas no serviço de pré-natal. Dessas, algumas queriam "passar no psicólogo" e eram encaminhadas a mim.

Aos poucos, percebi que embora particulares, as demandas eram muito parecidas e que o trabalho em grupo poderia dar bons resultados. Foi o que fiz, 
mas, tendo em vista que o espaço da unidade de saúde era insuficiente para abrigar os grupos, realizava os encontros ora num espaço cedido por um restaurante próximo, ora num espaço de convivência de uma empresa de jardinagem.

Nessa época, comecei também a realizar trabalhos de prevenção às ISTs, ao HIV e à ocorrência de gravidez durante a adolescência numa escola do bairro. Começava a consolidar em minha trajetória na saúde pública o interesse pelas questões pertinentes à sexualidade adolescente. Desse trabalho, resultou em 2003, um convite para que prestasse meus serviços no Ambulatório de AIDS de Assis-SP (GIPA/COAS), que incluía também, o serviço de triagem sorológica e de prevenção às infecções sexualmente transmissíveis.

Nesse serviço, encontrei-me novamente com as adolescentes grávidas. Dessa vez, eram muitas; não apenas aquelas de um bairro, mas de todo o município, pois todas as mulheres grávidas da cidade passavam pelo serviço para realizar, como parte do pré-natal, o exame sorológico para HIV e sífilis. Um dos trabalhos realizados era o aconselhamento coletivo para IST, HIV e AIDS, que antecedia a coleta sanguínea para os exames. Outro serviço prestado era a divulgação individual dos exames positivos e negativos do HIV para os examinados.

Nas divulgações, aproveitava para, além de avaliar a vulnerabilidade ao HIV, conversar com as adolescentes acerca das circunstâncias de ocorrência da gravidez e desenvolvimento da gestação, as expectativas quanto ao parto e ao futuro bebê e repercussões da gravidez entre seus familiares. Desde então, vislumbrava nessas atividades a possibilidade de realizar uma pesquisa de doutorado na área da maternidade. Por outro lado, estava profundamente envolvido com as questões relativas à continuidade da vida. Eu ia ser pai pela segunda vez!

Concomitante a esse percurso de trabalhador da saúde pública, também me esforçava para aperfeiçoar minha carreira acadêmica. Desde o final do mestrado em 2000 lecionei, tanto na universidade pública, quanto na particular, 
entretanto, foram vínculos empregatícios que ofuscaram meu gosto pela pesquisa, prazer que parece existir desde o berço!

Todas essas vivências, grande parte vividas no âmbito da saúde pública, permitiram que me posicionasse em defesa da 'coisa pública' e das esferas coletivas de decisão. Proporcionou-me também experiências que certamente colaboram para que, agora no ambiente acadêmico, possa articular, com maior desenvoltura a teoria e a prática.

Nos idos de 2005, também estava grávido de idéias, havia iniciado o doutorado pela Faculdade de Saúde Pública da USP e isso era uma grande conquista para um "menino" nascido na roça. Apesar das dificuldades das viagens, das eternas noites mal dormidas em ônibus, dos dias amanhecidos no grêmio estudantil, no subsolo da Faculdade de Saúde Pública, a cidade de São Paulo era misteriosa, as disciplinas do curso desafiadoras e o ambiente intelectual, cativante.

Mas o que primeiro impressionou esse "estrangeiro" na cidade de São Paulo foram seus cheiros. O olfato existe antes que outros sentidos estejam despertos antes mesmo, que a visão. Em São Paulo, tem cheiro de tudo, do Tietê, do metrô, de comida, de poluição, de mendigo, de tinta, de gente, de lixo, de pastel, de banheiro, de produto falsificado, de elevador, de limpeza, de livro, de calçada, de escritório, de indústria, de asfalto, de flores, entre outros odores.

$\mathrm{O}$ que em seguida me cativou foi a diversidade com que a cidade se espreita para o olhar. Como pode tamanha paisagem de gente? Como é possível tamanha variedade de pessoas, de edificações, de estilos, de possibilidades de sobrevivência, de jeitos de pensar, de vestir, de outdoors, de livros, de cores, de filmes, de badulaques, de tentações, de veículos, de tatuagens e piercings, de conhecimento, de pichações, de concreto, de lugares cult, de calçadas.

Por fim, o que parece embriagar qualquer estrangeiro é o que se ouve. Não na rua, que nela só tem murmúrios, sons indefinidos, gritos, buzinas, apitos, sirenes, o que só aumenta a sensação de impotência frente às grandezas que se alternam na metrópole: A riqueza e a miséria, o belo e o feio, o limpo e o sujo, o 
moderno e o arcaico, o sadio e o doente, o grande e o pequeno, o hospital e o cemitério e, assim por diante. Mas o que se ouve do conhecimento! Esse provoca o pensamento, sacode a gente, transforma, dá ânsia de conhecer. Parece que não podemos contar com nada mais, apenas com o (des) conhecimento!

Provocados os sentidos, os sentimentos e o pensamento, percebi que também no interior da FSP-USP, a diversidade estava presente. Foi surpreendente encontrar pesquisadores das mais diversas filiações e graduações: urbanistas, advogados, psicólogos, médicos, dentistas, farmacêuticos, psicanalistas, epidemiologistas, ecologistas, enfermeiros, pediatras, ecologistas, ginecologistas, feministas, entre tantos outros. Foi num ambiente de agradáveis surpresas que cumpri os créditos.

Mas, e a pesquisa com as adolescentes grávidas? Como pensar a questão? Dissipadas as arestas conceituais, o tema se consolidou, mas um fato novo surgiu no início de 2006. Assumi o cargo de professor assistente na Universidade Federal de Mato Grosso, em Rondonópolis-MT.

Com isso, mudei-me do Estado de São Paulo e, conseqüentemente, optei por colher os dados na nova terra, o que, aliás, só veio beneficiar a pesquisa, principalmente, por que a região é muito carente de investigações que forneçam dados locais para o panorama científico nacional e por tratar-se de uma cidade com características de desenvolvimento ímpares.

Foi a partir desse cenário, que o trabalho que doravante é apresentado, muito mais que o resultado do emprego de um método de pesquisa, é a combinação de uma porção de ingredientes, em especial, meu amadurecimento intelectual sobre a temática.

Seria impossível apresentar todo o caminho percorrido, mas ele existiu e foi longo. Exigiu mudanças conceituais importantes sobre a maneira como eu olhava o mundo e os fenômenos reprodutivos que podem ocorrer durante a adolescência e sobre a própria adolescência. Tive que me ater às questões de gênero, tão negligenciada em nossas graduações, aos conceitos de 
vulnerabilidade, de sustentabilidade, de gravidez precoce, de saúde pública, subjetividade e tantos outros.

Talvez sejam essas questões que tornam esta pesquisa relevante e com alguma originalidade e que a tornam apta a colaborar na construção de políticas públicas dirigidas aos adolescentes e ao exercício da sexualidade na adolescência. 
CAPÍTULO I

O PROLEMA DE PESQUISA 


\section{1 - CONSTRUÇÃO DO PROBLEMA}

\section{1 - INTRODUÇÃO}

O processo de desenvolvimento humano guarda em si experiências muito peculiares, entretanto, a adolescência é caracterizada por intensas transformações das formas como o ser humano age consigo, em sociedade, e com seu corpo. Esses aspectos interagem, avançam e recuam, propiciam conflitos, elaborações e novos conflitos até que a vida adulta se mescla ao fantástico mundo infantil, sem, contudo, dar fim às idas e vindas.

Entretanto, durante algum tempo a adolescência esteve confundida com a puberdade, tal era a importância que se dava apenas aos aspectos biológicos que passavam a ser externalizados nesse período. As características culturais, sociais, históricas e psicológicas praticamente não eram consideradas, provavelmente porque se subestimava sua importância.

Atualmente, "a tendência universal é reservar o termo puberdade para as modificações biológicas dessa faixa etária e adolescência para as transformações psicossociais que as acompanham.” (OZÓRIO ${ }^{82}$, p.11, 1989). A puberdade ocorre em todas as populações, entretanto, a adolescência é construída socialmente e mantém características que podem variar de um indivíduo para outro dentro de uma mesma cultura. Portanto, seu desencadeamento e forma de expressão estão, particularmente, ligados ao contexto em que o indivíduo está inserido e à forma como interage com ele.

O conceito de adolescência é uma 'invenção' relativamente recente. A atenção dada a esse período do desenvolvimento humano enquanto momento transitório do mundo infantil para a maturidade é obra dos pensadores do fim do século XIX e início do século XX. Sua valorização no mundo ocidental surge na esteira das descobertas relativas ao "sentimento de família" e do "sentimento de infância”, tal como descritos por ARIÈS ${ }^{6}$ (1978). 
A adolescência só pôde ser especificada à medida que a modernidade avançou. Seu surgimento e caracterização fazem parte de um processo sóciohistórico em que já não era mais possível ao homem ocidental ter seu desenvolvimento até a adultice ocorrendo 'às escondidas' da sociedade. A escola, o exército e os higienistas contribuíram, sobremaneira, para dar visibilidade ao, até então, desconhecido mundo infanto-juvenil e a discipliná-lo (REIS ${ }^{98}, 1993$; OLIVEIRA e $\mathrm{col}^{80}$ ).

Portanto, nesses termos, a adolescência surgiu como uma necessidade do homem moderno e sua 'invenção' pareceu servir, desde então, para 'formar e proteger' o infante. PIGOZZI ${ }^{91}$ (2002), em um estudo sobre os rituais presentes na adolescência, destaca que

A evolução de nossa espécie (...) encarregou-se de inaugurar e posteriormente prolongar esse período de tempo, que então chamamos de adolescência, por até mais de uma década. Quanto maior o nível de especialização requerido para o exercício da maturidade, maior será o tempo necessário para o seu preparo ${ }^{91}(\mathrm{p}$. 28).

BRANDÃO ${ }^{19}$ (2006), a respeito desse prolongamento da juventude, fenômeno típico das classes médias e altas, esclarece que

Nas últimas décadas, o percurso entre a infância e a idade adulta foi profundamente alterado nas sociedades ocidentais modernas. As mudanças no estatuto infantil, o redimensionamento da autoridade parental, as novas normas educativas, as transformações nas relações de gênero e entre gerações compõem novo cenário social e familiar. A extensão da escolarização e dificuldades de inserção e permanência no mercado de trabalho acentuam a dependência dos jovens em relação aos pais (p. 1421).

Contudo, a adolescência vai além de um período de transição e não é uma realidade única e homogênea nas regiões e camadas sociais (UNICEF ${ }^{120}$, 2003), tão pouco contempla apenas uma direção para esse período da vida, ela é parte de um processo maior, "dependente das condições materiais objetivas e subjetivas de existência de sujeitos reais.” (PERES e col. ${ }^{87}$, p. 55, 1998). 
Desse ponto de vista, são insustentáveis os marcos conceituais que ainda se apóiam na "construção de um padrão típico", que negam "a complexidade das vivências da adolescência" (GROSSMAN ${ }^{51}$, 1997, p.8) e não atentam, por exemplo, ao fato de que o prolongamento da juventude é diferente dependendo da classe social e do gênero (GALLAND ${ }^{49}$, 1997; HEILBORN e col $\left.{ }^{57}, 2002\right)$.

De uma perspectiva sócio-histórica, a busca de acesso ao mundo adulto implica na assunção de um papel social, na construção de uma identidade e no uso do corpo, em diferentes formas e intensidades, dimensões que se dão no tempo histórico (OLIVEIRA ${ }^{80}$, 1997). São experiências que colocam o adolescente numa outra lógica, pois passa de um estado de grande dependência a um de considerável independência, o que lhe confere certo poder para explorar as diversidades do mundo, do outro e de si mesmo, transformando-as e sendo transformado.

Esse é um processo de grande ambigüidade, mas inerente às tentativas do adolescente em discriminar seu eu do mundo que o cerca e conquistar as bases para a construção do sentimento de autonomia e da capacidade de escolha de suas dependências (LEVISKY ${ }^{64}$, 2001). Na contemporaneidade, a conquista da independência pelos jovens "se coloca cada vez mais tardia, o que não impede que a autonomia seja uma aspiração cada vez mais precoce" (BRANDÃO ${ }^{19}, 2006$. p.1422). Sobremaneira, é um processo de muitas 'perdas e ganhos' e a forma como é vivenciado e elaborado é fundamental para constituir sua vida social e subjetiva.

Entre as inumeráveis situações novas vivenciadas pelos adolescentes, parece ser a possibilidade de efetivo exercício da sexualidade, em seu amplo sentido, a que adquire maior significação para a construção de si e para a mediação de suas relações sociais ${ }^{19}$ e 46 . Surge, então, a necessidade de articulação, ainda que provisoriamente, das dimensões sociais, psicológicas e biológicas.

No Brasil, no ano 2000, segundo o Censo $2000{ }^{58}$ (2007) havia cerca de 35 milhões de pessoas com idade entre 10 e 19 anos, o que correspondia a 20,8\% 
da população total. "Boa parte dessa população vive na periferia, integrando famílias de baixa renda e de baixa escolaridade" (CAVASIN ${ }^{33}$, p.11, 2004). Apesar da considerável melhoria dos indicadores sócio-econômicos e das condições de vida apontadas por BRASIL (2004) $)^{23}$ e BRASIL (2006) ${ }^{26}$, propiciar condições saudáveis de vida a esse contingente de adolescentes é um dos grandes desafios de um país em desenvolvimento. Há ainda que considerar, de igual modo, que o Brasil é um país de dimensões continentais, com grandes disparidades regionais e as características da população adolescente brasileira são tantas que se prefere "falar não em adolescência, mas em adolescências brasileiras" (p. 9) ${ }^{120}$.

Por exemplo, "as diferenças socioculturais, econômicas e outras existentes entre o modo de vida urbano e rural podem implicar em necessidades de saúde diferenciadas para adolescentes e jovens de ambos os contextos" (BRASIL ${ }^{27}$, p. 14. 2006). Com tantas disparidades, é notório que a oferta de atenção integral ao adolescente permanece precária na maioria das regiões e municípios.

Isso ocorre, malgrado o fato de existir conhecimentos e programas suficientemente elaborados e propostos no âmbito das políticas públicas que o próprio poder público, por meio de seus gestores, não tem conseguido desdobrar em propostas e intervenções territoriais. No setor saúde, mesmo em municípios relativamente desenvolvidos, raramente a população adolescente chega a constituir a justa parcela da atenção de uma unidade básica de saúde.

Aliás, parece existir a concepção de que, por, raramente adoecerem, a saúde pública pouco tem a oferecer para essa população, quando na realidade, deveria ser justamente o inverso. Parece tratar-se de uma visão reducionista e negativa das contingências possíveis da saúde dos adolescentes, pois se é verdadeiro, por um lado, que eles adoecem menos que as demais faixas etárias, requerendo, portanto, poucos serviços da assistência médica, por outro, se ignora com isso, as dimensões que se referem à promoção de qualidade de vida e prevenção de agravos à saúde. 
Quando se observa, especificamente, o acesso dos adolescentes à assistência de saúde, percebe-se ainda, que há uma grande lacuna na extensão desses serviços a eles ${ }^{27}$. A análise de prontuários nas unidades de saúde revelou que, muitas vezes, os adolescentes ficam excluídos de programas de saúde assim que, ainda na infância, deixaram de buscar o atendimento pediátrico (ROSA, 2004) ${ }^{105}$. Parece que é nesse hiato, que a menina que deixou de ser atendida aos, oito, nove ou dez anos, comparece, já adolescente, aos quatorze, quinze ou dezesseis anos, solicitando consulta médica para iniciar o pré-natal.

Embora o cenário de atenção à saúde dos adolescentes ainda seja muito precário no país, não é possível deixar de registrar alguns avanços relativos a essa população. Em parte, eles podem ser representados pela grande evolução das leis nas últimas décadas, cujo ápice, foi a criação do Estatuto da Criança e do Adolescente pela Lei $\mathrm{n}^{\circ} 8.069$, de 13 de Julho de 1990.

O ECA ${ }^{20}$ (1991) estava previsto desde 1988, no Artigo 227 da Constituição Federal Brasileira e sua elaboração significou o acolhimento pelo Brasil dos dez princípios da Declaração Universal dos Direitos da Criança, declarada pelo UNICEF, em 1959. Representou, também, um grande aperfeiçoamento do antigo Código de Menores, de 1979, e que até 1991 ainda estava em vigor.

O Estatuto da Criança e do Adolescente é um marco histórico para o país na consolidação e garantia dos direitos de cidadãos para as crianças e adolescentes, que desde então, quando negligenciados, quer sejam pelos responsáveis, pela sociedade civil ou pelo poder público, passaram a ter no Estatuto, um instrumento legal para assegurar-lhes a primazia da proteção integral. $\mathrm{O} \mathrm{ECA}^{20}$ versa que estão assegurados às crianças e adolescentes

por lei ou por outros meios, todas as oportunidades e facilidades, a fim de lhes facultar o desenvolvimento físico, mental, moral, espiritual e social, em condições de liberdade e de dignidade (..) é dever da família, da comunidade, da sociedade em geral e do poder público assegurar, com absoluta prioridade, a efetivação dos direitos referentes à vida, à saúde, à alimentação, à educação, ao esporte, ao lazer, à profissionalização, à cultura, à dignidade, ao respeito, à liberdade e à convivência familiar e comunitária (Art. $3^{\circ}$ e $\left.4^{\circ}\right)^{20}$. 
Outra parte dos avanços em relação aos direitos e deveres do adolescente decorre de pressões sociais que exigiram várias iniciativas do poder público, como criação de secretarias governamentais de atenção ao adolescente e programas federais (BRASIL $\left.{ }^{21}, 1996\right)$, estaduais e municipais voltados à criança e ao adolescente, além da criação dos Conselhos Tutelares (previsto no ECA). Também, no âmbito da sociedade civil organizada, surgiram nas últimas décadas, várias organizações que lutam pela garantia de direitos e cidadania.

Nas universidades, centros de pesquisa, comissões e grupos de trabalho se organizaram em torno da questão e pesquisas, em volume considerável, foram e estão sendo realizadas, contribuindo, inclusive, para a melhoria das políticas públicas. Há, ainda, que se registrar o advento da AIDS, fato que exigiu o desenvolvimento de meios de prevenção ao HIV, promovendo, assim, certo 'esquadrinhamento' das práticas sexuais, dando maior visibilidade à vida sexual na adolescência, o que colaborou para o avanço de discussões sobre a sexualidade juvenil (PAIVA ${ }^{83}$, 1994; PARKER ${ }^{85}$, 1994).

Contudo, apesar desse cenário promissor observado nas duas últimas décadas, ADORNO ${ }^{2}$ (2001) destaca que os adolescentes compõem um grupo muito vulnerável às situações que podem expô-los a uma condição marginal. Pode-se dizer que em contextos de vulnerabilidade (AYRES e col. ${ }^{8}, 1997$ ), as oportunidades diminuem à medida que os adolescentes não obtêm recursos para lidar com circunstâncias adversas e que podem constituir situações conflitivas, de sofrimento e agravos à saúde desnecessários.

Em meio a tantas adversidades, tem tomado maior vulto, as experiências dos adolescentes com o desamparo, o abuso de drogas (CASTRO e col. ${ }^{31}$, 2002), o conflito com a lei e a violência (VERMELLO ${ }^{123}$, 1994; ABRAMOWAY e col. ${ }^{01}$, 2004) e a infecção com o HIV 27, 83 e 85. Também a ocorrência da gravidez e da maternidade ao longo da adolescência é apontada, freqüentemente, como uma dessas situações e, conseqüentemente, desaconselhada e tomada como inoportuna nessa etapa da vida.

Aliás, a noção de "etapismo" para pensar o desenvolvimento humano 
tem sido criticada por vários autores, pois, corre-se o risco de produzir generalizações que não atentam para algumas particularidades, em especial, quando se considera a 'gravidez de adolescentes', como as de gênero, classe e etnia (BORDIEU ${ }^{17}$; CABRAL ${ }^{28}$; CASTRO e col. ${ }^{31 \text { e } 51}$; HEILBORN ${ }^{55}$, 2006).

Muitas argumentações referem que um destino precário estaria reservado à adolescente-mãe, indicando que uma gravidez aumentaria, consideravelmente, suas chances de ser mãe novamente sem planejamento, não avançar nos estudos e não inserir-se no mercado de trabalho (TAKIUT ${ }^{117}$, 2004). Segundo a Organização Mundial da Saúde, a não inserção no mercado de trabalho, diminui a renda das adolescentes e aumenta sua vulnerabilidade social (WHO $\left.{ }^{127}, 2004\right)$.

Há ainda outras situações de fragilização relacionadas à gravidez na adolescência, como o aborto provocado (PERES e col. ${ }^{88}$, 2006; ABRAMOWAY e col. ${ }^{01}$, 2004; REDE FEMINISTA DE SAÚDE ${ }^{97}$, 1998), mortalidade infantil e materna e, filhos com baixo peso ao nascer e prematuridade ${ }^{26}$. Entretanto, a respeito desses indicadores, estudos, como os realizados por MARIOTONI e col. ${ }^{69}$, (2000) indicam que não procede, a associação feita entre gravidez e baixo peso ao nascer ou prematuridade do parto, desde que as adolescentes tenham acesso aos recursos adequados. No mesmo sentido, BRASIL ${ }^{27}$ (2006) relaciona a ocorrência desses agravos à baixa escolaridade, à pobreza, à falta de acesso aos direitos sociais e à baixa qualidade da atenção obstétrica e menos aos aspectos próprios da faixa etária.

A atual exposição das adolescentes brasileiras às possíveis situações de vulnerabilidade parece não ser diferente do que outrora ocorria às 'meninasmoças'. A gravidez e a maternidade no início da segunda década da vida estão presentes na cultura brasileira desde o Brasil colonial, conforme descrevem RIBEIRO ${ }^{101}$ (1995) e FREYRE ${ }^{48}$ (2005).

É bem verdade, que há populações indígenas, africanas, asiáticas ${ }^{127}$ que, culturalmente, a vida reprodutiva inicia-se com os primeiros sinais da mocidade e, conseqüentemente, se instala o processo reprodutivo com um ou vários filhos em um curto período de tempo, não acarretando, aparentemente, 
prejuízos à adolescente e ao seu meio social. Ao contrário, a maternidade nesses casos, parece produzir inúmeras satisfações às jovens e à comunidade.

No caso da população brasileira, não se pode negar que ela é formada a partir de uma heterogeneidade muito grande de etnias e culturas 101 e 48 e que, provavelmente, as matrizes culturais estão presentes orientando a cultura sexual e reprodutiva da população. Entretanto, a naturalidade com que, vez e outra, se reportam leigamente à gravidez e a maternidade de nossas antepassadas como algo comum e 'normal', parece esconder as situações de inferioridade e violência às quais as mulheres foram submetidas ao longo do tempo em nossa cultura e tratadas tão simplesmente como "ventres geradores" (REIS e col. ${ }^{100}, 1993$ ). Essas condições foram naturalizadas dentro do "machismo dominante", inclusive, na iniciação sexual/reprodutiva ${ }^{33}$.

Parece também, que ao longo da história brasileira, a iniciação sexual das jovens se deu em contextos nos quais possuíam pouco ou nenhum controle sobre seus corpos (PARKER ${ }^{86}, 1991$ ). A naturalização da violência contra as mulheres oculta ainda como que o

catolicismo e a visão médico-científica da vida sexual que apareceu no fim do século 19 colocou-se inicialmente na ênfase da norma da reprodução sexual (..) o casal conjugal tornou-se centro da noção de expressão sexual legítima ${ }^{86}$ (p.131).

Dessa forma, parece, que primeiro se inventou a 'mãe-solteira', assim como se inventaram outras categorias que foram tomadas como perversões sexuais pela moral sexual vigente no século XIX e início do século XX, que atentavam contra a moral religiosa e o casamento. Décadas depois, inventou-se a 'adolescente grávida', que afronta a biologia e a lógica do mercado, idéia bem expressa pelo conceito de gravidez precoce. Em tese, representam a mesma coisa, muito embora, a segunda conceituação tenha uma roupagem nova e é referendada por um marcador cronobiológico.

Não é mais a religião, mas a medicina que ajuíza, não é mais a construção de uma identidade nacional católica que está em pauta, mas a 
formação de trabalhadoras e consumidoras. É desde então, que a gravidez na adolescência, passou a ser observada com alarde.

O reflexo dessas concepções são as políticas preventivistas ${ }^{51}$, ainda hoje, impregnadas nos programas de atenção aos adolescentes. Nas suas entrelinhas, apregoam que as meninas devem ser 'bem comportadas', 'estudadas', 'casadas' e finalmente, 'serem mães' - talvez com um acréscimo nas últimas décadas, precisam 'inserirem-se no mercado de trabalho', como se esse fosse justo.

Ainda, na linha das políticas preventivistas, também os estudos sobre a gravidez e a maternidade de adolescentes têm-se pautado, predominantemente, por análises e explicações situadas em três discursos, o biomédico, o psicológico e o dos riscos psicossociais (HEILBORN e col. ${ }^{57}$, 2002). Esses discursos, geralmente, colaboraram para criar pré-concepções sobre as adolescentes, seus corpos e os usos que dele se faz, situando o exercício da vida sexual como 'um problema' e não como expressão de um intrincado cenário constituído por

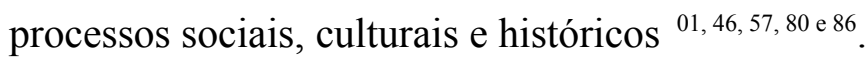

Entretanto, considerando o cenário do modus de vida contemporâneo, não se pode negar que a gravidez e a maternidade que ocorrem durante a adolescência têm se mostrado como fenômeno complexo que pode afetar a trajetória de vida das jovens, tornando-as menos autônomas e mais vulneráveis. Geralmente, a gravidez e a maternidade parecem atuar de maneira a diminuir, para as adolescentes, suas oportunidades de 'empoderamento' e de garantia de direitos, especialmente quando pobres. (YAZAKI e col ${ }^{128}$, 1998; BERQUÓ ${ }^{11}$, 2003).

A todo o momento, os dados reiteram que a gravidez e a maternidade na adolescência estão influenciadas pelas expectativas de vida que a adolescente pode ter em determinadas condições sociais, econômicas, culturais, históricas e subjetivas. Aliás, é isso que faz dela um campo relevante de estudo para a saúde pública. 
A postura preventivista, é compreensível, tira de foco e parece proteger a todos da periclitante questão: que escolhas os adolescentes devem e podem fazer? Esse campo ainda é uma celeuma e é guiado praticamente apenas pelos costumes e pela moral. O próprio Estatuto da Criança e do Adolescente "não especifica os direitos em relação ao exercício da sexualidade, quando o que está implícito é a possibilidade de os jovens decidirem sobre sua vida sexual e reprodutiva" ${ }^{33}(\mathrm{p} .03)$.

Não é de estranhar, portanto, os motivos pelos quais as reflexões sobre a gravidez e a maternidade de adolescentes e, em decorrência, as propostas de atenção ao exercício da sexualidade pelos adolescentes estejam inscritas numa certa pedagogia médica. Em última instância, parece ser essa a mesma que defende, por um lado, a abstinência sexual pré-marital - como se o destino fosse o casamento - e, por outro, a esterilização e o controle da natalidade dos pobres.

$\mathrm{Na}$ esteira de controles, não é de estranhar a pesquisa inédita coordenada por DUARTE ${ }^{42}$ (2006) no município de Porto Alegre-RS e que está implantando cápsulas de anticoncepcional em 2500 jovens. Isso parece abrir um precedente para implantes de anticoncepcionais em adolescentes em larga escala no Brasil sem que se tenha garantido a essa população as condições para que possam escolher autonomamente por um ou outro método contraceptivo.

REIS ${ }^{99}$ (1998), ao estudar como a gravidez de adolescentes foi tomada como objeto da saúde pública, verificou um crescente número de escritos médicos sobre a questão a partir da década de 40, especialmente no pós Guerra, período em que houve um considerável aumento da população jovem e, conseqüentemente, de adolescentes grávidas. Entretanto, na

expansão geocultural dos textos sobre adolescentes grávidas, não se verificou nenhuma diversificação teórica ou enriquecimento de pontos de vistas epistemológicos ou disciplinares. Estes estudos e pesquisas aglutinaram-se quase que exclusivamente em torno de um eixo de considerações obstétrico-pediátricas ${ }^{99}$ (p.118).

REIS 99 esclarece ainda que, na década de 60, o padrão de comportamento sexual ocidental foi, sobremaneira, influenciado (1) pelos 
movimentos juvenis que questionavam os padrões propostos; (2) pelo feminismo, que questionou os papéis sociais atribuídos ao masculino e feminino e (3) pelo surgimento dos métodos contraceptivos que permitiram o exercício da sexualidade independentemente da maternidade. Contudo,

foram os trabalhos norte-americanos e, muito secundariamente, os ingleses que passaram a contemplar significativamente outras áreas do conhecimento, tais como educação, saúde pública e psicologia, demonstrando uma superação da problemática biomédica ${ }^{99}$ (p. 18).

Entretanto, temos uma porção de ferramentas conceituais que são heranças do iluminismo e do modelo biomédico que, ainda hoje, doutrinam a produção de conhecimento e prestação de serviços aos adolescentes ${ }^{51}$. Dessa visão decorrem alguns adjetivos dados ao fenômeno como 'gravidez precoce', 'gravidez não planejada' e 'gravidez indesejada' (LIMA e col $\left.{ }^{65}, 2004\right)$.

Essas expressões funcionam como princípios ou matrizes teóricas, que, como crenças silenciosas, condicionam e limitam a problematização do tema. LIMA e col. ${ }^{65}$ referem que, geralmente, na abordagem da gravidez na adolescência, recorre-se a esses três qualificativos porque se consideram, nesse modelo explicativo, as noções de oportunidade, adequação, previsão e desejabilidade do evento.

O primeiro qualificativo, 'gravidez precoce', pressupõe uma idade mais adequada para ter filhos e a existência de uma oportunidade ótima de maturidade física e psicológica. Há, portanto, um pressuposto cronobiológico como condição reprodutiva ideal, que desconsidera as diferenças individuais, étnicas, sociais, culturais e de gênero ${ }^{65,51}$.

O outro qualificativo, 'gravidez não-planejada', decorre da consideração por algumas concepções de que os adolescentes devem ser capazes de se responsabilizarem por seus atos. Apregoa-se que isso deve ocorrer a partir de um projeto racional de vida e no qual a reprodução acontecerá apenas quando outras condições de vida forem conquistadas, como a escolarização e a profissionalização ${ }^{65,51}$. 
Conforme os autores ${ }^{65}$, na concepção de 'gravidez não planejada' acredita-se que a gravidez ocorrida ao longo da adolescência é decorrente de um descuido, por omissão, inabilidade ou problema no uso de contraceptivos, e exigese, portanto, do adolescente, a "antevisão do risco associado ao exercício da vida sexual" (p.72).

Esse qualificativo pressupõe, portanto, que a adolescente deve ter um domínio técnico suficiente para o planejamento reprodutivo, suposição essa, que não considera as demais dimensões envolvidas nas práticas sexuais ${ }^{65}$. Parece tratar-se nessa concepção de um desejo técnico e externo à adolescente em que se tenta exigir dele o planejamento reprodutivo. Entretanto, garantir informações e condições de acesso a anticoncepcionais não tem sido suficiente, embora necessário.

VARELLA $^{121}$ (2004) relaciona a falta de planejamento familiar como uma das causas mais importantes da explosão da violência urbana ocorrida nos últimos 20 anos no Brasil e que a ausência desse planejamento impede a diminuição das desigualdades. Diz o autor: "É difícil achar na cadeia um preso criado por pai e mãe. A maioria é fruto de lares desfeitos ou que nunca chegaram a constituir-se. O número daqueles que têm muitos irmãos, dos que não conheceram o pai e dos que foram concebidos por mães solteiras, ainda adolescentes, é impressionante" ${ }^{121}$ (p. E8).

Não podemos partilhar do mesmo raciocínio de VARELLA ${ }^{121}$, pois parece que o autor toma os efeitos da violência e de outros contextos como a causa da violência, o que não é verdadeiro. Entretanto, é um autor que tem o privilégio de dar visibilidade às suas idéias na grande mídia de maneira muito incisiva e com o 'respaldo da ciência'. Parece-nos que está formando opiniões junto à população que podem ser parciais e que não contribuem para o efetivo debate da questão.

MIRÓ $^{72}$ (2004), afirma que o controle da natalidade foi o evangelho que os norte-americanos distribuíram para a América Latina como forma de crescimento econômico. "No entanto, as taxas de natalidade diminuíram, mas a desigualdade ainda persiste" ${ }^{72}$ (p. E8). Assim, não é de estranhar, a presença da 
"moral utilitarista" 122 em alguns organismos internacionais.

CABRAL ${ }^{28}$ classifica de enfoques "tradicionais", campos de estudos situados em campos sócio-demográficos e médico-epidemiológicos que operam reduções de fenômenos complexos à simples relações de causa e efeito, como, por exemplo, a que relaciona gravidez ocorrida durante a adolescência à reprodução intergeracional da pobreza.

Finalmente, o terceiro qualificativo, 'gravidez indesejada', pressupõe a existência de uma clara consciência acerca da possibilidade da gravidez no exercício da sexualidade e da constituição de razões suficientemente fortes para impedir sua consecução em nome de outros objetivos. Nesses termos, conforme os autores ${ }^{65}$, na concepção de 'gravidez não desejada', haveria para a adolescente grávida, uma contrariedade às suas aspirações para aquele momento de sua vida.

Considerando essas três concepções não parece que seja possível afirmar que uma delas explica melhor a gravidez e a maternidade de adolescentes. Ao contrário, é bem possível que as três dimensões interajam em favor de demandas individuais em determinados contextos e condições de vida e favoreçam ou não a ocorrência da gravidez e consequentemente, a maternidade ao longo da adolescência.

Procurando investigar esses aspectos, CABRAL ${ }^{28}$ (2002) perguntouse: "Será a gravidez na adolescência um 'problema' de classe ou de geração?" HEILBORN ${ }^{52}$ (1991) e AQUINO e col. ${ }^{05}$ (2003) questionaram: "Não seriam as questões de gênero". DADOORIAN ${ }^{40}$ (2000) indagou: "Por que as adolescentes querem engravidar?” (p.28). CARVALHO ${ }^{30}$ (2007), por sua vez, interrogou: "Qual o significado que pode ter o corpo para adolescentes grávidas que vivem em situação de pobreza crônica?"

Também nos perguntamos: Será a gravidez/maternidade apenas conseqüência do exercício da vida sexual sem planejamento? Das condições de vida? Da densidade demográfica? Dos contextos de vulnerabilidade? Será a maternidade na adolescência uma possibilidade existencial? Um fenômeno relacionado ao desenvolvimento psicossexual? Adolescentes que têm dois ou mais 
filhos durante a adolescência vivenciam a maternidade de forma diferente daquelas que tiveram apenas um?

Foram muitas perguntas ao vento até que uma soprou mais forte: As maternidades sucessivas na adolescência é um fenômeno diferente ao da gravidez na adolescência?

Derivou dessa questão, com a finalidade de apreender a concretude histórico-social desse fenômeno num determinado contexto, outro questionamento: Como se caracterizam os contextos reprodutivos, sócioeconômicos e individuais presentes em adolescentes, com idade entre 15 e 19 anos, residentes em Rondonópolis-MT, que deram a luz a pelo menos um filho nascido vivo e estão grávidas novamente? 


\section{2 - A GRAVIDEZ E A MATERNIDADE EM ADOLESCENTES}

Segundo a Organização Mundial de Saúde ${ }^{125}$, gravidez durante a adolescência é "aquela que ocorre até os 20 anos incompletos". Embora qualquer recorte cronológico sobre início e fim da adolescência esconda a diversidade com que ela se apresenta para cada indivíduo ${ }^{51}$, a Organização Mundial de Saúde ${ }^{127}$ definiu-a como a faixa etária compreendida entre 10 e 19 anos.

Entretanto, a própria Organização Mundial da Saúde, ciente das diferenças presentes em tão longo período, subdividiu-a em duas faixas etárias: dos 10 aos 14 anos e dos 15 aos 19 anos completos. No Brasil, o Sistema de Informações de Nascido Vivos ${ }^{25}$ (SINASC) utiliza os mesmos critérios, mas nomeia a primeira de 'menores de 15 anos'.

O ECA considera a adolescência, a faixa etária compreendida entre os 12 e $18 \operatorname{anos}^{20}$. O instituto de pesquisa SEADE (Fundação Sistema Estadual de Análise de Dados - SP) e a CNPD (Comissão Nacional de População e Desenvolvimento) adotam em seus estudos a faixa etária de 10 a 19 anos como adolescência e de 15 a 24 anos como juventude.

A respeito da faixa etária que caracteriza a 'juventude', a Organização Mundial da Saúde ${ }^{127}$ criou uma grande categoria chamada de população jovem, que se estende dos 10 aos 24 anos de idade e numa outra categoria, diferenciou 'adolescência' de 'juventude', essa última compreendendo a faixa etária dos 15 aos 24 anos.

Segundo a Organização Mundial da Saúde ${ }^{126}$, nas últimas décadas a gravidez de adolescentes tornou-se um problema para muitos países desenvolvidos e em desenvolvimento, mas salienta que esse não é um fenômeno novo. Há regiões do mundo, como no sul da Ásia, meio oeste e norte da África, onde, tradicionalmente, as mulheres se casam e têm filhos tão logo menstruam e, o fato, não é considerado um problema, contrariamente, ao que ocorreu nos séculos XIX e XX, na Europa, em que a idade para o casamento era mais avançada e a vida sexual antes e fora do casamento era desencorajada. 
$\mathrm{Na}$ dinâmica da população brasileira, a ocorrência em grandes proporções de gravidez/maternidade em adolescentes, até onde se tem registro, foi um fenômeno típico das décadas 80 e 90 e articulado às transformações dos padrões sexuais vigentes, como a diminuição do valor da virgindade para o casamento e a antecipação da iniciação sexual (SANTINI DE ALMEIDA, 2002) 108 , do questionamento da noção de casamento e dos usos que se pode fazer do corpo e de seus prazeres ${ }^{86}$.

Segundo o relatório SAÚDE BRASIL 2004 (2004) ${ }^{23}$ o aumento ocorreu justamente num período em que a taxa de fecundidade total brasileira esteve em considerável queda, com redução de 57\% no período 1970/2000. Em 1970, o país tinha uma taxa de fecundidade total de 5,8 filhos por mulher. Em 1980, diminuiu para 4,4 e em 1991, o índice situou-se em 2,8.

No ano 2000, o indíce ${ }^{\mathrm{I}}$ diminuiu ainda mais e assinalou apenas 2,3 filhos por mulher ${ }^{23}$. Segundo BERQUÓ e col ${ }^{14}$ (2006), em 2004 atingiu 2,1. Essa taxa de fecundidade total mal repõe a população, apontando para um acelerado envelhecimento populacional, caracterizando o que os demógrafos chamam de 'transição demográfica'.

Segundo o relatório Saúde Brasil $2004^{23}$, em 1980, a fecundidade das mulheres de 15 a 19 anos de idade representava $9,1 \%$ da fecundidade total do país. Em 2000, esse percentual aumentou para 19,4\% e em 2001, subiu para $22,4 \%$. Foi a única faixa etária que apresentou, no período, aumento da taxa específica de fecundidade. Diferentemente do ocorrido no Brasil, conforme vários

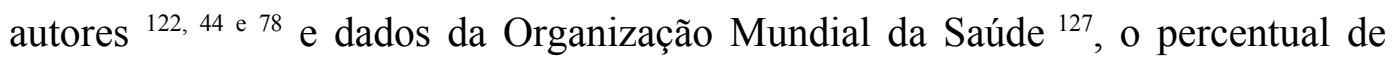
ocorrência de gravidezes e maternidades em adolescentes é consideravelmente menor nos países desenvolvidos ${ }^{\mathrm{II}}$.

Contudo, após duas décadas de progressivo aumento do percentual de nascidos vivos filhos em adolescentes de 15 a 19 em relação ao total de nascidos vivos no restante da população, nos últimos anos iniciou-se uma tendência de

\footnotetext{
${ }^{\text {I }}$ Para o ano 2050, as estimativas das Nações Unidas é que atinja 1,83 filhos por mulher no Brasil.

${ }^{\text {II }}$ Nos EUA, em 1988 chegou a 12,5\% ${ }^{122}$. Na França, em 1981 foi de 6\% e em 1995, 2,4\% ${ }^{44}$. Na Suécia, em 1997, não chegou a $3 \%{ }^{78}$. Em 1998, no Japão, atingiu $1 \%$ e na Nigéria, $53 \%{ }^{3}$.
} 
diminuição desses nascimentos. O relatório SAÚDE BRASIL $2005{ }^{24}$ (2005) indica que a partir de 2002, caiu para 21,8\% (665.437 nascidos vivos) e a 21,3\% em 2003 (645.806 nascidos vivos) o percentual de nascidos vivos, filhos de adolescentes de 15 a 19 anos. Dados mais recentes do relatório SAÚDE BRASIL $2006^{26}$ (2006), indicam que em 2004, reduziu ainda mais o percentual, caindo para $21,0 \%$, o que equivaleu a 635.014 nascidos vivos entre adolescentes de 15 a 19 anos.

Em 2003, todos os Estados brasileiros apresentaram percentuais de nascidos vivos filhos de mães adolescentes de 15 a 19 anos abaixo do registrado em 2002. O Maranhão apresentou a maior proporção, cerca de 29,9\%. Já os menores percentuais foram encontrados no Distrito federal (16,9\%), São Paulo $(17,4 \%)$ e Minas Gerais (18,7\%). Entre os Estados da região Norte, Tocantins é o que apresentou o maior percentual, 30,4\%. Na região Sul, o Paraná é o Estado com maior percentual. Na região Centro-oeste, destacou-se o Estado do Mato Grosso, com cerca de $26,7 \%{ }^{24}$.

Há certo otimismo por parte dos gestores governamentais com a diminuição dos percentuais de gravidezes na adolescência. Estudo referente ao Estado de São Paulo, com dados da Secretaria Estadual de Saúde, realizado por TAKIUTI ${ }^{118}$ (2005), demonstram que, se em 1998, 20\% dos partos ocorriam em adolescentes (10 a 19 anos), em 2004, o percentual diminuiu para 17\%. Em sete anos, a queda foi de $27,9 \%$, caiu de 148.000 partos para 106.700 .

Também BERQUÓ e col. ${ }^{15}$ (2005) apresentam dados referentes ao país que revelam a inversão da tendência de aumento da ocorrência de gravidez e maternidade em adolescentes, registrando em 2003, índices menores que aqueles registrados na década anterior.

em 2003, conforme dados da Pnad, havia 81 mulheres grávidas para cada grupo de 1000 adolescentes entre 15 e 19 anos. Em 1999, quando foi verificado o pico desse fenômeno, a taxa era de 90,5 por 1000 . A queda de $10,55 \%$ nesse período levou o indicador a apresentar em 2003 uma taxa inferior à constatada em 1992, quando ficou em 84,6 por $1000^{15}$ (c2).

As pesquisadoras ${ }^{15}$ apresentam também dados do Registro Civil e do 
SINASC que apontam para a mesma tendência, o que parece assinalar a inauguração de um novo período da dinâmica reprodutiva da população brasileira. Os dados da PNAD 2004 confirmaram essa tendência e revelaram que a diminuição da fecundidade total entre 1991 e 2004 foi produzida, principalmente, pela redução da fecundidade entre as mulheres mais pobres e com menos escolaridade (BERQUÓ e col., 2006) ${ }^{14}$.

No que se refere às possíveis causas de gravidez e maternidade durante a adolescência, estudos apontam que há estreita relação entre gravidez/maternidade na adolescência, contexto sócio-cultural-histórico e indicadores da qualidade de vida de cada região (ABRAMOWAY e col. ${ }^{01}$; BERQUÓ $\left.{ }^{13}, 2003\right)$.

Há áreas urbanas em que o total de partos em mulheres abaixo dos 20 anos chega a $42 \%$, entre as mais pobres, e a $44 \%$ entre aquelas com menor escolaridade ${ }^{01}$. Entretanto, se por um lado é verdadeiro que baixa renda e pouca escolaridade estão relacionadas ao aumento da proporção de gravidezes e maternidades de adolescentes, por outro lado, estudos realizados por MONTEIRO ${ }^{73}$ (2004) e BERQUÓ e col. ${ }^{15}$, indicam que também aumentou a proporção de filhos nascidos vivos (FNV) nos últimos anos entre as adolescentes com maior poder aquisitivo e escolaridade. Há indícios, portanto, que existem determinantes para a gravidez durante a adolescência que vão além da condição econômica.

Quanto à escolaridade, PIROTTA e col. ${ }^{93}$ (2004) encontraram que quanto maior a escolaridade, menor o número de adolescentes grávidas ou mães. Constataram também que universitários paulistas adiavam a gravidez, a maternidade e/ou a paternidade em função de um projeto de vida orientado para a conclusão de um curso superior e a inserção no mercado de trabalho, diferentemente dos jovens que não se pautam por esses valores e objetivos.

HEILBORN e col. ${ }^{56}$ (2000) apresentam dados que indicam o mesmo fato. A proporção de gravidezes ao longo da adolescência varia inversamente à escolaridade. Das jovens grávidas até os 20 anos, 59,3\% havia completado apenas 
o primeiro grau, enquanto que entre universitárias, o percentual foi de apenas $4,6 \%$.

Temos, portanto, que há adolescentes grávidas em que baixa escolaridade é decorrente da evasão escolar. Isso parece agravar o cenário de vulnerabilidades. Entretanto, se a baixa escolaridade e a evasão escolar caracterizam uma situação de alta vulnerabilidade à gravidez e maternidade na adolescência, há que destacar que muitas adolescentes abandonam a escola justamente por causa da gravidez/maternidade, em parte, devido à nova realidade e, em outra, por que as escolas não estão preparadas para receberem estudantesadolescentes.

Nesses termos, a pouca escolaridade e evasão escolar, deixam de ser causa para a gravidez de adolescentes e passam a ser conseqüências. Nesse sentido, SAÚDE BRASIL $2006{ }^{26}$ não utiliza mais a categoria 'escolaridade' no cruzamento das informações relativas à gravidez em menores de 15 anos, "pois expressa muito mais a idade das meninas do que de fato o nível sócio-econômico, o acesso a serviços ou a informação" (p.323)

HEILBORN ${ }^{53}$ (1997) encontrou dados, que revelam que a maternidade na adolescência tem um efeito considerável na vida escolar das jovens. No primeiro ano após o parto, 42\% confirmaram dificuldades para freqüentar a escola, $25 \%$ deixaram de estudar temporariamente e 17\%, definitivamente. ABRAMOWAY e col. ${ }^{01}$ encontraram dados parecidos em pesquisa realizada em 14 capitais, uma em cada quatro meninas, entre 15 e 17 anos que abandonam a escola, refere que a gravidez foi o principal motivo.

Outros autores ${ }^{70}$ e 128 , ao considerarem a dinâmica reprodutiva da população brasileira durante as décadas de 80 e 90, apontam como motivo do crescimento da ocorrência de gravidez/maternidade em adolescentes naquela época, o rejuvenescimento da fecundidade no Brasil. A esse respeito, BERQUÓ e col. ${ }^{13}$ (2003) esclarecem que

Em 1980, o peso da fecundidade das jovens de 15 a 19 anos, no universo da fecundidade total, era de $9 \%$. Em 1991, esse peso passou para $14 \%$. E, em 2000 , chegou a $20 \%$. Então, se o peso do grupo 
mais jovem cresce dentro da fecundidade total, significa que nós estamos rejuvenescendo a fecundidade. Isso porque, no grupo de 20 a 34 anos, o peso da fecundidade permaneceu inalterado em $70 \%$, de 1980 a 2000. Portanto, esse grupo, que é o maior, continua com o mesmo peso na pirâmide. Já o grupo de 35 anos ou mais, que representava $21 \%$ do total da fecundidade em 1980, passa a representar 16\%, em 1991, e $12 \%$ em $2000{ }^{13}$ (p. 05).

Trata-se, portanto, de um fenômeno reprodutivo caracterizado pela concentração da fecundidade num intervalo mais curto da vida reprodutiva das mulheres e localizada no início da vida adulta. Segundo os autores, a antecipação da vida reprodutiva foi favorecida pelo baixo nível de escolaridade e pelo não uso de métodos contraceptivos.

Outra explicação que se aproxima da antecipação da fecundidade é a que trata da antecipação da iniciação sexual dos adolescentes, observada por vários autores ao longo das últimas décadas. SCHOR ${ }^{109}$ (1995) ao realizar um estudo, em 1992, na zona sul do município de São Paulo, com adolescentes do sexo feminino, de 15 a 19 anos, identificou que a idade mediana de iniciação sexual era de 16 anos.

A propósito da idade de iniciação sexual, um levantamento realizado pelo Ministério da Saúde ${ }^{26}$ (2000) constatou que em 1984, a iniciação sexual deuse entre as mulheres, em média, aos 16 anos e, em 1998, aos 15 anos. De outro modo, dados de pesquisa realizada por MELO e col. ${ }^{70}$ indicam que no Brasil, em 1986, 38,5\% das jovens iniciavam a vida sexual antes dos 18 anos e em 1996, esse percentual subiu para $56,4 \%$.

RUA e col. ${ }^{106}$ (2001), por sua vez, em pesquisa realizada em escolas de várias capitais brasileiras, destaca que

a idade média da primeira relação sexual é significativamente mais baixa entre os alunos do sexo masculino do que entre as estudantes do sexo feminino. No caso das meninas, em Porto Alegre, Manaus e São Paulo encontram-se as mais baixas idades médias da primeira relação sexual (15, 15,1 e 15,2 anos), ficando as mais elevadas em Belém e Fortaleza (16 e 15,8 anos). Quanto aos rapazes, registram-se em Cuiabá, Manaus e Salvador a mais baixa média da primeira relação sexual (13,9 anos), ocorrendo em Florianópolis a mais alta $(14,5$ anos $){ }^{106}$ (p.143). 
De forma semelhante, PIROTTA 94 (2002), em pesquisa com universitários paulistas de 18 a 24 anos, apurou que entre os alunos do sexo masculino, a idade média de início da vida sexual estava em torno dos 17 anos e nos alunos do sexo feminino, em torno dos 18 anos. Também ALMEIDA e col. ${ }^{04}$ (2003), ao realizar um estudo no Estado da Bahia, com adolescentes de 11 a 19 anos, de ambos os sexos, encontraram que a idade mediana de iniciação sexual dos meninos estava em torno dos 13 anos e para as meninas, em torno dos 15 anos.

Já AQUINO e col. ${ }^{05}$ (2003) observaram que a média da idade de iniciação sexual estava situada em 16,2 anos para os garotos e 17,9 anos para as moças. Média de idade consideravelmente mais baixa de iniciação sexual de mulheres foi encontrada por BORGES ${ }^{18}$ (2004), 14,9 anos.

Esse conjunto de dados leva a concluir que há uma diversidade de contextos que permeiam e podem influenciar a idade de iniciação sexual e, obviamente, que quanto menor a idade desse início, maiores as chances de gravidez e maternidade, se não houver uso correto de contraceptivos. Também é claro, que quanto maior a idade da jovem que não se iniciou sexualmente, maiores as possibilidades de iniciar-se ${ }^{18}$.

Contudo, não parece possível apontar conclusões a respeito de significativa antecipação da iniciação sexual como um fenômeno geral da dinâmica populacional brasileira. Parece razoável considerar que algumas populações, em determinadas circunstâncias estão se iniciando sexualmente mais cedo do que iniciavam a algumas décadas atrás. A esse respeito, a OMS ${ }^{127}$ aponta a iniciação sexual como evento chave para compreensão do aumento da gravidez na adolescência nos países desenvolvidos e a diminuição de 2 a 3 meses a cada década da idade da menarca.

Apesar da preocupação quanto à idade de iniciação sexual trazida por alguns trabalhos, há indicativos que a discussão é superada por outros fatores que influenciam mais diretamente a iniciação sexual. BORGES ${ }^{18}(2004)$, em pesquisa 
realizada sobre a vida afetivo-amorosa de jovens num bairro do município de São Paulo, diz que o

fator mais intensamente associado à iniciação sexual dos adolescentes de 15 a 19 anos foi a relação de namoro. Independentemente do sexo do entrevistado, ter namorado alguma vez anteriormente, ou estar namorando, foram associados positivamente à iniciação sexual (...) o namoro foi também referido pelos adolescentes como o contexto idealizado para a primeira relação sexual ${ }^{18}$ (p.111).

HEILBORN e col. ${ }^{56}$ no estudo multicêntrico em três capitais brasileiras, Salvador, Rio de Janeiro e Porto Alegre, corroboram os dados encontrados em São Paulo por BORGES ${ }^{18}$ e acrescentam que apenas 2,5\% das jovens engravidaram em relações que não se estendiam no tempo. Dizem as autoras ${ }^{56}$, que à medida que os relacionamentos se consolidam e adquirem alguma estabilidade, há uma tendência de relaxamento do uso de práticas de proteção e, conseqüentemente, culmina na gravidez, além do risco de infecção com alguma doença sexualmente transmissível.

Tem-se então, que as vivências afetivas e experimentações que os adolescentes realizam são mais importantes que a idade cronológica e, talvez isso explique, a relativa variedade de idades de iniciação sexual. Como tais vivências e experimentações ocorrem na presença de outrem, surge outro aspecto motivador da iniciação sexual. São intensas as influências dos pares sobre o comportamento individual para a iniciação sexual, conforme apontam estudos de ROMER e col. ${ }^{104}$, MOTT e col. ${ }^{76}$, WERNER-WILSON ${ }^{124}$ e KINSMAN e col. ${ }^{62}$.

Nesse contexto, merece destaque também, outra modalidade de relacionamento surgido nas últimas décadas, 'o ficar'. De certa forma, é uma das etapas da iniciação sexual. ABRAMOWAY e col. ${ }^{01}$ relatam que

nos discursos dos jovens o ficar configura-se, de certa forma, como uma interação afetiva e sexual onde se pode lidar com as demandas referentes às relações de namoro, consideradas mais rígidas. Neste sentido, o ficar aparece como uma alternativa ao namorar, cujos aspectos mais enfatizados por rapazes e moças, dizem respeito ao relaxamento dos acordos mais complexos, pertinentes aos relacionamentos estáveis ${ }^{01}$ (p. 88). 
Há que considerar também que os contextos de iniciação sexual ainda envolvem uma questão de gênero, persistindo para as mulheres uma "idéia não apenas romântica sobre a iniciação sexual, mas também de entrega", conforme concluiu BORGES ${ }^{18}$ (p.111) e outros autores (RIETH 102; HEILBORN ${ }^{54}$; PANTOJA $^{84}$ ). Aliás, a forte presença das delimitações entre masculino e feminino na cultura sexual brasileira é um dos principais entraves para a negociação de meios de proteção no momento da relação sexual, o que muitas vezes, coloca a mulher em situação de maior vulnerabilidade.

Uma das conclusões da GRAVAD (Gravidez na Adolescência), pesquisa coordenada por HEILBORN ${ }^{56}$ (2000) foi que são os valores de gênero, muito mais do que aqueles de classe social, que ditam normas de comportamentos para o masculino e feminino e esses, pouco se alteraram nas últimas décadas. Há ainda, diz a autora ${ }^{56}$, uma noção de que a sexualidade é de domínio masculino.

Outro importante estudo a ser considerado na análise da iniciação sexual e da gravidez/maternidade na faixa etária dos 10 aos 14 anos é o que foi realizado por CAVASIN ${ }^{33}$ em cinco capitais brasileiras. Nele, são apontados dados preocupantes que revelam que o abuso sexual está presente, desde o espaço doméstico, na iniciação sexual de muitas adolescentes. ABRAMOWAY e col. ${ }^{01}$ destacam que o assédio sexual, ocorre até mesmo, no ambiente escolar.

CAVASIN ${ }^{33}$ acrescenta que permanece sem visibilidade e subnotificada esse tipo de violência por que há intimidações de toda ordem sobre a adolescente. Geralmente, até por causa da pouca idade, as adolescentes não conhecem meios para denunciar e nem sabem ou têm a quem recorrer. Há ainda o agravante de que, muitas vezes, essas mulheres estão em total dependência afetiva e financeira do agressor. Para elas, a gravidez será a primeira oportunidade de denúncia.

Partindo de outro ponto de vista acerca da ocorrência da gravidez e maternidade na adolescência, estudos realizados por DADOORIAN $39-41$, PANTOJA ${ }^{84}$ e CARVALHO ${ }^{30}$ (2007) apontam que nem sempre a gravidez está associada a um 'imprevisto', como se fosse uma 'surpresa desagradável'. Ao 
contrário, a gravidez e maternidade na adolescência podem associar-se à realização de algum projeto pela adolescente, uma espécie de permissão para entrada na vida dos adultos, envolvendo dimensões complexas e que se ligam à mudança de "status social e de reafirmação de projetos de mobilidade social" ${ }^{84}$.

DADOORIAN ${ }^{39-41}$ esclarece que a gravidez em adolescentes pode ser decorrente do próprio desejo da adolescente de ter um filho, respondendo assim, a uma demanda particular, principalmente, por que a função social feminina na cultura contemporânea está vinculada à maternidade. Estudos, como o do antropólogo RAYNAUT ${ }^{96}$ (2002), indicam que as pessoas não ficam passivas frente às adversidades. Diz o autor, que

as populações não são objetos passivos das desigualdades. Elas buscam respostas, desenvolvem estratégias. Permanecem como atores sociais mobilizando os recursos materiais e sociais disponíveis para resolver os problemas encontrados ${ }^{96}$ (p. 53).

Nesse sentido, CARVALHO ${ }^{30}$, em pesquisa realizada numa favela de São Paulo-SP com adolescentes grávidas em situação de "pobreza crônica", encontrou que essas jovens não consideram suas gravidezes um problema social ou de saúde, mas pelo contrário, relacionam a gravidez ao desejo de serem visíveis e ativas na vida social. A gravidez ao longo da adolescência seria então uma das possíveis soluções encontradas por adolescentes frente às adversidades das condições de vida colocadas na contemporaneidade. 


\section{3 - MATERNIDADES SUCESSIVAS NA ADOLESCÊNCIA}

Para além das possíveis razões do considerável crescimento dos percentuais de gravidezes e maternidades na adolescência nas décadas de 1980 e 1990 e para sua tendência de diminuição no período 2000/2006 ${ }^{15}$ e 121 , um fato novo na dinâmica populacional do país vem despertando interesse, as adolescentes que são mães de vários filhos nascidos vivos.

Por exemplo, os dados da Secretaria Estadual de Saúde do Estado de São Paulo, apresentados por TAKIUT 117 e 118 apontam que a diminuição dos percentuais de filhos nascidos vivos em adolescentes iniciou-se no Estado de São Paulo um pouco antes que no restante do país, em 1998. Entretanto, desde então, a diminuição sempre se referiu à queda do número de "primeiros filhos nascidos vivos" de adolescentes, não se verificando redução alguma no percentual de nascimentos entre aquelas que tinham mais de um filho. Ao contrário, a proporção dessas maternidades aumentou 3,5\% no período 1998/2002, conforme ilustra o gráfico abaixo.

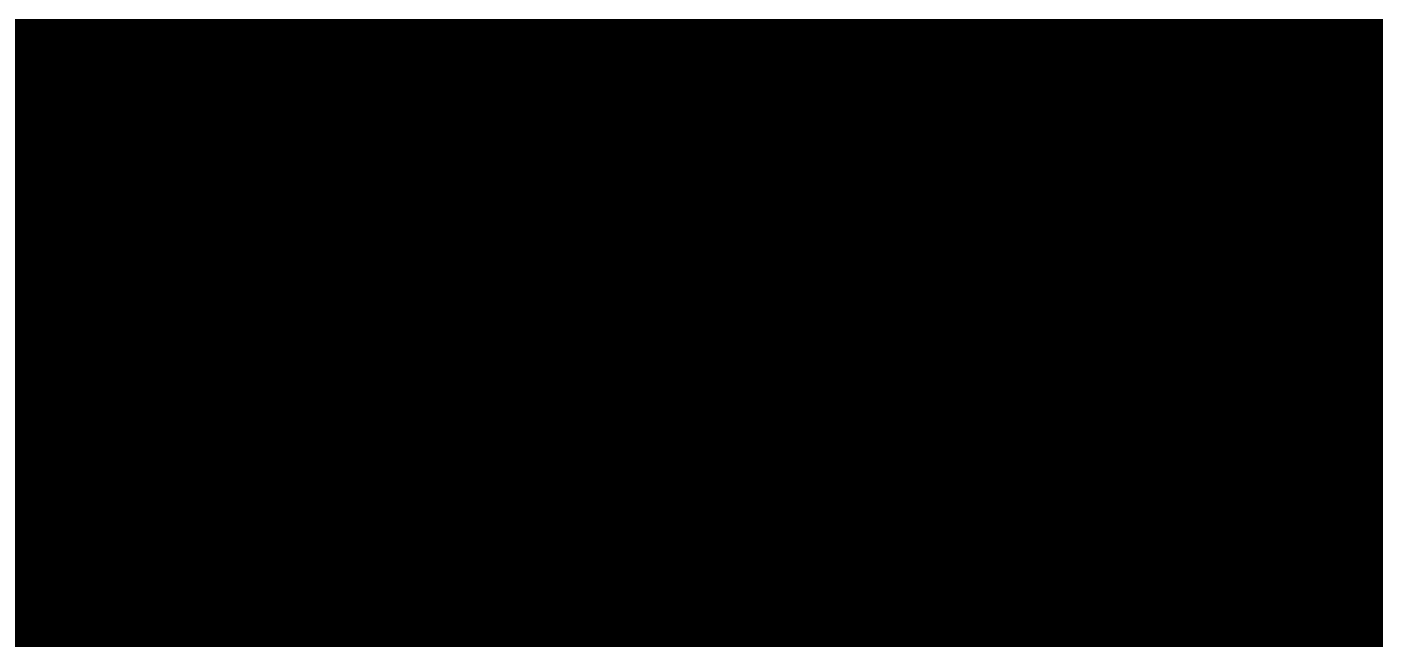

Do total de FNV de adolescentes de 10 a 19 anos, em 1998, no Estado de São Paulo, 76,5\% eram filhos primogênitos e, 23,5\% eram filhos de mulheres que estavam tendo FNV pela segunda ou mais vezes. Em 2002, o percentual de primogênitos diminuiu para $73 \%$, mas aumentou para $27 \%$ o percentual de adolescentes que deram à luz ao segundo, terceiro (ou mais) filho nascido vivo. 
Portanto, o que reduziu no período analisado por TAKIUT ${ }^{117}$ e $^{118}$, foi a proporção de adolescentes nulíparas que tinham filho nascido vivo pela primeira vez. Entretanto, as primíparas, aquelas que já tinham um FNV, voltaram a ter um segundo ou mais filhos em curtos intervalos e antes dos vinte anos.

A análise desse fenômeno permite advogar e levantar a hipótese de que as maternidades sucessivas em adolescentes estão ocorrendo de forma semelhante no restante do país. Entretanto, não se encontrou dados específicos publicados a esse respeito para o âmbito nacional. Os dados mais próximos e que permitem associações às maternidades sucessivas na adolescência, são os que foram divulgados pelos relatórios SAÚDE BRASIL $2004{ }^{23}$; SAÚDE BRASIL $2005^{24} \mathrm{e}$ SAÚDE BRASIL $2006^{26}$ e se referem à dinâmica reprodutiva da população com menos de 15 anos.

Os dados apontam para a manutenção em percentuais estáveis, média de $0,9 \%$ nos últimos anos, das gravidezes na faixa etária 'menores de 15 anos' Esse aspecto da dinâmica reprodutiva brasileira parece explicar as ocorrências de várias gravidezes na adolescência, porque o fato de 'ter tido filho antes dos 15 anos' aumenta consideravelmente as chances de ser mãe pela segunda vez na adolescência ${ }^{20,34}$. Entretanto, há que destacar que muitas adolescentes podem, mesmo após os 15 anos, ter consecutivamente dois ou mais filhos e, ainda assim, serem adolescentes.

De maneira geral, não se observa que as 'maternidades sucessivas na adolescência' se firmaram como um capítulo de estudo da saúde pública, diferentemente dos pesquisadores norte-americanos, que há anos estudam o fenômeno, lá denominado de rapid repeat pregnancy ${ }^{103}$.

Poucos trabalhos exploram a temática de modo específico e consistente. Na maioria das vezes, o tema se encontra disperso e citado superficialmente em pesquisas sobre a 'gravidez na adolescência', geralmente, como mais uma das conseqüências indesejáveis do 'início sem planejamento' da vida sexual/reprodutiva.

\footnotetext{
III Um considerável avanço referente aos estudos da saúde reprodutiva do adolescente foi a adoção pelo censo demográfico de 2000, "da faixa etária de 10 a 14 anos, como idade reprodutiva, o que tem resultado em ganhos de informações importantes para a formulação de políticas públicas" ${ }^{27}$.
} 
A conceituação 'maternidades sucessivas na adolescência' é uma tentativa de superação da noção de 'gravidezes na adolescência', pois essa se mostra insuficiente para objetivar toda a envergadura do que nesse estudo se está considerando 'maternidade na adolescência' e que inclui todo o processo 'gravidez, gestação e nascimento de filho vivo'.

Aliás, no senso comum e em alguns estudos, a expressão 'gravidez' é usada como sinônimo de 'número de filhos', quando, na realidade, pode não ser, pois, pode haver abortos provocados ou não e natimortos. HEILBORN ${ }^{57}$ considera que esse "deslizamento semântico" desconsidera "a magnitude da gravidez na adolescência".

Portanto, 'maternidades sucessivas na adolescência' se reporta à ocorrência de duas ou mais gravidezes, seguidas de gestação e pelo nascimento de filho vivo antes do 20 anos, não importando o quão cedo ocorreu o primeiro evento e o intervalo entre um e outro e se houve alguma gravidez/gestação não levada a termo. Decorrência imediata dessa generalização foi a adoção do conceito 'número de filhos nascidos vivos' (FNV) como o indicador que melhor se aproximou e objetivou o fenômeno em estudo. Aliás, 'número de filhos nascido vivos' é largamente usado na literatura científica e nos registros de dados oficiais.

$\mathrm{Na}$ literatura, os conceitos encontrados para se reportarem ao que denominamos 'maternidades sucessivas na adolescência' foram os seguintes: multigravidez, multíparas, multigestas na adolescência ${ }^{92,107}$, repetição da gravidez 07, 36, 61, 66, 89, 90, 115, gravidez reincidente, gravidez subseqüente, gestações sucessivas ${ }^{61}$, nascimentos subseqüentes em adolescentes ${ }^{60}$, recidivismo ${ }^{103}$ e repetição rápida de gravidez ${ }^{59,103,116}$.

Esses conceitos por si próprios anunciam diversas concepções acerca de como são explicadas as situações de ocorrência de maternidades sucessivas na adolescência. Tendo em vista que PERSONA e col. ${ }^{89}$ elencaram uma série delas e às quais, aqui, se acrescentou outras, se compôs o seguinte panorama: 
a - situações relacionadas aos marcadores biológicos: idade ${ }^{18}$ e 89 , menarca precoce, primeira relação sexual logo após a menarca, abortos

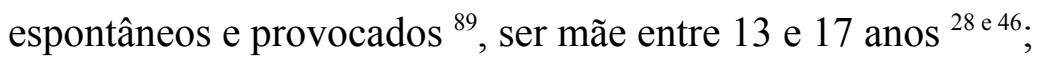

b - situações vinculadas aos aspectos psicossociais: religiosidade ${ }^{18}$, repetência e abandono escolar, história familiar de gravidez na adolescência, ausência do pai por morte ou abandono, reação positiva da família à gravidez anterior, parto anterior bem conceituado pela adolescente ${ }^{89}$, não retorno à escola após o primeiro parto ${ }^{56} \mathrm{e}^{112}$ e histórico de violência física ou sexual ${ }^{25 \mathrm{e} 28}$;

c - situações vinculadas aos aspectos afetivos: namoro ${ }^{18}$, envolvimento com parceiros mais velhos, casamento, união consensual com parceiro, parceria sexual fixa, intenção ou desejo pela primeira gravidez, namorado que deseja um filho ${ }^{81}$;

d - situações vinculadas aos aspectos econômicos: ausência de ocupação remunerada e baixa renda familiar ${ }^{89}$;

e - situações vinculadas ao não uso, uso inadequado ou dificuldades de acesso às tecnologias de saúde: ausência de consulta médica pós-parto ao parto anterior, baixa adesão ao uso de preservativos ${ }^{89}$, não uso de anticoncepcional pósparto ${ }^{61 \mathrm{e} 114}$, uso inadequado de anticonceptivos ${ }^{77}$.

A análise desse panorama permitiu supor que são tantas as situações que tornam as adolescentes vulneráveis à segunda ou mais maternidades que dificilmente se conseguiria estabelecer uma linearidade causal. Ao contrário, o que parece existir é uma complexidade causal, que deve, em algum momento, influenciar, possibilitar e favorecer a gravidez.

Talvez, por isso, as concepções mais radicais sobre 'prevenção à gravidez na adolescência' tomem a abstinência sexual e o uso de anticoncepcionais por princípio. Contudo, parece que tais soluções funcionam muito mais como 'cala-bocas' à metáfora que a maternidade na adolescência insiste em simbolizar do que uma saída razoável. 
A respeito dos percentuais de ocorrências de maternidades sucessivas em adolescentes, em diversas regiões do país, temos o seguinte ${ }^{\mathrm{IV}}$ :

- o estudo realizado por SIMÕES e col. ${ }^{111}$ (2003) em São Luís - MA, em que se constatou que 37,7\% das mulheres de 18 a 19 anos e $13,7 \%$ das abaixo de 18 anos já tinham de dois a quatro filhos.

- a pesquisa realizada por CHABAN Jr. e col. ${ }^{34}$ (2003), em Porto Acre-AC, com adolescentes grávidas de 15 a 19 anos, onde foram encontradas $38,5 \%$ delas numa segunda gestação e $7,7 \%$ numa terceira, totalizando $46,2 \%$ de repetição da gravidez.

- o levantamento ${ }^{68}$ realizado em Recife-PE, sobre vias de parto em adolescentes de 13 a 19 anos, em que se observou que 20,9\% delas tinham realizado um segundo parto, $4,9 \%$ o terceiro e $0,4 \%$ o quarto parto, totalizando $26,2 \%$ com mais de um parto.

- o estudo realizado por BORGES ${ }^{18}$ (2004) sobre aspectos afetivoamorosos e perfil reprodutivo de mulheres adolescentes na zona leste de São Paulo, que encontrou no grupo estudado, $17,1 \%$ de adolescentes que já eram mães de pelo menos um filho.

- a investigação realizada por TAKIUTI ${ }^{117}$ (2004), que encontrou 16\% de adolescentes numa segunda gravidez na Casa do Adolescente de Pinheiros/São Paulo-SP e 15\% no Centro de Atendimento ao Adolescente de Jacareí-SP.

- o estudo realizado por RUGOLO ${ }^{107}$ (2004) sobre os sentimentos e percepções de puérperas num hospital universitário de Botucatu-SP e que identificou $12 \%$ de adolescentes multíparas.

- a pesquisa realizada por SIQUEIRA e col. ${ }^{112}$ (2002) com adolescentes grávidas de até 19 anos, em quatro programas de pré-natal de Florianópolis-SC, localidade onde os autores encontraram 9,5\% de adolescentes grávidas pela segunda ou mais vezes.

\footnotetext{
IV $\mathrm{Na}$ apresentação destes dados usou-se a terminologia adotada pelos respectivos autores para se referirem ao fenômeno aqui nomeado de 'maternidades sucessivas'.
} 
- a investigação realizada por CHEMELLO ${ }^{17}$ (1999) em que traçou o perfil da gravidez em adolescentes no município de São Marcos-RS e encontrou $5,2 \%$ de gravidezes subseqüentes.

Esses trabalhos, consideradas as especificidades metodológicas de cada um, sinalizam que as maternidades sucessivas na adolescência estão associadas às características sociais, históricas, econômicas e culturais de cada região, às quais estão afeitas essas adolescentes, pois, nas regiões sul e sudeste do país, as mais desenvolvidas, os percentuais variam de 5,2\% a $16 \%$, enquanto que nas regiões do norte e nordeste, menos desenvolvidas, encontrou-se até 46,2\% de gravidezes subseqüentes.

A respeito da idade da primeira e outras maternidades e sobre o período transcorrido entre elas, PERSONA e col. ${ }^{46}$ observaram que $44 \%$ das adolescentes atendidas no CAISM/UNICAMP, em Campinas-SP, tinham 17 anos e para $72,2 \%$ delas, a primeira gravidez havia ocorrido em torno dos 15 anos.

Esse dado é corroborado por vários autores ${ }^{103,114}$, que destacam a correlação entre a repetição da gravidez, maior número de filhos ao fim de um período e a idade da primeira gravidez, que, por sua vez, está relacionada com o início da atividade sexual antes dos 14 anos. Quanto antes uma primeira gravidez, maior a possibilidade de uma segunda.

A respeito da relação entre maternidades sucessivas e uso de contraceptivos, STEVENS-SIMON e col. ${ }^{114}$ (2001), numa pesquisa sobre uso de anticoncepcional realizada nos EUA, referem que entre aquelas adolescentes que estavam em "repetição de gravidez", 14\% haviam ficado grávidas em até um ano após o parto anterior e $35 \%$ em até dois anos. Da mesma forma, OLIVEIRA ${ }^{81}$ (2003), ao relatar dados de pesquisa realizada no Brasil, aponta que até $40 \%$ das adolescentes ficaram grávidas novamente logo no primeiro ano após o primeiro parto e esse percentual aumentou para até $50 \%$, quando se considerou os dois anos seguintes ao primeiro parto.

TAKIUT ${ }^{117}$ aponta que o uso de anticoncepcionais pelas adolescentes que reincidiram na gravidez estava em torno de apenas $35 \%$ em programas de 
atenção ao adolescente na cidade de São Paulo. RIGSBY ${ }^{103}$, por sua vez, diz que, embora muitas gravidezes de rápida repetição sejam intencionais, muitas não são e poderiam ser prevenidas com anticoncepção eficaz e com uso adequado. Refere ainda, que o número de gravidezes sucessivas é muito maior entre aquelas que não usam anticoncepcional algum.

A propósito da escolaridade de adolescentes com maternidades sucessivas, CHABAN ${ }^{34}$ descreve que num grupo estudado, 38,4\% possuíam o primeiro grau incompleto e $23,1 \%$ eram analfabetas. TAKIUTI ${ }^{117}$, por sua vez, refere ter encontrado entre as adolescentes "reincidentes", $65 \%$ que não completaram o primeiro grau. De igual modo, CHEMELLO ${ }^{35}$ constatou que $84,3 \%$ não haviam concluído o primeiro grau.

PERSONA e col. ${ }^{89}$ verificaram que $50 \%$ das adolescentes não concluíram o primeiro grau e que apenas $16,67 \%$ não interromperam os estudos por causa da gravidez. STEVENS-SIMON e col. ${ }^{115}$ referem que o retorno da adolescente aos estudos após o parto contribui para a não "reincidência" da gravidez. Entretanto, destaca que essa condição raramente ocorre, tendo em vista que, muitas vezes, a adolescente já estava sem vínculo com a escola quando ocorreu a primeira gravidez.

Ao se considerar o estado civil de adolescentes com sucessivas maternidades, CHEMELLO ${ }^{35}$ apurou que $85,5 \%$ estavam numa parceria conjugal estável com o pai do primeiro filho. Da mesma forma, PERSONA e col. ${ }^{89}$ apontam dados, que permitem concluir que $73,2 \%$ estavam amasiadas ou casadas ao repetirem a gravidez, percentual praticamente inverso ao momento da primeira gravidez, em que $66,6 \%$ referiam estar "solteiras".

Analisando esse fenômeno de outro prisma, temos vários pesquisadores 37,39 e 40 que relacionam a gravidez na adolescência a conflitos psicológicos, como insegurança, baixa estima e ausência de projeto de vida que não seja apenas a maternidade. Parece que é possível estender essa compreensão para a análise das maternidades sucessivas na adolescência. 
Nessa acepção, a gravidez e a maternidade de adolescentes são consideradas como eventos que podem ser determinados por demandas internas da adolescente, decorrentes de desejos conscientes em que se imaginam muito gratificadas ao serem mães e/ou por desejos inconscientes, em que buscam fantasiosamente com a gravidez e com um filho, suprir carências afetivas e sensações de desamparo ${ }^{39}$. Nesse sentido, há que acrescentar que muitas adolescentes grávidas são filhas de mães que também ficaram grávidas quando adolescentes e que não chegaram a constituir um grupo familiar.

Dessa forma, elas podem apenas repetir uma história familiar e transferem para o filho suas próprias necessidades, oferecendo-lhes tudo aquilo que elas imaginam não terem tido, como carinho, proteção e família. Assim, uma ou várias maternidades na adolescência podem ser respostas a uma necessidade psíquica de recomposição de uma família, nunca tida, perdida, fantasiada ou vivenciada como insatisfatória.

Persona et al.$^{89}$ ao estudarem a "ausência do pai da adolescente grávida", solicitaram às adolescentes uma avaliação de sua relação com os pais. Elas atribuíram valor dez à convivência com a mãe e valor zero à relação com o pai. As autoras apontam, ainda, que entre aquelas que tinham o pai ausente, 87,5\% estavam casadas ou amasiadas. Rigsby ${ }^{103}$, por sua vez, destaca a existência de percentuais menores de "gravidezes de rápida repetição" em adolescentes que convivem com pai e mãe, pois a estabilidade familiar seria um fator protetor.

Esses dados sugerem um campo de pesquisa importante, tendo em vista o seu intrincamento psicossocial, a importância da paternidade para a constituição da subjetividade e a crescente formação de arranjos de grupos familiares em que está ausente a figura paterna. Aliás, muito pouco se observa na literatura científica o trato da possível relação existente entre maternidade de adolescentes e a ausência/presença do pai da adolescente. Curiosamente, também a paternidade adolescente foi por muito tempo renegada pelos estudos e apenas recentemente está sendo estudada.

Finalmente, convém destacar que as situações de vulnerabilidade às maternidades sucessivas podem ser minoradas com intervenções adequadas. Monteiro e col. ${ }^{74}$ ao analisarem resultados de um programa de acompanhamento 
às gestantes e mães adolescentes, realizado no Rio de Janeiro - RJ, concluíram que com a intervenção, houve um alto percentual de partos normais, 89,3\%, e a elevação do percentual de adolescentes adeptas ao uso de anticoncepcionais. Antes da primeira gestação, apenas 17\% usavam e após o parto, 71,9\% adotaram o contraceptivo. Com isso, reduziu para $5,2 \%$ o percentual de novas gravidezes no ano seguinte ao parto. 


\section{4 - A MATERNIDADE E A FEMINILIDADE}

Muito pouco se têm investigado, numa interface com a saúde pública, as questões psíquicas do desenvolvimento humano que se relacionam com a sexualidade e suas repercussões ao longo da adolescência. A Psicanálise é, seguramente, uma das teorias que conseguiu contemplar a sexualidade de forma ímpar e propor um conjunto de subsídios que colaboram para o avanço do conhecimento na área.

FREUD ${ }^{47}$ (1905), diz que a sexualidade humana não se restringe apenas aos aspectos externalizados na vida sexual dos adultos. Ao contrário, desde a tenra infância já existe sexualidade, sendo que, nesse momento, sua expressão e prazeres são polimorfos e distribuídos em diversas zonas erógenas. $\mathrm{O}$ autor ${ }^{47}$ acrescenta que a sexualidade só rompe sua organização infantil na adolescência, quando as fontes de prazer se unificam nos genitais, ocasião, em que as pulsões sexuais parciais se articulam para propiciar a reprodução e a busca do prazer coincide com os meios que possibilitam a reprodução e vice-versa.

Esse percurso é conhecido como desenvolvimento psicossexual e é fundante do sujeito psíquico, pois permite a escolha de um objeto amoroso fora do núcleo afetivo inicial - o grupo familiar -, acesso à genitalidade e estruturação subjetiva. Ou seja, a diversidade que constitui a existência humana é decorrência dos arranjos da sexualidade infantil e da forma como essa se articula num intricado campo de identificações com os pais, o primeiro meio social.

Com a finalidade de compreendermos os fenômenos nos termos ora elaborados, é preciso ter claro que a problemática em discussão alude à dinâmica inconsciente da constituição psíquica e, possivelmente, à forma como os contextos sociais, históricos e culturais contribuem ou atrapalham as adolescentes nesses processos de individuação e principalmente, de consolidação da feminilidade, que pode se dar por meio da maternidade.

Com isso, frente ao imperativo de considerar que o fenômeno das gravidezes e maternidades na adolescência está condicionado pelos determinantes 
das condições de vida, tem-se que acrescentar que o desenvolvimento psicossexual, e no caso das adolescentes, a busca pela feminilidade, pode ter também, considerável influência.

É possível, portanto, considerar que a gravidez na adolescência, bem como sua repetição, pode associar-se às tentativas de elaborar sua 'separação' da mãe e de buscar outro objeto amoroso. Assim, a gravidez e maternidade funcionam como atalhos que buscam evitar frustrações, permitindo a conquista do desejado no ato, na ação, no comportamento manifesto, negando a 'angústia' de sua separação do mundo infantil e de tudo a ele relacionado, vivência que deveria ocorrer no simbólico.

Parece, deste modo, que é necessário incluir a dimensão subjetiva como pertencente às condições de vida, pois ao mesmo tempo em que pode ser influenciada por essas, também pode modificá-las. Ou seja, as condições de vida são mediadas por sujeitos psíquicos, que não são passivamente afetados. Há movimentos reativos, pontos de fuga e elaborações que buscam integrar diferentes necessidades internas e pressões ambientais. Assim, a subjetividade é o meio em que se processam as diferentes demandas, quer sejam da realidade externa ou do mundo interno.

Partindo desse referencial, é preciso resgatar o conceito de gravidez indesejada. Curiosamente, parece ser um conceito que tenta afirmar-se pela negação do desejo, por insistir em dizer do 'não-desejo', do ‘não-querer'. Mas há um contra-senso nisso, uma denúncia, uma metáfora. Não é possível negar o desejo, pode-se tentar, mas uma vez desejado, desejo é. Como dizer, então, que a gravidez é 'indesejada'?

Parece-nos que esse conceito, assim como um ato falho, nos dá uma dica. Será mesmo que existe gravidez indesejada? Será mesmo que não houve desejo? Sabemos que mecanismos inconscientes norteiam os sujeitos a tal ponto que, mesmo racionalizando ou negando seus desejos, entrega-se a comportamentos que, provavelmente, concretizarão, de uma forma ou outra, o desejo não reconhecido. 
Estamos, portanto, conceituando que a gravidez e a maternidade na adolescência - e, provavelmente, em todas as etapas da vida - expressam um desejo, e não, como querem alguns, o indesejo. Muito mais que um trocadilho, esse raciocínio traz à baila, o debate entre razão e desrazão, entre controle e descontrole, entre 'não posso, mas quero', entre 'correr e não correr riscos'. Obviamente que no senso comum quando se refere à gravidez indesejada, está se falando no sentido de 'não-planejada', mas não é possível deixar de assinalar seus outros sentidos.

ABRAMOWAY ${ }^{01}$, em raciocínio análogo à problematização feita acima, diz que, ao

sublinhar o caráter de problema e associar gravidez na adolescência com gravidez "indesejada" ou "não planejada", sutilmente se marginalizam análises sobre o simbólico, os significados para os jovens de suas experiências (..) Medos, inseguranças, baixa autoestima, assimetrias de gênero nas negociações sobre direitos sexuais e reprodutivos podem derivar em uma gravidez, quer para mulheres jovens quer para adultas, inclusive como forma compensatória. Aliás, é interessante notar que se acentua o caráter de não planejada, não desejada, para as gravidezes ocorridas entre jovens, sem se fazer referência que tal tipo de gravidez possa ocorrer também para mulheres adultas ${ }^{01}$ (p. 134).

Provavelmente, isso explica porque, apesar dos incessantes esforços dos programas governamentais e de outras esferas para informar adolescentes sobre os meios de proteção à gravidez e ao HIV, ainda assim as gravidezes não planejadas e as infecções sexuais continuem ocorrendo. Entretanto, não se nega que nas regiões mais carentes, onde a falta de informação e meios contraceptivos ainda é aviltante, muitas gravidezes acorram por isso. Contudo, como explicar, aquelas adolescentes que mesmo tendo acesso facilitado, ainda assim usam incorretamente, esquecem de usar e ficam grávidas?

Ou seja, a articulação da informação passa pelas condições sociais, econômicas e culturais, mas passa também pelo psíquico. Garantir informações e condições de acesso a anticonceptivos não tem sido suficiente. O desejo é sempre deseducado e não atende aos apelos da razão e dos planejamentos externos. 


\section{2 - OBJETIVOS}

Este estudo teve por objetivo geral caracterizar e analisar os contextos reprodutivos, sócio-econômicos e individuais de adolescentes com maternidades sucessivas.

O objetivo geral departiu-se em três objetivos específicos:

1 - caracterização e análise da dinâmica reprodutiva da população adolescente do município de Rondonópolis-MT;

2 - caracterização e análise das condições sócio-econômicas das adolescentes com maternidades sucessivas e,

3 - levantamento e análise das histórias de vida de adolescentes com maternidades sucessivas naquilo que se referiam à sexualidade e às suas maternidades. 
CAPÍTULO II

OS CAMINHOS 


\section{3 - LOCAL DA PESQUISA}

"Coisa mais bela neste mundo não existe / Do que ouvir um galo triste, no sertão se faz luar / Parece até que a alma da lua é que descanta / Escondida na garganta do galo a soluçar Não há, oh gente, oh não, luar como esse do sertão".

O Luar do Sertão - Vicente Celestino

A pesquisa foi realizada com adolescentes grávidas residentes no município de Rondonópolis, Estado de Mato Grosso, região Centro-Oeste do Brasil. A estimativa atual, realizada pelo $\mathrm{IBGE}^{58}$, para a população do município de Rondonópolis-MT indica que já deve ter ultrapassado 170.000 habitantes.

Contudo, no Censo 2000 58, o município contava com 150.227 habitantes, sendo 75.287 do sexo feminino e 74.940 do sexo masculino. No mesmo ano, contou-se na faixa etária de 10 a 19 anos, 31.407 pessoas, ou seja, $21 \%$ da população. A partir da estimativa do IBGE ${ }^{58}$, calculou-se que o crescimento da população rondonopolitana, no período de 2000 a 2006, foi de $11 \%$.

Conforme relata a historiadora TESORO ${ }^{119}$ (2002), desde o final do século XIX o homem branco está presente na Região de Rondonópolis. Antes, conta-se que a localidade era habitada apenas por índios Bororos. Nos idos de 1875, deslocou-se para a região um destacamento militar, pois já havia grandes comitivas de aventureiros que vagavam pela região em busca de ouro e pedras preciosas.

Nos anos 1907/1909, sob o comando do então primeiro tenente Cândido Rondon, houve a expedição da Construtora de Linhas Telegráficas Gomes Carneiro, demarcando o trajeto da linha telegráfica para interligar o Estado do Mato Grosso e Amazonas ao resto do país. Em conseqüência, em 1922, é inaugurado o posto telegráfico às margens do Rio Poguba, hoje chamado de Rio Vermelho ${ }^{119}$. 
A constituição do 'Povoado do Rio Vermelho', inicia-se, a partir de 1902, com a chegada de famílias provenientes de Goiás, Cuiabá e outras regiões do país. Em 1915 contava-se cerca de setenta famílias na localidade e vivendo com certa organização social. Segundo TESORO ${ }^{119}$ nesse mesmo ano,

Joaquim da Costa Marques, Presidente de Estado do Mato Grosso, promulga o Decreto Lei $\mathrm{n}^{\circ} .395$ que estabelecia uma reserva de 2.000 hectares para o patrimônio da povoação do Rio Vermelho. Esse decreto marca oficialmente a existência do povoado (a futura cidade de Rondonópolis), cuja data de fundação (10 de agosto de 1915) foi regulamentada pela Lei Municipal 2.777 de 22 de outubro de 1997. Em 1918, o deputado, agrimensor e tenente Otávio Pitaluga conclui o projeto de medição, alinhamento e estética da localidade; projeto que em 1948 foi aproveitado pelo engenheiro Domingos de Lima para edificar o traçado do atual quadrilátero central. Pitaluga foi também o responsável pela alteração de nome do povoado para Rondonópolis, em 1918, uma homenagem a Rondon que passa então a ser considerado o patrono do lugar. Em 1920, Rondonópolis transformase em distrito de Santo Antônio do Leverger e comarca de Cuiabá ${ }^{119}$ (p. 13).

Contudo, na década de 20, o vilarejo entra em decadência, haja vista as constantes enchentes, epidemias e a descoberta dos garimpos de diamantes, em 1924, na localidade vizinha chamada de Poxoréo. O município é despovoado, com a debandada de sua população para Poxoréo, que em 1938, por meio da Lei Estadual $n^{\circ}$. 218 de 1938 passa de distrito a município. De 1930 a meados de 1947, o município de Rondonópolis permaneceu abandonado ${ }^{119}$.

Diz TESORO ${ }^{119}$, que com a implantação da política do sistema de colônias, implantado pelo governo do Estado em 1947, o município volta a crescer e definitivamente se insere no modelo capitalista de produção como fronteira agrícola do Mato Grosso. Em 10 de dezembro de 1953, houve a emancipação política do até então distrito. TESORO ${ }^{119}$ diz que

"nas décadas de 50 e 60, o crescimento econômico de Rondonópolis vem através do campo, enquanto produtor de alimentos e extensão do capital paulista. Nesse período destaca-se a força da mão-de-obra de migrantes mato-grossenses, nordestinos, paulistas, mineiros, japoneses e libaneses. Na década de 70 acelera-se no município o processo de expansão capitalista, e Rondonópolis desenvolve o mais rápido processo de modernização do campo que se teve notícia no Centro Oeste, incrementando as atividades da soja, da pecuária e do comércio. 
Aqui a migração sulista é o destaque. Em 1980, Rondonópolis passa a ser pólo econômico da região e é classificado como segundo município do estado em importância econômica, demográfica e urbana. Já, na década de 90, Rondonópolis projeta-se como "A Capital Nacional do Agronegócio", ao mesmo tempo em que cresce o setor agroindustrial 119 (p.15)

Tida nos últimos anos como terra de oportunidades, Rondonópolis-MT está localizada há $920 \mathrm{~km}$ ao oeste de Brasília-DF e a $212 \mathrm{~km}$ ao leste de Cuiabá, capital mato-grossense, num importante entroncamento de rodovias estaduais (MT 130 e MT 270) e federais que ligam o Sul e Norte do país (BR 163) e o Centro-Oeste ao leste (BR 364). Caracteriza-se como um ponto de passagem obrigatório de bens e mercadorias.

Com essas características, tornou-se cidade pólo de uma vasta região que congrega a economia de cerca de 20 municípios, que têm em Rondonópolis uma referência para busca de bens, mercadorias e serviços. A localização privilegiada a coloca como portal da Amazônia e entrada para o pantanal matogrossense.

Embora tenha uma economia pungente, o modelo econômico que sustenta o agronegócio e a economia regional produz intensa concentração de renda, o que obriga expressivo contingente populacional a sobreviver com baixa remuneração, conforme Tabela 1.

Tabela 1- Distribuição de renda por classe social em Rondonópolis-MT, 2005.

\begin{tabular}{cccc}
\hline Classe & $\begin{array}{c}\text { Renda Familiar } \\
\text { Média }-(\mathbf{R} \mathbf{})\end{array}$ & $\begin{array}{c}\text { Média Brasil } \\
\mathbf{\%}\end{array}$ & $\begin{array}{c}\text { Média Rondonópolis } \\
\mathbf{\%}\end{array}$ \\
\hline A1 & $7.793,00$ & 1 & 0,3 \\
\hline A2 & $4.648,00$ & 5 & 2,1 \\
\hline B1 & $2.804,00$ & 9 & 5,4 \\
\hline B2 & $1.669,00$ & 14 & 10,2 \\
\hline C & 927,00 & 36 & 36,7 \\
\hline D & 424,00 & 31 & 43,3 \\
\hline E & 207,00 & 4 & 2,0 \\
\hline Total & - & $\mathbf{1 0 0}$ & $\mathbf{1 0 0}$ \\
\hline & Fonte: Prefeitura Municipal de Rondonópolis-MT/ACIR, $2006^{95}$.
\end{tabular}


Também os índices de desemprego mostram-se elevados, atingindo, $11,7 \%$ da população geral e, $21,6 \%$ da população economicamente ativa. Entre os trabalhadores que se declaram 'chefes de família', 38\% são autônomos, 32,5\% trabalham na iniciativa privada, 12,9\% são aposentados, 8,4\% funcionários públicos e 3,3\% profissionais liberais (Prefeitura Municipal de RondonópolisMT/ACIR, 2006) ${ }^{95}$.

Quanto à escolaridade dos 'chefes de família', 15,9\% não terminaram o primário, 29,4\% não completaram o ginasial e 21,5\% não completaram o colegial. No que se refere ao ensino superior, 9,9\% concluíram-no ${ }^{95}$.

É impossível compreender a forma como se desenvolveu o perfil sócio-cultural-demográfico do município sem remeter-se aos constantes fluxos migratórios ocorridos desde a sua fundação. Inicialmente, com o intuito de integrar os sertões ao sudeste e sul do país, depois com a corrida pelas pedras preciosas e, posteriormente, com a agropecuária.

O município de Rondonópolis sempre esteve na rota desses investimentos, cada qual deixando suas contribuições, mas também, as conseqüências indesejáveis, como o crescimento urbano desordenado, a ocupação e uso irregular dos recursos naturais, o crescimento populacional muito além do investimento em políticas públicas, entre outras.

Um dos reflexos mais visíveis das migrações está na composição sócio-demográfica da população. Entre os chefes de família', 48\% vieram de outros estados, mas mesmo entre aqueles que nasceram na região, os pais vieram de outras regiões do país.

Dois grandes grupos de migrantes podem ser caracterizados: aqueles que vieram do sul e sudeste do Brasil (com origem européia, asiática e árabe) e os que vieram do nordeste brasileiro. Grosso modo, os primeiros vieram para ser patrões, os demais, para serem empregados. Há que se dizer também que os indígenas foram os primeiros habitantes, sendo que os Bororos sempre ocuparam a região. De certa maneira, ainda é possível reconhecer o Brasil colonial nesses rincões. 
Nesse sentido, há grande diversidade de matrizes étnico-culturais na formação da população local e se relacionam ao modo como se organizam não apenas as questões sócio-econômicas, mas também os costumes, a moral e as formas de lidar com diferentes dimensões da existência, como a sexualidade, a vida afetiva, o trabalho, entre outras. 


\section{4 - SELEÇÃO DAS PARTICIPANTES}

A população de referência para seleção das participantes da pesquisa foi o universo composto por todas as mulheres residentes no município de Rondonópolis-MT, que no período compreendido entre os meses de janeiro e maio de 2007:

a) tinham idade entre 15 e 19 anos;

b) eram mães de um ou mais filhos nascidos vivos;

c) estavam grávidas novamente, $\mathrm{e}$

d) estavam inscritas no SISPRENATAL ${ }^{113}$ (Sistema de Acompanhamento do Programa de Humanização no Pré-Natal e Nascimento) do município de Rondonópolis-MT.

Inicialmente, planejávamos compor o universo de participantes a partir dos dados consolidados junto ao SINASC ${ }^{25}$ e, conseqüentemente, compô-lo com todas as adolescentes que já haviam dado à luz ao segundo ou mais filhos nascidos vivos, independentemente de ter feito o parto no SUS ou não. No SINASC ${ }^{25}$ todos os dados dos recém nascidos são relacionados, independente da classe social e do local de realização do parto.

Entretanto, a Secretaria Municipal de Saúde de Rondonópolis-MT, alegando que deveria manter o 'zelo ético' das informações, não facultou o acesso a algumas informações registradas no SINASC ${ }^{25}$, justamente aquelas que permitiriam a identificação dos endereços das parturientes. Por isso, optamos por realizar o estudo a partir do cadastro do SISPRENATAL ${ }^{113}$, recurso que nos foi disponibilizado. Entretanto, nesse banco de dados são cadastradas apenas as mulheres gestantes que estão fazendo o pré-natal pelo SUS.

Apesar de no momento ter causado muitas dificuldades para a coleta de informações, a experiência mostrou-se muito produtiva. Inicialmente, identificamos nas condições estipuladas 79 (setenta e nove) mulheres. Para identificá-las, foram obtidas as informações do SISPRENATAL ${ }^{113}$, que 
posteriormente, foram verificadas e confirmadas ou não in loco, na unidade de saúde em que cada gestante realizava ou deveria realizar o pré-natal. Para isso, foram visitadas 34 unidades básicas de saúde, das quais, 28 eram Núcleos de Saúde da Família (NSF), 04 eram Centros de Saúde e 02 eram Postos de Saúde.

Nas unidades de saúde, entregávamos e explicávamos à coordenação do local, o projeto de pesquisa. Em seguida, combinávamos a realização de uma reunião com os agentes comunitários de saúde. Nessa reunião apresentávamos o projeto de pesquisa e os critérios para seleção das participantes.

Com isso, identificávamos os agentes comunitários de saúde que eram os responsáveis pelas gestantes até então selecionadas. A troca de informações com eles permitiu ajustar as informações obtidas no SISPRENATAL ${ }^{113} \mathrm{e}$ atualizar o grupo de participantes, pois muitas mulheres já haviam dado à luz e outras estavam grávidas, preenchendo os critérios de seleção.

A parceria com os agentes comunitários de saúde pautou-se também pelo acompanhamento que nos fizeram até à residência das gestantes e apresentação a elas. Esse procedimento foi adotado logo após as primeiras tentativas de localizá-las sem a presença dos agentes comunitários de saúde.

A primeira dificuldade referiu-se à 'sensação de estranhamento' com que a população local nos observava enquanto procurávamos as participantes. Chegou ao ponto de nos confundirem com 'policiais à paisana', 'conselheiros tutelares', 'ladrão de crianças', 'oficial de justiça', 'médico', entre outras designações. Aliás, essas falas inspiram várias interpretações sobre as representações que determinada comunidade tem acerca dos 'estranhos' que adentram a ela.

A companhia dos agentes de saúde permitiu, de certa forma, circular no bairro como um 'estranho autorizado' e que tinha um passaporte para ali estar. Facilitou também a localização das residências das gestantes, pois os endereços apontados no SISPRENATAL ${ }^{113}$ nem sempre eram os mesmos, pois muitas já haviam 'mudado de casa' e estavam morando com parentes, conhecidos, parceiros ou mesmo em casas recém alugadas. 
Por coincidência, encontramos em outros bairros distantes, participantes que havíamos dado por 'não localizadas' no bairro que constava no endereço do SISPRENATAL ${ }^{113}$ e consideradas como 'desaparecidas' pelas agentes comunitários de saúde.

Há que registrar, também, que a nomeação de ruas e numeração das casas nem sempre eram correspondentes ou corretas. De qualquer forma, a utilização de um mapa da cidade foi um instrumento indispensável para traçar rotas de visitas e localização de endereços, tanto das unidades de saúde quanto das participantes.

O acompanhamento feito pelos agentes comunitários de saúde foi muito valioso, sobretudo, por nos apresentarem às gestantes e a seus familiares. Denotando a importância da presença dos agentes, muitas adolescentes aceitaram nos receber somente após, discretamente com uma 'olhadela', consultá-los. A partir desse momento, explicávamos os objetivos da pesquisa e confirmávamos as informações necessárias para incluí-las ou não como participantes da pesquisa.

Quando confirmadas as informações, fazíamos o convite para que participassem da pesquisa e apresentávamos o Termo de Consentimento Livre e Esclarecido, deixando as cópias para que lessem e decidissem sobre a participação na pesquisa. Após alguns dias, voltávamos para saber se aceitavam participar e, então, iniciávamos os trabalhos, que aconteceram em seus domicílios. Após todos esses procedimentos, apurou-se a efetiva participação de 49 (quarenta e nove) adolescentes. A Tabela 2 mostra a composição do quadro de selecionadas no universo delimitado e o grupo de participantes.

Tabela 2 - Adolescentes com maternidades sucessivas selecionadas para a pesquisa em Rondonópolis-MT, 2007.

\begin{tabular}{lcc}
\hline Categorias & $\mathbf{N}$ & $\mathbf{\%}$ \\
\hline Não aceitaram participar. & 04 & 5,6 \\
\hline Não foram localizadas. & 04 & 5,6 \\
\hline Localizadas, mas não se enquadravam nos critérios. & 15 & 20,8 \\
\hline Participantes efetivas (N). & 49 & 68 \\
\hline Universo de selecionadas. & $\mathbf{7 3}$ & $\mathbf{1 0 0}$ \\
\hline
\end{tabular}


O número de adolescentes em cada grupo de participantes não foi homogêneo quanto ao número de filhos nascidos vivos e à gestação em que se encontravam, nem mesmo em proporções aproximadas. Contudo, o arranjo dado ao estudo não se pautou por análises que requeressem tal homogeneidade. A Tabela 3 apresenta os grupos de participantes conforme número de FNV e gestação em que se encontravam.

Tabela 3: Quantidade de FNV e gestação em que se encontravam adolescentes com maternidades sucessivas selecionadas para a pesquisa em Rondonópolis-MT, 2007.

\begin{tabular}{lcc}
\hline Número de filhos vivos e ordem da gravidez & $\mathbf{N}$ & $\mathbf{\%}$ \\
\hline 1 FNV e na 2 $2^{\mathrm{a}}$ gestação & 43 & 87 \\
\hline 2 FNV e na $3^{\mathrm{a}}$ gestação & 06 & 13 \\
\hline Total & $\mathbf{4 9}$ & $\mathbf{1 0 0}$ \\
\hline
\end{tabular}




\section{5 - DELINEAMENTO DO MÉTODO}

Penetra surdamente no reino das palavras. Lá estão os poemas que esperam ser escritos.

Estão paralisados, mas não há desespero, há calma e frescura na superficie intata. Ei-los sós e mudos, em estado de dicionário. Convive com teus poemas, antes de escrevê-los. Tem paciência, se obscuros. Calma, se te provocam.

Espera que cada um se realize e consume com seu poder de palavra e seu poder de silêncio.

Chega mais perto e contempla as palavras. Cada uma tem mil faces secretas sob a face neutra e te pergunta, sem interesse pela resposta, pobre ou terrivel que lhe deres:Trouxeste a chave?

Procura da Poesia - Carlos Drummond de Andrade

Trata-se de um estudo quanti-qualitativo, caracterizado por um método que articulou duas dimensões técnicas de coletas de informações: a descritiva (levantamento de informações em bancos de dados e aplicação de questionário sócio-econômico) e a narrativa (coleta de história de vida das participantes).

Desse modo, o estudo congregou três contextos presentes no fenômeno em tela:

a - o revelado pelos dados populacionais/reprodutivos;

b - os sócio-econômicos, e

c - o histórico da sexualidade/maternidades das adolescentes. 


\section{1 - FONTES, INSTRUMENTOS E TÉCNICAS}

\subsection{1 - Fontes}

A obtenção de dados secundários relativos à dinâmica reprodutiva da população adolescente brasileira foi feita por meio de consultas aos relatórios oficiais do Ministério da Saúde ${ }^{23,24}$ e ${ }^{26}$. Para a caracterização da dinâmica reprodutiva de adolescentes em Rondonópolis - MT e para os levantamentos de informações pertinentes à pesquisa que caracterizavam as condições específicas de ocorrência de gravidez e maternidade na população investigada foram acessados, no âmbito do município, o SINASC ${ }^{25}$ e o SISPRENATAL ${ }^{113}$.

\subsection{2 - Questionário}

Foi aplicado um questionário sócio-econômico com o intuito de realizar o levantamento de dados objetivos acerca das condições sócioeconômicas das 49 adolescentes. (Anexo I).

\subsection{3 - Entrevistas}

\subsubsection{1 - Entrevistas Abertas}

Foi realizada entrevista aberta individualizada com as 49 participantes com o objetivo de permitir que as adolescentes narrassem suas histórias de vida naquilo que se relacionavam com o despertar da sexualidade, com a gravidez e maternidade. Escolheu-se a entrevista aberta porque permite a partir de uma situação, necessidade ou mesmo de uma pergunta disparadora, que o entrevistado determine o quê, quando e como contar/revelar aspectos da sua história de vida. Permite ainda, que expresse como se relaciona, posiciona e representa suas experiências no mundo que o cerca. 
No âmbito das ciências sociais e, em especial, da antropologia da saúde, a entrevista aberta e o relato de histórias de vida são recursos que possibilitam a narrativa como técnica de pesquisa das metodologias de pesquisa qualitativa (MINAYO ${ }^{71}$, 1998; SILVA ${ }^{110}$, 2002; LIRA ${ }^{67}$ e col., 2003). A narrativa permite que as pessoas alinhavem suas experiências de vida, articulando o passado e o futuro com o olhar do presente (LABOV $\left.{ }^{63}, 1977\right)$, doando novos sentidos às experiências vividas, além de provocar novas reflexões sobre suas experiências subjetivas, podendo, até mesmo, alterar as perspectivas anteriores. (GOMES e col. $\left.{ }^{50}, 1999\right)$.

Há que se acrescentar que a comunicação não é linear. $O$ contar/narrar/revelar é também um infinito não contar/esconder e há que se ter ouvidos para o não dito. A comunicação é recheada de figuras de linguagem que requerem decifrações e possibilitam múltiplas interpretações. Diferentemente dos questionários, entrevistas abertas ou técnicas que se aproximam dessas, favorecem a livre expressão das histórias de vida e dos aspectos subjetivos a elas referentes e que se pretenda dizer/esconder.

Por isso, foi adotado como norteador das entrevistas, os princípios técnicos da entrevista aberta. Além da situação disparadora inicial, 'ser mãeadolescente com mais de um filho', tivemos vários outros temas que quando não contemplados no andamento espontâneo da entrevista, foram enunciados como novas situações provocadoras para a continuidade dos relatos. Tratou-se de buscar obter uma narração sobre a história de vida das adolescentes o mais próximo possível das dimensões configuradas por elas mesmas.

Os temas de antemão previsto foram os seguintes: 'relacionamento com a mãe e o pai', 'parceria amorosa', 'iniciação sexual', 'primeira gravidez', 'segunda ou mais gravidezes', ‘aborto', ‘trabalho', 'perspectivas para o futuro', 'cuidados com os filhos', 'relacionamento com os filhos', 'relacionamento com o(s) pai(s) dos filhos', 'escola', 'violência doméstica'. Entretanto, muitos outros surgiram e foram investigados no contexto da entrevista. 


\subsubsection{2 - Entrevistas Semi-estruturadas}

Toda entrevista aberta foi seguida pelo preenchimento de um roteiro de entrevista que continha a checagem de vários assuntos e detalhes que nem sempre eram abordados espontaneamente nas conversas abertas. Esse procedimento teve a intenção de uniformizar a coleta das informações. (Anexo II).

\subsection{4 - Pré-Teste e Registro das Informações}

Foi realizado pré-teste com o objetivo de experimentar e aprimorar o instrumental de coleta de dados. Foi aplicado o questionário sócio-econômico e realizada entrevista aberta e semi-estruturada com três mulheres com maternidades sucessivas, mas com idade entre 20 e 21 anos.

No pré-teste avaliou-se também a possibilidade de gravação dos procedimentos e optou-se por não realizá-la. Assim em todas as etapas da coleta de informações, o material foi registrado cursivamente segundo a informação colhida, de forma manuscrita. 


\section{2 - ANÁLISE DOS RESULTADOS}

Foi procedida uma análise quantitativa das informações obtidas nas

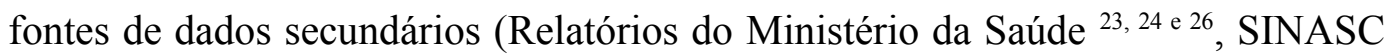
${ }^{25}$ e SISPRENATAL ${ }^{113}$ ) e pela aplicação do questionário sócio-econômico e entrevista semi-estruturada. De outro modo, as informações fornecidas pela entrevista aberta foram submetidas à análise qualitativa por meio da análise de conteúdo.

BARDIN ${ }^{99}$ (1979) diz que existem "dois tipos de documentos que podem ser submetidos à análise: documentos naturais, produzidos espontaneamente na realidade e documentos suscitados pelas necessidades de estudo (por exemplo: respostas aos questionários de inquéritos, testes, experiências, etc.)" (p.39). Sobre a análise de conteúdo, OLIVEIRA e col. ${ }^{79} \mathrm{diz}$ que:

Pode-se dizer que a análise de conteúdo é um conjunto de técnicas de exploração de documentos que procura identificar os principais conceitos ou principais temas abordados em determinado texto. Ela começa geralmente por uma leitura flutuante por meio da qual o pesquisador, num trabalho gradual de apropriação do texto, estabelece várias idas e vindas entre o documento analisado e as suas próprias anotações, até que comecem a emergir os contornos de suas primeiras unidades de registro ${ }^{79}$ (p. 06).

Tendo em vista essas considerações, a primeira etapa da análise pautou-se pela organização do material, transformando os resultados brutos em dados passíveis de operações como categorizações, classificações, relações, comparações, oposições, entre outras.

A segunda etapa tratou - a partir dos três contextos investigados - de caracterizar as áreas de encontros explicativos que envolvessem as maternidades sucessivas na adolescência, permitindo que sobressaíssem do conjunto de informações suas grandes linhas e principais regularidades. Desse modo, foi possível a definição das unidades/temáticas de registro ${ }^{79}$. Moscovici citado por OLIVEIRA e col. ${ }^{79}$ dizem que o tema 
é geralmente uma proposição tipo que exprime toda uma família de proposições tendo relação com um mesmo conteúdo diversamente formulado (...). Sua função é a de resumir o conteúdo (...) aparece como uma assertiva tornando possível um conteúdo variável. Ele constitui ao mesmo tempo uma relação na medida em que serve de mediador entre uma parte do conjunto com uma outra ${ }^{79}$ (p.09).

Assim, um tema pode surgir a partir de uma afirmação do texto ou estar contido de forma manifesta ou latente ao longo de uma passagem textual ou mesmo, numa alusão ou detalhe da narrativa. (D’UNRUG ${ }^{38}$, 1974). As ocorrências dessas unidades de registro formam temáticas que podem ser categorizadas, antecipadamente ou a posteriori, após a análise do material ${ }^{79}$.

A terceira etapa pautou-se pela construção de categorias de análise. Uma boa categoria contempla algumas qualidades como exclusão mútua, homogeneidade, pertinência, objetividade e produtividade ${ }^{09}$. Segundo OLIVEIRA e col. ${ }^{79}$, a categorização

gera classes que reúnem um grupo de elementos da unidade de registro. As classes são batizadas a partir da correspondência entre a significação, a lógica do senso comum e a orientação teórica do pesquisador (...) O sistema de categorização é composto por um reagrupamento progressivo de unidades de registro cuja amplitude varia de uma forte generalidade até uma generalidade fraca ${ }^{79}$ (p.8).

Finalmente, a quarta e última etapa da análise foi pautada pela interpretação dos dados quantitativos e sua inter-relação com as categorias obtidas por meio da análise de conteúdo, o que, caracterizou a discussão dos resultados e a conclusão da pesquisa. 


\section{6 - ASPECTOS ÉTICOS}

O projeto de pesquisa foi submetido ao Conselho de Ética em Pesquisa da Faculdade de Saúde Pública da USP, tendo recebido parecer favorável (Protocolo 1519/Ofício no. 272/06). Foi adotado um modelo único de TCLE Termo de Consentimento Livre e Esclarecido - (Anexo III), contendo um termo aditivo para que o responsável legal também autorizasse quando a participante tivesse menos de 18 anos. Nesses casos, a participante e o responsável assinaram.

O TCLE pautou-se, inicialmente, pelo esclarecimento dos objetivos da pesquisa, pelo convite à adolescente selecionada para que dela participasse de forma livre e voluntária e pela garantia de que poderia desistir de participar em qualquer uma das etapas, sem prejuízo algum para ambas as partes. Junto dessas informações, foram colocadas à disposição das participantes, as informações necessárias para, caso desejassem, tivessem condições de entrar em contato com o pesquisador ou seu orientador.

Em seguida, esclareceu-se sobre a forma, tempo e local de coleta das informações e de que não estavam previstos benefícios diretos, despesas financeiras ou malefícios por participarem da pesquisa. Foi também informado às convidadas no TCLE, que, se por ventura, algum incômodo emocional thes fossem acarretados em decorrência da pesquisa, elas poderiam se beneficiar de atendimento psicológico em centro especializado público. Garantiu-se, também, o sigilo sobre suas identidades e informações privadas que permitissem a identificação quando oferecidas ao pesquisador.

Por fim, o TCLE esclareceu sobre o zelo e guarda dos materiais, do acesso aos resultados da pesquisa e da necessidade do responsável legal, de igual forma, consentir a participação, caso tivessem menos de 18 anos de idade. 
CAPÍTULO III

ENCONTROS E DESENCONTROS 


\section{7 - APRESENTAÇÃO DOS RESULTADOS}

O levantamento de várias informações que se seguem exigiu cuidado. Se para algumas adolescentes percebíamos que abordar alguns assuntos não thes constrangia, para outras, muitos temas eram delicados e requereu sensibilidade para abordá-los. Respeitar os limites de cada participante, deixar a conversa fluir, investigar outro tema e, no momento oportuno, usar o instrumento mais adequado e pautar as questões mais delicadas foi o jeito encontrado.

Algumas informações objetivas, especialmente às relativas aos acontecimentos ocorridos numa ordem cronológica escapam da memória, não resistem ao tempo. A lógica de se trabalhar resgatando as estórias de vida ou de parte da existência pareceu romper com a idéia de uma verdade histórica, que se conservaria tal como ocorrida. Por exemplo, investigar a idade de ocorrência da menarca, por simples que se pareça, não foi. Aline disse: "acho que foi com onze anos, não, foi com doze, 'pera aí' eu ia fazê treze”.

As histórias contadas pelas adolescentes, muitas vezes, continham imprecisões, destacadas por elas mesmas, que aos poucos nos tiraram as últimas pretensões para com as médias aritméticas. Por isso, escolhemos trabalhar com categorias relativamente amplas, de modo que comportassem as imprecisões, os esquecimentos, os 'não-ditos', mas que, por outro lado, permitissem observar "pontos de concentração" dos fenômenos. Esse posicionamento justificou também que escolhêssemos exprimir as intensidades, quantidades e freqüências por meio de porcentagens.

Assim, o arranjo textual concedido à apresentação dos resultados segue, inicialmente, as informações referentes à dinâmica reprodutiva de adolescentes no Brasil e em Rondonópolis-MT. Em seguida, descrevemos os resultados atinentes às condições sócio/culturais e econômicas.

Finalmente, dispomos os dados alusivos à história sexual e reprodutiva das participantes da pesquisa. Contudo, a explanação dos resultados não conseguiu acatar ao rigor e esforço com que didaticamente acima 
descrevemos a intenção. Há variações, idas e vindas na apresentação que entrelaçam os resultados e que parecem refletir a própria essência deles. 


\section{1 - A DINÂMICA REPRODUTIVA DA POPULAÇÃO}

ADOLESCENTE DE RONDONÓPOLIS-MT NO PERÍODO 2000/2006

Embora com restrições, a Secretaria Municipal de Saúde de Rondonópolis-MT permitiu o acesso a vários dados do SINASC ${ }^{25}$, o que nos possibilitou caracterizar alguns aspectos da dinâmica reprodutiva da população adolescente nos últimos anos. A Tabela 4 mostra a evolução ao longo desses anos do número de FNV em adolescentes, de 15 a 19 anos, que já tinham um ou mais FNV, em relação ao total de FNV em toda a população do município.

Tabela 4 - FNV em adolescentes (15 a 19 anos) com dois ou mais FNV em relação ao total de FNV na população de Rondonópolis-MT - 2000 a 2006.

\begin{tabular}{cccccccc}
\hline $\begin{array}{c}\text { FNV } \\
\text { Adolescentes de } \\
\mathbf{1 5 - 1 9} \text { anos }\end{array}$ & $\mathbf{2 0 0 0}$ & $\mathbf{2 0 0 1}$ & $\mathbf{2 0 0 2}$ & $\mathbf{2 0 0 3}$ & $\mathbf{2 0 0 4}$ & $\mathbf{2 0 0 5}$ & $\mathbf{2 0 0 6}$ \\
\hline $\begin{array}{c}\text { \% FNV em } \\
\text { adolescentes com } \\
\text { mais de 1 FNV }\end{array}$ & 7,6 & 7,5 & 7,3 & 4,6 & 6,1 & 5,3 & 4,6 \\
\hline $\begin{array}{c}\text { Total de FNV em } \\
\text { adolescentes com } \\
\text { mais de 1 FNV }\end{array}$ & 228 & 228 & 196 & 170 & 184 & 175 & 129 \\
\hline $\begin{array}{c}\text { Total FNV na } \\
\text { população geral }\end{array}$ & 3010 & 3039 & 2696 & 2736 & 3011 & 3303 & 3128 \\
\hline
\end{tabular}

Fonte: SINASC/ Secretaria Municipal de Saúde de Rondonópolis-MT, $2007^{25}$

O que se observou é que embora os valores absolutos flutuem ao longo dos anos conforme a variação do aumento populacional (aparentemente também determinado pelo aumento ou estabilização dos fluxos migratórios), os percentuais de adolescentes com FNV pela segunda ou mais vezes representou em relação ao total de FNV na população geral, 7,6\% no ano 2000, e caiu para 4,6\%, em 2006, caracterizando uma trajetória de considerável queda nos últimos anos.

Fazendo outra comparação, a Tabela 5 apresenta $\mathrm{o}$ quanto os percentuais de FNV de adolescentes com maternidades sucessivas representaram na composição do total de FNV entre adolescentes. Novamente observamos o registro de considerável queda no período 2000/2006. 
Tabela 5 - FNV em adolescentes (15 a 19 anos) com dois ou mais FNV em relação ao total de FNV na população adolescente de Rondonópolis-MT - 2000 a 2006.

\begin{tabular}{cccccccc}
\hline Faixas Etárias & $\mathbf{2 0 0 0}$ & $\mathbf{2 0 0 1}$ & $\mathbf{2 0 0 2}$ & $\mathbf{2 0 0 3}$ & $\mathbf{2 0 0 4}$ & $\mathbf{2 0 0 5}$ & $\mathbf{2 0 0 6}$ \\
\hline $\begin{array}{c}\text { Total FNV na } \\
\text { população } \\
\text { adolescente }\end{array}$ & 228 & 228 & 196 & 170 & 184 & 175 & 129 \\
\hline $\begin{array}{c}\text { \% FNV em } \\
\text { adolescentes }\end{array}$ & 26,8 & 25,5 & 26,8 & 22,8 & 24,7 & 21,3 & 19,0 \\
\hline
\end{tabular}

Fonte: SINASC / Secretaria Municipal de Saúde de Rondonópolis-MT, $2007^{25}$

Essa queda pareceu relacionar-se diretamente à considerável diminuição dos percentuais de FNV de adolescentes (10 a 19 anos) em relação ao total de FNV em toda a população ocorrida no município durante o período 2001/2006, conforme apresentado na Tabela 6. Em 2001, atingiu 29,2\% e em $2006,23,8 \%$.

Tabela 6 - Evolução de FNV em adolescentes conforme faixa etária em relação ao total de FNV no restante da população de Rondonópolis-MT - 2000 a 2006.

\begin{tabular}{cccccccc}
\hline Faixas Etárias & $\mathbf{2 0 0 0}$ & $\mathbf{2 0 0 1}$ & $\mathbf{2 0 0 2}$ & $\mathbf{2 0 0 3}$ & $\mathbf{2 0 0 4}$ & $\mathbf{2 0 0 5}$ & $\mathbf{2 0 0 6}$ \\
\hline $\begin{array}{c}\text { \% FNV em } \\
\text { menores de 15 anos }\end{array}$ & 1,0 & 0,9 & 1,4 & 0,9 & 1,0 & 1,0 & 1,1 \\
\hline $\begin{array}{c}\text { \% FNV em } \\
\text { Adolesc. }\end{array}$ & 27,1 & 28,3 & 25,5 & 26,2 & 23,6 & 23,7 & 22,7 \\
\hline $\begin{array}{c}\text { Adolescentes de 15 a 19 anos } \\
\text { \% Total FNV em }\end{array}$ & 12,1 & 29,2 & 26,9 & 27,1 & 24,6 & 24,7 & 23,8 \\
\hline Adolescentes de 10 a 19 anos & 28,1
\end{tabular}

Fonte: SINASC / Secretaria Municipal de Saúde de Rondonópolis-MT, $2007^{25}$

Observou-se também que os filhos vivos nascidos de mães de 15 a 19 anos, representaram no total de nascimentos, 27,1\% em 2000, e 22,7\%, em 2006, o que permitiu afirmar que houve uma considerável redução no número de nascidos vivos em mulheres dessa faixa etária no período. Entretanto, entre 2000/2006, na faixa etária 'menores de 15 anos', houve um ligeiro aumento do percentual de FNV. Saltou de 1\% no ano 2000 para um pico, em 2002, de 1,4\% e retornou, em 2006, a um patamar, pouco acima da média do período, 1,1\%.

De outro modo, a Tabela 7 apresenta o quanto que os percentuais de FNV por faixa etária de adolescentes representam na composição do total de FNV 
entre adolescentes. A informação deixa mais saliente o quanto vem aumentando a proporção dos FNV de 'menores de 15 anos'.

Tabela 7 - FNV em adolescentes conforme faixa etária na população adolescente de Rondonópolis-MT - 2000 a 2006.

\begin{tabular}{cccccccc}
\hline Faixas Etárias & $\mathbf{2 0 0 0}$ & $\mathbf{2 0 0 1}$ & $\mathbf{2 0 0 2}$ & $\mathbf{2 0 0 3}$ & $\mathbf{2 0 0 4}$ & $\mathbf{2 0 0 5}$ & $\mathbf{2 0 0 6}$ \\
\hline $\begin{array}{c}\text { \% FNV em Adolesc. } \\
\text { menores de 15 anos }\end{array}$ & 3,6 & 3,3 & 5,5 & 3,3 & 4,2 & 4,2 & 4,6 \\
\hline $\begin{array}{c}\text { \% FNV em Adolesc. } \\
\text { de 15 a 19 anos }\end{array}$ & 96,4 & 96,3 & 94,5 & 96,6 & 95,8 & 95,8 & 95,4 \\
\hline $\begin{array}{c}\text { \% Total FNV em } \\
\text { Adolesc. de 10 a 19 anos }\end{array}$ & $\mathbf{1 0 0}$ & $\mathbf{1 0 0}$ & $\mathbf{1 0 0}$ & $\mathbf{1 0 0}$ & $\mathbf{1 0 0}$ & $\mathbf{1 0 0}$ & $\mathbf{1 0 0}$ \\
\hline
\end{tabular}

Fonte: SINASC / Secretaria Municipal de Saúde de Rondonópolis-MT, $2007^{25}$.

Pareceu colaborar para a queda dos percentuais de segunda ou mais maternidades na adolescência, o aumento da escolaridade das adolescentes que ficaram mães no período 2000/2006. O que se constatou nesse período, conforme apresentado na Tabela 8 é que houve uma diminuição do percentual de FNV de adolescentes com baixa escolaridade e, consequentemente, aumentou o percentual de novas maternidades entre aquelas com maior escolaridade.

Tabela 8 - FNV em adolescentes (10 a 19 anos) segundo escolaridade no município de Rondonópolis-MT - 2000 a 2006.

\begin{tabular}{cccccccc}
\hline Escolaridade & $\mathbf{2 0 0 0}$ & $\mathbf{2 0 0 1}$ & $\mathbf{2 0 0 2}$ & $\mathbf{2 0 0 3}$ & $\mathbf{2 0 0 4}$ & $\mathbf{2 0 0 5}$ & $\mathbf{2 0 0 6}$ \\
\hline Nenhuma & 0,6 & 0,7 & 1,0 & 0 & 0,5 & 0,2 & 0,5 \\
\hline $1-3$ anos & $\mathbf{7 , 3}$ & 7,9 & 9,6 & 4,7 & 4,3 & 2,5 & $\mathbf{2 , 8}$ \\
\hline $4-7$ anos & $\mathbf{5 6 , 7}$ & 52,3 & 49,5 & 42,7 & 44,0 & 40,0 & $\mathbf{3 1 , 8}$ \\
\hline $8-11$ anos & $\mathbf{3 0 , 4}$ & 36,4 & 35,5 & 39,3 & 40,0 & 46,6 & $\mathbf{6 2 , 6}$ \\
\hline 12 e + anos & 5,0 & 2,7 & 4,4 & 13,3 & 11,2 & 10,7 & 2,1 \\
\hline Total & 100 & 100 & 100 & 100 & 100 & 100 & 100 \\
\hline \multicolumn{7}{c}{ Fonte: SINASC / Secretaria Municipal de Saúde de Rondonópolis-MT, $2007^{25}}$.
\end{tabular}

Embora essa análise pareça contraditória, o que parece ter ocorrido, foi que as maternidades que no ano 2000 ocorriam, predominantemente $(56,7 \%)$ entre as adolescentes que tinham de 4 a 7 anos de escolaridade, migraram para outra faixa etária da adolescência, ocorrendo sua maior concentração (62,6\%), em 2006, entre as adolescente com 8 a 11 anos de escolarização. 
Essas informações sugerem que houve um adiamento das gravidezes, $o$ que em tese, colaborou para a diminuição da segunda ou mais maternidades ainda na adolescência. Indícios do retardamento da vida reprodutiva na população local puderam ser identificados também quando se analisou os percentuais de FNV de mães com idade entre 20 e 34 anos, que representavam em 2000, 68,0\% do total de nascimentos ocorridos na população e em 2006, subiu para $70,2 \%$.

O mesmo se verificou com o percentual de FNV de mães com idade acima de 35 anos. Em 2000, representavam 3,8\% do total de nascimentos do município, mas em 2006, saltou para 5,8\%, o que permite afirmar que houve um aumento considerável da proporção de FNV em mulheres acima dos 35 anos nesses anos.

Provavelmente, a melhoria das condições de vida do município começou a exercer pressão contrária à juvenização da maternidade, o que empurrou os nascimentos para faixas etárias mais tardias. Embora esses resultados pareçam contraditórios ao fato de que entre as adolescentes menores de 15 anos houve um ligeiro aumento da proporção do número de FNV, é possível admitir que os dois fenômenos - retardamento e juvenescimento da maternidade - estejam ocorrendo simultaneamente e caracterizando grupos de mulheres com dinâmicas reprodutivas relativamente diferentes.

O tipo de parto realizado pelas adolescentes no período 2000/2006 manteve-se estabilizado ao longo dos anos, conforme exposto na Tabela 9, apresentando pequenas oscilações, mas sempre mantendo a proporção de um parto cesáreo para cada dois vaginais.

Tabela 9 - Tipo de parto realizado em adolescentes (10 a 19 anos) com FNV em Rondonópolis-MT-2000 a 2006.

\begin{tabular}{cccccccc}
\hline Tipo de Parto & $\mathbf{2 0 0 0}$ & $\mathbf{2 0 0 1}$ & $\mathbf{2 0 0 2}$ & $\mathbf{2 0 0 3}$ & $\mathbf{2 0 0 4}$ & $\mathbf{2 0 0 5}$ & $\mathbf{2 0 0 6}$ \\
\hline Parto Vaginal (\%) & 64 & 71 & 68 & 66 & 67 & 69 & 66 \\
\hline Parto Cesáreo (\%) & 36 & 29 & 32 & 34 & 33 & 31 & 34 \\
\hline Total & $\mathbf{1 0 0}$ & $\mathbf{1 0 0}$ & $\mathbf{1 0 0}$ & $\mathbf{1 0 0}$ & $\mathbf{1 0 0}$ & $\mathbf{1 0 0}$ & $\mathbf{1 0 0}$ \\
\hline
\end{tabular}

Fonte: SINASC / Secretaria Municipal de Saúde de Rondonópolis-MT, $2007^{25}$. 


\section{2 - CONTEXTO SÓCIO-ECONÔMICO DAS ADOLESCENTES}

Bebida é água, comida é pasto. Você tem sede de quê?

Você tem fome de quê? A gente não quer só comida

A gente quer comida, diversão e arte

A gente não quer só comida, a gente quer saída para qualquer parte

A gente não quer só comida, a gente quer bebida, diversão, balllet A gente não quer só comida, a gente quer a vida como a vida quer A gente não quer só comer, a gente quer comer e quer fazer amor A gente não quer só comer, a gente quer prazer pra aliviar a dor A gente não quer só dinheiro, a gente quer dinheiro e quer felicidade A gente não quer só dinheiro, a gente quer inteiro e não pela metade Desejo, necessidade, vontade, necessidade, desejo, necessidade, vontade, Desejo, necessidade, vontade, necessidade, desejo, necessidade, vontade.

Comida - Titãs

\subsection{1 - Acesso à Moradia}

O geoprocessamento da localização das residências das adolescentes permitiu identificar e visualizar a forma de distribuição geográfica da ocorrência de maternidades sucessivas no tecido urbano (Anexo IV). O dado revelou que todas as adolescentes participantes residiam em bairros pobres e periféricos à região central da cidade.

$\mathrm{Na}$ caracterização desses bairros se observou que possuíam certa organização na disponibilizarão de alguns recursos, como supermercado, padaria, posto bancário, núcleo de saúde da família, asfalto, linhas de ônibus, entre outros. Entretanto, foi possível observar que não era nessa região do bairro que as participantes da pesquisa residiam. Elas moravam para além desses recursos, no "fim da vila", "no fim da rua", em lugares de difícil acesso, próximos aos rios e riachos, em moradias precárias e improvisadas, condição a que convimos chamar de "morar na periferia da periferia".

Em 22,4\% dos casos, as adolescentes nomearam suas residências de "barraco" e 4,1\% de "cômodo". Em 20,4\% das moradias, o material que predominava na edificação eram restos de madeira e em $2,1 \%$, eram lonas 
plásticas. Em 36,7\% das residências havia de um a três cômodos. Em 38,8\% dos domicílios, dois cômodos eram usados permanentemente como dormitórios.

Esses índices só não foram maiores porque em torno de quinze adolescentes ou seus familiares eram beneficiários de políticas públicas. Essas ações governamentais se pautam pela doação de pequenas casas às famílias que, em outrora, ocupavam áreas alheias. Essa é uma prática muito comum na cidade e são chamadas de "grilo" v. No entanto, essas casas são apenas pré-construídas com infra-estrutura mínima e após a doação, os ocupantes devem terminar a construção, instalando portas internas, reboco, forração e outros acabamentos.

Embora esses programas urbanizem os "grilos", a pobreza permanece. A pobreza persistia também entre as adolescentes que residiam em casas construídas em regime de mutirões por instituições filantrópicas (Cáritas) - cinco moravam em casas assim construídas - e mesmo entre aquelas, cujas famílias ou parceiros, possuíam casa própria. Em cerca de doze residências, apesar de recém construídas e ocupadas, as pessoas estavam sem mobiliário algum, com água e luz "cortadas" e sem gêneros alimentícios.

De outra forma, encontramos quatro "proprietárias" de casa própria, mas residiam em bairros com baixa densidade demográfica e por isso, eram regiões privadas de uma porção de benefícios. A tabela 10 demonstra o tipo de vínculo que as adolescentes mantinham com o domicílio.

Tabela 10 - Vínculo mantido com o domicílio por adolescentes com maternidades sucessivas em Rondonópolis-MT, 2007.

\begin{tabular}{lcc}
\hline Tipo de Vínculo & N & \% \\
\hline Da família/parceiro & 28 & 57,2 \\
\hline Alugado & 12 & 24,5 \\
\hline Cedido & 08 & 16,3 \\
\hline Total & $\mathbf{4 9}$ & $\mathbf{1 0 0}$ \\
\hline
\end{tabular}

\footnotetext{
v Os "grilos" contam com um considerável grau de organização e reúnem múltiplos interesses, desde o proprietário da terra invadida que se beneficia ao ser desapropriado pelo poder público, o líder comunitário que, por sua vez, está atrelado a lideranças políticas, os próprios políticos que manipulam as situações de modo a transformar o novo bairro em curral eleitoral, as construtoras que constroem as casas e o próprio beneficiário do programa, que "tem um lugar prá mora", mas, por vezes, alugam ou mesmo "vendem o direito" ao lar.
} 
A ocupação do cerrado e sua transformação em espaço urbano ocorreram, durante muitos anos, por meio de empreendimentos imobiliários irregulares, sustentados pela simples venda de terrenos sem nenhuma infraestrutura e ordenamento urbano. Isso produziu enormes vazios habitacionais na cidade, que sustentam a especulação imobiliária e dificultam a extensão dos serviços públicos.

Apesar disso, em 100\% dos domicílios das adolescentes existia água encanada, luz elétrica e coleta de lixo. Toda a água distribuída na cidade é tratada, mas, considerando que há outras fontes de contaminação da água após o seu tratamento, preocupou a informação que em 71,4\% dos domicílios dessas mães não existiam filtros de água.

Quanto à coleta do esgoto, todas as residências eram servidas por fossas e, portanto, não estavam conectados à rede coletora de esgoto e emissário para estação de tratamento. Em alguns pontos o esgoto estava lançado a céu aberto e com despejo in natura nos mananciais de água. Há um problema estrutural no município, pois apenas em alguns bairros centrais há a coleta e tratamento dos efluentes, o que gera inúmeros problemas de saúde e ambientais, como a contaminação do solo e do lençol freático.

Quanto à organização familiar, são inúmeras as formas de agrupamentos em que estavam inseridas as adolescentes. Em parte, cerca de 30\%, eram constituídos por famílias nucleares tradicionais e, em outra, cerca de $60 \%$, se caracterizavam por congregarem pessoas ligadas à família de origem, como pai, mãe, sogro, sogra, irmãos e também, outros familiares mais distantes, como primos, cunhados, tios, tias, sobrinhos.

Encontramos ainda cerca de $10 \%$ de agrupamentos mistos em que se juntavam outros convivas, como amigos e conhecidos, os quais chamam de "república" e/ou "quitinetes". A Tabela 11 apresenta os percentuais da quantidade de pessoas que coabitavam o mesmo domicílio.

O acesso a bens domésticos, como fogão a gás, estava presente a 100\% dos domicílios investigados, embora fosse relativamente comum observar a 
existência de fogões à lenha, usados para "cozinhá feijão e fervê roupa porque gasta muito gás", conforme explicou Sara. Em 85,7\% dessas residências havia geladeira e, em 63,3\% máquinas de lavar roupa.

Tabela 11 - Pessoas residentes por domicílio com adolescentes com maternidades sucessivas em Rondonópolis-MT, 2007.

\begin{tabular}{lcc}
\hline Número de Pessoas & N & \% \\
\hline Até 3 pessoas & 21 & 42,8 \\
\hline De 4 a 6 pessoas & 24 & 49,0 \\
\hline Acima de 7 pessoas & 4 & 8,2 \\
\hline Total & $\mathbf{4 9}$ & $\mathbf{1 0 0}$ \\
\hline
\end{tabular}

Os meios de comunicação, como telefone fixo foi encontrado em $6 \%$ das casas; telefones celulares em $54,2 \%$; aparelhos televisivos em $87,7 \%$ e rádios em 57,2\%. Em nenhuma residência existia microcomputador.

A locomoção era feita, predominantemente, por motos-táxis, meio de transporte consideravelmente mais caro e perigoso que o transporte coletivo, embora esse também fosse utilizado. Em 20,4\% dos domicílios das adolescentes, algum morador possuía um veículo automotivo, geralmente, moto. Aliás, um dos grandes problemas de saúde pública do município se refere justamente aos acidentes de trânsito decorrentes do uso das motocicletas.

\subsection{2 - Acesso à Renda}

A respeito das características de acesso à renda, $26,5 \%$ das adolescentes fez algum curso profissionalizante, mas mesmo entre essas, percebeu-se que foram cursos incipientes, incapazes de oferecer-lhes qualificação para o mercado de trabalho formal. Referiram terem sido beneficiadas por algum tipo de programa governamental de distribuição de renda para si ou filhos, $42,8 \%$ das adolescentes.

Geralmente, o trabalho remunerado que tiveram foi de ajudante de manicure, babá ou doméstica. A informalidade é tão grande que chega a 75,5\% o percentual daquelas que já tiveram trabalho remunerado, mas a $100 \%$ a 
dependência à renda de outras pessoas após a gravidez, ou seja, estavam todas desempregadas e sem renda no momento da nova maternidade. A Tabela 12 apresenta as faixas de renda mensal daqueles de quem dependiam.

Tabela 12 - Rendimento mensal dos provedores de adolescentes com maternidades sucessivas em Rondonópolis-MT, 2007.

\begin{tabular}{lcc}
\hline Salário(s) & $\mathbf{N}$ & $\mathbf{\%}$ \\
\hline 0 & 01 & 2,1 \\
\hline 0,5 & 04 & 8,1 \\
\hline 1 & 22 & 44,9 \\
\hline 1,5 & 05 & 10,2 \\
\hline 2 & 14 & 28,5 \\
\hline 3 & 2 & 4,1 \\
\hline 4 ou mais & 1 & 2,1 \\
\hline Total & $\mathbf{4 9}$ & $\mathbf{1 0 0}$ \\
\hline
\end{tabular}

As informações permitiram constatar que 55,1\% das adolescentes dependiam de provedores que tinham rendas de no máximo um salário mínimo e apenas 6,2\% de provedores com renda maior a três salários. Quando se considerou a renda do grupo que compartilhavam o mesmo domicílio, houve o aumento do percentual de gestantes onde o grupo com o qual conviviam não tinha nenhuma renda, $8,1 \%$, mas, diminuiu o percentual daquelas que dependiam de rendas menores de dois salários. Consequentemente aumentou para 30,6\%, o percentual daquelas que puderam se beneficiar de rendas maiores que três salários, conforme apresentado na a Tabela 13.

Tabela 13 - Total da renda das pessoas com as quais convivem adolescentes com maternidades sucessivas em Rondonópolis-MT, 2007.

\begin{tabular}{lcc}
\hline Salário(s) & $\mathbf{N}$ & $\mathbf{\%}$ \\
\hline 0 & 04 & 8,1 \\
\hline 0,5 & 01 & 2,1 \\
\hline 1 & 16 & 32,7 \\
\hline 1,5 & 05 & 10,2 \\
\hline 2 & 08 & 16,3 \\
\hline 3 & 08 & 16,3 \\
\hline Mais de 4 & 07 & 14,3 \\
\hline Total & $\mathbf{4 9}$ & $\mathbf{1 0 0}$ \\
\hline
\end{tabular}


A Tabela 14 apresenta a condição das adolescentes em relação ao responsável pelo domicílio, que, geralmente, era de quem dependiam, principalmente, quando estavam na condição de esposa e de filha.

Tabela 14 - Vínculo mantido entre adolescentes com maternidades sucessivas e o responsável pelo domicílio em Rondonópolis-MT, 2007.

\begin{tabular}{lcc}
\hline Tipo de Vínculo & $\mathbf{N}$ & $\mathbf{\%}$ \\
\hline Esposa & 23 & 47 \\
\hline Filha & 10 & 20,4 \\
\hline Nora & 6 & 12,2 \\
\hline Conhecida & 5 & 10,2 \\
\hline Irmã & 2 & 4,1 \\
\hline Outro & 3 & 6,1 \\
\hline Total & $\mathbf{4 9}$ & $\mathbf{1 0 0}$ \\
\hline
\end{tabular}

Nessas circunstâncias, a composição da renda do grupo familiar esteve diretamente associada ao número de pessoas trabalhando e, embora em 57,2\% dos domicílios, morasse mais de quatro pessoas, apenas uma estava trabalhando em 47\% deles, conforme é apresentado na Tabela 15.

Tabela 15 - Pessoas que trabalham residentes em domicílio com adolescentes com maternidades sucessivas em Rondonópolis-MT, 2007.

\begin{tabular}{lcc}
\hline Quantidade & $\mathbf{N}$ & $\mathbf{\%}$ \\
\hline nenhuma & 7 & 14,3 \\
\hline 1 & 23 & 47 \\
\hline 2 & 9 & 18,4 \\
\hline 3 & 7 & 14,2 \\
\hline 4 ou mais & 3 & 6,1 \\
\hline Total & $\mathbf{4 9}$ & $\mathbf{1 0 0}$ \\
\hline
\end{tabular}

\subsection{3 - Acesso à Educação}

No que se refere ao acesso à educação, 10,2\% referiram ter ficado alguma vez na vida escolar sem estudar por falta de vagas na escola. Entretanto, vários outros aspectos foram apontados como determinantes para o abandono da escola, como a "gravidez", "mudanças" da família de emprego, de cidade, de endereço, "preguiça", "bagunça", "trabalho". Das participantes, apenas 2,1\% 
permaneciam estudando. Não tinham concluído o primário $10,2 \%$ e, apenas 22,5\% concluíram o ginasial. Nenhuma concluiu o ensino médio. A Tabela 16 demonstra os percentuais de adolescentes conforme seus anos de escolaridade.

Tabela 16 - Escolaridade de adolescentes com maternidades sucessivas em Rondonópolis-MT, 2007.

\begin{tabular}{lcc}
\hline Ano(s) & $\mathbf{N}$ & $\mathbf{\%}$ \\
\hline 1 & 02 & 4,1 \\
\hline 2 & - & - \\
\hline 3 & 03 & 6,1 \\
\hline 4 & 09 & 18,4 \\
\hline 5 & 03 & 6,1 \\
\hline 6 & 10 & 20,4 \\
\hline 7 & 11 & 22,4 \\
\hline 8 & 08 & 16,3 \\
\hline 9 & 01 & 2,1 \\
\hline 10 & 02 & 4,1 \\
\hline Total & $\mathbf{4 9}$ & $\mathbf{1 0 0}$ \\
\hline
\end{tabular}

$\mathrm{O}$ percentual de adolescentes que em algum momento de suas vidas escolares repetiu alguma série chegou a 65,3\%. Entre essas, 21,9\% repetiu mais de uma vez. Houve um considerável percentual de repetências na $1^{\mathrm{a}}$ série, o que as jovens atribuíram às constantes mudanças de locais de trabalho da família, principalmente, entre aquelas cujo pai trabalhava de "peão" de fazenda, trabalho muito comum na região e caracterizado por grande instabilidade no emprego.

Tabela 17 - Repetência escolar entre adolescentes com maternidades sucessivas em Rondonópolis-MT, 2007.

\begin{tabular}{lcc}
\hline Série & $\mathbf{N}$ & $\mathbf{\%}$ \\
\hline $1^{\mathrm{a}}$ & 08 & 25,0 \\
\hline $2^{\mathrm{a}}$ & 02 & 6,2 \\
\hline $3^{\mathrm{a}}$ & 04 & 12,5 \\
\hline $4^{\mathrm{a}}$ & 00 & 00 \\
\hline $5^{\mathrm{a}}$ & 07 & 22,0 \\
\hline $6^{\mathrm{a}}$ & 06 & 18,8 \\
\hline $7^{\mathrm{a}}$ & 02 & 6,2 \\
\hline $8^{\mathrm{a}}$ & 02 & 6,2 \\
\hline $1^{\mathbf{o}}$ Colegial & 01 & 3,1 \\
\hline Total & $\mathbf{3 2}$ & $\mathbf{1 0 0}$ \\
\hline
\end{tabular}

Há grande rotatividade nesse tipo de emprego e as famílias perambulam de fazenda em fazenda não vinculando seus filhos à escola, 
principalmente, nas séries iniciais, quando são muito dependentes. Contudo, conforme apresentado na Tabela 17, a maior proporção de adolescentes repetentes concentrou-se na $1^{\mathrm{a}}, 5^{\mathrm{a}}$ e $6^{\mathrm{a}}$ série, quando vários outros motivos parecem entrar em cena, inclusive, a maternidade.

\subsection{4 - Acesso à Saúde}

Todas as participantes haviam feito pré-natal na gestação do primeiro filho e todas estavam fazendo na gestação em que se encontrava. $\mathrm{O}$ que variou, foi o tempo para descobrirem-se grávidas e o tempo que após, saberem da gravidez, levaram para iniciar o pré-natal. Contudo, comentários das agentes de saúde denotaram que uma ou outra não estavam fazendo pré-natal como deveria embora a gravidez estivesse avançada.

Quanto aos cuidados básicos recebidos pelas adolescentes no pré-natal, $28,6 \%$ referiu ter ficado, em algum momento, sem consulta médica. Entretanto, avaliaram como 'muito bom' o atendimento médico realizado no pré-natal, $78,3 \%$. Analisaram como 'regular' 6,5\% e, como 'ruim' 15,2\%. O atendimento prestado pelo enfermeiro no pré-natal foi avaliado por 93,9\% como 'muito bom' e, por $6,1 \%$, como 'regular'.

Contudo, os serviços prestados pelos agentes de saúde e pelos atendentes das unidades básicas de saúde não são tão bem avaliados, em parte, porque, provavelmente, apresentam problemas, mas noutra, porque é com esses profissionais que a população mais interage na busca de informações e recursos.

Ou seja, de certa forma, em suas salas de atendimento climatizadas, alguns profissionais ficam protegidos dos dramas diários da população e daqueles dos próprios serviços de saúde. Nem sempre o calor das ruas e salas de espera os incomoda. Entre as adolescentes, 6,1\% avaliaram o serviço realizado pelos agentes de saúde como 'regular' e 6,1\% como 'ruim'. Quanto ao acolhimento realizado pelos atendentes de saúde, 18,4\% consideraram-no 'regular' e 8,1\% como 'ruim'. Qualitativamente, a queixa refere-se, de maneira geral, à "falta de educação" desses profissionais. 
Quanto à territorialização dos serviços de saúde, 28,6\% consideraram que a unidade de saúde está bem localizada e próxima à sua residência, entretanto, 55,2\% avaliou que ela se encontra 'muito distante' e 10,2\% 'pouco distante'.

As informações coletadas revelaram que o acesso e a realização do pré-natal são relativamente eficientes nas áreas cobertas pelo Programa Saúde da Família, que no município, tem abrangência de 65\%. Nas áreas sem essa referência verificamos que o acesso é restrito às consultas médicas e ocorrem em menor número. Essas áreas são cobertas por Centros e Postos de Saúde. A Tabela 18 apresenta informações relativas ao número de consultas médicas por pré-natal em cada gestação.

Tabela 18 - Adolescentes com maternidades sucessivas conforme número de consultas médicas no pré-natal por gestação em Rondonópolis-MT, 2007.

\begin{tabular}{lcc}
\hline $\begin{array}{c}\text { Número de consultas } \\
\text { médicas }\end{array}$ & $\begin{array}{c}\text { \% de Gestantes } \\
\text { Primeira Gestação }\end{array}$ & $\begin{array}{c}\text { \% de Gestantes } \\
\text { Segunda Gestação }\end{array}$ \\
\hline 2 & 2,0 & - \\
\hline 3 & 4,1 & 16,6 \\
\hline 4 & 14,3 & 50 \\
\hline 5 & 6,1 & 16,6 \\
\hline 6 & 18,4 & - \\
\hline 7 & 47,0 & 16,6 \\
\hline 8 e acima & 8,1 & $\mathbf{1 0 0}$ \\
\hline Total & $\mathbf{1 0 0}$ & \\
\hline
\end{tabular}

Chamou atenção que enquanto na primeira gestação, 55,1\% freqüentou sete ou mais consultas médicas, na segunda, apenas 16,6\% assim fizeram. Ou seja, parece existir a indicação de que a freqüência ao pré-natal, quando garantido o acesso, depende também de outros aspectos da vida das adolescentes, dos quais, destacamos os subjetivos.

A experiência do primeiro filho parece propiciar-lhes certa autonomia para vivenciar e administrar a nova maternidade com maior segurança e autonomia, muito embora, cada gravidez tenha lá suas peculiaridades. Um exemplo marcante e que parece motivar o início do pré-natal refere-se aos enjôos, náuseas e vômitos, presentes, geralmente, até o terceiro mês de gestação. 
Na primeira gestação, parece que atribuem ao médico a tarefa de curálas de tamanho mal-estar, mas ao descobrirem a 'normalidade' do desassossego, parecem decepcionadas. A esse respeito, Santina disse: "eu tinha muito enjôo, fui no médico, mas ele não fez nada, disse que é normal e que tenho que agüentar".

Outro aspecto que se destaca e que torna o número de consultas médicas um indicador relativo é o fato de que nas Unidades de Saúde da Família, outras formas de atenção são disponibilizadas, como orientações dos agentes de saúde, consultas, orientações e cuidados de enfermagem. Essa forma de atenção parece responder a muitas demandas das gestantes, o que permite julgarem que podem prescindir das consulta médicas.

Uma queixa feita por cerca de $20 \%$ das adolescentes refere-se ao fato de que preferiam fazer o pré-natal com o médico que fosse realizar o parto. Por isso, muitas deixam de fazer o pré-natal nas unidades de saúde da família e recorrem aos Centros de Saúde.

O tipo de parto realizado na primeira gestação foi normal/natural para $75,5 \%$. Na segunda gestação, todas haviam realizado partos do tipo normal/natural e entre aquelas que ainda estavam gestantes, 79,1\% esperavam fazer esse tipo de parto. Da mesma maneira, as adolescentes que já tinham o terceiro filho, todas fizeram parto do tipo normal/natural. Apesar dos bons indicadores, a cultura obstétrica local, indiscriminadamente, realiza epsiotomias e só não faz mais partos cesáreos, por causa das limitações impostas pelo SUS.

\subsection{5 - Origem das Adolescentes}

Tendo em vista a diversidade dos fluxos migratórios da população regional, investigou-se de qual unidade federativa do país se originavam os familiares das adolescentes e elas próprias. A Tabela 19 apresenta essas informações. 
Tabela 19 - Estado de origem dos familiares e das adolescentes com maternidades sucessivas em Rondonópolis-MT, 2007.

\begin{tabular}{|c|c|c|c|}
\hline Estados & Pais & Mães & Adolescentes \\
\hline MT & 32,6 & 34,7 & 73,3 \\
\hline MS & - & 4,1 & 6,1 \\
\hline$\overline{\mathrm{GO}}$ & 2,1 & 6,1 & 4,1 \\
\hline$\overline{\mathrm{BA}}$ & 16,3 & 18,4 & 4,1 \\
\hline $\mathrm{AL}$ & 6,1 & 6,1 & 6,1 \\
\hline $\mathrm{PE}$ & - & 2,1 & - \\
\hline$\overline{\mathrm{MG}}$ & 6,1 & 6,1 & - \\
\hline SP & 8,2 & 4,1 & 2,1 \\
\hline$\overline{\mathrm{PA}}$ & 2,1 & - & - \\
\hline$\overline{\mathrm{AC}}$ & 2,1 & 2,1 & 2,1 \\
\hline$\overline{\mathrm{RS}}$ & 2,1 & - & - \\
\hline $\mathrm{PR}$ & 6,1 & 8,1 & - \\
\hline Não soube informar & 14,3 & 8,1 & 2,1 \\
\hline Outro país (Bolívia) & 2,1 & - & - \\
\hline Total & $\overline{100}$ & 100 & 100 \\
\hline
\end{tabular}

Os familiares migrantes vieram, predominantemente, dos estados da Bahia, Alagoas, São Paulo, Paraná e Minas Gerais. Entretanto, as informações demonstraram que houve deslocamentos populacionais também dentro do próprio Estado do Mato Grosso. Entre as adolescentes que declaram ser naturais do Estado, 44,9\% não nasceu no município de Rondonópolis.

Entre suas mães, naturais do Mato Grosso, 77,6\% nasceram em outros municípios do Estado. Também entre seus pais, nascidos no Mato Grosso, 77,6\% nasceram fora de Rondonópolis. Essa informação corrobora o caráter nômade de muitos grupos familiares que vieram para as regiões de fronteira, que pareceu, foram guiados pelas expectativas de riqueza e oportunidades de trabalho.

Quanto à cor da pele, $49 \%$ das adolescentes declararam-se de cor parda, $32,6 \%$ de cor negra e, $18,4 \%$ de cor branca. 


\subsection{6 - Relação com Pai e Mãe}

Nas entrevistas com as adolescentes observou-se um grande 'desprendimento em relação às suas origens'. Houve casos que não sabiam dizêlas minimamente, consultavam outros familiares da casa para responder. A respeito do pai, 14,3\% não sabiam dizer, por exemplo, de qual Estado ele era natural. Em parte, o desconhecimento se explica porque algumas não o conheceram e muitas porque não o conheceram a tal ponto. A Tabela 20 apresenta os tipos de vínculo entre os seus progenitores.

Tabela 20 - Vínculo entre os progenitores das adolescentes com maternidades sucessivas em Rondonópolis-MT, 2007.

\begin{tabular}{lcc}
\hline Tipos & $\mathbf{N}$ & $\mathbf{\%}$ \\
\hline Pais em união estável, criada pelos pais. & 13 & 27,1 \\
\hline Pais separados, criada apenas pela mãe. & 18 & 37,5 \\
\hline Pai e mãe nunca formaram uma parceria, criada apenas pela mãe. & 2 & 4,1 \\
\hline Criada por terceiros (parentes e/ou família adotiva). & 15 & 31,3 \\
\hline Total & $\mathbf{4 9}$ & $\mathbf{1 0 0}$ \\
\hline
\end{tabular}

As informações permitiram concluir que $72,9 \%$ das adolescentes entraram na adolescência sem a presença paterna. Nesse sentido, chama a atenção que, 41,6\% das adolescentes foram criadas apenas pela mãe (pelo menos em um período da vida) e que, $31,3 \%$ foram criadas por outras pessoas que não os pais biológicos.

Essas condições parecem perpetuar para muitos de seus filhos, pois $38,7 \%$ delas tinham filhos com mais de um parceiro. Foi observado que por causa, geralmente, do novo parceiro ou da nova gravidez, algumas deixam o filho "mais velho" aos cuidados de algum parente (mãe, tia, ex-sogra). Contudo, não foi encontrada nenhuma que tivesse doado ou perdido a guarda de algum filho.

As representações que as adolescentes tinham do pai variaram de indiferente a negativa em 60,5\% dos casos. Quando estimuladas a falarem do pai, uma porção de impropérios lhe era dirigido, principalmente, àqueles pais que elas julgavam ter lhes negado a paternidade, quer seja, não as assumindo, abandonando a mãe, sendo violentos, usando drogas, entre outros acontecimentos. Apenas 39,5\% tinham representações positivas dos pais. 
Aquelas que tinham uma representação negativa e/ou indiferente do pai, muitas vezes, referiram-se a ele com certo desprezo e agressividade, pareceram acusá-lo de não cumprir o "papel de pai e de marido". O uso do advérbio "nunca" por várias adolescentes parece expressar a magnitude desses sentimentos e traz consigo, a sensação de que jamais, em tempo algum, tiveram algum benefício paterno.

A esse respeito, Aline falou: "não sei nada sobre ele, nunca conheci, uns falam que era ruim, que bebia muito, outros, que era bom”. Emocionada, Lara contou: "não tenho contato, só por telefone, só manda pensão prá mim, nunca tive o contato de pai e filha, nunca tive carinho, ele nunca viu as netas".

Ainda sobre o pai, surgem "estórias dramáticas". Geórgia disse: "não conheço ele, já morreu, minha mãe nunca fala nele, nunca ouvi falá dele, quando minha mãe tava grávida de mim de três meses, a mulher dele tava de oito meses". Bárbara comentou: "meu pai nunca ajudou, não sou muito chegada nele não, a gente sabe que pai é tudo, mas o que ele fez, ele já matou, ficou preso, ameaçava minha mãe, é melhor ficá longe. Na escola, no dia dos pais eu dava a lembrança prá minha mãe, ela era pai e mãe”.

Márcia, por sua vez, desabafou: “meu pai é um irresponsável, não vejo ele como um pai, mas como um conhecido, ele é um drogado, já dei parte dele, ele me bateu, ele ficou preso dois meses, apesar de eu gostá dele, sinto raiva dele, do que ele faz. Quando ele usa droga, ele tenta matá a minha avó, isso aconteceu várias vezes, ele não cumpre o papel de pai, nunca cumpriu o papel de marido, por isso minha mãe se separou dele, ele tinha amantes, filhos com outras, nunca deu nada para estes filhos, só bate”.

Também Judite fez um desabafo: "prá mim ele não significa um pai, minha mãe que me criou sozinha, ele não ajudou em casa, só ela que trabalhava, desde nova eu dormia com minha mãe por que ela desinteressou dele, ele nunca me deu carinho, ele passa aqui, eu dô bença, mas é só por dó, não sinto nada por ele".

Em oposição às representações trazidas pelo "nunca" estão aquelas delineadas pelo uso do advérbio "sempre", o que pareceu, queriam assinalar a intensidade e firmeza da presença paterna em suas vidas ou em partes dela. Luiza 
comentou: "meu pai sempre esteve presente na minha infância, atualmente, me vê pouco, mas relacionamos bem”. Mariane foi cautelosa: "não tenho nada pra falá dele não, ele sempre ajudou... ele foi embora faz três anos”. Silvana, por sua vez, disse: "não tenho convivência com ele, muito difícil ele vir me visitá, mas me liga sempre, sinto que ele é carinhoso".

Entretanto, se essas falas revelaram a intensidade da "presença paterna" para essas adolescentes, ao mesmo tempo parecem denunciar que ela não subsistiu no tempo, ou seja, a relação com o pai foi intensa, mas ele se afastou ou foi embora.

Certo cuidado com o pai (biológico) apareceu na fala de algumas adolescentes que são filhas adotivas, ao mesmo tempo em que acentuavam as 'características do pai adotivo'. Denise esclareceu: “meu pai é uma pessoa boa, sempre esteve presente, assumiu a gente, mas é imaturo, tem estudo, mas não pára em trabalho nenhum, é uma pessoa ótima... agora o meu pai biológico, minha mãe falô que mora na vila”.

Jocilene se empolgou ao falar dos pais: "o meu pai biológico eu não conheço, minha mãe fala que ele mora por aqui... o adotivo, ele é maravilhoso, bom até demais, além de ser pai é meu amigo, tudo que eu preciso ele faz, conversa, explica, tenta ajudá... acho que ele deveria por uns limites, mas ele é tão bom que não consegue”. Lea por sua vez, disse: “meu pai é um amor de pessoa, meu pai memo mora no Rio de Janeiro ... o que me criou desde seis meses também é um amor, cuidou de mim, os dois são bom”.

Para Vanessa, o pai adotivo parece ter resolvido um enigma: "conheci meu pai verdadeiro quando tinha 16 anos, o meu pai é meu tio, irmão de meu avô, ele é tio da minha mãe... eu considero meu padrasto meu pai”.

Houve também algumas referências ao pai que parecem ser pautadas por uma dimensão temporal, ocasião em que 'algo radical ocorreu'. Daniele contou: "ele me deixou quando eu tinha um ano, de vez em quando vejo ele, mas só de vez em quando”. Fernanda lamentou: "meu pai morreu quando eu tava com dois anos".

Mayara, por sua vez, disse: "não tenho nada prá contar dele não, minha mãe que abandonou ele quando eu tinha um ano, falo com ele mas não 
conheço ele, já passei semanas com ele mas não conheço ele, entende, é como um estranho ... ele é meu pai, mas toda vez que precisei dele, ele não quis ajudar". Já Leocádia, se emocionou ao contar do pai: "só lembro da feição dele, ele era bom, espero que ele volte, fico esperando ele voltá, desde os sete anos que não vejo, eu jogo que ele está na Bahia com os amigos, dá uma saudade”.

Luiza contou o quê ficou sabendo do pai: "não conheci meu pai, quando ele morreu eu tinha um ano e pouco, fui criada com minha avó, falam muita coisa dele, que era mulherengo, danado, cachaceiro... dizem que ele tinha muito ciúme de eu, só tinha eu”.

Arícia lamentou pelo pai que teve: "meu pai é ruim, era um bandido, lembro que nos dias dos pais a cadeira estava sempre vazia, até os 14 anos não sabia nada do pai, quando conheci era uma imagem diferente da que sonhava".

Algumas adolescentes falaram de como o 'pai se transformou', transformando a relação entre eles: Cíntia contou: "ele nunca ajudou em nada, não tenho nada prá falá dele, um dia ele quis batê na minha mãe, dai ela largou dele, agora ele tá se reaproximando, parô de bebê já faz três anos. Fátima disse: "ele é legal, bom, e depois da primeira neta melhorou muito, antes era muito bruto, rude, agora brinca comigo".

Laíze riu do jeito do pai: "ele ficou louco da vida por que virou avô muito cedo, depois ele ficou vaidoso, me ajudou e ajuda em tudo que preciso". Luciane, por sua vez, contou: "ele era muito rígido, ele me prendeu muito, eu sou chateada com ele, sai de casa com 14 anos prá morá com meu esposo, meu pai deu queixa na polícia por que fugi, fiquei muito chateada, mas hoje está tudo bem.

Rose, por sua vez, contou: meu pai fazia coisas erradas, roubava, foi preso, falava que ia mudá, mas não mudava, ai minha mãe largou dele, graças a deus ele parou com isso, depois que engravidei não fui mais lá... ele não viu a gente crescê, ficá moça, tem momentos que fico com raiva dele, mas quem sou eu para julgá”.

O 'abuso de drogas', lícitas e ilícitas, pelos pais é uma outra referência presente na fala de várias adolescentes. Daniela contou de seu pai: não sei muita coisa dele, ele tem os problemas dele de coração, de bebida, fica bêbado, mas 
vou morar com ele, ele me deu mais apoio. O pai de Nures não sobreviveu ao alcoolismo: "não cheguei a conhecê, quando fui conhecê, ele já tinha falecido, não acredito no que contam dele, só sei que ele bebia bastante, ele morava com um travesti, depois foi morá num abrigo antes de morrê"”.

Raquel ficou emocionada ao contar do pai: “meu pai é afastado, não tenho atenção dele, só quando era pequena e minha mãe pedia coisas para ele e ele trazia. De vez em quando ele vem aqui e dô bença prá ele, é a única coisa, depois que tive a vida de casada, ele se afastou, mas foi ele que deu tudo do casamento, ficou triste de eu me separá e, ainda, fiquei aqui com muito má companhia e ele não gostou... antes de eu me torná mulher, ele queria que eu estudasse, tivesse uma profissão. Ele bebia, me batia quando estava bêbado".

Priscila, por sua vez disse: "ele não conviveu comigo, por que ele é alcoólatra, bebe e saí pelo mundo, desde que eu era criança que ele é assim, mistura bebida com droga... apesar de tudo foi ele que educou a gente”. Jéssica acrescentou: "ele bebia demais, ficava o dia todo na farra e não ajudava a mãe, eu gosto dele, mas não vejo mais ele, sinto saudades".

Aparentemente, esses depoimentos invertem a lógica do senso comum de que são os filhos que usam drogas. Aliás, apenas 4,1\% das participantes referiram que faziam uso de drogas (crack) antes da gravidez, mas pararam, justamente, por causa da maternidade.

Aparentemente associado ao abuso de drogas dos pais, as situações de ‘violência e mortes violentas' são relativamente comuns nos relatos: Gláucia diz: "ele tentou matar a gente, mandou um tio batê na minha mãe, tentou se matá, falava que minha mãe estava na zona". Joelma lamentou: "ele é bem diferente da minha mãe, é mais carinhoso, mas é dificil, ele bate na gente”. Arícia explicou: "ele morreu assassinado a facadas". Luiza também explicou: "ele morreu de facada por causa de mulher numa briga”. Geórgia contou indiferente: "mataram ele enforcado".

De maneira geral, o cenário das representações sobre o pai foi caracterizado muito mais por desencontros e contradições, do que por regularidades. Entretanto, o caráter dramático pareceu permear de ponta a ponta 
as vivências das adolescentes, mesmo quando as relações eram de reciprocidade entre pai e filha.

A representação da mãe parece assumir contornos menos dramáticos, mas nem por isso, menos conflituosos. Predominam as referências positivas à mãe nas falas de $66,7 \%$ das adolescentes. Outras $18,7 \%$ posicionaram-se de forma indiferente à mãe e 14,6\%, negativamente.

O que, inicialmente, se apresenta é a tradicional concepção de que "mãe é sempre boa", conforme disse Patrícia. Para Fabrícia, "ela é tudo, nos bons momentos e ruins, ela está perto sempre que preciso, vejo ela todo dia”. De certa forma, as falas serpenteiam em torno desse eixo, até porque esse parece ser o ideal de mãe que tentam seguir. Como disse Aline, "ela é a lei da casa, tenho carinho e respeito".

Outro qualificativo às mães é dado pela noção de 'mulher guerreira'. Priscila disse: "ela é uma guerreira, já sofreu e venceu na vida, morava na Bahia, deixou tudo lá, sofre com meu pai há mais de trinta anos, mas continua firme”. Judite contou: "não sou muito apegada a ela, mas ela que sempre deu de tudo, ela que me deu atenção, sozinha, ela foi minha mãe e meu pai, hoje eu vejo que fiz ela sofrê, tinha que i me buscá na rua”.

A fala de Judite traz à baila outro aspecto, o 'estado solitário' e com elevado número de filhos, com que essas mulheres, geralmente desempenharam a tarefa materna. A Tabela 21 apresenta as informações a respeito do número de FNV das mães das adolescentes. Chama a atenção que apenas 26,5\% dessas mulheres tiveram menos de três filhos.

Tabela 21 - Número de FNV de mães das adolescentes com maternidades sucessivas em Rondonópolis-MT, 2007.

\begin{tabular}{lcc}
\hline Filhos Nascidos Vivos & $\mathbf{N}$ & $\mathbf{\%}$ \\
\hline 1 a 2 & 13 & 26,5 \\
\hline 3 a 4 & 15 & 30,7 \\
\hline 5 a 6 & 13 & 26,5 \\
\hline 7 ou mais & 6 & 12,2 \\
\hline Não soube informar & 2 & 4,1 \\
\hline Total & $\mathbf{4 9}$ & $\mathbf{1 0 0}$ \\
\hline
\end{tabular}


Leocádia, a respeito da 'luta pela vida' que sua mãe protagonizou, explicou: "minha mãe criou nós sozinha mesmo, ela é boa, trabalhou o tempo todo em firma pra criá a gente e ainda ajuda até hoje, ainda bem que ela não deixou faltá nada”. Denise acentuou: "ela é tudo pra mim, apesar de sempre dar puxão de orelha para cuidá da gente, meu pai nunca deu pensão”. Aliás, a luta pela vida, parece ter privado Rafaela de ter maior contato com a mãe. Disse ela: "ela sempre se preocupou, sempre trabalhou, dificil dela estar presente em casa, eu aprendi mais com as pessoas, ela não é de demonstrá amor".

O afastamento da mãe e mesmo a 'ausência da mãe' é outro aspecto, que nas falas, surgem como denúncias, ou seja, parecem que foram registradas como omissão ou rejeição. Daieni disse: "não converso muito com ela, ela me mandava embora de casa por causa do meu padrasto”. Denise comentou: "minha mãe ficou revoltada depois da morte do meu pai, não quis mais cuidá da gente”. Márcia, por sua vez, lamentou: “acho que minha mãe nunca esteve muito presente".

$\mathrm{Na}$ ausência da mãe, muitas adolescentes foram criadas pelas avós: Silvana contou: "fui criada pela minha avó, desde que minha mãe se separou ela voltô a morá com minha avó e quando ela arrumô o meu padrasto, fiquei morano com a minha vó, a infância inteira passei morano com a avó”. A mesma estória aconteceu com Fabiana. Disse ela: "sou criada pela minha vó, minha mãe arrumô outro marido e foi embora, eu tinha seis meses, desde então, minha avó e meu avôdrastro que me criaram".

Para Arícia, o contato com a mãe foi ainda menor. Disse ela: "não tive muito contato, raramente ela ia me visitá, com oito anos que ela veio no sítio me visitá pela primeira vez. Ela não casô, vive sozinha, ia pouco visitá, foi minha vó que me criou, ela foi mãe e pai ao mesmo tempo”. Também Sílvia foi criada pela avó. Ela explicou: "minha mãe tem um jeito estranho não é de dá carinho, fui criada mais com minha avó, pois ela era mãe solteira e tinha que trabaiá".

Assim como ocorreu em relação aos pais, o 'uso de drogas pelas mães' aparece como um problema. Mariane disse: “minha mãe é louca, dá muito trabalho, ela bebe muito, fuma pasta base, fico nervosa com ela, mas se não fosse ela, eu já tinha morrido, mesmo ela tendo as dificuldades dela." Jocilene, 
lamentou: "minha mãe biológica era usuária de drogas e álcool... desde os quatro meses de gestação eu já estava doada”.

A mãe não aparece como provocadora de 'situações violentas' e quando a violência foi citada, pareceu ser tomada como algo natural à criação dos filhos. Gláucia comentou: "minha mãe não tem nada ruim, batê toda mãe bate, o que eu acho ruim é que ela fica viajando pelo mundo".

'Viajar o mundo' pareceu ser uma senha que explicou a situação de algumas adolescentes que foram criadas pelas avós ou por famílias adotivas. Nures esclareceu: "eu não fui criada por ela, o tempo inteiro ela viajando, vinha de mês em mês, ela era mulher da vida, fazia programa, mas hoje nos damos até bem, acho que porque ela mora longe, vou na casa dela no final de semana”. O mesmo parece ter ocorrido com a mãe de Maira: "nós não conversamos muito, toda vez que a gente se encontra, nós sempre brigamos, quando está longe dá saudade, quando está perto, sempre brigamos, foi minha avó que me criou”.

Outra dimensão que se apresentou é a que se refere aos conflitos mãefilha. Santina disse: "A gente não dá muito certo, mas também não consigo ficá longe, quando soube que eu estava grávida, tentou fazê eu abortá, ela é nervosa, ignorante e estourada". A contradição apareceu na fala de Fátima também. Disse ela: "ela é legal, mas, às vezes, é muito nervosa estressada, fica nervosa à toa". Também Rose falou de sua ambigüidade em relação à mãe: “com ela não sou uma filha $100 \%$, mas eu não suporto ela, tem hora que vem uma raiva, mas sinto amor por ela, ela é muito boa".

Finalmente, há as falas que revelam uma grande reciprocidade entre mãe e filha. Luzia disse: "ela tem uma relação aberta comigo, ela mora longe, mas sempre conversamos”. Marciane também destaca o quanto conversava com a mãe: "ela é boa, alegre, não sei dizer como, sempre ajudou a gente, conversava muito, muito aberta ao diálogo". Jéssica disse: "ela aconselhava a gente bastante, é bem amiga, ela tem o jeito dela de ser amorosa".

A mãe aparece como a grande acompanhante das adolescentes em suas maternidades, mesmo entre aquelas que estavam em parcerias fixas. Aliás, se a gravidez é um momento que pareceu provocar rompimentos e discórdias entre mães e filhas, o parto e os cuidados de maternagem pareceram servir para que 
ajustassem suas diferenças e iniciassem um período de maior reciprocidade. Nesse sentido, $87,7 \%$ referiram sentirem-se apoiadas pela família (leia-se 'pela mãe') na primeira maternidade e $83,3 \%$ na segunda e terceira maternidade.

Acerca da hipótese de que a gravidez na adolescência pode relacionarse à 'repetição' do padrão reprodutivo adotado pelos familiares antepassados, investigamos a idade com que as mães das adolescentes ficaram grávidas pela primeira vez. A Tabela 22 apresenta essas informações.

O dado mais expressivo obtido é que enquanto $49 \%$ das adolescentes ficaram grávidas antes dos 15 anos, apenas 12,2\% de suas mães assim ficaram, ou seja, com essas participantes, a história se repetiu para poucas. Entretanto, não se pode afirmar o mesmo, quando analisamos se suas mães ficaram grávidas antes dos 20 anos.

Tabela 22: Idade da primeira gravidez da mãe das adolescentes com maternidades sucessivas em Rondonópolis-MT, 2007.

\begin{tabular}{lcc}
\hline Faixa Etária & $\mathbf{N}$ & $\mathbf{\%}$ \\
\hline Menos de 15 & 6 & 12,2 \\
\hline 15 a 16 & 13 & 26,5 \\
\hline 17 a 18 & 10 & 20,4 \\
\hline 19 a 20 & 6 & 12,2 \\
\hline Acima de 21 & 5 & 10,2 \\
\hline Não soube informar & 9 & 18,5 \\
\hline Total & $\mathbf{4 9}$ & $\mathbf{1 0 0}$ \\
\hline
\end{tabular}

Investigamos, também, sobre situações de ocorrência de violência doméstica. Referiram ter sido vítimas de algum tipo de violência, 38,8\% das adolescentes. Dessas, 68,4\% disseram ter sofrido violência física, 15,8\%, violência sexual e outras $15,8 \%$ referiram ter sido vítimas de violência moral. Contudo, apenas $10,5 \%$ referiram ter denunciado. 


\section{3 - CONTEXTO DE INICIAÇÃO SEXUAL E REPRODUTIVA}

Ela passou do meu lado/ Oi, amor - eu lhe falei Você está tão sozinha/ Ela então sorriu pra mim

Foi assim que a conheci

Hoje a noite não tem luar - Legião Urbana

\subsection{1 - A Menarca}

A faixa etária com maior percentual $(36,8 \%)$ de ocorrência da menarca entre as adolescentes abrangeu o período compreendido dos 12 anos aos 12 anos e 11 meses. A Tabela 23 apresenta as ocorrências da menarca conforme as faixas etárias das participantes.

Tabela 23 - Idade da menarca conforme faixa etária das adolescentes com maternidades sucessivas em Rondonópolis-MT, 2007.

\begin{tabular}{lcc}
\hline Faixa Etária & N & $\mathbf{\%}$ \\
\hline Menos de 11 anos & 5 & 10,2 \\
\hline De 11anos a 11/11 & 16 & 32,6 \\
\hline De 12 a $12 / 11$ & 18 & 36,8 \\
\hline De 13 a 13/11 & 05 & 10,2 \\
\hline 14 e acima & 05 & 10,2 \\
\hline Total & $\mathbf{4 9}$ & $\mathbf{1 0 0}$ \\
\hline
\end{tabular}

Embora a menarca seja um importante marcador biológico da puberdade, é no âmbito das vivências da adolescência que ela parece ganhar contornos mais nítidos. A fala de Márcia revelou bem toda a dimensão conflitiva que lhe foi apresentada com a menarca: "eu já sabia que ia acontecê, achei normal, mas chorei porque minha mãe falou que eu tinha virado moça e eu queria continuá criança”.

Chamou a atenção, as referências feitas por $69,2 \%$ das adolescentes quanto ao papel desempenhado pela própria mãe na 'preparação para a menarca', no auxílio dado quando de sua chegada e apoio oferecido posteriormente. 
Luciane disse: "sabia pouco sobre a menstruação, sabia que ia acontecê, mas não sabia como, não quis contá prá minha mãe, depois minha mãe descobriu e me ajudou”. Bárbara revelou sua surpresa: “minha mãe sempre falava, mas fiquei assustada". Daniele relembrou: "minha mãe me explicava como era, me dava assistência, ela que sempre explicava as coisas". Fabiana, por sua vez, disse: "eu não sabia nada, minha mãe que falou que era normal". Leocádia enalteceu o zelo da mãe: "minha mãe já tinha explicado sobre menstruação prá nós, ela falava que era prá falá quando vinse, aí ela ia acompanhando, não deixava lavá a cabeça de noite, cuidava muito prá nós não ter cólica”.

Até mesmo aquelas que não se sentiam amparadas pela mãe parecem responsabilizá-la. Fernanda lamentou a desconfiança da mãe: "não sabia, minha mãe nunca falou desses negócio, tanto que quando veio, minha mãe achou que eu tinha me perdido". Daiane disse como descobriu observando a sua mãe: "eu não sabia nada, minha mãe não falava, mas eu era curiosa e ficava olhando ela e via ela usando absorvente. Jocilene contou que não teve mãe para ensiná-la: "minha cunhada que me ensinou pelo fato de minha mãe ter me abandonado".

As irmãs, avós e amigas surgem também como pessoas com as quais puderam contar: "minhas irmãs que me ensinaram", disse Mayara. Rafaela contou como ficou sabendo da menstruação por meio das amigas: "eu fiquei assustada porque não sabia o que era aquilo, minhas amigas que explicaram depois". Maira, por sua vez, contou com ajuda da avó: "não sabia nada, fiquei assustada, depois que minha avó falou o que era".

A escola, que, aparentemente, tem uma considerável importância na formação sobre a menarca/menstruação, aparece pouco nas falas das adolescentes quando comparada ao papel da mãe. Maria disse: "sabia quase tudo, ensinavam tudo na escola, fiquei normal quando veio”. Gesane comentou: "eu já sabia, tinha aprendido na escola". Lea relembrou seu "não saber": "eu não sabia nada, quando veio, eu gritei, minha mãe veio correndo, ninguém tinha falado nada não, nem na escola cheguei a saber, sabia que a mulher menstruava, mas não sabia como era". 
Aliás, a escola surgiu como um ambiente que não conseguiu acolher a chegada da menarca. Fátima disse: "foi um susto, foi na escola, fiquei assustada, pedi pra ir embora”. Denise contou que ficou com vergonha: "minha mãe já tinha falado, mas achei estranho, ainda foi em público na escola”. Nures falou de seu desespero: "eu tava na escola, senti uma cólica, achei que ia morrê, minha mãe falava prá mim por absorvente, mas eu não queria por, achava que tava morrendo".

Essas falas das adolescentes mostram-se contraditórias aos dados obtidos quando lhes foi perguntado qual foi a principal fonte de informações sobre sexo e sexualidade. Conforme apresenta Tabela 24, a escola é apontada por 32,7\% das adolescentes como o principal lugar de aprendizado sobre sexo e sexualidade, enquanto que a mãe, por apenas $12,2 \%$.

Tabela 24 - Acesso a informações sobre sexo e sexualidade entre adolescentes com maternidades sucessivas em Rondonópolis-MT, 2007.

\begin{tabular}{lcc}
\hline Fontes & $\mathbf{N}$ & $\mathbf{\%}$ \\
\hline Escola & 16 & 32,7 \\
\hline Mãe & 6 & 12,2 \\
\hline Sozinha & 7 & 14,3 \\
\hline Amigo/Colega & 9 & 18,4 \\
\hline Outros familiares (irmã/tia/avó) & 3 & 6,1 \\
\hline Escola + Familiares & 3 & 6,1 \\
\hline Televisão & 2 & 4,1 \\
\hline Namorado & 2 & 4,1 \\
\hline Pai & 1 & 2 \\
\hline Total & $\mathbf{4 9}$ & $\mathbf{1 0 0}$ \\
\hline
\end{tabular}

Desencontros que se explicitam pela observação de que mãe acolhe e a escola, escolhe, ou seja, talvez a mãe consiga dar uma continência ou a ela lhe é atribuído esse papel, atribuição que a escola nem sempre consegue desempenhar. Há também que se pensar, que, culturalmente, as coisas íntimas pertencem à esfera doméstica, 'roupa suja se lava em casa' e não na escola.

As sensações de pânico parecem ter acompanhado a menarca de várias adolescentes. Aline disse: "não sabia o que era, achei que tinha machucado, minha mãe que falou o que era". Anaclara confessou: "fiquei desesperada, 
ninguém explicou nada, fiquei com medo". Luiza contou seu desespero: "não sabia nada não, fiquei assustada, não queria contá prá ninguém, depois que eu vi aquele trem saindo demais, resolvi contá prá minha avó, ela falou que era normal" Arícia achou que morreria: "eu quase morri”. Fabrícia achou que tinha adoecido: "minha mãe tinha explicado como era, mas assustei bastante, pensei porque eu era assim, achei que era doente".

Também as sensações de vergonha as acompanharam. Gláucia revelou: "minha mãe falava que ia vir, mas quando veio fiquei com vergonha". Também Fabiana contou o que sentiu: "não sabia o que era, fiquei com raiva, meu tio ficou tirando sarro, depois fui entendendo o que era”. Judite comentou: "fiquei com vergonha de meu cunhado".

Mas menstruar, 'virar moça' é outro universo que se descortina e é nas recomendações de muitas mães e outros convivas que a menarca é relacionada à reprodução/sexualidade, parecendo acentuar que com a menarca uma nova responsabilidade para com corpo se apresentava.

Raquel contou como julgava que ela era e as recomendações que recebeu da mãe: “eu não sabia nada, era meio boba, fiquei com vergonha, minha mãe falou que eu era moça e não podia deitá com home não, mas eu não sabia o que era isso". Priscila disse: "eu fiquei assustada, minha mãe que foi explicando, depois falô que eu tinha virado moça”.

A mãe de Sara destacou a nova condição: "minha mãe me explicava o que ia acontecê, me falô que eu tava virando moça”. Também a mãe de Silvana fez recomendações: "eu sabia por que minha mãe falava que eu não podia brincá mais com menino home, que eu tinha virado moça”. Judite, por sua vez, disse: "eu não sabia nada, morava com minha irmã e saí correndo para a casa da outra irmã, ela que me explicou e que já corria risco".

Mas se a chegada da menstruação traz os conflitos entre 'continuar criança' e 'virar moça', para algumas, a menarca era muito desejada. Disse Rose: "fiquei um pouco nervosa, eu queria virá mocinha, mentia para a minha mãe que já tinha vindo, ela ia olhá e não era nada”.

Temos, portanto, que a nova condição que se instaura com a menarca é muito mais que o fato revelado em seu determinismo biológico. Ela aponta 
também para as dimensões subjetivas que norteiam as práticas sexuais e a construção da identidade. Nesse ínterim, o vislumbre da maternidade parece aproximar-se muito rapidamente.

\subsection{2 - A Iniciação Sexual e a Primeira Maternidade}

Se por um lado a menarca aponta para novas dimensões da vida da adolescente, notadamente para a maternidade, por outro, a iniciação sexual parece consolidá-las e afirmar-se enquanto ritual de passagem com grande significação. Entretanto, é de estranhar que a expressão muito comum usada por várias adolescentes para se referirem ao ato da própria iniciação sexual seja "eu me perdi".

A expressão parece condensar uma porção de elementos e valores culturais acerca da iniciação sexual. Claramente influenciada pela concepção cristã de sexualidade, 'perder' traz, inicialmente, a conotação de prejuízo, passar de um estado a outro pior.

A iniciação sexual na cultura cristã sempre foi rechaçada em nome da castidade - condição moral - e da virgindade - condição biológica - e associada à pureza, que pressupõe, é própria das crianças e as aproxima de deus. 'Perder-se', é então, sair do caminho, desvirtuar-se, perder a virtude da pureza. 'Perder-se' aqui é substantivo.

Ou seja, a primeira noção cultural que se apresenta à iniciação sexual tem um tom depreciativo, trata-se de uma desobediência a certa lógica em que se assentam as construções culturais que pretendem nortear a sexualidade e suas práticas. Talvez por isso, 24,5\% das adolescentes tenham, no início da gestação, escondido e/ou disfarçado a gravidez, já que para muitas, a primeira gravidez coincidiu com a iniciação.

Nures contou como "se perdeu" e as conseqüências do ato. Disse ela: “depois que me perdi, fiquei preocupada e nervosa da minha mãe me batê, foi o que aconteceu, me bateu muito, mandou embora de casa, fui para casa da minha 
tia, minha mãe jogou minha roupa na rua, ela só me aceitou quando caiu, eu perdi o nenê".

O que se observa na fala de Nures e de várias outras adolescentes é que a concepção religiosa tem considerável influência, por mais que no senso comum, se avalie ou se diga que esses valores deixaram de existir. Aliás, é muito corriqueiro associar a gravidez na adolescência à "promiscuidade sexual", o que sugere também, a existência de muitos parceiros sexuais, hipótese não corroborada por estes resultados.

Aliás, eles revelam que em apenas $8,2 \%$ dos casos, a iniciação ocorreu em situações de parceria sexual eventual, em que o parceiro era recém-conhecido. Nas demais situações, $91,8 \%$, havia algum tipo de vínculo que tornava o parceiro familiar, geralmente, namorado (63,3\%). A Tabela 25 apresenta a forma de relacionamento mantido com o parceiro na iniciação sexual.

Tabela 25 - Vinculo mantido com o parceiro na iniciação sexual por adolescentes com maternidades sucessivas em Rondonópolis-MT, 2007.

\begin{tabular}{lcc}
\hline Tipo de vínculo & $\mathbf{N}$ & $\mathbf{\%}$ \\
\hline Namoro & 3 & 63,3 \\
\hline Casamento & 8 & 16,3 \\
\hline Amizade & 4 & 10,2 \\
\hline Recém-conhecido & 4 & 8,2 \\
\hline Outro (primo) & 1 & 2 \\
\hline Total & $\mathbf{4 9}$ & $\mathbf{1 0 0}$ \\
\hline
\end{tabular}

Outra noção que acompanha o "perder-se" parece relacionar-se à idéia de descoberta. Anaclara disse "fui descobri o que era isso com meu namorado, eu me perdi com meu namorado”. Luzia falou: “quando me perdi não sabia muito bem o que estava acontecendo, fui descobrindo com o tempo”. Cíntia comentou: "foi tranqüilo, eu queria." Luiza, por sua vez, disse: “eu quis, foi com meu ficante".

A expressão "me perdi" parece flexionar, denota a ação e a intencionalidade daquela que se perdeu. Virou verbo intransitivo. O "perder-se" ganha o sentido de 'encontrar-se', encontro do próprio corpo com o corpo do outro, encontro de sentidos e de identidades (ser mulher, ser mãe). Mayara disse 
"eu namorava escondido, depois fugi e me perdi". Ou seja, encontrou-se com o seu desejo, conforme contou Priscila: "foi espontâneo, foi bom, maravilhoso".

Prática antiga na cultura brasileira, 'fugir, se perder e casar' ainda subsiste como pano de fundo de algumas iniciações. Para algumas, a fuga seguiu o ritual clássico. A esse respeito, Leocádia confessou que "foi tudo combinado, conversado”. Mas há variantes do ritual. Daieni explicou: “depois que me perdi, nós fugimo pro grilo”. Maira, por sua vez, explicou: "eu passava muita raiva com minha mãe, ela pegava muito no meu pé, ai saí de casa, eu e uma companhia, aí que me perdi”.

Uma preocupação observada em grande parte das mães-adolescentes pautou-se pela afirmação e enaltecimento de que se iniciaram sexualmente com o namorado e após considerável tempo de namoro. Aline contou: "eu me perdi foi com o namorado depois de quatro meses de namoro". Daniela comentou: "foi normal, depois de três meses de namoro”. Fernanda explicou: "quando a gente começou o namoro, começamos a ficá junto, mas foi depois de dois meses de namoro". Denise, por sua vez, contou: "era meu primeiro namorado, eu queria, depois dos sete meses de namoro que fiquei, depois namorei com ele mais um ano e meio".

Outras acentuaram que a iniciação só ocorreu depois do casamento: " $a$ primeira vez foi depois que casei", comentou Danieli. "Foi quando eu casei, antes eu tinha medo", disse Célia.

Contudo, o controle da situação determinante da iniciação sexual parece ter escapulido para muitas e adentrado ao reino da violência que envolve as diferenças entre os gêneros e que colocam, geralmente, a mulher, em desvantagem na relação com o universo masculino. "Foi mais por obrigação, eu era inocente", disse Daieni. Márcia explicou: “acho que eu não queria ter começado, foi necessário, eu nunca gostei de ter relação com ele, eu só descobri o prazer depois dos 16, eu creio que umas crianças que transam não têm prazer, é como se fosse papel de esposa, obrigação”.

Parece tratar-se de um tipo de violência muito sutil, que mescla elementos coercitivos e afetivos: "foi com meu primeiro namorado, ele ficava falando no meu ouvido até que eu aceitei”, confidenciou Lea. Rose explicou mais 
sobre a pressão recebida: "Um pouco foi porque eu quis, mas teve um pouco de pressão, ele falava que não tinha relação com ninguém e eu sentia isso como uma pressão".

$\mathrm{Na}$ iniciação sexual de Joelma, a violência foi escancarada e cometida justamente por quem deveria protegê-la. Diz ela: “foi lá na em Alagoas, um promotor precisava de alguém pra trabaiá e fui trabaiá na casa dele, então, ele só queria me comê, nem me pagô o mês, deixei uma carta e fui embora".

Chama atenção, conforme apresentado na Tabela 26, as informações que, $59,2 \%$ das adolescentes se envolveram com homens com idade consideravelmente maior à que tinham, acima de 20 anos, ou seja, homens, geralmente, com mais vivências e experiências sexuais.

Possivelmente isso colaborou para menor poder de barganha nas tomadas de decisões que cercam a iniciação sexual e, consequentemente, é um indicativo de aumento da vulnerabilidade individual, tanto para que elas sejam vítimas de coerções, quanto para que se exponham à gravidez não quista e às infecções sexualmente transmissíveis.

Tabela 26 - Idade do parceiro na primeira gravidez entre adolescentes com maternidades sucessivas em Rondonópolis-MT, 2007.

\begin{tabular}{lcc}
\hline Faixa etária & $\mathbf{N}$ & $\mathbf{\%}$ \\
\hline $15-19$ & 20 & 40,8 \\
\hline $20-25$ & 19 & 38,8 \\
\hline $26-40$ & 06 & 12,2 \\
\hline 41 e acima & 04 & 8,2 \\
\hline Total & $\mathbf{4 9}$ & $\mathbf{1 0 0}$ \\
\hline
\end{tabular}

A Tabela 27 apresenta a idade das adolescentes quando se iniciaram sexualmente. Embora a média de idade de ocorrência da primeira relação sexual tenha sido de 14 anos, não faltaram falas que assinalaram a idade de 13 anos como referência. Diz Maria: “eu amiguei com 13 anos, com meu marido, ai foi normal, eu queria mesmo, transei um dia depois do meu aniversário”. Mariane conta como foi sua experiência: "foi no dia do meu aniversario de 13 anos, fiquei com medo, começou a sair sangue, fiquei assustada, ao chegá em casa parecia que tava demonstrando prá todo mundo, foi na cachoeira". 
Tabela 27: Idade da primeira relação sexual conforme faixa etária entre adolescentes com maternidades sucessivas em Rondonópolis-MT, 2007.

\begin{tabular}{lcc}
\hline Faixa Etária & $\mathbf{N}$ & $\mathbf{\%}$ \\
\hline Menos de 12 anos & 01 & 2,1 \\
\hline De 12 anos a 12/11 & 09 & 18,4 \\
\hline De 13 a 13/11 & 13 & 26,5 \\
\hline De 14 a 14/11 & 12 & 24,5 \\
\hline De 15 a 15/11 & 11 & 22,5 \\
\hline 16 e acima & 05 & 6,1 \\
\hline Total & $\mathbf{4 9}$ & $\mathbf{1 0 0}$ \\
\hline
\end{tabular}

Outra informação importante para se pensar estratégias de planejamento sexual/familiar com adolescentes é a que se refere ao tempo entre o início da atividade sexual e a primeira gravidez, conforme é apresentado na Tabela 28.

Tabela 28 - Tempo entre o início da vida sexual e a primeira gravidez entre das adolescentes com maternidades sucessivas em Rondonópolis-MT, 2007.

\begin{tabular}{lcc}
\hline Períodos & $\mathbf{N}$ & $\mathbf{\%}$ \\
\hline Menos de 1 mês (na iniciação) & 6 & 12,2 \\
\hline 1 a 3 meses & 4 & 8,2 \\
\hline 4 a 6 meses & 6 & 12,2 \\
\hline 7 a 12 meses & 15 & 30,6 \\
\hline 13 a 18 meses & 4 & 8,2 \\
\hline 19 a 24 meses & 4 & 8,2 \\
\hline 25 a 30 meses & 2 & 4,1 \\
\hline 31 e acima & 8 & 16,3 \\
\hline Total & $\mathbf{4 9}$ & $\mathbf{1 0 0}$ \\
\hline
\end{tabular}

Chama a atenção que $12,2 \%$ das adolescentes referem ter ficado grávida na iniciação sexual. A fala de Bárbara é muito ilustrativa a esse respeito: "me perdi aos 15 anos, foi assim, depois de muitas tentativas dele, eu também queria, tinha medo de doer, mas nem pensava que poderia ficar grávida, pegá barriga, pegá doença”.

No período compreendido de seis a doze meses após a iniciação sexual é que ocorreu o maior percentual de gravidezes entre as adolescentes, 30,6\%. A 
investigação qualitativa dessa informação parece apontar para o relaxamento do uso de contraceptivos nesse período (entre aquelas que usavam). O ‘descuido' parece surgir a partir do momento em que houve um vínculo maior com o parceiro e um sentimento de maior confiança. Curiosamente, nesse sentido, o 'medo da Aids' foi a única justificativa para que algumas permanecessem usando preservativos.

Também merecem destaque a informação que 16,3\% ficaram grávidas trinta ou mais meses após a iniciação sexual. Essa constatação sugeriu que vários aspectos colaboraram para a postergação da gravidez. Entre eles, destacamos o uso correto de contraceptivos, a iniciação sexual seguida pela interrupção da atividade sexual e eventuais dificuldades de fecundação.

\subsection{3 - O Uso de Contraceptivos Antes da Primeira Maternidade \\ O "correr riscos" de Márcia e o "desconhecimento" de Mariane, como} se verá à frente parece constituir o paradoxo com o qual se debatem os trabalhos que visam prevenir situações hostis, agravos à saúde, acidentes, entre outros. No universo estudado, 62\% declararam ter usado preservativos na primeira relação sexual, o que permite supor que tiveram acesso à informação, ao insumo e às condições de uso.

Entretanto, esse dado é muito relativo. A investigação mais aprofundada acerca das declarações dadas pelas adolescentes revelou que muitas informam o que julgam que deveriam ter feito ou que seria a resposta correta. $\mathrm{Na}$ verdade, não o usaram, ou usaram na primeira, mas não nas demais. Há, portanto, um efeito rebote da informação. São capazes de reconhecê-la, mas não de usufruírem dela.

De qualquer forma, há que considerar que o percentual de uso de preservativos numa primeira experiência foi expressivo, não fosse, novamente, um fato curioso. No caso dos contraceptivos, o mínimo percentual de não uso ou uso incorreto/inadequado já é condição suficiente para a ocorrência da gravidez. 
A respeito do uso de métodos contraceptivos antes da primeira gravidez, 53\% afirmaram tê-los usados. Desses, 50\% usou exclusivamente a camisinha, 46,2\% a pílula e 3,8\% anticoncepcional injetável (injeção). Nenhuma referiu o uso de outros tipos de contraceptivos.

Mereceu destaque o considerável aumento do uso da pílula, que na ocasião da primeira relação sexual era usado por apenas $10,2 \%$, o que parece sugerir que a experiência com os insumos protetores aumenta em consonância com a experiência sexual. Na verdade, passa a constituir um paradoxo, pois para muitas não houve tempo de se apropriar dos conhecimentos que as experiências proporcionavam. Ou seja, nessa dimensão da vida, a margem de tolerância é muito estreita.

Entretanto, o uso de contraceptivos aos quais as adolescentes referem devem ser entendidos mais como 'tentativa de uso' do que efetivo uso. Maria confessa: "eu usava uns dias, outros esquecia, noite sim, noite não”. Nures também confessou: “eu esquecia de tomá, tomava semana sim, semana não, dois meses sem pará”. Fernanda, por sua vez, disse: “uma vez eu tentei tomá, mas o remédio fez mal, aí voltei no posto, mas não tinha médico, aí não tomei mais”.

O que se observou é que muitas que fizeram uso de anticonceptivos o fizeram de "forma inadequada". Fabiana diz: "o remédio não fez efeito, foi aí que fiquei grávida”. Anaclara, previdente por seus esquecimentos, contou: “eu usava camisinha e anticoncepcional, porque eu usava o anticoncepcional errado, esquecia de tomá, fiquei grávida porque parei com a camisinha”. Rafaela, por sua vez, falou: "eu estava tomando pílula, mas acho que tomei errado, eu estava tomando e fiquei grávida, ninguém me explicou".

A indicação de que a "pílula fez mal” é uma constante entre aquelas que tentaram usá-la: Diz Mariane: "eu tentava usá, mas passava mal, não dormia direito, acordava zonza”. Cíntia explicou: “eu tomava injeção, mas parei porque o remédio deu enjôo, passei mal. As pessoas podem até não acreditá, mas a camisinha estourou, foi isso que aconteceu”. Luciane, por sua vez, disse: "eu não gostava, o remédio fazia mal". Também Rose comentou sobre o assunto: "parei porque fez mal para o estômago”. 
Há também referências ao uso de “estratégias contraceptivas alternativas e quase mágicas". Daiane contou como fazia: "nunca tomei remédios, usava a tabelinha, mas descontrolou, funcionou por um ano”. Daieni diz: "eu não usava nada porque ele falava que era só transá longe da menstruação”. Lara explicou: "nunca usei remédio nenhum, usei camisinha com muitos, só com meu namorado que não”. Vanessa brincou: “nem preservativo usei, eu até fazia coleção de camisinha, mas não usei”.

Associado a isso, surgiu outra informação, 'o desconhecimento' sobre os métodos contraceptivos. Priscila conta admirada: "eu não sabia desse porém, depois que eu ganhei ele que eu fiquei sabendo de tomá remédio”. Maira é enfática: "eu nunca usei porque eu não conhecia”. Bárbara atribui à sorte sua proteção: "eu tive sorte, porque antes da gravidez eu não usava remédio, essas coisas, num pensava que podia ficá grávida ou pegá doença”.

Jocilene confessou sua ignorância: "não sabia mexer, não sabia como era”. Mayara foi mais esclarecedora: "eu só ouvia falar, não tinha entendimento do que era". Adna também falou: "eu não conhecia”. Essas falas apresentam muito cruamente que muitas adolescentes simplesmente não tinham informações para relacionar o uso do corpo às suas conseqüências, quanto menos protegeremse delas, se assim desejassem.

Portanto, se é verdadeiro que algumas possuem a informação e não conseguem usá-la em benefício próprio, também é correto dizer que muitas nem mesmo tiveram acesso a ela. No caso das participantes, parece que isso está relacionado ao isolamento em que muitas foram criadas, perdidas 'pantanal adentro' ou 'cerrado afora'.

Aliás, também a forma de acesso ao contraceptivo, no caso, isolamento geográfico, parece ter sido determinante para a gravidez de algumas adolescentes. Célia contou: "eu parei depois de um tempo, parei por que acabou o remédio e a gente morava na fazenda e não vinha mais na cidade”.

Essa informação parece ser relevante na medida em que muitas adolescentes moravam na zona rural, em fazendas e assentamentos agrários e vieram para a cidade após a gravidez ou nascimento do filho justamente para tentar garantir acesso a alguns bens públicos. 
Contudo, o acesso aos contraceptivos é barrado também por formas mais sutis e que independem até certo ponto das condições de vida da adolescente. Por exemplo, ainda que a legislação permita o acesso dos adolescentes a consultas médicas sem acompanhantes e aos contraceptivos, é muito comum se observar em unidades de saúde, o estabelecimento de regras que servem muito mais como barreiras de acesso do que tentativas de favorecer e proteger o adolescente.

A exigência de documentação para a prestação de vários serviços, como realização de exames e entrega de preservativos, é outra regra que vulnerabiliza adolescentes e os espantam das unidades de saúde. Jéssica disse: “eu não conhecia e pra pegá a pílula tinha que ser de maior”. Ou seja, nas entrelinhas da fala de Jéssica está dito que, com sua 'cara de menina' encontrou uma porção de barreiras que a impediram de proteger-se. Entretanto, era uma menina com vida sexual!

Algumas, deliberadamente não usaram contraceptivos porque desejavam e planejavam a gravidez: Marciane disse: "parei de tomá pra ficá grávida". Sílvia explicou: "quando fiquei grávida foi porque planejamos e deixamos de usá camisinha”. Lea, por sua vez, disse: “eu parei de usá camisinha porque queria ficá grávida”.

Surge com isso, uma questão paradoxal e que põe em xeque uma porção de 'preventivismos' próprios da sociedade contemporânea e que apregoa o uso disciplinado dos corpos, de suas funções e de seus prazeres. Luiza disse: “eu conhecia o anticoncepcional, camisinha, mas eu não queria usar”. Também, Fabricia, afirmou no mesmo sentido: “eu não quis usar”. Joelma por sua vez, disse: "nem pensava nisso, entrava num ouvido e saía no outro".

Finalmente, a mais enigmática das categorias construídas a partir das informações, referiu-se à 'dimensão irracional' que parece fazer parte do exercício da sexualidade. Gesane disse: "sei lá o que aconteceu na hora, esqueci de usá a camisinha". Claísa contou: "no dia que fiquei grávida eu não quis usá, ele também não, mas a gente não queria tê um filho, tava muito ruim de usá camisinha". 
Raquel, por sua vez, destacou: "ás vezes, na loucura, nós não usava". Santina foi muito além e colocou uma capciosa reflexão acerca dessa dimensão demasiadamente humana. Diz ela: "sempre tem descuido". 


\section{4 - AS MATERNIDADES SUCESSIVAS EM RONDONÓPOLIS-MT}

\subsection{1 - 'Querer e Não Querer' a Primeira Maternidade}

Descobrir-se grávida parece ser uma intrigante experiência feminina e quem sabe, masculina. No caso das adolescentes a descrição de sentimentos ambivalentes pôde ser observada tanto naquelas que desejavam, quanto entre aquelas que não planejavam a gravidez. A Tabela 29 apresenta o tempo referido pelas adolescentes para que se descobrissem grávidas. Há que destacar que 36,7\% levaram mais de três meses para confirmar a gravidez.

Tabela 29 - Mês gestacional de 'descoberta' da gravidez entre adolescentes com maternidades sucessivas em Rondonópolis-MT, 2007.

\begin{tabular}{lll}
\hline Mês de gestação & $\mathbf{N}$ & $\mathbf{\%}$ \\
\hline $1^{\mathrm{o}}$ & 16 & 32,7 \\
\hline $2^{\mathrm{o}}$ & 15 & 30,6 \\
\hline $3^{\mathrm{o}}$ & 08 & 16,3 \\
\hline $4^{\mathrm{o}}$ & 07 & 14,3 \\
\hline $5^{\mathrm{o}}$ e $6^{\mathrm{o}}$ & 03 & 6,1 \\
\hline Total & $\mathbf{4 9}$ & $\mathbf{1 0 0}$ \\
\hline
\end{tabular}

Um considerável percentual das adolescentes, 47\%, disseram que tinham a intenção de "ficá grávida". As informações obtidas revelam que diversos aspectos parecem compor os contextos que motivaram ou colaboraram para a ocorrência da primeira gravidez.

Algumas relacionaram a primeira gravidez à tentativa de 'segurar o homem'. Aline disse: "eu queria, parei de previni porque minha mãe queria empatá meu namoro e eu achava que se engravidasse e fugisse com ele ia segurá alguma coisa". Daieni contou como quem contava um segredo: "queria ficá grávida prá ele ficá junto comigo"

Para outras, a gravidez foi uma forma de 'agradar o marido'. Daniela confessou: “queria, queria um nenê, sei lá, um bebê, mas foi um pouco por causa dele, ele queria um filho também”. Fabiana, mesmo não querendo, submeteu-se e 
o agrado virou obrigação: "queria e não queria, eu pensava não tô afim de ficá grávida, mas todo mundo falava que já fazia tempo que estava casada e que o marido queria um filho... eu falava que ele que se virasse”. Adna também se sentia obrigada: "queria, mas um pouco foi por influência da mãe dele, ele que queria muito, foi depois que eu comecei a aceitá”.

Anaclara, por sua vez, associou a chegada da maternidade a uma 'conquista pessoal', sentia-se, a partir de então, respeitada: “eu queria ser mãe, eu achava que era assim uma responsabilidade, eu fui mais valorizada, ninguém me levava a sério, ninguém acreditava nas coisas que eu falava, gostei de ser mãe”.

Várias adolescentes relacionaram a busca pela gravidez como uma forma de 'evitar a solidão'. Maira diz: “queria prá não ficá sozinha em casa, era chato ficá sozinha, eu quase não saía de casa, ele (o marido) não deixava eu sair de casa com as amigas". Arícia contou: "queria tê um filho prá me fazê companhia, é ruim ficar sozinha”.

Algumas relacionaram a gravidez à 'vontade de ser mãe'. A esse respeito, Sílvia não se conteve: "tinha vontade de ter filho, sou loca pra ser mãe de novo". Já Luiza falou: "queria tanto que nem preocupava com anticoncepcional”. Priscila, por sua vez, estava convicta: "eu queria, não tenho nenhum arrependimento, foi por vontade mesmo". Sara se entusiasmou: "ficá grávida sempre foi minha paixão”. Também Marcilene ficou feliz: “eu quis ficá grávida, fiquei contente, tava ansiosa pra tê um filho".

Mas para outras, embora a vontade estivesse presente, parece que a gravidez estava 'fora dos planos'. Vanessa lamentou: "sempre tive vontade de ficá grávida, mas na época foi por acidente memo”. Desanimada, Denise disse: "eu queria, toda minha vida é com criança, toda vida queria ter o meu filho, eu gosto muito de criança, mas não sonhava em engravidá, era nova, estava estudando".

Aliás, algumas se mostraram preocupadas com a 'nova responsabilidade'. Bárbara avaliou: “eu queria, pensava que tê um filho era muito legal, mas imaginava outra coisa muito diferente, a gente quando é nova acha que ter filho é igual brincá de boneca, mas boneca não come, não chora”. 
O nascimento do filho preocupou Arícia também: "eu fico muito preocupada com a educação dele”. Arrependida, Adna disse: "eu queria, mas não queria, eu sabia que ia prejudicá a escola e várias outras coisas”.

Para outras, a chegada da maternidade pareceu ser o cumprimento de uma sina, a de 'ser mãe'. Gláucia regozijou-se: “queria sê mãe, o meu sonho era sê mãe, sempre gostei de crianças, eu trabalhei de babá, dava vontade de sê mãe, eu reparava as mulher grávida, ficava com vontade”. Léa, por sua vez, disse: "quis ficá grávida, sempre sonhei em ter um filho, eu cuidava do meu sobrinho, eu sonhava alto, ai eu casei, a gente tentou, tentou, mas aí não conseguia, aí, a hora que eu fui vê, tava grávida, fiquei muito feliz".

Também Leocádia ficou entusiasmada: “ficava doidinha prá ele nascê logo, vê como ele era, eu queria sê mãe, sofrê um pouquinho igual a minha mãe sofreu prá tê nós”. De outra forma, para Patrícia, um misto de 'indiferença frente ao destino materno' pareceu tomar conta de si: "sei lá, aconteceu, dava uma vontade de tê um nenê, acho que todas as mulher tem vontade, eu via minhas irmã com os filhos, ficava com vontade".

Para outras participantes, $53 \%$, a primeira gravidez não foi desejada ou planejada e relacionam o 'não querer' a diversos aspectos. Um deles parece referir-se a certo planejamento que pareciam ter para a vida. $\mathrm{O}$ uso das expressões, "muito nova" e "muito cedo", parecem condensar uma mistura de indignação e admiração consigo.

Santina foi enfática: "eu não queria, quer dizer, até queria ficá grávida, mas não naquele momento”. Marciane, por sua vez, relacionou a gravidez com pouca idade às 'obrigações' do casamento: "não queria não, achava muito nova, mas meu esposo queria e eu acabei querendo, mas eu era muito nova". Também Nures lamentou a gravidez em função de sua pouca idade, da ausência de um planejamento e dos conflitos com o parceiro: "eu não queria, eu pensava que tava muito nova, eu não pensava bem, nem o que queria da vida, nós brigava muito".

Fabiana surpreendeu-se com a gravidez 'tão cedo' e tentou conformarse: “não, nunca passô pela minha cabeça a possibilidade de ficá grávida, eu 
queria ser mãe, só que não tão cedo, só que eu tive né”. A idéia de precocidade aparece também na fala de Gesane: "eu não queria não, foi tão cedo”.

Entre as participantes, a média de idade de ocorrência da primeira gravidez se deu aos 15 anos e 2 meses, sendo que 49\% ficaram grávidas antes dos 15 anos e $51 \%$ após, conforme apresentado na Tabela 30.

Tabela 30 - Idade da primeira gravidez conforme faixa etária entre adolescentes com maternidades sucessivas em Rondonópolis-MT, 2007.

\begin{tabular}{lcc}
\hline Faixa Etária & $\mathbf{N}$ & $\mathbf{\%}$ \\
\hline Menos de 13 anos & 01 & 2 \\
\hline De 13 anos a 13 anos e 11 meses & 07 & 14,3 \\
\hline De 14 anos a 14 anos e 11 meses & 16 & 32,7 \\
\hline De 15 anos a 15 anos e 11 meses & 11 & 22,5 \\
\hline De 16 anos a 16 anos e 11 meses & 08 & 16,3 \\
\hline Acima de 17 anos & 6 & 12,2 \\
\hline Total & 49 & 100 \\
\hline
\end{tabular}

Para muitas, o 'não querer' foi motivado por certa noção de que não queriam e 'simplesmente aconteceu'. Claísa comentou: "não queria não, aconteceu". Fernanda tentou se justificar: "não queria, de repente eu fiquei grávida sem nem mesmo esperá que isso ia acontecê, eu fiz muita besteira, não queria tê filho".

O 'não querer' parece revelar também uma sensação de que elas 'foram invadidas', algo a que se submetem à revelia de suas vontades e que parecem reagir com certa agressividade e desdenho.

Laíze se irritou: "não queria de jeito nenhum, só na menopausa, toda desgraça prá pobre é pouco”. Fernanda zombou: “não imaginava grávida nada, eu não me via mãe, eu gosto de filho dos outros, agora meu mesmo”. Joelma, por sua vez, ironizou: “não tinha sonho assim não”. Márcia riu de si mesmo e do método que poderia ter usado para evitar a gravidez: "não queria de jeito nenhum, não foi planejada, foi descuidada, eu sabia da pílula do dia seguinte”.

Foi relacionado ainda à idéia de gravidez como algo que vem de fora, estranho aos quereres da mãe-adolescente, que outros aspectos do "não querer" se revelaram. Geórgia comentou: “eu nem pensava em sê mãe”. Com ares de 
desentendida, Mariane falou: "não tava esperando, foi uma surpresa, minha mãe que falou que a minha menstruação tava atrasada”. Rose, por sua vez, desdenhou: "nem brincá de boneca eu fui chegada”. Judite foi ainda mais enfática: "nunca me imaginava grávida, nunca me imaginei sê mãe, ainda mais do jeito que eu era".

Mas o 'não querer' parece transformar-se pela 'força social da experiência' em 'bem querer'. Para muitas, o início da maternidade se transformou momentaneamente em vantagens que, rapidamente, parecem ser incorporadas como responsabilidades. Algumas contaram como vivenciaram a transição do 'não querer' para o 'bem querer'. Cíntia diz: “eu não queria não, mas depois que engravidei, fiquei toda feliz, antes não me imaginava mãe, não tinha vontade".

Luciane também se mostrou contente com a gravidez após 'não querêla': "quando fiquei grávida eu não queria, era muito nova, não tinha responsabilidade, depois que percebi que era bom”. De outro modo, Mayara pareceu resignar-se: "não pensava em ser mãe, mas depois eu aceitei”.

Outra questão que surge sob a rubrica do 'não querer' refere-se às 'dúvidas e conflitos' comuns entre gestantes. Diz Rafaela: “eu pensava em tê, mas ficava pensando como que ia saí, eu não queria de jeito nenhum”. A preocupação com o corpo apareceu também na fala de Luiza: "não queria não, mas eu imaginava tê uma criança, só ficá gorda que não”. Também no rol de dúvidas e conflitos apareceu a fala de Daiane: "eu queria ter uma menininha, mas pensava e se viesse um menino, minha mãe também falava, fiquei contente de saber que era menina".

Finalmente, talvez a informação que melhor expresse o caráter conflitivo em que esteve envolto a primeira maternidade para essas adolescentes refere-se ao período que dedicaram à amamentação do primeiro filho, conforme apresentado na Tabela 31 . Apenas 47,1\% conseguiram amamentar além dos seis meses. 
Tabela 31: Tempo de amamentação do $1^{\circ}$ FNV em adolescentes com maternidades sucessivas em Rondonópolis-MT, 2007.

\begin{tabular}{|c|c|c|}
\hline Meses & $\mathbf{N}$ & $\%$ \\
\hline Menos de 2 & 05 & 10,2 \\
\hline De 2 a 4 & 14 & 28,6 \\
\hline De 5 a 6 & 07 & 14,3 \\
\hline De 7 a 12 & 10 & 20,4 \\
\hline Acima de 13 & 13 & 26,5 \\
\hline Total & 49 & 100 \\
\hline
\end{tabular}

\subsection{2 - Os Imprevistos da Segunda e Terceira Maternidade}

A média de idade da segunda gravidez foi de 17 anos e 4 meses e da terceira, 18 anos e 2 meses. A Tabela 32 apresenta a idade de ocorrência por faixas etárias.

Tabela 32 - Idade de ocorrência de gravidezes entre as adolescentes com maternidades sucessivas em Rondonópolis-MT, 2007.

\begin{tabular}{lcccc}
\hline & Segunda gravidez & \multicolumn{2}{c}{ Terceira gravidez } \\
\hline Faixa etária & N & \% & N & \% \\
\hline Menos de 15 anos & 1 & 2,1 & - & - \\
\hline De 15 anos a 15 anos e 5 meses & 2 & 4,2 & - & - \\
\hline $\begin{array}{l}\text { De } 15 \text { anos e } 6 \text { meses a } 15 \text { anos e } 11 \\
\text { meses }\end{array}$ & 3 & 6,2 & - & - \\
\hline De 16 anos a 16 anos e 5 meses & 7 & 14,6 & - & - \\
\hline $\begin{array}{l}\text { De } 16 \text { anos e } 6 \text { meses a } 16 \text { anos e } 11 \\
\text { meses }\end{array}$ & 6 & 12,5 & & - \\
\hline De 17 anos a 17 anos e 5 meses & 8 & 16,7 & - \\
\hline $\begin{array}{l}\text { De } 17 \text { anos e } 6 \text { meses a } 17 \text { anos e } 11 \\
\text { meses }\end{array}$ & 5 & 10,4 & & - \\
\hline De 18 anos a 18 anos e 5 meses & 5 & 10,4 & 03 & 33,3 \\
\hline $\begin{array}{l}\text { De } 18 \text { anos e } 6 \text { meses a } 18 \text { anos e } 11 \\
\text { meses }\end{array}$ & 3 & 6,2 & 02 & - \\
\hline De 19 anos a 19 anos e 5 meses & 8 & 16,7 & - & - \\
\hline $\begin{array}{l}\text { De } 19 \text { anos e } 6 \text { meses a } 19 \text { anos e } 11 \\
\text { meses }\end{array}$ & - & - & - & $\mathbf{1 0 0}$ \\
\hline Total & $\mathbf{4 9}$ & $\mathbf{1 0 0}$ & $\mathbf{0 6}$ & \\
\hline
\end{tabular}


Chama atenção que $12,5 \%$ ficaram grávidas pela segunda vez antes dos dezesseis anos e 16,7\% entre os dezenove e vinte anos. Destaca-se também, que a terceira gravidez ocorreu para $83,3 \%$ dos dezoito anos aos dezoito anos e 11 meses.

Se para $47 \%$ das mães adolescentes a primeira gravidez foi desejada/planejada, a segunda assim foi para apenas 28,6\%. Já a terceira gravidez, nenhuma delas disse tê-la desejado/planejado. Ou seja, grosso modo, o desejo pela maternidade não resistiu ao segundo filho.

Tamanha 'decepção' com a maternidade pareceu relacionar-se a uma série de condicionantes, mas o que primeiro percebemos como conflituoso foi o fato da nova maternidade ter ocorrido logo após o nascimento do primeiro filho. Sara comentou:"eu só imaginei com um segundo filho depois que tava grávida, eu não queria, eu escondi, fiquei com medo dos meus pais, o primeiro era ainda muito novinho e ainda tinha acabado de me separá, a primeira pessoa que comecei a saí já engravidei de novo”. Mariane lamentou: “eu não queria, minha nenê é muito novinha ainda".

A tabela 33 apresenta o intervalo de tempo entre partos $\left(1^{\circ}\right.$ e $\left.2^{\circ}\right)$ e novas gravidezes $\left(2^{\mathrm{a}}\right.$ e $\left.3^{\mathrm{a}}\right)$. Merece destaque que, quando a segunda gravidez ocorreu, 6,2\% das mães adolescentes, ficaram grávidas, provavelmente, no primeiro período fértil após o parto. Daiane falou a esse respeito e o quanto isso alterava seus planos: "eu não queria, a nenezinha estava mamando ainda, pensava em ter outro daqui a uns três anos, o plano era o marido ficá com a nenê para eu i estudá, agora com dois filhos vai complicá”. Vanessa, por sua vez, falou: "queria, só que depois eu não queria, cuidá de dois filho, tê responsabilidade, é muita coisa prá aprendê tão rápido, eu não tenho idade ainda”.

A análise das informações da tabela abaixo permitiu concluir que, após o primeiro parto, 33,3\% estavam grávidas pela segunda vez antes de um ano, $79,2 \%$ antes de dois anos. Somente $20,8 \%$ levaram mais de dois anos para a nova gravidez. 
Tabela 33 - Tempo entre parto e a nova gravidez entre adolescentes com maternidades sucessivas em Rondonópolis-MT, 2007.

\begin{tabular}{lcccc}
\hline & $\begin{array}{c}\text { Primeiro parto/Segunda } \\
\text { gravidez }\end{array}$ & \multicolumn{2}{c}{$\begin{array}{c}\text { Segundo } \\
\text { parto/Terceira gravidez }\end{array}$} \\
\hline Intervalos & $\mathbf{N}$ & $\mathbf{\%}$ & $\mathbf{N}$ & $\mathbf{\%}$ \\
\hline Menos de 5 meses & 03 & 6,2 & - & - \\
\hline De 5 a 8 meses & 06 & 12,5 & 03 & 50, \\
\hline De 9 a 12 meses & 07 & 14,6 & - & - \\
\hline De 13 a 16 meses & 10 & 20,8 & 01 & 16,66 \\
\hline De 17 a 20 meses & 09 & 18,8 & - & - \\
\hline De 21 a 24 meses & 03 & 6,2 & 01 & 16,66 \\
\hline De 25 a 28 meses & 05 & 10,4 & - & - \\
\hline De 29 a 32 meses & 04 & 8,3 & - & - \\
\hline Mais de 32 meses & 01 & 2,1 & 01 & 16,66 \\
\hline Total & $\mathbf{4 8}$ & $\mathbf{1 0 0}$ & $\mathbf{0 6}$ & $\mathbf{1 0 0}$ \\
\hline
\end{tabular}

Após o segundo parto, $50 \%$ estavam grávidas pela terceira vez em menos de um ano e 83,3\% em menos de dois anos. Apenas 16,6\% levaram mais de dois anos para a nova gravidez.

Nas falas das adolescentes, o que se observou também, é que a nova maternidade surgiu a despeito de certo planejamento que tinham ou que gostariam de ter. Patrícia esclareceu: "eu tinha um plano de ter um outro, mas não era agora”. Também Santina explicou: "queria outro filho, mas não achava que era esse o momento".

Contudo, para algumas o planejamento se pautava por ter apenas um filho. Gláucia disse: "não pensava, agora não, antes pensava em ter um casal, mas depois dela, eu mudei por causa da dor que senti no parto, eu não queria mais”. Raquel afirmou: “eu não queria, só queria o primeiro memo”. Priscila foi muito clara e falou: "eu não queria, não tinha plano, o plano era só o primeiro, foi uma gravidez indesejada, mas agora que já está, é desejar prá nascer com saúde”.

Nessas circunstâncias, planejar deveria ser sinônimo de uso de algum método contraceptivo e, de fato, as referências ao uso são consideráveis, 85,7\% disseram que usaram contraceptivos entre o primeiro parto e a segunda gravidez. 
Desse grupo, $81 \%$ referiram ter usado pílula, 16,6\% preservativos e, 2,4\% anticoncepcional injetável.

Entre o segundo parto e a terceira gravidez, $83,3 \%$ referiram ter feito uso de contraceptivos, das quais, $80 \%$ disseram usar pílula e, $20 \%$ preservativos. Chama atenção que $16,7 \%$, após dois filhos, não tenham se preocupado com uma terceira gravidez, alguma infecção sexualmente transmissível (IST).

Salvo uma ou outra que, deliberadamente, deixou de usar contraceptivos nesses períodos, a questão paradoxal que surgiu foi por que ficaram grávidas se estavam usando contraceptivos? Entre as que usavam pílulas, muitas puseram em dúvida a eficácia do medicamento. Embora saibamos que muitas dizem usar corretamente, mas não usam, é de estranhar que a gravidez tenha ocorrido com tantas mulheres.

Mas para além da questão relativa ao curto período entre um parto e a gravidez seguinte, outras situações surgiram como conflituosas.

Algumas se arrependeram de terem ficado grávidas novamente do parceiro que julgavam ser o errado. Daniela contou: "eu tinha vontade de tê um segundo filho, mas não com ele, queria ter uma situação melhor, até hoje não me conformo, dá uma tristeza, eu não queria”.

Outras lamentaram porque o novo filho não é do parceiro anterior, pai do outro filho e com isso, expuseram o drama que estão vivenciando. Aline falou: "não pensava em ficá grávida de novo, meu outro nenê ainda é muito novo, ainda gosto muito do meu ex-marido, tinha esperança de voltá com ele, agora fiquei grávida de outro”. Também Fernanda estava inconformada: "não queria, essa segunda vez foi péssima, a primeira não foi nem a metade do que está sendo essa agora, dá primeira vez eu tava junto com o pai do bebê e gostava dele pelo menos".

Para Silvana, o parceiro, pai do segundo filho lhe era estranho e por isso não queria o filho: "não queria ficá grávida de novo, não pensava em ter um segundo filho, a gente se conhecia tinha pouco tempo".

Houve ainda, outras adolescentes que não queriam a nova maternidade, porque percebiam suas dificuldades sócio-econômicas. Claísa explicou: "eu não queria agora não, pensava em ter outro filho, mas agora não, 
eu tenho que ter o mínimo de filho, dá vontade de jogá janela afora”. Marciane, por sua vez, falou: "me preocupei um pouco com dinheiro também”.

Também pensando nas condições econômicas, Judite, esclareceu: “não pensava nem um pouquinho, só com ela a gente já passa apertado, imagina com dois e a gente ainda não sabe se vai vir com saúde, e se não vir”. Geórgia também comentou: “a nenê estava muito pequena ainda, a gente nem tem casa, agora com dois filhos, sou muito nova".

Mas houve também aquelas que, embora na segunda gravidez, insistiam que nunca desejaram ter filhos. A esse respeito, Laíze falou: "eu não tinha planos, nunca quis, nem na primeira vez eu queria”.

Márcia, por sua vez, queria ter produção independente: "eu não queria, em nenhum momento queria a segunda gravidez, nunca pensei em casá depois do primeiro filho, pensava em arrumá um reprodutor para ter um segundo filho e não casa, isso por causa do que aconteceu no primeiro filho, só que arrumei um reprodutor antes da hora”.

Contudo, a despeito dessas razões, muitas adolescentes 'queriam um segundo filho'. Anaclara contou de seus planos: "eu queria, sentia falta de um bebê, eu via as outras com bebê, batia uma saudade, o meu já estava grande”. Fabiana disse: "nessa segunda eu queria ficá grávida, pensava em tê um menino homem e ai engravidei”. Sílvia explicou: "eu queria, tinha planejado a gravidez”. Célia planejou: “eu queria o segundo filho, até tinha deixado de usar anticoncepcional". Lara ficou eufórica com o segundo filho: "eu queria, eu tava morando com ele, tava junto, eu adorei a gravidez".

Outras queriam a nova maternidade, mas imaginavam que seria depois de algum tempo, após o primeiro filho 'ter mais idade'. Rose disse: “eu não queria ter um segundo, pensava que seria só depois de uns sete anos depois da primeira". Rafaela falou de como eram seus planos: "não queria, queria só uma, pensava em ter o segundo, terceiro com 23, 24 anos, não agora, queria terminá os estudos, trabaiá, ser professora de matemática, prá depois ter filhos, mas já que veio”. Gesane lamentou: “não queria, gostaria de ter um segundo filho, mas não agora, era bem mais prá frente”. 
Assim como na primeira gravidez, as 'pressões sociais pela maternidade' parecem existir para o segundo filho e trazem a idéia de que ter apenas um filho beira a incompletude materna. A esse respeito, Jocilene diz: "queria um segundo filho, mas uma menina". Luiza pensou igual: “queria ter outro, ter um casal, um menino”.

Luciane explicou melhor esse 'ideal materno', que parece misturar 'maternidade e psicologismo': "queria, porque só um filho ele se sentiria muito sozinho, dai agora ele aprende muito a dividir coisas com a irmã, acho que vai ser bom prá ele”. O segundo filho é acompanhante do primeiro, que por sua vez, acompanhava a mãe, como se fossem filhos amuletos. Sobre isso, Leocádia falou: "eu queria outro prá crescê junto com ele, ele sente falta".

Contudo, outras tiveram que ceder às 'pressões do parceiro'. Mayara contou sua saga: "queria, mas não agora, dava trabaio prá usá o anticoncepcional, tinha que tomá escondido porque ele queria tê um filho e eu não queria, ele ficava bravo de eu tomá injeção, ele queria tê um filho comigo prá morá com a gente”. Para Marciane, algo parecido aconteceu: "não queria agora, ele queria, eu queria esperá até que meu bebê tivesse uns três anos". Também Fabiana sentia-se pressionada a dar um filho ao parceiro: "eu não queria, era mais ele que queria”.

Identificamos que muitos dos parceiros que pressionavam as adolescentes pelo segundo/terceiro filho eram recém parceiros, alguns que não tinham filhos ainda e desejavam ter um filho e outros que já tinham filho, mas não com a atual parceira.

Mas também entre os parceiros com os quais já tinham filhos, pressões pelo segundo/terceiro filho existiam. Arícia contou: "ele queria prá família cresce, tê mais companhia”. Diferentemente dessa situação, algumas queriam o segundo filho apesar da 'oposição do parceiro'. Raquel contou: "eu queria, sentia saudade de quando a nenê era pequena, falava de ter um outro filho com meu marido. Ele falava que eu era doida, falou que filho não amarra marido. Eu penso em voltá com ele, vai ser melhor para as meninas, ser mãe solteira é ruim demais, ainda mais com guria mulher". 


\subsection{3 - As Preocupações da Segunda e Terceira Maternidade}

Ao relatarem sobre a descoberta de cada gravidez, as adolescentes falaram de uma porção de preocupações, que convimos tomá-las em consideração. Entretanto, antes de avançarmos, chamou atenção que para algumas a nova condição não despertava tantos conflitos. Anaclara comentou: "não tive nenhuma preocupação”. Nures acrescentou: "não tive nenhuma, já estava acostumada com o outro, tive menos preocupação que da primeira vez”.

Ainda a esse respeito, Luiza disse: "não me preocupei, achei normal, queria ter outro”. Joelma pareceu indiferente: “não me preocupei não, já que veio, fazer o quê". Sílvia mostrou-se despreocupada, mas surpresa: "não me preocupei porque a primeira foi tranqüila, eu achava que não ia engravidá, fiquei surpresa, achei que não engravidaria mais". O planejamento deu segurança a Leocádia: "não tive nenhuma preocupação, a gente tinha planejado”.

Entretanto, diferentemente dessas adolescentes, que de certa forma, mostraram-se satisfeitas com a nova maternidade, 71,4\% mostraram-se preocupadas com a segunda maternidade e todas as que estavam grávidas pela terceira vez, demonstraram-se apreensivas e insatisfeitas com a situação.

Uma constelação de preocupações tinha como eixo central a 'própria condição', que de certa forma, parecia pautar-se pela seguinte reflexão: 'como que eu vou fazer para cuidar dos filhos?' Aliás, essa questão apresentou-se como crucial para muitas adolescentes. Santina se perguntou: "como que eu vou tê que cuidá dos dois filhos".

Luzia também se questionou: "pensei em como que cuidaria de duas crianças". Mariane, por sua vez, parecia sentir-se impotente: " $a$ minha preocupação foi com a dificuldade de cuidá do nenê, só com um fio já passo um apuro, imagina a hora que nascê o outro".

Para Rose, o conflito era de outra natureza: "nem terminei de criá essa aqui e já vou tê outro, a minha atenção vai tê que repartir”. Priscila também parecia não saber o que fazer: "fiquei preocupada porque já tava grávida de outro e ainda separada, como sustentá duas criança”. 
Maira, por sua vez, pensou na sua escolarização: "fiquei preocupada em como que ia para a escola com aquela barriga”. Como ir aos lugares também preocupou Vanessa: “como i nas festas, sempre quis tê outro filho, mas no futuro, vi que agora o filho vai atrapalhar um pouco, vou ter que ter mais responsabilidade”.

A 'pouca idade' foi outra condição das adolescentes que também despertou suas preocupações. Geórgia disse: "a nenê tava muito pequena, a gente nem tem casa, agora com dois filhos, sou muito nova e já tenho dois filhos”.

Para essas mães, a nova gravidez suscitou uma outra preocupação, na verdade, um antigo conflito, o 'medo dos familiares não as aceitarem grávidas de novo'. Marcilene ficou com medo do pai: "fiquei preocupada do meu pai querê me mandá embora de casa, a nenê tava dando trabaio também, fiquei com muito medo do meu pai". Sara, por sua vez, ficou com medo da mãe: "eu escondi, fiquei com medo da minha mãe, dos meus pais, o primeiro era muito novinho, tinha acabado de me separa, a primeira pessoa que comecei a saí, já engravidei de novo”.

Raquel teve que ouvir os comentários dos familiares: "perguntaram por que estava separada, se não era do mesmo pai, minha família, eles não aceitou essa segunda gravidez, falaram que eu podia ter me cuidado, evitado de ficá de outra pessoa”.

Várias outras ficaram com medo de 'perder o apoio familiar', de não contarem com esse suporte. Tal preocupação pareceu juntar-se com a noção de que atrapalham a vida dos familiares e que, com mais um filho, o atrapalho seria maior. Assinala, também, o quanto muitas são dependentes dos familiares para que possam criar os filhos.

Jussiane ficou muito incomodada: "o meu pai está desempregado, como que vou fazê? Fabrícia também se preocupou: "fiquei preocupada com minha mãe e com meu padrasto, falá de novo que estava grávida, já estou morano com eles e agora? Para Jéssica, o apoio familiar tinha um prazo: "minha preocupação é que vou tê que morá com ele, a responsabilidade vai dobrá, minha mãe quer me mandá embora pra morá com ele, disse que vai esperá até o terceiro mês pra mim resolvê. 
Pelo observado, uma das grandes preocupações das adolescentes referia-se à 'condição do parceiro'. A esse respeito, Bárbara destacou o desemprego do marido: "a preocupação foi maió em tudo, tudo é diferente da primeira, tipo aluguel, antes eu não pagava, morava com a mãe, agora ele (o marido) está sem serviço, um dia trabaiando e dois parados e agora a outra nenê". O desemprego do marido também assustou Célia: "não tive preocupação nenhuma, a gente estava com plano, só que antes ele tava trabalhando e quando fiquei grávida ele perdeu o emprego, isso me deixa preocupada, como comprá as coisa do nenê"”.

Para Mayara, a grande preocupação era tirar o marido da cadeia. Disse ela: "e agora, o que vou fazer da minha vida com meu marido preso e eu grávida de novo". Jocilene fez comentários semelhantes de seu parceiro: "eu fiquei menos assustada que da primeira, só fiquei assustada por ser dele, ele não presta, sabe, me arrependo dele ser o pai de meus filhos, não de ter tido eles".

Para Denise, o que incomodava era a relação que não mais mantinha com o parceiro: "pensei tanta coisa, era recente que tinha separado, tinha esperança de voltar com o meu marido”. Gláucia, por sua vez, submetia-se ao parceiro: "nossa, esse eu fiquei preocupada, a gente tava separado, eu pensava o que eu ia fazê com dois filhos e sem marido, como trabaiá, até que tive que dá o braço a torcer e vim morá aqui com ele”.

O medo de 'ser abandonada' pelo parceiro foi outra preocupação registrada. Adna comentou: "preocupei se ia dá certo ficá com ele, se não ia acontecê o memo que aconteceu com o outro, me abandona”. Entretanto, ser efetivamente abandonada, pareceu preocupar mais. Cíntia falou: “ai, tudo foi preocupação, agora que o outro já tinha crescido, eu tava trabaiando, fiquei grávida de novo, ele não quis assumir, falou que não era dele, me ameaçava, falou que ia me matá”.

Outra categoria de preocupações se pautou pela aparente 'indignação com a nova gravidez', tendo em vista, que o filho anterior ainda era 'muito novo'. Patrícia mostrou-se inconformada: "eu não queria não, eu tava muito nova ainda, o outro estava muito novo". Judite explicou melhor: "minha preocupação foi com ele porque ela tá pequenininha ainda, agora mais um prá dá atenção, ela está 
numa fase de aprendê comigo, como vou cuidar dele”. Indignada, Daiane contou sobre seu plano: "fiquei muito preocupada, a nenezinha estava mamando ainda, pensava em ter outro filho daqui uns três anos".

Também Lea se mostrou frustrada em seus planos: "eu nem construí minha filha direito e olha, já estou grávida de novo, fiquei preocupada com isso, ela está muito novinha, eu falava que queria ter outra só depois de três, quatro anos. Gesane, por sua vez, fica admirada consigo mesma: "nossa, como foi difícil saber que estava de novo grávida, o guri tava pequeno ainda”.

Outro tipo de preocupação surgida são aquelas de 'ordem médicas'. Fátima comentou: "fiquei preocupada com o dia do parto, ainda tou com medo do dia de parto, quero tê normal, mas tenho medo de dá alguma coisa errada, de passá o tempo de nascê. Marciane disfarçou a preocupação: "tenho uma preocupaçãozinha com a hora de ganhá”. Márcia por sua vez, relacionou fatos e riscos: "pensei logo que se estava grávida eu podia ter pego alguma doença, depois que eu pensei em como que ia cuidá do filho".

\subsection{4 - As Adolescentes e as Tentativas de Provocar o Aborto}

Um desfecho para o imprevisto que se configurou a gravidez para várias adolescentes pautou-se pela possibilidade de provocar o aborto. A Tabela 34 apresenta as informações relativas aos percentuais de adolescentes que pensaram, planejaram ou tentaram provocar o aborto em uma ou mais gravidezes.

Tabela 34 - Intenção de provocar aborto entre adolescentes com maternidades sucessivas em Rondonópolis-MT, 2007.

\begin{tabular}{lccc}
\hline & Primeira Gravidez & Segunda Gravidez & Terceira Gravidez \\
\hline Categoria & $\%$ & $\%$ & $\%$ \\
\hline Teve intenção & 24,5 & 28,6 & 33,3 \\
\hline Não teve intenção & 75,5 & 71,4 & 66,7 \\
\hline Total & $\mathbf{1 0 0}$ & $\mathbf{1 0 0}$ & $\mathbf{1 0 0}$ \\
\hline
\end{tabular}


Chama atenção, que se na primeira gravidez, uma em cada quatro adolescentes teve a intenção de abortar, na terceira gravidez, a proporção subiu para uma a cada três. A não aceitação da gravidez surgiu naquelas adolescentes que reagiram à gravidez como se essa fosse uma 'invasão do corpo', algo vivenciado com estranheza às entranhas do corpo.

A esse respeito, Aline falou: "eи fiquei com muito medo, revoltada, recusei a barriga uns quatro meses". Fernanda contou: "eu fiquei mais desesperada do que na primeira vez porque a médica disse que eu não podia ficá grávida, eu não aceitava esta gravidez porque eu já tinha um filho, ele nem mora mais comigo, só aceitei agora no último mês”. Mariane, por sua vez, relatou: “chorava, queria tomar remédio para abortar, saí xingando do posto de saúde, eu sentia que era moça demais, com medo do meu corpo fica feio, não ficava pensando nisso depois que eu fui aceitando”.

O aborto provocado surgiu como uma possibilidade ora fantasiosa, ora real de 'expulsar' tamanho incômodo. Bárbara disse: “dessa segunda vez eu fiquei traumatizada, não tava esperando, nem estava na hora, pensei em abortar, passou pela minha cabeça, mas tem que pensar no outro lado, eu que devia ter me cuidado”. Daniele "eu não aceitava a barriga, por isso pensei em tirá”.

Contudo, provocar o aborto foi para muitas apenas uma possibilidade, uma idéia, senão, uma fantasia. Aline disse: "só pensei não cheguei a tomar nada não”. Daniele falou: “pensei mais desisti”. Mariane comentou: “pensei, mais não fiz nada”. Fernanda, por sua vez, contou: “pensei várias vezes, dai desisti, já que tô grávida memo”. Denise pensou junto com o parceiro: “nos pensamos mais não tomei remédio nenhum".

Luiza ficou com medo: "cheguei a pensar, mais eu vi que minha tia fez aborto e quase morreu, ai eu pensei melhor”. Também o medo de abortar, impediu Patrícia: “pensei em abortá, mais não tive coragem”.

Fernanda seguiu vários conselhos: "uma amiga me aconselhou a abortá, um monte de gente falava prá eu fazê isso, mas minha mãe e minha irmã me aconselhou muito, dai desisti”. Também Santina seguiu as orientações da mãe: “eu pensei, minha mãe que não deixou”. 
Para outras, a idéia virou um plano, que na verdade, não se concretizou por diversos motivos. Denise explicou seu plano e porque não deu certo: "pedi remédio pra ele, prá abortá, mas era caro, pedi prá ele comprá mais ele não comprô, no começo, essa gravidez foi indesejada porque ele não queria comprá o remédio, ele sabia que eu queria o remédio prá tirá”.

Também Bárbara contou o que aconteceu e planejava: “dessa segunda gravidez eu fiquei traumatizada, não tava esperando, nem tava na hora, pensei em abortá, passou pela minha cabeça, mas tem que pensá pelo outro lado, eu que devia tê me cuidado, logo que ganhei ela comecei a usá anticoncepcional e, camisinha, quando não tinha anticoncepcional, eu engravidei dessa segunda vez usando camisinha, sorte que eu fiz o exame, se não eu tinha jogado o nenê fora, eu ia tomá raizada, um remédio forte prá inflamação e que faz descê, ia tomá buchinha também”.

Laize ensinou como planejava preparar o abortivo: "Eu pensei antes de recebê a confirmação da gravidez, eu ia tomá 'pega pinto', é para inflamação, mas ele faz descê (abortar), ia tomá isso, é só bater no liquidificador e tomar”.

As adolescentes que efetivamente tentaram abortar descreveram suas experiências sem relatarem maiores conseqüências. Todas que tentaram não foram bem sucedidas no intento, nem tiveram complicações. Provavelmente, as que conseguiram provocar o aborto ou tiveram problemas decorrentes da tentativa, não iniciaram o pré-natal e, por isso, não foram selecionadas para a pesquisa.

As descrições das tentativas de abortamento pareceram bulários da 'medicina caseira', que, aliás, parece contrapor-se aos 'medicamentos da farmácia ou do Paraguai': Cíntia contou como tentou abortar: "tomei bastante remédio prá abortá, mas remédio caseiro, fedegoso, pitoco, São Caetano, buchinha, de farmácia eu tomei a pílula do dia seguinte, mais fazia mais semana $i$ não adiantô".

Lara também contou como fez: "tomei uns remédio, chá de buchinha, mais não adiantou nada". Mayara comentou: "Eu tomei chá do boldo, mas não resolveu”.

Vanessa, por sua vez, parece ter inventado um 'abortivo' muito particular: "eu queria abortá, mas tentei mi matá, ia tomá morfina, mas não tive 
coragem, tomei pinho sol, mais não resolveu nada”. Rose também parece ter inventado o seu 'abortivo': "pensei, tomei anticoncepcional com pinga queimada com raízes, bebi e injetei o anticoncepcional, mas não adiantou”. O uso de algumas práticas abortivas pareceu ser costume natural em alguns grupos familiares. Priscila explicou: “deu a loucura de abortá, mas a consciência pesou, cheguei a tomá uma raizada com pata de vaca, minha vó falou que era bom prá derrubá, mas não derrubô, foi minha vó que mais mi influenciou”.

Daniela, por sua vez, contou com a madrasta: "pedi pra minha madrasta fazer um sumo bem forte, uma raizada né, mas não desceu, eu falei que queria tirá, tomei sumo de algodão, mastruz, São Caetano, tem hora que dá vontade de tirá ainda”. Quando Joelma revelou a gravidez aos familiares, a sogra interveio: "a mãe dele queria que eu tirasse".

Os parceiros também colaboraram para a tentativa de abortamento. Márcia explicou: "eu não pensei mais meu namorado conseguiu citotec e queria que eu usasse, ele falou que o aborto seria melhor pra os dois, fiquei magoada com isso ele mudou muito”. Finalmente, uma motivação que pareceu perpassar as idéias, planos e tentativas de provocar o aborto referiam-se muito mais as dificuldade econômico-sociais do que a qualquer outro aspecto. A esse respeito, Luiza comentou: "pensei em fazê por causa da minha situação financeira". Também Maria pensou assim: "eu falei de fazê o aborto, era muito filho, mas desisti”.

\subsection{5 - A Relação das Adolescentes com o Pai do Filho}

A caracterização dos vínculos estabelecidos pelas adolescentes requer certo cuidado. Optamos por caracterizá-las independente das categorias comumente proporcionadas pelo referencial 'estado civil', como casada, solteira, desquitada e adotamos a noção de parceria 'fixa' e 'eventual'. 
Definimos a primeira como a relação afetiva caracterizada por mínima estabilidade e compartilhamento de compromissos comuns em determinado período de tempo, independentemente de fidelidade sexual. Não se enquadram nessa acepção, as parcerias eventuais, caracterizadas por serem relações episódicas, sem laços afetivos e dispersas no tempo.

Entretanto, se conceitualmente isto dá maior flexibilidade para refletir a natureza das relações que as adolescentes estabeleceram com o(s) pai(s) de seu(s) filho(s), na prática, a noção de casamento (estado civil) foi a que balizou a forma como elas se referiram às suas parcerias sexuais e afetivas. Diziam que eram casadas, mas logo em seguida, corrigiam a informação, pois, na verdade, estavam amasiadas, 'juntadas', 'morando junto', 'namorando', 'ficando'.

Ou seja, para muitas, o casamento parecia conservar-se como a maneira 'correta' ou idealizada de se relacionar. Afirmaram que estavam casadas, morando juntos, por ocasião da segunda maternidade, $67,3 \%$ e da terceira, $50 \%$. Aline comentou: "depois que nós fugimo nós casamo, quer dizer, fomo morá junto”. Maria disse: "nós tamos juntos há cinco anos, mas não casamo ainda”.

Também a concepção de namoro, embora conservasse o seu caráter de preparação para o casamento pareceu condensar vários outros elementos, incluindo a própria maternidade e a criação dos filhos sem que deixasse de ser namoro. Jéssica falou: “depois que nós tivemo ele, nós continuamo namorando”. Explicaram que estavam namorando na oportunidade da segunda maternidade, $28,6 \%$ e da terceira, $50 \%$.

Aliás, observamos que muitas julgavam que estavam namorando ou queriam continuar o namoro, aparentemente, como tentativa de manter a tríade 'pai-mãe-filho', mas era notório que não existia mais vínculo na relação, ao menos por parte do parceiro. Sara disse: "enquanto eu tava grávida ele vinha me ver, mas agora ele foi trabaiá no mato e não sei quando volta, não sei prá onde ele foi".

Mas, diferentemente desses casos, muitas sentiram a necessidade de mudar a natureza do relacionamento com a maternidade. Lea disse: "resolvemos $i$ morá junto depois que ele nasceu”. 'Morar junto' é por sinal, a expressão que 
parece conseguir abarcar a intensidade da relação, independente da forma como se organize e, parafraseando o poeta, 'do enquanto dure'.

O parceiro de Sílvia, que acompanhava a conversa, falou: "quando a gente se conheceu, foi assim, no ato, ela falou que queria morá comigo, eu achei que era brincadeira dela, a hora que eu vi ela estava chegando em casa com a roupa dela, foi dai que a gente arrumô este barraco”.

Geralmente, 'morar junto' implicou para as adolescentes muitas responsabilidades. Pareceu-nos que é 'mais sério que casamento', pelo menos por parte delas. Observamos que, por vezes, isso obriga a ir para um 'grilo', construir um barraco, alugar uma casa, mudar para a casa de um parente, conseguir emprego, enfim, dar nova organização para a vida. Esses desafios parecem contar com a solidariedade do grupo familiar, que muitas vezes, cedem o fundo do terreno para a construção ou ajudam com outras coisas. A esse respeito Fabiana comentou: "eles deixam almoçá lá".

Outro tipo de relacionamento é aquele marcado pela provisoriedade do vínculo. Em outras regiões, é chamado de 'ficante' e se caracterizam pela ausência de qualquer compromisso. Observamos que esse tipo de relacionamento também ocorre, entretanto, apesar de não ter o compromisso, pareceu ser uma forma que as adolescentes encontravam de reatar um vínculo com um exnamorado ou ex-marido. Como também nessa modalidade há relações sexuais e muitas ocorrem sem proteção, algumas ficaram grávidas em parcerias dessa natureza.

A partir do conceito de parceria eventual, se enquadrariam nessa categoria as adolescentes que, por ventura, trabalhassem como garotas-deprograma, entretanto, embora as agentes comunitárias de saúde fizessem alusão a essa forma de trabalho no bairro, nenhuma declarou tal condição.

Os tipos de parcerias adotados pelas adolescentes parecem refletir diretamente sobre a forma como organizam a vida sexual. A esse respeito e contrariamente à idéia corrente de que adolescentes grávidas, assim estão, porque são sexualmente promíscuas ou têm uma vida sexual desembaraçada, encontramos que $67,4 \%$ delas ficaram grávidas a partir de única parceria sexual, $20,4 \%$ numa segunda parceria e apenas $12,2 \%$, numa terceira ou mais parcerias. 
Talvez, inversamente à concepção de promiscuidade, tenhamos que trabalhar com a idéia de inexperiência e até ingenuidade sexual.

Também o tempo de parceria até que ficassem grávidas (Tabela 35) indica o caráter, aparentemente, estável dessas parcerias. Aliás, a temporalidade parece ser uma dimensão que é vivenciada de forma amplificada. Com dezessete, dezoito anos, referiam ao 'antigamente' como se fosse um tempo muito distante, mas, na verdade, só queriam dizer do que aconteceu aos quinze. Também para se referirem à longevidade dos eventos parecem usar a mesma lógica. Arícia comentou: não foi logo que transei com ele, foi depois de um mês. Maria disse: “levou tempo prá mim ficá grávida, fazia uns dois meses que a gente namorava”.

Tabela 35 - Tempo de relacionamento com o pai do primeiro filho até que ficasse grávida pela primeira vez em adolescentes com maternidades sucessivas em Rondonópolis-MT, 2007.

\begin{tabular}{lcc}
\hline Período & N & \% \\
\hline Menos de 2 meses & 9 & 18,4 \\
\hline 2 a 6 meses & 13 & 26,5 \\
\hline 7 a 12 meses & 14 & 28,6 \\
\hline Acima de 13 meses & 13 & 26,5 \\
\hline Total & $\mathbf{4 9}$ & $\mathbf{1 0 0}$ \\
\hline
\end{tabular}

Essas informações permitem observar que há uma distribuição relativamente uniforme das ocorrências da gravidez ao longo do primeiro ano de parceria, sendo que 26,5\% ocorreram ao longo do segundo ano. Apenas 18,4\% ocorreram antes do segundo mês de parceria.

Outra informação que corrobora a hipótese de que há certa estabilidade nessas parcerias sexuais é a de que apenas $16,3 \%$ das gravidezes ocorreram na primeira relação com o parceiro pai do filho. Outras 12,2\% ocorreram após poucas relações sexuais (duas a seis) e a grande maioria, 71,5 \%, após seis ou mais relações sexuais.

Também o tempo de parceria verificado quando houve a segunda gravidez evidencia de igual modo a perenidade das parcerias, conforme apresentado na Tabela 36. Se na primeira gravidez, 26,5\% estavam a mais de 12 meses em parceria fixa, na segunda gravidez, o percentual subiu para $71,4 \%$. 
Tabela 36 - Tempo de relacionamento com pai do segundo filho até que ficasse grávida pela segunda vez em adolescentes com maternidades sucessivas em Rondonópolis-MT, 2007.

\begin{tabular}{lcc}
\hline Período & N & \% \\
\hline Menos de 2 meses & 07 & 14,3 \\
\hline 2 a 6 meses & 05 & 10,2 \\
\hline 7 a 12 meses & 02 & 4,1 \\
\hline Acima de 13 meses & 35 & 71,4 \\
\hline Total & $\mathbf{4 9}$ & $\mathbf{1 0 0}$ \\
\hline
\end{tabular}

A investigação da experiência sexual com o parceiro, pai do segundo filho apontou que 93,7\% das mães adolescentes tiveram com eles mais de seis relações sexuais até que ficassem grávidas novamente. O percentual é tão elevado porque poucas estavam em novos relacionamentos, apenas $14,3 \%$.

Contudo o mesmo raciocínio não pode ser estendido às informações referentes à terceira gestação, por um lado porque o número de participantes (06) nessas condições foi relativamente pequeno em relação às demais (43) e, por outro, porque pareceram apresentar características muito peculiares. A Tabela 37 apresenta as informações e sobressai a de que nenhuma ficou grávida logo que iniciou a parceria, mas metade assim ficou antes dos seis meses de relacionamento.

Tabela 37 - Tempo de relacionamento com o pai do terceiro filho até que ficasse grávida pela terceira vez em adolescentes com maternidades sucessivas em Rondonópolis-MT, 2007.

\begin{tabular}{lcc}
\hline Período & N & \% \\
\hline Menos de 2 mês & - & - \\
\hline 2 a 6 meses & 03 & 50 \\
\hline 7 a 12 meses & 01 & 16,6 \\
\hline Acima de 13 meses & 02 & 33,3 \\
\hline Total & $\mathbf{0 6}$ & $\mathbf{1 0 0}$ \\
\hline
\end{tabular}

Entretanto, 83,3\% referiram que tiveram muitas relações sexuais (acima de 6) com o pai do terceiro filho até que ficassem grávidas e apenas 16,6\% afirmaram terem ficado grávida na primeira relação com o novo parceiro. Avaliaram como sendo parceria fixa a que estavam quando ocorreu a terceira 
gravidez, 66,6\% . A partir dessas informações, investigamos a 'quantidade de pais dos filhos', conforme apresentado na Tabela 38.

Tabela 38 - Número de parceiros, pais dos filhos de adolescentes com maternidades sucessivas em Rondonópolis-MT, 2007.

\begin{tabular}{lcc}
\hline Quantidade & N & $\mathbf{\%}$ \\
\hline Filhos com único pai & 30 & 61,3 \\
\hline Filhos com mais de 1 pai & 19 & 38,7 \\
\hline
\end{tabular}

Foi levantado também como as participantes caracterizavam sua vida sexual em relação ao número de parceiros sexuais, conforme mostra a Tabela 39. Chamou atenção que 'diversas parcerias sexuais', na verdade, não se pautou por grande número de parceiros sexuais. Entre aquelas que tiveram diversas parcerias sexuais, 34,4\% referiram ter tido relações sexuais apenas com os pais dos filhos, ou seja, dois ou três e, $65,6 \%$ disseram ter tido outros parceiros sexuais, que não os pais dos filhos. Dessas, somente 5,2\% mencionaram experiências sexuais com mais de dez parceiros. As demais, 94,8\% tiveram de um a cinco parceiros.

Tabela 39 - Número de parceiros sexuais de adolescentes com maternidades sucessivas em Rondonópolis-MT, 2007.

\begin{tabular}{llc}
\hline Número & $\mathbf{N}$ & $\mathbf{\%}$ \\
\hline Única Parceria Sexual & 20 & 40,8 \\
\hline Diversas parcerias sexuais & 29 & 59,2 \\
\hline Total & $\mathbf{4 9}$ & $\mathbf{1 0 0}$ \\
\hline
\end{tabular}

\subsection{6 - Reação do Parceiro Diante da Gravidez}

As reações dos parceiros à gravidez foram relatadas pelas adolescentes com considerável diversidade, desencadeadas, aparentemente, por vários motivos e conforme a quantidade de filhos que eles tinham ou não. Entretanto, agrupamos as reações em três grandes categorias e de acordo com a ordem de gravidez da parceira, conforme apresentado na Tabela 38. 
Tabela 40 - Reação ao saber da gravidez de parceiros de adolescentes com maternidades sucessivas em Rondonópolis-MT, 2007.

\begin{tabular}{lccc}
\hline Atitudes do parceiro & $\begin{array}{c}\text { Primeira } \\
\text { gravidez } \\
(\mathbf{\%})\end{array}$ & $\begin{array}{c}\text { Segunda } \\
\text { gravidez } \\
(\mathbf{\%})\end{array}$ & $\begin{array}{c}\text { Terceira } \\
\text { gravidez } \\
(\mathbf{\%})\end{array}$ \\
\hline Gostou/ficou alegre/contente & 63,3 & 59,2 & 50 \\
\hline Preocupado/surpreso/nervoso & 24,5 & 22,4 & 33,3 \\
\hline $\begin{array}{l}\text { Não 'ligou'/não assumiu, } \\
\text { 'sumiu' }\end{array}$ & 12,2 & 18,4 & 16,6 \\
\hline Total & $\mathbf{1 0 0}$ & $\mathbf{1 0 0}$ & $\mathbf{1 0 0}$ \\
\hline
\end{tabular}

Basicamente, pôde ser observado que reduziram as reações ligadas à 'satisfação pela gravidez da parceira' à medida que aumentou o número de filhos. Também as reações ligadas ao 'abandono da parceira grávida' foi maior na segunda e na terceira maternidade quando comparado ao ocorrido na primeira. As reações relativas "as preocupações/surpresas pela gravidez da parceira" diminuíram da primeira para a segunda maternidade, mas aumentaram, consideravelmente, da segunda para a terceira.

Chamou a atenção, o relato de algumas adolescentes. Referiram que seus parceiros, na ocasião da primeira maternidade, ficaram tão insatisfeitos ou indiferentes, que não assumiram o filho. Vanessa, ao referir-se ao pai de seu filho, explicou: "quando contei pra ele, falô que o filho não era dele, ele só aceitou quando vim embora, mas ele não assumiu até hoje”. Com Jéssica aconteceu algo muito parecido. Disse ela: "ele trouxe os pais para vir conversá, diz que assumiria, mas até hoje não veio vê ela".

Entretanto, a reação dos demais parceiros com a primeira gravidez da parceira, geralmente foi de entusiasmo. Na fala das adolescentes aparecem muitas referências que relacionam tal contentamento ao 'primeiro filho' do parceiro. Aline disse: "ele ficou feliz, foi primeiro filho". Fernanda contou: "ele ficou alegre e logo contou para a família, ele queria tê um filho".

Pareceu surgir a concepção entre os parceiros de que era necessário ser pai. Fabiana explicou: "ele ficou feliz, falou que ia ser pai pela primeira vez, o sonho dele era ser pai". O parceiro de Luciane tinha o mesmo sonho: "ele ficou muito feliz, porque era o sonho dele ter um filho". Também o parceiro de Lea pareceu seguir a mesma sina: "ele ficou feliz, queria ser pai, ele era doido para 
engravidá mulher por aì”. A fala de Sílvia pareceu explicar melhor: "ele saiu pulando de alegria, ficou chorando, ainda mais que era homem".

Entretanto, outros pais mostraram-se muito surpresos com a primeira gravidez. Rose contou sobre seu parceiro: "ele não acreditô, memo com exame, só quando a barriga cresceu e com os papel na mão, ficou nem contente, nem triste, ficou abalado". O parceiro de Célia também titubeou: "ele ficou meio estranho uma semana, a gente tava meio assim querendo se separá".

Outros parceiros se surpreenderam porque a gravidez não fazia parte dos seus planos. Denise contou a respeito de seu parceiro: "ele ficou surpreso, ele era novo também, não pensava em ter filhos”. Gesane, por sua vez contou: "ele ficou surpreso, porque nós não tava esperando, a gente estava programando de casá, estava terminano de terminá a casa”.

Algumas adolescentes relataram sobre parceiros assustados com a gravidez. Rafaela contou: "ele ficou assustado, com medo do meu pai, da reação dos outros". Medo foi o que também sentiu o parceiro de Fátima: "quando eu contei ele quase morreu de tanto tremer com medo do meu pai e da minha mãe ficá brava com ele”. Jocilene, por sua vez, revelou que não havia motivos para sustos, pois, claramente sabiam dos riscos envolvidos na parceria: "ele ficou assustado, mas ele sabia o que podia acontecer".

Houve parceiros, na primeira gravidez, que se preocuparam motivados pela avaliação das condições sócio-econômicas em que viviam. Mariane disse sobre seu parceiro: "ele ficou preocupado porque a gente não tinha casa". Também o parceiro de Rose ficou preocupado com as condições financeiras: "ele falou das nossas condições, aonde ia arrumá emprego, ai foi trabalá clandestino no corte da cana".

Finalmente, outros parceiros, embora preocupados e surpresos, mostraram-se dispostos a apoiar a parceira na gravidez que se iniciara. Cíntia, a respeito da reação de seu parceiro falou: “ele me deu todo apoio”. Claísa contou do parceiro: "ele falou que ia me apoiá e que não era prá abortá, ele ficou preocupado”. Já o parceiro de Geórgia disse: “agora vamos casá”. Contudo, nem sempre o apoio prometido foi suficiente para convencer as adolescentes. Mariane 
não aceitou o apoio prometido: "ele falou que era prá i embora com ele que ele ia ajudá, mas não fui não, comecei a tomá nojo dele”.

A respeito das reações de satisfação dos parceiros na segunda e terceira gravidez da parceira, de maneira geral, o contentamento foi explicitado pelas frases 'ele ficou feliz', 'pulou de alegria', 'gostou muito', seguida dos motivos da satisfação, que por sinal, variaram muito. O que pôde ser observado, é que como grande parte eram parceiros fixos, eles gostariam de ter outro filho, geralmente, para 'formar um casal' de filhos.

A esse respeito, Anaclara contou do parceiro: "ele ficou feliz, principalmente depois que ficou sabendo que é uma menina". O parceiro de Sílvia também queria formar um casal: "foi normal, ele queria uma menina". Outros parceiros pareciam querer uma família numerosa, como o de Lea: "ele gostou de novo, ele já qué tê o terceiro”. Entretanto, o de Arícia não queria tantos filhos: "ele ficou feliz, mas descobriu que eu não tomava o remédio, jogava fora, e ai ele ficou bravo de eu enganá ele”.

Contudo, embora para as adolescentes a atual gravidez não fosse a do primeiro filho, para alguns parceiros era. Foi isso que aconteceu com o parceiro de Fernanda; "ele ficou feliz porque ele falava que ia tê um filho comigo". O parceiro de Adna vivenciava a mesma situação: "ficou alegre porque ia ser o primeiro filho dele”. Já Denise, desconfiou das intenções de seu parceiro: “ele gostou, é novinho, mas tem aparência de mais velho, acho que ele pensou em fazê um filho pra eu ficá com ele”.

Por outro lado, como se observou na Tabela 40, o percentual de parceiros descontentes com a segunda e/ou terceira gravidez da parceira foi considerável. Os relatos das adolescentes revelaram que a insatisfação foi manifestada por eles de diversas formas.

Alguns se mostraram surpresos. Aline contou: "ele não tava esperando, ficou meio assim”. Já o parceiro de Maira se assustou: "ele levou um susto, falou: fio de novo!". Outros ficaram descontentes porque não queriam filhos. Sobre o parceiro, Daniele disse: "ele ficou meio chateado porque ele não queria, nem eu”. Também Claísa falou do parceiro: “ele nem falou nada, mas ele não queria ter outro filho". 
Houve relatos sobre aqueles parceiros que além de descontentes, não assumiram os filhos. Bárbara contou: "ele ficou brabo, falou que não era filho dele não, ele não acreditava". Cíntia disse: "na hora disse que ajudaria, não espantou não, mas para os outros falou que não era dele”. Daniela comentou: "ele não falou nada, só que o filho não era dele, falei que se ele quisesse acreditá, bem, senão, ele não vai cuidá memo". Lara, por sua vez, falou: "ele disse que ia ajudá, mas vazou, foi embora nunca mais vi”.

As condições sócio-econômicas também preocuparam diversos parceiros ao saberem da nova gravidez. O parceiro de Célia "ficou preocupado porque estava desempregado”. Rafaela, ao contar para o parceiro sobre a gravidez, disse: "ele ficou meio assustado por estarmos aqui na casa do pai dele, depois que ele acostumou com a idéia de tê duas filhas". Joelma, por sua vez, disse: "ele não falou nada, só que a gente não tava podendo com um, agora tem que vê leite prá dois".

Essa e outras preocupações parecem ter levados alguns parceiros ao desespero. A respeito das atitudes de seu parceiro, Raquel contou: "ficou triste, desorientado, me trancou dentro de casa, desde que engravidei não me deixou sair mais, eu respeito porque eu acho que assim ele vai voltá comigo, mas até agora só desprezo, no começo até que ajudou, depois que acostumou não me ajuda mais". De outra forma, o parceiro de Márcia foi mais direto. Disse ela: "ele falou que era prá abortá”.

Surpreendentemente, algumas atitudes dos pais foram orientadas pelo seu grupo familiar. Gláucia disse de seu parceiro: "ele ficou rindo da minha cara, minha sogra ficou braba, ela dava conselho pra não engravidá que o guri era pequeno ainda e dava muito trabalho". Sobre isto, Jéssica contou: "ele ficou desesperado por que o pai dele e a mãe não apoiou o que ele fez". 


\subsection{7 - Mudanças Trazidas Pela Maternidade}

Célia explicou com muita propriedade a 'metamorfose' pela qual passou: "virei mãe, isso que mudou, não sou mais aquela menina, eu era uma criança cuidando de outra criança, eu passei a senti que dava conta”. As adolescentes foram unânimes em relatarem que a maternidade modificou radicalmente suas vidas.

O constante uso das expressões 'mudou tudo', 'mudou muito', 'não posso mais’ parecem denotar a intensidade dessas transformações. A esse respeito Priscila explicou: "mudou tudo, uma criança na família muda tudo”. Marciane falou: “mudou bastante coisa, fiquei mais madura, diferente”. Sara, por sua vez, disse: "mudou tudo, cem por cento, as coisas que eu fazia não pode fazer mais, saí, i em festas". Também Rose comentou sobre as mudanças: "fiquei mais responsável, bastante coisa mudou, o jeito de pensá, de falá”.

Mas, curiosamente, a grande mudança pareceu relacionar-se com a 'privação da liberdade'. Não 'poder sair' foi uma expressão freqüentemente usada. Bárbara falou: "mudou tudo, a liberdade, a questão de saí, tive que trabaiá, a gente parece que amadurece”. Claísa, por sua vez, disse: “mudou tudo, desde minha liberdade, andava que nem lobinha, agora não pode mais saí, fiquei um pouco mais responsável, mas não foi muito não”.

Pareceu, portanto, que a gravidez e, conseqüentemente, a maternidade encerrou um ciclo de sensação de grande autonomia. Cíntia explicou: "mudou tudo, fiquei mais responsável, mais presente, eu era muito danada, trabalhava, era independente, saía a hora que queria, ninguém mandava em mim, depois fiquei dependente, mais humilde”.

As representações que associam a maternidade à 'perda da autonomia', que imaginavam ter ou que gostariam de ter, pareceram servir para promover a adequação de si ao novo papel a ser desempenhado, o materno. Ou seja, algumas acreditavam que ser mãe é resignar-se a determinadas condições, como a dependência de outrem. 
Nesse sentido, Leocádia disse: "fiquei dando carinho, amor de mãe, dando amor de mãe para ele, não fiquei mais sozinha, porque meu marido ia trabaiá, experimentei o que é ser mãe". Geórgia falou: "tudo mudou, parei de estudá, gostava de festa, não vou mais, não é para qualquer lugar que dá pra $i$, fiquei dependente das pessoas, até i no médico tem que ficá dependendo das pessoas".

Junto com a concepção de que ser mãe é em certa medida depender de alguém, é que, de igual forma, surgiu o entendimento de que ser mãe é equivalente a cuidar. A esse respeito, Mayara falou: “mudou bastante coisa, a responsabilidade que devia ter e não tinha, dá banho, carinho, não queria cuidá dele, eu não entendia o que era ser mãe”.

'Pensar nos filhos' foi uma expressão muito usada para dizer dos cuidados que dedicavam aos filhos. Luiza disse: "mudou muito a minha vida, tudo o que você pensa é em primeiro lugar para o filho, tudo o que eu faço é pensando neles”. Anaclara, por sua vez, falou: “tomei mais responsabilidade, tudo o que eu faço é pensando no meu filho, na minha família”. Márcia, de igual forma, explicou: "antes eu não me preocupava com nada, agora eu tenho que me preocupá, onde estou, fico preocupada, a hora de comprá as coisas, primeiro ela”.

Outro atributo associado ao papel de mãe e citado constantemente pelas adolescentes é de que passaram a ter mais juízo/responsabilidade com a gravidez: Fátima falou: "mudou tudo, tem que tê responsabilidade, não sabia cuidá de casa, tive que aprendê". Denise comentou: "eu amadureci, criei mais juizo, responsabilidade, por que casada, com filhos, esposo, tem fazer de tudo”. Luciane disse: "mudou tudo, tomei mais juizo, tive mais responsabilidade".

Fabrícia, por sua vez, explicou: "mudou tudo, fiquei adulta, antes eu não tinha juízo nenhum, era muito danada, minha mãe que sabe o trabalho que eu dava”. Raquel, do mesmo modo, relacionou a 'tomada de juízo' a certa privação: “eu mudei, não prá pior, meu juízo mudou pra melhor, eu era muito extrovertida, brincalhona, menina, nas minhas idéias pensava muito em ir morá junto com as colegas, pensava só em mim, agora só penso nela”. 
A nova condição pareceu também pautar-se pela busca de certa estabilidade, a começar por fixar residência. A esse respeito, Maria contou: “eu tive que pára morano num lugar só, antes vivia trabalhando em fazenda, tive que tê mais responsabilidade”. De forma idêntica, Lara disse que 'aquietou-se': "mudou muita coisa na vida depois que fiquei mãe, eu não ficava em casa, ficava até um mês fora, saía com as amigas, agora estou ficando em casa, mudou bastante”.

A mudança de comportamentos e da 'cabeça' pareceram alinhar-se na busca da 'estabilidade materna'. Daniela contou: “mudou muita coisa, sei lá, saí não posso mais, tem que levá o nenê quando saio, mudou um pouco a cabeça, o pensamento tá diferente". Nures, aproveitando a ocasião, disse: "muita coisa mudou, parei de brigá com meu marido, aprendi a convivê mais com ele, parei de bebê".

Aliás, a busca da estabilidade pareceu em alguns casos, atingir situações extremas. Judite contou: "depois da gravidez, mudou tudo na minha vida, o que eu fazia, só fazia coisa ruim, nem sei como me aquietei, eu era muito danada, não sei como virei mãe, o meu marido é um pai e mãe prá mim, eu não tenho a cabeça pronta ainda, o que eu faço de errado, ele me corrige”. Mariane, por sua vez, aponta que o filho veio salvá-la das drogas: "o minha filha mudou tudo, acabou toda a bagunça e o sossego também, acho que foi Deus que mandou essa menina, senão eu já tava morta”.

Essa sensação de renascimento proporcionada pela maternidade parece ter ocorrido com várias outras adolescentes. A esse respeito, Vanessa explicou: "meu filho fez eu enxergá melhor as coisas, eu chamava muito a atenção, eu cresci, enxerguei que tenho uma vida pela frente, que eu tenho sonhos e que eu posso buscá”.

Finalmente, 14,3\% das adolescentes referiram que uma das mudanças provocadas pela maternidade foi o abandono dos estudos. Para essas, ter deixado de estudar foi citado como uma perda importante, a tal ponto que Santina a citou como a única mudança decorrente da maternidade. Lamentando, ela disse: "tive que pará de estudá”. 
Com Fernanda aconteceu algo semelhante. Ela contou: "mudou muita coisa, parei de saí, de estudá, depois que engravidei parei de i em muita coisa que eu ia”. Patrícia, por sua vez, lamentou: “mudou, não estudo mais, não saio mais". Laíze, do mesmo modo, falou da nova condição: "parei de bebê, não vou mais em festa, tive que pará de estudá, tudo para trás, me arrependo muito”.

Rafaela explicou o que pretendia antes da maternidade: "um montão de coisas, o estudo, eu pretendia terminar tudo, agora tive que pará, ainda agora com mais dois, fica mais dificil”.

Pelo observado, foram intensas as transformações trazidas pela primeira maternidade, mudanças que parecem colaborar para a precarização das condições de vida, que se solidificaram ao mesmo tempo em que novas maternidades aconteceram. 


\section{8 - DISCUSSÃO E ANÁLISE DOS RESULTADOS}

\section{1 - A Dinâmica Reprodutiva da População Adolescente de}

Rondonópolis-MT e do Brasil e as Maternidades Sucessivas

Os dados do Censo $2000{ }^{58}$ mostraram que no ano 2000, a população de 10 a 19 anos, residentes em Rondonópolis, compunha 21\% da população total, percentual muito próximo à média nacional de adolescentes na população, 20,8\% ${ }^{23}$. Ou seja, embora o acelerado aumento populacional ${ }^{50}$ tenha produzido algumas distorções no crescimento do município, como no ordenamento urbano, na oferta dos serviços de saúde e educação, não produziu efeitos significativos sobre a composição da população adolescente quando comparada ao restante do país.

Consequentemente, não se observou que a dinâmica reprodutiva da população adolescente de Rondonópolis-MT foi influenciada por algum fenômeno populacional particular. Pelo contrário, ela descreveu movimentos muito próximos àqueles observados no restante do Brasil no período 2000/2006, em especial, o decréscimo da proporção de FNV em adolescentes, conforme descrito por vários estudos ${ }^{14,15,23,24,26,27 \mathrm{e} 118 .}$

Ou seja, ocorreu no município, guardadas as devidas proporções, o mesmo que aconteceu com a dinâmica reprodutiva da população brasileira, que a partir do ano 2002, inverteu a tendência de crescimento das maternidades na adolescência, e desde então, vem caindo ano a ano, reduzindo, inclusive, a taxa de fecundidade total ${ }^{14}$.

Quando o país apresentou 21,8\% de FNV em adolescentes de 15 a 19 anos, em 2002, e reduziu para 21,3\%, em 2003, a Região Centro-Oeste acompanhou essa tendência e reduziu, respectivamente, de $23,1 \%$ para $22,3 \%{ }^{24}$ e 23. Nesse aspecto, Rondonópolis-MT, saiu de uma situação de pico, 28,3\%, atingida em 2001 e diminuiu para 26,2\% em 2003, assinalando, também, o início da redução de maternidades em adolescentes. Apesar do percentual ainda ser 
maior que o verificado na região Centro-Oeste, no ano de 2002, era menor que o apurado para o Estado do Mato Grosso, na época, 26,7\% ${ }^{23}$.

Os dados publicados pelo relatório SAÚDE BRASIL $2006^{26}$, registram que, o percentual de FNV em adolescentes de 15 a 19 anos no Brasil, em 2004, caiu para $21,0 \%$, movimento de redução em relação aos anos anteriores que também verificamos em Rondonópolis-MT, que atingiu, no mesmo ano, 23,6\% e, em 2006, caiu ainda mais, para 22,7\%, se aproximando assim, do percentual registrado na região Centro-Oeste em 2003 - último ano com esses dados publicados.

Apesar desse cenário de diminuição das gravidezes e em percentuais diferentes, as proporções de nascidos vivos entre as 'menores de 15 anos', mantiveram-se estáveis nas regiões brasileiras entre os anos 2000 e 2004 VI último ano com esses dados publicados. O maior percentual ocorreu na região Norte, representando $1,4 \%$ dos FNV em 'menores de 15 anos' e o menor percentual, na região Sudeste, $0,6 \%$. A região Centro-oeste manteve-se em 1,0\% 26.

Entretanto, no município de Rondonópolis-MT, o percentual de FNV de adolescentes 'menores de 15 anos', representou no ano 2000, 1,0\% e em 2006, $1,1 \%$ dos nascidos vivos na população geral, percentuais ligeiramente acima da média nacional, 0,9\%, registrado no período 24 e 26 . Em números absolutos, correspondeu a 31 nascidos vivos em 2000 e a 35, em 2006.

Se apresentarmos de outro modo e compararmos esse dado ao total de FNV apenas entre a população adolescente, os FNV na faixa etária 'menores de 15 anos', representou em Rondonópolis-MT, no ano 2000, 3,6\% e, em 2006, aumentou para $4,6 \%$.

Apesar da não diminuição dos percentuais de FNV na faixa etária 'menores de 15 anos', tanto no Brasil ${ }^{24}$ e 26 como em Rondonópolis-MT, quando se considerou a faixa etária ampliada, entre 10 a 19 anos, ainda assim, permaneceu a trajetória de redução do percentual de FNV nessa faixa etária em relação ao total de FNV na população. Em Rondonópolis-MT, o percentual saiu

\footnotetext{
${ }^{\mathrm{VI}}$ Em números absolutos ${ }^{26}$, a quantidade nascidos vivos de adolescentes 'menores de 15 anos' no período 2000/2004, teve queda. Em 2000, chegou-se a 28.973 nascidos vivos e, em 2004, caiu para 26.276. Apesar da redução, não foi suficiente para alterar o percentual da faixa etária.
} 
de um pico de 29,3\%, ocorrido em 2001, caindo para 23,8\%, em 2006. Dito de outra forma, em Rondonópolis-MT, no ano 2000, a razão era, na população adolescente de 10 a 19 anos, de 1 FNV para cada 3,5 FNV no restante da população. Em 2006, a razão foi de 1 para cada 4,1.

Com isso, ao compararmos os percentuais de FNV na faixa etária 'menores de 15 anos' e na faixa etária de 15 a 19 anos, podemos concluir que a redução de 'FNV na população adolescente' incidiu apenas entre as adolescentes de 15 a 19 anos. A conclusão serve para o observado em Rondonópolis-MT, mas parece servir também para o que está ocorrendo no país.

Assim, os dados encontrados no município de 2000 a 2006 confirmam a recente trajetória de redução de maternidades entre adolescentes ocorridas no

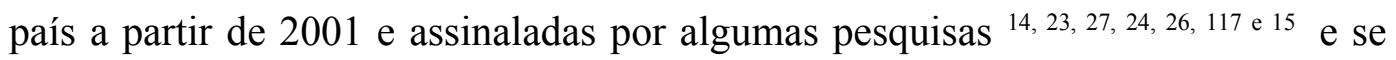
opõem, portanto, aos levantamentos realizados na década de 90 em que se registravam, ano a ano, aumentos da maternidade em adolescentes (FERRAZ e col. ${ }^{43}$, 1998; MELO e col. ${ }^{70}$, 1998; CAMARANO, $1998^{43}$ ).

No que se refere ao percentual de segundo ou mais FNV em adolescentes quando comparado ao total de FNV no restante da população de Rondonópolis-MT, conceituados, outrora, como 'maternidades sucessivas', constatou que foram reduzidas consideravelmente nos últimos anos, caiu de 7,6\%, no ano 2000, para 4,6\%, em 2006.

A partir desses dados apurou-se que as maternidades sucessivas na adolescência diminuíram 37,2\% no período 2000/2006 (sete anos), ou seja, redução média de 5,3\% ao ano. Quando se comparou, no mesmo intervalo, a proporção com que o percentual de FNV de adolescentes com 'maternidades sucessivas' colaboraram para a composição do total de FNV na população adolescente (10 a 19 anos), novamente se apurou considerável redução.

Caiu de 26,8\%, em 2000, para 19,0\%, em 2006, permitindo afirmar que em 2000, a razão fora de 1 adolescente com maternidades sucessivas para cada 3,7 adolescentes na 'primeira maternidade'. Em 2006, a razão foi de 1 para cada 5,2 .

Embora vários pesquisadores ${ }^{34,43,68,107,112}$ tenham relatado percentuais de maternidades sucessivas em adolescentes, não o fizeram em relação aos 
indicadores propiciados pelo SINASC ${ }^{25}$, mas em relação à própria amostra que estudaram, o que inviabilizou comparações com os dados ora apresentados. Entretanto, CHEMELLO ${ }^{17}$ adotou a mesma referência e apurou, em 1999, no município de São Marcos-RS, 5,2\% de adolescentes com "gravidezes subseqüentes", percentual abaixo do encontrado em Rondonópolis no ano 2000 (7,6\%), mas acima do encontrado em 2006 (4,6\%).

Os dados que apontam para a considerável redução das maternidades sucessivas na adolescência no município de Rondonópolis-MT não são condizentes com aqueles encontrados por TAKIUTI ${ }^{117}$. Segundo a pesquisadora, nos anos de 1998 a 2002, no Estado de São Paulo, enquanto, por um lado, se reduzia consideravelmente o percentual da primeira maternidade em adolescentes (10 a 19 anos), por outro, aumentava a proporção de adolescentes com mais de um filho.

Diferentemente desse fenômeno ocorrido no Estado de São Paulo, que pode ter sido uma especificidade ou mesmo, um período de transição, a redução do percentual de 'FNV de adolescentes' em Rondonópolis-MT foi acompanhada de significativa redução do percentual de 'FNV de adolescentes' que deram à luz ao 'segundo ou mais filhos'.

Com isso, reduziram-se concomitantemente as 'primeirasmaternidades' e as 'maternidades sucessivas'. Apenas, ao se decompor a faixa etária de 10 a 19 anos, foi que se constatou que entre as 'primeiras-maternidades' em 'menores de 15 anos' não houve diminuição.

Esses dados refutam a hipótese acima aventada de que a diminuição dos percentuais de gravidezes na adolescência não seria acompanhada da diminuição dos percentuais de 'maternidades sucessivas'. Os dados encontrados em Rondonópolis-MT revelaram certa simetria na redução de ocorrência dos dois fenômenos e reforçam as observações acerca do vigor da trajetória descrita pelos percentuais de 'primeiras maternidades' em menores de 15 anos.

A conclusão óbvia que se espreitou foi a de que a ocorrência de 'primeiras maternidades' em adolescentes 'menores de 15 anos' estaria, então, diretamente relacionada às maternidades sucessivas, sobredeterminando sua 
ocorrência algum tempo depois. Entretanto, devemos deixar essa hipótese explicativa em suspenso, não porque possa ser falsa, mas porque não é o único elemento que contribui para a ocorrência das maternidades sucessivas.

Em termos percentuais, mesmo que todas as adolescentes 'menores de 15 anos' de Rondonópolis-MT, em 2005, tivessem ficado novamente grávidas em 2006, seus novos filhos representariam no máximo, $1,0 \%$ do total de nascidos vivos em relação ao total de nascidos vivos no restante da população. Entretanto, no mesmo ano, os nascidos vivos de adolescentes com maternidades sucessivas representaram, no município, 4,6\%.

Ou seja, as 'primeiras maternidades' em adolescentes 'menores de 15 anos' corresponderiam, em 2006, se todas tivessem ficado grávidas novamente, a apenas $25 \%$ das maternidades sucessivas. Obviamente, que nem todas 'repetem' as maternidades no próximo ano, mas nos anos seguintes, o que acaba distribuindo os percentuais ao longo do tempo, que por outro lado, são compensados com aquelas dos anos anteriores.

Temos, portanto, que embora as 'maternidades sucessivas' possam relacionar-se diretamente com a maternidade em 'menores de 15 anos', englobando-as, é necessário considerar que essa é um fenômeno muito maior, para o qual, a gravidez antes dos 15 anos seria apenas uma variável.

Pareceu, assim, que as 'maternidades sucessivas' dependeram, em sua porção maior, de situações e condições que ocorreram ou tiveram suas conseqüências a partir da primeira gravidez quando essa ocorreu após os 15 anos. Essas circunstâncias corresponderam, pelo que foi demonstrado, a 75\% do número de maternidades sucessivas.

Ao compararmos essas reflexões com os dados apurados em Rondonópolis-MT no período 2000/2006, identificamos que a razão entre 'FNV em menores de 15 anos' e 'FNV em adolescentes com maternidades sucessivas' diminuiu consideravelmente. Em 2000 tínhamos 1 para cada 7,3, em 2006, 1 para cada 4,0 .

Ou seja, se, pelo que já foi apresentado e analisado, concluímos que as 'maternidades em menores de 15 anos' não estão diminuindo, as causas da diminuição de maternidades sucessivas só podem relacionar-se aos motivos 
intrínsecos às adolescentes novamente grávidas que assim ficaram pela primeira vez após os 15 anos. Podemos, também, elucubrar que se os percentuais de 'maternidades sucessivas' continuarem caindo da forma como foi verificado e as 'primeiras maternidades' em 'menores de 15 anos' aumentarem ou permaneceram como estão, em alguns anos podemos ter uma associação direta e exclusiva entre essas categorias.

Essas considerações permitiram concluir que existem variáveis na dinâmica reprodutiva da população adolescente de Rondonópolis-MT que estão contingenciando os nascimentos de filhos vivos na faixa etária de 15 a 19 anos e, conseqüentemente, proporcionando a redução da 'primeira maternidade' e das 'maternidades sucessivas'.

Esse movimento da dinâmica reprodutiva ficou mais bem ilustrado quando se analisou o movimento reprodutivo da população em geral. Notou-se que no período estudado, os nascidos vivos de mães na faixa etária de 20 a 34 anos, representaram do total de nascimentos ocorridos na população do município de Rondonópolis-MT, em 2000, 68,0\%, e em 2006, 70,2\%. Houve, portanto, um aumento da proporção de FNV na faixa etária acima dos 20 anos.

Esse último percentual é relativamente acima do observado pelo relatório SAÚDE BRASIL $2005{ }^{24}$ para o ano 2003 - último ano com dados publicados - como média do país, 68,7\%, mas ligeiramente inferior à média encontrada, no mesmo ano, para a região Centro-oeste, 70,3\%. No relatório SAÚDE BRASIL $2004{ }^{23}$ descrevia-se que a média brasileira de nascidos vivos na faixa etária de 20 a 34 anos, no ano 2001, era de 67,6\% e a média da região Centro-oeste, era de $68,6 \%$.

Constatou-se também, que aumentou o percentual dos nascidos vivos de mães de 35 anos e acima dessa idade, pois, representaram do total de nascimentos no município de Rondonópolis-MT, 3,8\% em 2000 e subiu para 5,8\% em 2006, percentual ainda abaixo do observado para o ano de 2003 por SAÚDE BRASIL $2005^{24}, 9,0 \%$, como média do país, mas próxima da média encontrada para a região Centro-oeste, $6,4 \%$.

Assim a redução de nascidos vivos na faixa etária de 15 a 19 anos e o aumento nas faixas etárias de 20 a 34 anos e 35 e mais anos na população de 
Rondonópolis-MT seguem a mesma tendência apontada pelo cruzamento dos dados apontados por Saúde Brasil (2004) ${ }^{23}$ e Saúde Brasil (2005) ${ }^{24}$ para o país.

Esses documentos indicam que está ocorrendo um fenômeno inverso na dinâmica populacional ao que foi descrito por BERQUÓ e col. ${ }^{13}$ (2003) e outros autores ${ }^{63 \text { e } 114}$ nas décadas de 80 e 90, onde ocorreu a rejuvenescimento da fecundidade, com a antecipação do peso da fecundidade para período reprodutivo anterior aos vinte anos. Sugerem, portanto, a inauguração de um novo período na dinâmica reprodutiva brasileira, caracterizado pela postergação da fecundidade ou retorno aos patamares observados em décadas anteriores.

Ao se considerar os dados da PNAD 2004, interpretados por BERQUÓ e col. ${ }^{14}$ (2006), concluiu-se que esse movimento da dinâmica reprodutiva faz parte de um contexto maior, que é o da redução das taxas de fecundidade total da população brasileira, que está ocorrendo nos últimos anos, em maior proporção, entre as mulheres pobres e menos escolarizadas. Pareceu, portanto, pelo que foi analisado, que a redução de 'primeiras maternidades' e 'maternidades sucessivas' na faixa etária de 15 a 19 anos é uma variável interna desse fenômeno.

Segundo BERQUO e col. ${ }^{16}$ (2005) e BRASIL (2006) ${ }^{27}$ a recente redução da taxa de fecundidade total no Brasil está relacionada ao incremento das campanhas para prevenção das IST e à AIDS, à melhoria das políticas de saúde reprodutiva para adolescentes, ao surgimento da pílula do dia seguinte, à inserção da educação sexual nos programas escolares e à intensa divulgação nos meios de comunicação dos 'efeitos nefastos' da gravidez não planejada na adolescência. 
8.2 - As Maternidades Sucessivas e a Idade da Menarca, da Iniciação Sexual e da Primeira Gravidez.

Para além da discussão puramente demográfica a respeito da correspondência entre 'maternidades antes dos 15 anos' e 'maternidades

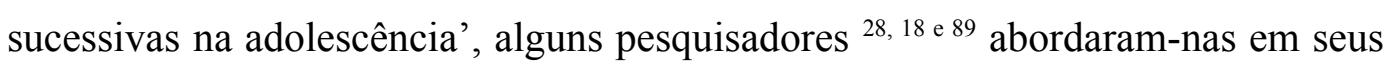
aspectos intrínsecos, como 'gravidez e sua relação com a idade da menarca' e 'gravidez e sua relação com a idade da iniciação sexual.

HEILBORN ${ }^{57}$, a respeito dos critérios etários, critica o que chama de “entronização da categoria idade" como variável de análise, principalmente, se for analisada puramente do ponto de vista etário e desconsiderar as demais dimensões que a ela se juntam.

Há que destacar também, que embora comumente se utilize a expressão 'iniciação sexual' como sinônima de 'primeira relação sexual', na realidade, são eventos que se sucedem ${ }^{28}$. A iniciação não se pauta apenas pela relação sexual em si, mas por uma série de experimentações pré-sexuais que se iniciam antes e produzem aproximações lúdicas e eróticas do próprio corpo e do corpo alheio ${ }^{18 \mathrm{e} 19}$.

Nesse percurso, geralmente ocorre o redimensionamento e "interiorização dos constrangimentos parentais e sociais, em especial os de gênero" ${ }^{19}$ (p.1424) Parece que é nesse contexto que a expressão "eu me perdi”, muito usada pelas adolescentes ao se referirem à iniciação sexual ganha um sentido primoroso, o de que se perdeu em suas descobertas no jogo lúdico-erótico da iniciação, sem deixar, obviamente, de também assinalar, o lado pejorativo da 'perda', de sair de um estado a outro pior, de perder a virgindade, dote não mais recuperado.

Com isso não se descarta que há iniciações sexuais em que as desigualdades de gênero ${ }^{18,19}$ e 57 e outras formas de violência ${ }^{33}$ sobrepujam qualquer percurso de descoberta. Aliás, a esse respeito, os dados que encontramos não revelaram o emprego de violência física nas iniciações sexuais, mas outros tipos de violência, como pressões e coerções, diferentemente, dos 38,8\% de 
adolescentes que fizeram referências à situações em que sofreram violências físicas no transcorrer das parcerias, mas não na iniciação sexual.

A respeito das indicações feitas pelos estudos realizados por CAVASIN e col. ${ }^{33}$ que relacionam a primeira relação sexual decorrentes de situações onde houve o emprego de violência, na faixa etária menores de 14 anos, não encontramos dados que corroboram seus achados nos termos aventados.

Entre as adolescentes com maternidades sucessivas, a primeira relação sexual ocorreu para 49\% delas, antes dos 14 anos. A média de idade da iniciação sexual deu-se aos 14 anos, mesma média encontrada por PERSONA e col. ${ }^{89}$ num grupo de adolescentes com 'repetição de gravidez'.

Entretanto, essa média foi consideravelmente mais baixa, variando de

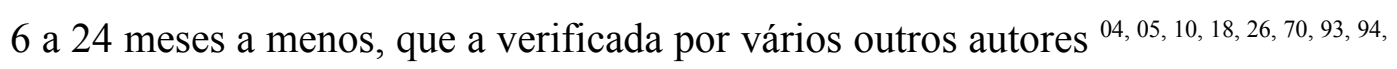
106, e 109 que investigaram a idade de iniciação em diversos grupos de adolescentes. Ou seja, os dados encontrados em Rondonópolis-MT, além de corroborar os estudos, sugerem, em acordo com PERSONA e col. ${ }^{89}$ que a iniciação sexual em torno dos 14 anos esteve relacionada, no grupo estudado, às maternidades sucessivas'.

BORGES ${ }^{18}$ e PERSONA e col. ${ }^{89}$ também relacionam a primeira relação sexual logo após a menarca ao aumento da possibilidade de ocorrência de gravidezes na adolescência. Pelo que encontramos, parece que podemos relacioná-la de igual modo e acrescentar sua relação com as maternidades sucessivas. Entre as participantes, 51,9\% iniciaram a vida sexual antes dos quatorze anos.

Desse total, 2,1\% iniciaram antes dos 12 anos, outras 18,4\%, dos 12 aos 13 anos, 26,5\%, dos 13 aos 14 anos. Ou seja, para a maioria das adolescentes, a iniciação sexual praticamente coincidiu com a menarca, tendo em vista que para $57,2 \%$ das adolescentes estudadas, a menarca ocorreu após a idade de 12 anos. Esses dados se assemelham aos encontrados por SANTINI DE ALMEIDA 108 (2002).

Tendo em vista esses resultados, conclui-se que a iniciação sexual seguida ou não de gravidez 'antes dos 15 anos' pode ter deixado de ser uma tendência, como afirmavam alguns estudos ${ }^{10,22 \text { e } 70}$ na década de 90 e se desponta 
como uma condição generalizada entre as adolescentes das camadas populares, em acordo com o que também BORGES ${ }^{18}$ concluiu. Contudo, é necessário reconhecer que as 'maternidades sucessivas' se apresentaram muito mais como conseqüência da iniciação sexual em torno dos 14 anos', do que o inverso, ou seja, a iniciação nessa idade não é a causa de todas as 'maternidades sucessivas'.

Portanto, é necessário inverter o raciocínio e se perguntar em que aspectos as 'maternidades sucessivas' estão relacionadas com a iniciação sexual ocorrida aos 14 anos? Muitas outras adolescentes iniciaram-se sexualmente aos 14 anos e não ficaram mães aos 15 anos, uma ou mais vezes. Aliás, isso sugere a presença de situações protetoras.

Grosso modo, se não houver mecanismos protetores, as conseqüências diretas do exercício da vida sexual são as gravidezes e a possibilidade de infectarse ou transmitir infecções sexuais. Assim, não é de estranhar que quanto mais cedo a adolescente inicia a vida sexual, mais cedo essas conseqüências podem se apresentar e, talvez, até mais intensamente. Portanto, essa discussão parece contemplar apenas as obviedades do fenômeno.

O que caracteriza esses dados e que é confundido com "precocidade biológica" é o fato de que quanto menor a idade, geralmente, menor é o acesso às informações, às vivências e aos recursos protetores, o que parece aumentar as dificuldades de negociação entre parceiros. Portanto, esses fatos pouco se articulam com a cronobiologia, mas com outras dimensões, como as sociais (por exemplo, contexto de vulnerabilidades ${ }^{8,18 \mathrm{e} 57}$ ), culturais (desigualdades de gênero, entre outras) e subjetivas (sentimento de desenraizamento, baixa estima, etc.). Nesse sentido, os intervalos entre menarca, iniciação sexual e a primeira gravidez pareceu ser um indicativo mais importante para as políticas públicas de atenção aos jovens do que a idade da primeira gravidez.

Por exemplo, as constantes referências das adolescentes ao 'virar moça' e a importância que deram à própria mãe como cuidadora adequada para o momento da menarca, reforçam a indicação de que as mães devem instrumentalizar-se para colaborarem mais efetivamente no desenvolvimento das filhas. É um momento para se estabelecer vínculos de confiança, ocasião em que, as unidades de saúde, a escola, os serviços de atenção social podem se colocar 
como parceiras das meninas-moça. São parcerias a serem firmadas antes mesmo da iniciação sexual.

$\mathrm{Na}$ iniciação sexual, 12,2\% ficaram grávidas. Com um ano após a iniciação, 63,2\% estavam grávidas. Outras 16,3\% levaram mais de 30 meses para ficarem grávidas. Ou seja, para algumas, nada as protegeu, nem mesmo a sorte, que apesar do trocadilho, representa uma das dimensões mais enigmáticas para os trabalhos de promoção e prevenção, como se discutirá à frente no tocante ao uso dos métodos contraceptivos.

Consequentemente, tendo em vista a idade de iniciação e o intervalo até a primeira gravidez, $49 \%$ do grupo de participantes, ficaram grávidas antes dos 15 anos e $22,5 \%$ tiveram a primeira maternidade iniciada entre 15 e 16 anos, $16,3 \%$, entre 16 e 17 anos e, 12,2\%, acima dos 17 anos.

Portanto, 51\% das 'maternidades sucessivas' ocorreram em adolescentes que ficaram grávidas pela primeira vez após os 15 anos, colaborando para que, em média, a idade da primeira gravidez ocorresse aos 15 anos e 2 meses, confirmando, as indicações de vários autores ${ }^{28,18,103 \text { e } 114}$ sobre a idade da primeira gravidez. São consoantes também, aos resultados encontrados por PERSONA e col. ${ }^{89}$ que descreveram que entre as adolescentes com maternidades sucessivas, $72,2 \%$ tiveram a primeira gravidez "em torno dos 15 anos".

Também o intervalo entre o primeiro parto e a nova gravidez mostrouse um indicador importante e revelam falhas estruturais da assistência da saúde. Talvez seja preciso inventar o 'pós-natal' e dotá-lo de significação parecida ao do pré-natal, tanto para puérperas, quanto para os profissionais do setor saúde. Os cuidados de puericultura parecem roubar a cena e enquanto toda a acolhida, nos meses seguintes, se volta ao recém-nascido, se negligencia que a mãe continua tendo vida sexual e deixa, por exemplo, de retornar às consultas pós-parto ${ }^{89}$.

Encontramos em Rondonópolis-MT, que após o primeiro parto, 33,3 \% das adolescentes estavam grávidas pela segunda vez antes de 12 meses, 79,2\% antes de 24 meses e somente 20,8\% levaram mais de dois anos para a nova gravidez. Após o segundo parto, 50\% estavam grávidas pela terceira vez em menos de doze meses e 83,3\% em menos de dois anos. Apenas 16,6\% levaram mais de dois anos para a terceira gravidez. 
Ou seja, parece haver uma intensificação dos ciclos de maternidade após a primeira, que na maioria dos casos, impede que as adolescentes retomem a escolarização, o que definitivamente, parece inseri-las na vida reprodutiva e no 'destino materno e doméstico'. Temos, portanto, que para certa parcela dessas adolescentes, continua faltando no pós-parto, o mesmo que faltava antes. 


\section{3 - As Maternidades Sucessivas e o Grupo Familiar de Origem}

Não foi fácil para a maioria das adolescentes reconstruírem parte de suas histórias de vida na medida em que requeriam fragmentos relacionados ao seu grupo familiar de origem. Aliás, até mesmo a respeito das próprias vivências, muitas vezes, recorriam a outras pessoas da residência para ajudá-las. A impressão geral foi que o passado é uma dimensão da vida que não se registrou ou que não foram integradas às vivências do presente.

Pareceu colaborar para o solapamento da própria história, o 'desenraizamento' que marca a origem e a trajetória de vida dessas adolescentes. Seus antepassados vieram, em sua grande maioria, de outras regiões do país. Ao se estabeleceram, vincularam-se à região, mas não ao lugar. Suas histórias são marcadas por perambulações por todo o Estado e por uma série de interrupções nas atividades que faziam aqui e acolá. A construção de um sentimento de 'pertença' pareceu obnubilada e, aparentemente, a de identidade cultural.

Pareceu contribuir para o fenômeno, a fragmentação do grupo familiar, chamando atenção o fato de que ao entrarem na adolescência, 72,9\% não contavam pelos mais diversos motivos, com a presença paterna, diferentemente, do restante, que foram criadas em ambientes familiares tradicionais. Esses dados confirmam o estudo de PERSONA e col. ${ }^{89}$, quando descreve a ausência do pai por morte ou abandono entre adolescentes com repetição de gravidez.

Foi considerável também, o percentual de adolescentes que foram criadas apenas pelas mães, 37,5\%, percentual maior que o encontrado por BORGES ${ }^{18}$, em que uma em cada quatro adolescentes coabitava apenas com as mães. Sobremaneira, chamou a atenção, o considerável percentual de adolescentes, $31,3 \%$, que foram criadas por terceiros, quer sejam famílias adotivas ou outros parentes.

Numa análise puramente psicológica, a ausência paterna parece relacionar-se à antecipação da busca de um 'objeto amoroso' fora do arranjo familiar e consequentemente, a maternidade parece ser uma forma ou uma tentativa de reconstruir a tríade pai-mãe-filho, ao mesmo tempo em que afirma sua potência feminina ${ }^{39-41}$. 
Pareceu também que a 'busca do pai' se relaciona com o considerável percentual de adolescentes, 59,2\%, que na ocasião da primeira gravidez, mantinham parcerias com homens relativamente mais velhos, acima dos 20 anos, corroborando dados de outro estudo ${ }^{89}$. Curiosamente, durante três visitas, confundimos o parceiro da adolescente, tomando-o como seu pai e indagamos se estava contente com a chegada dos netos. Analisando de outra forma, da condição de filha desamparada, a maternidade coloca a adolescente como provedora, o que parece ser uma espécie de compensação afetiva.

Chamou atenção que 39,5\% tinham representações positivas em relação ao pai, enquanto que as demais se referiram a ele de forma indiferente e negativa, principalmente, quando se referiam àqueles pais que abandonaram a mãe ou que nunca as assumiram. O constante uso do advérbio 'nunca' para se referiram às ações que, julgavam, os pais deveriam ter-lhes provido denotou a intensidade do quanto ansiaram pelo pai.

Entretanto 'ele nunca apareceu', contrariamente, ao ocorrido com as outras $27,1 \%$ de adolescentes, para as quais, o 'pai sempre esteve presente', mesmo quando foi embora. De maneira geral, as experiências das adolescentes em relação ao pai se pautaram por vivências dramáticas, permeadas por histórias de abandono, violência e mortes.

No que se refere às mães, o cenário é menos dramático e os conflitos são de outra natureza, mais ligados à convivência e administração do cotidiano, muito embora, histórias de abandono materno também tenham existido. Quando comparadas aos pais, os percentuais de representações positivas a respeito das mães se invertem. Tinham-nas em 'boa conta', 66,7\% das adolescentes.

Suas histórias revelaram típicas concepções sobre a mãe, como a de que 'mãe é sempre boa', 'mãe é guerreira', mas mostraram também, os consideráveis esforços a que se submeteram muitas de suas mães para criar vários filhos sem o parceiro. Entre suas mães, 69,3\% tiveram pelo menos três filhos.

Considerando a indicação aventada por PERSONA e col. ${ }^{89}$ a respeito de que a história familiar de gravidezes na adolescência se repetiria nas gerações seguintes identificamos que apenas $12,2 \%$ das mães das adolescentes ficaram grávidas antes dos 15 anos, enquanto que entre elas, 49\% assim ficaram. 
Embora algumas mães discordassem dos comportamentos das filhas e tenha tomado atitudes punitivas drásticas como a expulsão de casa e não aceitação do parceiro da filha 'dentro de casa', de maneira geral, a mãe surge como a grande apoiadora das adolescentes, muitas vezes, assumindo por completo a criação dos netos, tarefa exercida também por considerável número de sogras.

Ainda que o modelo de família tenha uma força cultural, subjetiva e social muito grande, a tal ponto que as adolescentes pleiteavam constituir uma, o que se observou e em conformidade com outras pesquisas ${ }^{18 \mathrm{e}} 108$, foi que na origem e criação das adolescentes, os arranjos familiares nucleares não foram predominantes. Apenas $27,1 \%$ assim se caracterizaram. Nesse sentido, vários estudos ${ }^{18,19 \text { e } 39-41}$ apontam que o papel da família é preponderante na forma como os adolescentes constroem e administram a vida sexual. 


\section{4 - As Maternidades Sucessivas e as Parcerias Afetivo-Sexuais}

Diferentemente de pesquisas ${ }^{10,22}$ e 70 que relacionaram a gravidez de adolescentes à antecipação da iniciação sexual e à "atividade sexual pré-marital", sugerindo que 'antes do casamento' as adolescentes teriam vários parceiros, observamos dados que permitiram outro enfoque. A primeira observação referiuse à categoria 'casamento', que parece não ser mais possível insistir em seu uso e para a qual se propôs o uso do referencial 'parceria fixa' e 'parceria eventual'.

Nesse sentido, observamos que apenas $8,2 \%$ das iniciações sexuais ocorreram em circunstâncias de parceria eventual, ou seja, 93,8\% ocorreram em situações de parceria estável, como namoro $(63,3 \%)$, casamento $(16,3 \%)$, amizade $(10,2)$ e familiaridade - primo - $(2 \%)$. Ou seja, do ponto de vista da redução de danos, a estabilidade é um atributo que facilita a construção de acordos e tomadas de decisões, o que pode atenuar as desigualdades de gênero e outras vulnerabilidades.

Aliás, a maioria das adolescentes mostrou-se preocupadas em afirmar que a iniciação sexual ocorreu em contextos de relativa estabilidade, o que pareceu acenar que a existência de vínculo afetivo para a iniciação sexual permanece como um valor, diferentemente do que se observa entre adolescentes do sexo masculino ${ }^{19}$. Esses dados confirmam os estudos de vários pesquisadores 05, 18, 19, 54, 84, 93, 94, 102 e 109, que indicam ser o 'namoro', a situação em que, predominantemente, as iniciações sexuais ocorrem.

Outro dado encontrado, diferentemente do que se alardeia aqui e acolá sobre a 'promíscua' vida sexual das adolescentes, foi que, 67,4\% ficaram grávidas pela primeira vez tendo um único parceiro sexual, 20,4\%, dois e, $12,2 \%$, três. Esses percentuais são semelhantes aos dados encontrados por ABRAMOWAY ${ }^{01} \mathrm{e}$ que indicam que $70 \%$ dos jovens "só tiveram relações sexuais com um parceiro".

Seguindo a mesma lógica, encontramos que quando ocorreu a segunda gravidez, 40,8\% havia tido experiências sexuais apenas com o parceiro da iniciação sexual. Mesmo quando relataram diversas parcerias sexuais ao longo da vida, apenas 5,2\% disseram ter tido mais de dez parceiros. O restante teve dois, 
três parceiros sexuais, salvo uma e outra que tiveram quatro ou cinco parceiros, incluindo o(s) pai(s) dos filhos.

HEILBORN ${ }^{55}$ (2006) a respeito da estabilidade das parcerias formadas por adolescentes encontrou que a maioria das adolescentes que engravidaram $(97,5 \%)$ e dos adolescentes que já haviam engravidado uma companheira $(85,8 \%)$ encontrava-se em contextos de relacionamentos afetivos estáveis. Nesse sentido, surpreende as características dos vínculos afetivos, especialmente a sua perenidade, tão bem expressa pelo 'morar junto'.

'Ir morar junto' pareceu explicar o inexplicável e revelou a intensidade da relação. Moram juntos e, se, possível, casam-se. 'Morar junto' pareceu subverter as categorias de estado civil e como funciona numa outra lógica que não a do casamento, pode começar e terminar a qualquer tempo, entretanto, 'quem desdenha quer comprar'. Apuramos que esses relacionamentos não são assim tão peremptórios. Há muitos compromissos que se alinhavam 'no fio do bigode e não no cartório'.

'Fugir', 'morar junto' e se possível 'casar' é coisa séria por estes rincões. Entretanto, pareceu ser mais sério para as adolescentes do que para seus parceiros. Várias referências deram conta de que elas foram abandonadas logo após o parto, contabilidade machista que avaliou ser desonesto separar-se durante a gestação.

Apesar disso, por ocasião da segunda maternidade, 67,3\% referiu ter marido, $28,7 \%$, ter namorado (14,3\% havia menos de dois meses), e na terceira maternidade, 50\% disseram ser casadas e o restante, namorar (todas há mais de seis meses), ou seja, todas em parcerias fixas. Na primeira maternidade, apenas $18,2 \%$ estavam em parceria fixa a menos de dois meses.

Esses dados revelaram que embora tenham ocorrido separações, a maioria das parcerias foi caracterizada por certa estabilidade e as poucas que não eram assim antes, tenderam a ser, após a gravidez e, mesmo, após uma separação. As freqüentes referências das adolescentes às radicais transformações ocorridas com a primeira gravidez, de que 'mudou tudo', de que passaram a 'pensar nos filhos', de que ficaram 'mais responsáveis', de que abriram mão da 'liberdade 
adolescente' pareceram ilustrar bem o tamanho do esforço despendido na busca dessa estabilidade.

Assim, "a maternidade foi um elemento reorganizador da vida e não somente um fenômeno desestruturador" 27 e 55 . Pareceu-nos, que em parte, a organização da vida das adolescentes se deu em torno do ideal materno que possuíam. Nesse sentido, 'ser mãe’ e ‘morar junto' é a dura concretização das 'brincadeiras de bonecas' e de 'casinha', em que a mãe tem uma identidade claramente definida e "associada à função de cuidadora" ${ }^{108}$.

Por outro lado, surge uma nova e inquietante observação. A reorganização da vida e estabilidade que tanto buscam 'morando junto' e se fidelizando a um parceiro as tornam dependentes deles. Ou seja, não foram elas que 'seguraram os maridos', foram presas por eles, tornaram-se placidamente dependentes de seus parceiros, como também foi observado por PIROTTA e col. ${ }^{94}$.

Observou-se também que aquelas que não estavam submetidas aos parceiros tiveram que permanecer abrigadas junto às famílias de origem, quando essas se dispuseram a apoiá-las. Aliás, uma das preocupações da segunda e da terceira maternidade referiu-se ao medo dos familiares não as aceitarem 'novamente grávidas'. Esse dado corroborou a indicação feita por BRANDÃO ${ }^{19}$, HEILBORN ${ }^{55}$ e PIROTTA e col. ${ }^{94}$ acerca da maior dependência das jovens mães de seus familiares.

O fato de que por si própria nenhuma adolescente-mãe tinha renda e a observação dos rendimentos mensais de seus provedores e mesmo do total da renda das pessoas com as quais coabitavam, permitiu concluir que dependiam de rendas irrisórias, o que pareceu aumentar-lhes a vulnerabilidade e o estado de dependência. Entre seus parceiros, 55,1\% ganhavam menos de um salário mínimo.

Frente à nova gravidez, outra preocupação apresentada pelas adolescentes que estavam em parceria fixa, pautou-se pela análise que fizeram das condições financeiras do parceiro, pois muitos estavam desempregados ou sem receber salário ou ganhando pouco ou sem garantias de trabalho. Vale destacar, que muitos parceiros também tiveram a mesma preocupação ao saberem da 
gravidez e se mostraram muito mais preocupados quando se tratava da segunda ou terceira maternidade.

Nem mesmo quando se considerou os rendimentos do conjunto das pessoas com as quais coabitavam e da qual poderiam se beneficiar, a renda subiu. Nesses grupos, em 42,9\% das situações, eles tinham rendas menores que um salário. Ou seja, financeiramente, não fazia muita diferença depender do parceiro ou do grupo de pessoas com as quais coabitava que, geralmente, era mantido pela mãe.

Compreende-se agora porque, 'barrigudas' e 'com filhos no colo', ficam meses a fio esperando o parceiro voltar das empreitas que fazem nos currais do pantanal, nas plantações do cerrado ou nos desmatamentos do norte ou então, que simplesmente, somem. Outra das preocupações das adolescentes, por ocasião da nova gravidez, foi o medo de ser abandonada pelo parceiro. O medo tinha lá suas razões de ser, $12,2 \%$ foi abandonada na primeira gravidez, 18,4\% na segunda e $16,6 \%$ na terceira.

Bem ou mal, morando juntos ou separados, elas dependiam dos parceiros, o que trouxe para muitas, sentimentos de muita impotência frente à própria condição e de não saber o que fazer com o novo filho. Conclui-se que a dependência dos parceiros não foi apenas afetiva, mas, principalmente, financeira, situações propícias para que as desigualdades de gênero se tornem ainda maiores.

Contudo, esse é um olhar externo. Há muitos arranjos protetores na comunidade e que passam despercebidos aos olhares estrangeiros. Percebemos que há certa rede de solidariedade cotidiana que permite a continuidade da vida, principalmente, na proteção das grávidas, como a troca de favores, o empréstimo de comida e pequenos bens, 'o gato na água e na luz', as cestas básicas de entidades beneficentes, a ajuda das igrejas, entre tantos outros artifícios de sobrevivência.

Mas o que se expôs acima caracteriza um dos cenários, o das 'descontentes'. De maneira diferente, o outro cenário pautou-se por certa naturalidade da adolescente-mãe no trato da forma como as maternidades foram se sucedendo em sua vida. Pareceu-nos que esse grupo é, basicamente, composto pelos $28,6 \%$ de adolescentes que ficaram satisfeitas com a segunda maternidade. 
A criação de um ou vários filhos não lhes pareceu romper ordem alguma. Pareceu tratar-se de um grupo familiar típico, papai-mamãe-filhos, com papéis e valores bem delimitados e que, aparentemente, em nada difere dos modelos de família idealizados e veiculados por uma ou outra instituição, não fosse a pouca idade e o baixo poder aquisitivo. 


\section{5 - Maternidades Sucessivas e o Uso dos Métodos}

\section{Contraceptivos}

Bajos, citado por BRANDÂO ${ }^{19}$ (2006) diz que a adoção da "norma contraceptiva" envolve alguns aspectos conflituosos nas sociedades modernas, como, por exemplo, a medicalização da sexualidade, que finda por sugerir determinados padrões reprodutivos, geralmente, prescrições dirigidas às mulheres. Entre as adolescentes estudadas, a adesão ao uso dos meios protetores que evitariam tanto à gravidez quanto às infecções sexuais, mostrou-se controversa e quatro dimensões pareceram revelar certo conflito entre 'usá-los' e 'não usá-los':

I - o 'desconhecimento': Observou-se que muitas adolescentes apesar de conhecerem os contraceptivos não haviam se apropriado desse conhecimento como um recurso para o benefício próprio. Houve também, aquelas que demonstraram saber pouco ou nada sobre eles, e certamente, uma parcela delas, se apropriaria desses recursos se tivessem tido a oportunidade de os conhecerem efetivamente. Entre as adolescentes que referiram nada saber sobre os contraceptivos antes da gravidez, observamos que tinham origem rural e esse fato, numa região geograficamente imensa e despovoada, é praticamente uma situação de isolamento geográfico.

Isso pareceu ter privado essas adolescentes do acesso à escolaridade e à saúde, mas privou-as, principalmente, do contato com outras adolescentes e mulheres, com os 'pares', com quem mais aprenderiam ${ }^{18,62,76,104 \mathrm{e} 124}$. Um exemplo desse tipo de aprendizado é o conhecimento sobre os métodos abortivos caseiros que se aprende 'à boca pequena' no cotidiano e conforme a necessidade, diferentemente dos métodos contraceptivos que têm o médico e as unidades de saúde como mediadores.

Pareceu-nos, portanto, que conhecer o método contraceptivo não se refere apenas ao domínio formal das técnicas de uso, mas passa pela integração das informações às próprias vivências, de maneira que sejam superados os tabus, as crenças, medos e fantasias em torno do uso desses insumos e ação deles no 
corpo. O uso inadequado, também encontrado por outros pesquisadores ${ }^{128,77}$, os efeitos colaterais, os esquecimentos e as formas mágicas de uso, soaram como diversas metáforas a revelarem como a relação com os contraceptivos foi tensa e o quanto que a falta de 'informação significada' é um grande impedimento para a adoção de algum método e uso correto.

Justificando essa conclusão, foram comuns as referências ao 'coito interrompido' e ao uso da 'tabelinha', tentativas contraceptivas, aparentemente, incorporadas à dinâmica da vida sexual, que apesar de não funcionarem, são formas que adquiriram algum sentido nas vivências sexuais.

Ter encontrado adolescentes que referiram nada saber sobre os contraceptivos expôs uma face do sertão brasileiro. Muitas adolescentes não sabem nada ou sabem muito pouco sobre contraceptivos. Em parte, pelo isolamento geográfico em que algumas foram criadas, e noutra, porque nem deu tempo de aprender e já estavam grávidas.

Isso é dissonante aos dados encontrados por DADOORIAN 41 MORELL $^{75}$, SCHOR ${ }^{106}$, que revelam grande conhecimento sobre os métodos contraceptivos pelos adolescentes. Entretanto, não destoa de YASAKI ${ }^{128} \mathrm{e}$ BORGES ${ }^{18}$ quando apresentam dados que indicam que apesar do crescimento do conhecimento sobre contraceptivos, seu uso pelas adolescentes não é equivalente ao grau de conhecimento que deles se têm.

II - o 'correr riscos': provavelmente, essa é a dimensão mais desafiadora que se coloca aos trabalhos de promoção e de prevenção de qualquer situação e deve ter lá suas significações para a vida. Em parte, 'correr riscos' remete à condição demasiadamente humana da vida irracional, ainda mais quando se trata da sexualidade.

Se ela fosse passível de racionalizações, os planejamentos seriam perfeitos e, no máximo, as gravidezes seriam 'não planejadas'. Não é de estranhar porque frente à possibilidade de 'sempre haver descuido', a abstinência sexual e as medidas radicais, como a esterilização, acenem como saídas plausíveis a alguns setores da sociedade. No caso da esterilização feminina, não fossem as medidas legais, milhares de mulheres brasileiras estariam esterilizadas aos 25 anos. 
CABRAL ${ }^{28}$ descreve dados em que, na cronologia dos acontecimentos, o comportamento contraceptivo é sempre posterior ao início do relacionamento do relacionamento sexual, ou seja, curiosamente, primeiro se corre os riscos. Talvez seja esse o preço do aprendizado. Parafraseando o poeta, 'correr riscos é preciso'.

Em outra parte, 'correr riscos' parece ter o sentido de "dar cumplicidade à relação", conforme destaca BRANDÃO ${ }^{19}$ e colaborar para o 'estabelecimento de contratos', tal como pareceu ser, o 'morar junto', que se caracterizou pelo cumprimento de uma 'combinação' frente ao risco corrido e que se concretizou.

Talvez isto explique, também, a indignação entre as adolescentes que tiveram parceiros que não assumiram seus filhos: "ele não foi homem" disseram. Aliás, a mesma designação usada, por algumas, ao se referirem aos próprios pais que não as assumiram junto às suas mães. Ou seja, havia um 'pacto de riscos'.

III - as 'dificuldades de acesso': Algumas adolescentes descreveram situações que permitiram perceber que o acesso aos contraceptivos foi impedido de várias formas: Por um lado, os profissionais de saúde, incluindo os atendentes, geralmente, não concebem que as adolescentes possam exercer a vida sexual e isso, interfere na forma como acolhem as adolescentes quando o motivo é de natureza sexual-reprodutiva. Por outro, a necessidade de cadastro, de apresentação de documentos, de agendamento de consultas e até mesmo, exigência da presença de algum responsável são barreiras comuns criadas por unidades de saúde.

Sobre o 'portar documentos', observamos que muitas adolescentes não tinham documentos relativamente simples, como a "carteira de identidade", 'CPF', ou Carteira de Trabalho. Algumas nem o 'registro' possuíam. Ou seja, numa interpretação grosseira, não estão inscritas no mundo do trabalho, do consumo, nem das identidades. Apenas nasceram, protótipos de cidadãs.

As barreiras foram citadas pelas participantes como impedimentos para que tivessem acesso aos insumos de proteção, muito mais até, que a falta dos contraceptivos na unidade de saúde. Aliás, geralmente, os preservativos são distribuídos nas farmácias das unidades de saúde, lugares, muitas vezes, 
localizados junto da sala de espera e sem privacidade alguma, o que certamente, inibe a sua retirada.

De igual modo, pareceram dificultar o acesso, os significados revelados por 'solicitar contraceptivos'. Talvez seja o primeiro momento de 'exposição pública' do 'querer exercer' a vida sexual ou do próprio exercício dela e isto não é tarefa fácil. Há que considerar que é um momento muito solitário, principalmente, para as meninas, para as quais a iniciação sexual e o exercício da sexualidade na adolescência são vistos pejorativamente, diferentemente, do que ocorre com os meninos, para os quais a 'precocidade' e a iniciação sexual é valorizada ${ }^{106,18}$.

Por outro lado, a entrega qualificada de contraceptivos é baseada apenas na relação médico-paciente e quando envolve prescrição de métodos anticoncepcionais. Não foi verificada nas unidades de saúde visitadas que, por exemplo, a entrega de preservativos tenha um caráter mais receptivo, afinal, esse poderia ser um meio de acolhimento, de orientação e de avaliação de vulnerabilidade.

Também os agentes comunitários de saúde, contrariamente, ao que deviam representar, foram vistos com certa desconfiança pelas adolescentes quando se tratou de falar da sexualidade antes da gravidez. Cerca de 30\% das adolescentes referiram não "se abrir" com as agentes de saúde porque poderiam contar para as pessoas ou familiares sobre suas atitudes.

No que se refere ao acesso aos contraceptivos no pós-parto, dois aspectos parecem atrapalhá-lo. O primeiro relaciona-se ao fato de que no prénatal, o objetivo das unidades de saúde é a gestante, enquanto que no pós-parto, deslocam-se as atenções para o bebê. Obviamente que há consultas de retorno no pós-parto e orientações diversas às mães, mas ainda assim a atenção às parturientes nos meses que sucedem o parto é menos intensa. No entanto, essas 'mulheres-mães' continuam correndo riscos, por exemplo, ao HIV, podendo, até mesmo, infectarem-se e infectar o bebê por meio da amamentação meses após o parto. BORGES ${ }^{18}$ sugere que nesse momento, as unidades de saúde podiam investir não apenas na dupla mãe-filho, mas incluir os outros membros adolescentes da família. 
O segundo aspecto parece referir-se às crenças dos profissionais de saúde sobre o exercício da sexualidade durante a gravidez e que são estendidas ao pós-parto. De modo geral, parece acreditar-se que mulher grávida e no pós-parto não tem vida sexual. A própria “quarentena" e o período de amamentação pareceram encarnar por muito tempo as crenças de que as mulheres 'viravam santas' nesse período.

As maternidades sucessivas ilustram bem o quanto que as estratégias de atenção às mulheres nesse período são falhas. Elas continuam com vida sexual e correndo os mesmos riscos, apesar da crença dos profissionais de saúde de que a primeira gravidez 'serviu de lição e não vão ficar grávida novamente'.

Entre as participantes, 6,2\% ficaram grávidas novamente antes de o recém-nascido completar cinco meses de idade, ou seja, provavelmente no primeiro período fértil pós-parto. Outras $12,5 \%$ estavam grávidas outra vez antes de o bebê anterior completar oito meses. Várias relataram que tiveram que interromper a amamentação porque se descobriram grávidas novamente, sem nem mesmo terem menstruado no pós-parto.

Provavelmente, os programas de planejamento familiar devem englobar esses aspectos em suas diretrizes e se uma delas se baseia no uso de anticoncepcionais, muita atenção ter-se-á que ser voltada para o pós-parto. Duas situações se apresentaram na análise do uso de contraceptivos entre um parto e a nova gravidez e servem para a reflexão sobre a qualidade da atenção nesse período e que na verdade, apenas reiteram o ocorrido antes da primeira gravidez: a qualidade da prescrição e o uso incorreto dos anticoncepcionais.

Há algo a ser mais bem estudado frente a tantas queixas dos efeitos colaterais dos anticoncepcionais e mesmo sobre as prescrições. Muitas mães adolescentes referiram fazer uso correto do anticoncepcional no pós-parto e ainda assim ficaram grávidas, diferentemente de uma porção que referiam usar, mas se esqueciam, abandonavam o uso, entre outras atitudes. Aliás, pareceu-nos que o uso incorreto está relacionado com a forma como se prescreveu.

Os dados que encontramos são congruentes aos apontado por PERSONA e $\operatorname{col}^{89}$ que apontam a baixa adesão ao uso de preservativos e o não retorno à consulta médica no pós-parto como um dos aspectos que favorecem a 
ocorrência das maternidades sucessivas na adolescência. De igual modo, os dados confirmam as indicações feitas por NELSON ${ }^{77}$, quando aborda o uso inadequado de anticonceptivos por adolescentes com vários filhos.

Contudo, os dados não coadunam com os expostos por KERSHAW ${ }^{61}$ e STEVENS-SIMON ${ }^{114}$, que indicam a baixa adesão das adolescentes aos anticoncepcionais no pós-parto e que isso facilitaria a repetição da gravidez. A esse respeito encontramos que $85,7 \%$ das adolescentes afirmaram ter usado contraceptivos entre o primeiro parto e a segunda gravidez, das quais, $81 \%$ referiram ter usado pílula.

Entre o segundo parto e a terceira gravidez, 83,3\% referiu ter usado contraceptivos, das quais, $80 \%$ disseram ter usado pílula, diferentemente do dado observado por TAKIUT ${ }^{117}$ que encontrou, entre as adolescentes que, reincidiram na gravidez, apenas $35 \%$ de meninas que já haviam feito uso de contraceptivos.

Certamente, o uso inadequado ou intermitente é que está justificando o fato de terem ficado grávidas novamente, mesmo tendo referido o uso de anticoncepcionais. Portanto, se o objetivo das políticas públicas for o de prevenir gravidezes na adolescência, melhor que sejam, conforme sugere RIGSBY ${ }^{103}$, com anticoncepção eficaz e com uso adequado.

Entretanto, esse posicionamento parece restringir a questão a um problema médico-paciente e, pelo analisado, não se trata de tamanha simplificação.

IV- 'querer ficar grávida': essa dimensão do 'não uso dos contraceptivos' pareceu afrontar a racionalidade de nossos tempos: 'como pode uma menina querer ser mãe? De certa forma, as adolescentes ao desejarem a gravidez e, em decorrência, não adotarem nenhum tipo de contraceptivo 'resolveram' vários conflitos: não precisaram conhecer a contracepção e negociála com o parceiro, nem precisaram permanecer sem o exercício da sexualidade. Assim, parece terem resolvido de igual forma, a ambigüidade entre querer 'ser mãe' e 'não querer'. Portanto, a decisão 'quero ser mãe' fez um atalho nos conflitos e os deu por resolvidos, diferentemente daquela adolescente que vive a 'correr riscos', que parece, permanece numa situação de indecisão. 
Mas há outro aspecto a ser analisado. Nesse a contratualidade com o parceiro não está no 'correr riscos', mas na solução final, que já não acontece no nível individual ou da parceria, mas na busca de alguma "mobilidade social" representada pela maternidade ${ }^{84}$. Nessa linha de raciocínio, a consecução da maternidade pretende atender aos apelos sociais. CARVALHO ${ }^{30}$, a esse respeito, conclui que o corpo é um lugar de resistência frente às situações de marginalização e que as adolescentes grávidas não representam a gravidez como um problema. Ao contrário, se sentem valorizadas socialmente sendo mães.

Apesar da interviniência dessas dimensões em maior ou menor intensidade, $62 \%$ das participantes informaram que usaram preservativos na primeira relação, dado muito próximo ao apontado por BORGES ${ }^{18} \mathrm{e}$ HEILBORN $^{55}$, que encontraram, respectivamente, $68,3 \%$ e $70 \%$ de referências de uso de algum método contraceptivos na primeira relação sexual e muito acima do encontrado por BRASIL ${ }^{27}$, em que apenas $35,1 \%$ das adolescentes referiram ter usado preservativos nas relações sexuais já ocorridas. Entretanto, as participantes referiram não persistir no uso ou usavam eventualmente.

Observamos que a diminuição e mesmo a interrupção do uso dos preservativos pelas adolescentes ocorreu na medida em que elas se sentiam mais confiantes com os parceiros, fato observado também por outros pesquisadores ${ }^{03,18}$, 27 e 89 . Isso parece justificar o fato de que no período compreendido entre seis e doze meses após a iniciação sexual tenha ocorrido o maior percentual de gravidezes, $30,6 \%$.

Curiosamente, entre aquelas que buscaram algum outro método contraceptivo, houve um aumento considerável no uso de anticoncepcionais ("pílulas") à medida que aumentou o tempo de relacionamento, fenômeno também verificado por PIROTTA ${ }^{93}$ entre jovens universitários. Encontramos que ao se iniciarem sexualmente, apenas 10,2\% usavam "pílulas", mas quando ficaram grávidas pela primeira vez, $46,2 \%$ já tinha usado. Esse dado revelou que a preocupação com o risco de infecções sexuais é secundária à preocupação com a gravidez. Talvez essa informação ajude a compreender a feminilização da epidemia da AIDS. 
Todas essas dimensões elencadas parecem confluir para a análise proposta por BRANDÃO ${ }^{19}$ acerca do uso de contraceptivos. A pesquisadora diz que existem muitos aspectos nas trajetórias femininas em relação à gestão e uso dos contraceptivos que podem configurar "momentos de vulnerabilidades".

A adesão aos contraceptivos contém vários aspectos a serem analisados: a "relação médico-paciente que condiciona a prescrição e uso do método"; a "compatibilidade do método indicado com o contexto da vida afetivo sexual feminino"; as "representações sociais sobre a sexualidade"; a "vulnerabilidade à dominação masculina" e a "ambivalência do desejo de ter filhos" ${ }^{19}$ (p.1424).

Certamente, esses aspectos estão influenciando tanto a adesão do uso correto dos contraceptivos quanto o freqüente uso inadequado e parecem ser variáveis importantes a serem consideradas pelos programas de planejamento familiar, até mesmo, porque se propõem a distribuir gratuitamente esses insumos. Pelo que vimos o acesso aos contraceptivos é uma das partes e tão importante quanto às demais, mas não é a única a ser considerada.

Essas considerações e as trazidas por BRANDÃO ${ }^{19}$ fazem refletir também sobre o quanto é difícil realizar planejamentos justamente num aspecto da vida que está sujeito aos diversos desatinos humanos, às desigualdades entre gêneros ${ }^{57} \mathrm{e}$ à uma margem de tolerância muito justa. Uma pequena falha pode romper com uma série de custosos planejamentos. O uso correto de contraceptivos é uma prática que envolve o cuidado de si, dimensão que não se aprende só ou apenas nos bancos escolares, é preciso do outro "no jogo que se instala entre parceiros" ${ }^{19}$, tarefa de uma vida inteira. 


\section{6 - As Tentativas de Provocar o Aborto}

Um dado identificado nas práticas reprodutivas das adolescentes estudadas e que parece relacionar-se com a redução de gravidezes na adolescência e maternidades sucessivas são os indícios de que a prática do aborto é mais comum do que se imagina. Observamos que as tentativas de provocar o aborto estão naturalizadas nos contextos de vida de várias adolescentes e parecem fazer parte da cultura reprodutiva regional, senão brasileira, conforme apontam outros pesquisadores ${ }^{01,45 e 93}$.

Entre as participantes, $24,5 \%$ tiveram intenção de abortar na primeira gravidez, na segunda, $28,6 \%$ e, na terceira, $33,3 \%$. Entretanto, enquanto essas tiveram a intenção e não chegaram a concretizar por diversos motivos, provavelmente, muitas adolescentes conseguiram levar o intento até o fim e, por isso, não apareceram nesse levantamento. Bastou perguntar às participantes se conheciam alguém que tivessem feito aborto, que, espontaneamente, citavam uma ou mais conhecidas.

ABRAMOWAY ${ }^{01}$ (2004) cita que o percentual encontrado de moças e rapazes que referiram ter a vivência ou familiaridade com o aborto, variou "de 7,6\% em Manaus-AM a 2,4\% em São Paulo-SP”. De igual forma, FONSECA ${ }^{45}$ (1998), em estudo realizado com mulheres com aborto incompleto, encontrou $29,7 \%$ de mulheres cuja idade estava entre 15 e 19 anos.

Conforme relata REDE FEMINISTA DE SAÚDE ${ }^{97}$, tem crescido os procedimentos de saúde no SUS para cuidar de conseqüências dos abortos e das tentativas de provocar o aborto, principalmente, entre mulheres das camadas populares. Entretanto, os 'procedimentos do SUS' no trato das conseqüências das tentativas de aborto e abortamentos são praticamente os únicos indicadores da extensão do fenômeno. Está em aberto, a construção de indicadores ou estimativas mais precisos sobre o real número de abortos provocados.

Parece contribuir para essa finalidade, o dado encontrado em Rondonópolis-MT, já que as tentativas de provocar o aborto ora descritas, não entrariam nas estatísticas dos 'agravos por abortamento'. Contudo, ainda assim, não revelam efetivamente quantas adolescentes provocaram aborto ou tentaram 
fazê-lo e não tiveram complicações, sugerindo, portanto, maiores percentuais de abortos provocados que os identificados $45,97 \mathrm{e} 93$.

As falas das adolescentes denotaram uma considerável facilidade de acesso aos abortivos, quer sejam, os 'chás', 'garrafadas', 'raizadas', com exceção dos 'remédios do Paraguai', que custam caro. Por outro lado, o medo das conseqüências, do insucesso da tentativa de provocar o aborto e o não consenso com o parceiro ou familiares e/ou conhecidos, pareceram cercear as tentativas de provocar o aborto, muito mais, mesmo, que as questões ético-morais-religiosas e legais presentes em torno da questão.

Aliás, aquelas que falaram sobre as tentativas de provocar aborto, sempre incluíram outra pessoa que as incentivaram e ajudaram na tentativa ou que as desmobilizaram do fito - parceiros, amigas, tias, irmãs, primas, sogra, avó, entre outros. Contudo, o dado encontrado é constituído, em parte, por reais planos e/ou tentativas de provocar abortos, mas em outra, refere-se muito mais a uma dimensão fantasiosa, em que o aborto se apresenta como um desfecho possível à ambivalência entre ser mãe e não ser.

Mas nos pareceu que esse conflito não é puramente psíquico, ele dialoga com as condições de vida, tanto que, as tentativas de aborto se multiplicaram na segunda e na terceira gravidez e pareceram ser desencadeadas após as percepções do quão difícil seria a criação do segundo e/ou terceiro fillho frente às condições sócio-econômicas em que viviam. 


\section{7 - O (in) Desejo pela Maternidade}

Os critérios demográficos e etários mostraram-se razoáveis como índices 'analisadores' das articulações presentes nas maternidades sucessivas, entretanto, não pareceram tão importantes quanto à consideração do desejo das adolescentes pela maternidade. Entre elas, $47 \%$ manifestaram ter desejado a primeira maternidade.

Vários temas de natureza subjetiva foram enfocados pelas adolescentes e parecem ter em comum, a idéia de que a maternidade era uma condição bem quista e desejada. Ela soou, entre tantas coisas, como oportunidade de 'segurar o homem', 'agradar o marido', 'conquista pessoal', 'evitar a solidão', 'nova responsabilidade' e 'satisfazer a vontade de ser mãe'. Talvez isto ajude a justificar porque $63,2 \%$ ficaram grávidas nos primeiros doze meses após a iniciação sexual.

A primeira maternidade mostrou-se muito convidativa às adolescentes e a sua concretização pareceu contemplar uma série de perspectivas que vinham se alinhavando ao longo de suas vidas: a menarca as tornou "moças", a primeira relação, "mulheres" e a gravidez, "mães". Pareceu, portanto, seguir certa lógica entre acontecimentos, descobertas e significações.

Definitivamente, esses eventos as posicionaram no reino da feminilidade, no qual, a potência feminina se revelou sem pairar dúvidas. Assim ao final do percurso, a maternidade pareceu ter o caráter demarcador, não apenas entre o mundo infantil e adulto, mas também entre o universo feminino e o masculino, principalmente, porque o papel social feminino na contemporaneidade ainda está fortemente vinculado à maternidade ${ }^{39-41 \mathrm{e} 47}$.

Outras significações e gratificações pareceram se associar à perspectiva trazida pela primeira maternidade, especialmente, quando se considerou que as participantes pertenciam aos segmentos populacionais mais pobres. Foi observado que essa população possui valores de vida que se organizavam em torno do presente, diferentes aos de outros segmentos que vislumbram objetivos menos imediatos e que requerem certa mediação temporal entre 'desejos' e 'satisfações', tal como é a promessa feita pela escolarização e profissionalização. 
Ou seja, o apelo liberalista que a modernidade traz, apregoando o tempo todo que o indivíduo deve fazer escolhas entre cumprir o desejo ou postergá-lo, em nome de um benefício maior, pareceu não ter seqüestrado essas adolescentes antes da primeira gravidez. Afinal, nos contextos de maior pobreza, o próprio instrumental de produção e domesticação de desejos, parece não conseguir chegar com toda sua força ou, ao menos, não conseguiu produzir subjetivações iguais às que promove em outras camadas sociais.

A esse respeito, convém perguntar: Que sonhos razoáveis a escola têm prometido às adolescentes pobres ou lhes permitido sonhar? Que perspectivas o mercado de trabalho lhes tem apresentado, que não a expropriação de si e o consumo? "Qual a diferença entre cuidar do filho da patroa e do meu?" Assim, a ausência de horizontes, que na verdade são valores externos a elas, pareceu fazer com que essas adolescentes entretecem consigo mesmas, com seus próprios recursos e desejos. Nesse sentido, a maternidade foi um sonho possível, talvez, o único.

PIROTTA e col. ${ }^{93}$ dizem que a postergação de uniões conjugais, construção de famílias menores, adesão aos métodos contraceptivos e planejamento das gestações são procedimentos adotados por jovens que possuem maior escolaridade. Ou seja, invertendo o raciocínio, são jovens que tomaram como valores, a escolarização e a inserção no mercado de trabalho. A questão que se coloca, então, é: quais são os valores das camadas populares e como que a escolarização pode contribuir com eles, sem precisar tipificá-los como problemas ou crimes.

Pareceu-nos, portanto, que a maternidade, nos contextos de grande pobreza, surge como uma possibilidade de uma produção própria e original. Ser “alguém na vida" ${ }^{84}$ é cativante frente à massificação sofrida. 'Ter um filho', ‘ter um parceiro', 'ter uma casa', 'ter obrigações', ter algo que lhe é próprio num mundo de 'im-propriedades' são dimensões que produzem diferenças e parecem dar sentido para a vida.

Associa-se a isto, a forte valoração social atribuída à maternidade, que acaba sendo tomada como uma estratégia de reconhecimento e ascensão entre 
seus pares, familiares e sociedade e que pode produzir alguma mobilidade social, tal como apontado por CARVALHO ${ }^{30}$ e PANTOJA ${ }^{84}$.

Também pareceu fazer parte dessa complexa teia de motivações para desejar a maternidade, um cenário de considerável carência afetiva. As histórias das adolescentes a todo o tempo foram entrecortadas por relatos de situações de abandono e privações, impostos ora pelo Estado, ora pelo grupo familiar, que, muitas vezes, se fragmentou em algum momento de sua história ou nem mesmo nunca se constituiu. Diz DADOORIAN ${ }^{41}$ que "a vivência de situações de carência afetiva e relacional com a família pode também provocar o desejo na adolescente de ter um filho, em que esse aparece como o objeto privilegiado capaz de reparar esta carência" (p. 90).

Nesse sentido, há um fenômeno psíquico intrigante. Parece haver um deslocamento para o filho ou para a idéia de tê-lo, de que ela, a adolescente-mãe, não o privará daquilo que julga ou de fato foi privada. Isto pareceu ser uma forma de reconstruir as próprias vivências infantis a partir do filho. Não é de estranhar, portanto, o simbolismo presente na fala de uma delas quando disse que "era uma criança cuidando de outra criança", ou seja, cuidava dela mesma.

Assim, a maternidade para a grande maioria de adolescentes não foi uma surpresa abominada. Diferentemente do que, comumente, se diz, observamos que a primeira gravidez foi vivenciada com expectativas positivas e com uma série de modificações no cotidiano das adolescentes, geralmente, realizações construtivas, derivadas de certos projetos de vida. Com isso, não se está negando que, por exemplo, entre aquelas que objetivaram provocar aborto, as vivências desestruturantes ocorreram.

Temos, então, que o contexto subjetivo de ocorrência da primeira maternidade, mesmo quando não planejada, mostrou-se acolhedor e em sintonia com as demandas individuais frente às necessidades do meio. Isto corroborou

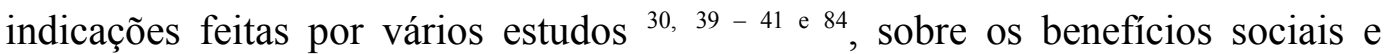
psicológicos que a primeira gravidez pareceu trazer às adolescentes.

Não se pode negar, portanto, que a gravidez pareceu dar-lhes algum direcionamento na vida, idéia que a maioria, prontamente, parece ter encampado. Algumas deixaram de fumar, de usar drogas, outras deixaram de passear, de 
gastar, muitas referiram que 'mudaram a cabeça' e o comportamento. Passaram a compreender a mãe e o mundo. Tudo em nome do ideal materno e das representações que tinham em torno do que era ser mãe. O mesmo fenômeno foi observado quando elas se referiram aos parceiros, que também se sentiram honrados com a paternidade, conforme também observado por HEILBORN ${ }^{57}$.

Contudo, esse panorama das adolescentes que ficaram grávidas pela primeira vez desejando a gravidez é, consideravelmente, diferente do cenário daquelas que não desejaram a gravidez, especialmente, na segunda e terceira maternidade. Na primeira gravidez, 53\% das mães adolescentes 'não queriam', na segunda, $61,4 \%$ e na terceira, $100 \%$. Justificaram que as maternidades estavam 'fora dos planos', pois percebiam que 'era muito cedo', que estavam 'muito novas'. Disseram ainda, que apesar de saberem disso, a gravidez 'simplesmente lhes acontecera', o que pareceu, provocou-lhes sentimentos contraditórios sobre a situação, como o estranho sentimento de que 'foram invadidas'.

Frente ao 'não querer' e a impotência frente à situação, sobrou-lhes considerar a possibilidade de provocar o aborto, o que nesses casos, não ocorreu. Então, pareceu que a única saída foi se sujeitarem à 'força social da experiência materna' e ao 'destino materno', acompanhadas do pai do filho ou permanecendo no grupo familiar onde estavam. Ao longo da gestação, a maioria descobriu que a maternidade proporcionava algumas gratificações e acabaram aceitando a maternidade, algumas de 'bom grado', outras, a 'contra gosto'. Pelo observado, logo descobriram também que, pouco a pouco, as gratificações se transformavam em responsabilidades, aliás, descoberta feita também pelas que desejaram a maternidade.

Coincidentemente, o percentual de adolescentes que disse não ter desejado o primeiro filho, 53\%, foi o mesmo percentual de adolescentes que referiram ter usado métodos contraconceptivos antes da primeira gravidez, o que parece justificar que, $36,8 \%$ das participantes, tenham levado mais de doze meses para ficar grávida após terem iniciado a vida sexual.

Observou-se, de igual modo, que houve considerável aumento do 'uso de contraceptivos' - especialmente de "pílulas" - antes da segunda e terceira maternidade, aparentemente, na mesma proporção em que diminuiu o desejo pelo 
filho seguinte, assim como, aumentaram as intenções de provocar o aborto na segunda e terceira gravidez.

Pareceu, portanto, que a adesão aos contraceptivos envolve a elaboração de ambigüidades entre 'ser' e 'não ser mãe', entre 'posso' e 'não posso'. Entretanto, isso parece fazer algum sentido para aquelas adolescentes que tiveram informações e acesso aos contraceptivos, tendo em vista, que aquelas que não tiveram acesso, aparentemente, nem chegaram a vivenciar esse conflito. Conclui-se, portanto, que o desejo pela maternidade e a maior ou menor ambigüidade do como ele é vivenciado, parecem colaborar para que as adolescentes adotem ou não os contraceptivos e os utilizem de maneira adequada ou não. Para, além disso, a ambigüidade do desejo materno parece relacionar-se com as tentativas de provocar o aborto.

Vislumbra-se, assim, do ponto de vista das adolescentes, outra visão para a questão do planejamento das gravidezes. Uma parte delas parece que sempre desejou a maternidade, e por isso, não se importaram em conhecer e recorrer aos contraceptivos. Houve outra parte, que não desejou e, aparentemente, por isso, recorreram aos contraceptivos. E, provavelmente, houve uma terceira parte, que não identificou qual era o desejo e 'correram os riscos'.

Não se pode dizer, portanto, que não houve planejamentos. Ou seja, o discurso da não adesão aos planejamentos e aos contraceptivos é exterior às adolescentes. Quando considerarmos o olhar da adolescente-mãe, observamos que seus planejamentos seguem outra lógica.

Temos assim, que dois contextos delineiaram-se na abordagem das maternidades sucessivas na adolescência. $\mathrm{O}$ primeiro referiu-se à ocorrência da primeira gravidez que, apesar de muitas vezes surgir em situações pouco estruturadas, pareceu logo se associar ao 'desejo materno’ e às gratificações sociais decorrentes. O segundo contexto aproximou-se mais do 'não querer' e aos 'atrapalhos' sócio-econômicos presentes na criação de vários filhos.

Também entre os parceiros, a satisfação com a nova gravidez diminuiu na segunda e na terceira gravidez, grande parte, motivada pela avaliação das condições financeiras em que viviam. Muitas fugas de parceiros pareceram ser justificadas por não conseguirem pagar a pensão e correrem o risco de serem 
presos. Curiosamente, o Estado, na ânsia de proteger, 'criminaliza' situações que deveriam ser resolvidas numa outra esfera.

Temos, com isso, que as histórias sobre a segunda e terceira maternidade não mais continham o entusiasmo da primeira. Ao contrário, foram muitas as referências de que perderam autonomia e liberdade e de que não podem mais fazer isso e aquilo. O status social alcançado com a primeira maternidade dissolveu-se. As gratificações viraram duras obrigações do cotidiano e da criação dos filhos.

Pelo observado, às precárias condições de vida se ligou a 'tamanha preocupação e decepção' sentida por $71,4 \%$ das adolescentes aos descobrirem-se grávidas pela segunda vez. As dificuldades financeiras pareceram ser um dos maiores entraves para querer bem a segunda e terceira maternidade. Nesse sentido, muitas pareciam, antes da nova gravidez, aguardar o crescimento do primeiro filho para tomar alguma providência, como separar-se, ir embora, trabalhar, entre outras coisas. Ledo engano!

Ademais, o não desejo pela nova maternidade decorreu também do fato dela ter-lhes ocorrido em período tão próximo ao filho anterior, rompendo com certo planejamento que pareciam ter e que até considerava a possibilidade de outras gravidezes, mas em outro momento da vida - e até mesmo, com outro parceiro.

Novamente, há que destacar que o percentual de mães adolescentes que desejaram a segunda maternidade, $28,6 \%$, coincide com o percentual daquelas que se mostraram satisfeitas com a nova maternidade. Geralmente, para essas, as preocupações foram de outra natureza, como descobrir qual era o sexo do bebê.

Finalmente, o quadro geral desenhado por essas argumentações demonstra que para a maioria das adolescentes com maternidades sucessivas, a primeira maternidade foi desejada e lhes trouxe consideráveis benefícios frentes às condições de vida em que sobreviviam. Entretanto, essas mesmas condições mostraram-se duras realidades para o prosseguimento da criação do primeiro filho e dos seguintes, o que levou a maioria delas, a não desejar a segunda e terceira maternidade e a vivenciá-las de modo diferente ao ocorrido na primeira vez. 
Esses aspectos permitem concluir que houve, no grupo estudado, diferenças substanciais entre a primeira maternidade e as demais. Enquanto as primeiras maternidades foram norteadas por certo desejo e vivenciadas como um sentido de 'busca de si’ por meio da maternidade, as outras, não se pautaram pelos mesmos anseios. Esse 'não querer' pareceu ser condicionado pelas próprias e precárias condições sócio-econômicas que dificultavam a criação dos filhos.

Pode-se afirmar, portanto, que os valores sobre a maternidade são diferentes nas maternidades sucessivas quando comparados aos valores dos contextos de ocorrência de apenas uma gravidez na adolescência. 


\section{8 - As Maternidades Sucessivas e a 'Periferia da Periferia'}

A análise de vários aspectos que compõem o contexto sócioeconômico em que se encontravam as adolescentes com maternidades sucessivas indicou condições de vida, geralmente, muito precárias, coadunando com as indicações feitas por CAVASIN e col. ${ }^{33}$, quando diz que grande parte da população jovem vive em periferias, com baixa renda e pouca escolaridade.

O mapeamento da localização das residências das adolescentes revelou que residiam em edificações precárias e mais pobres que as circundantes e em 'casas/barracos/cômodos' que estavam, na maioria das vezes, localizadas nos lugares menos valorizados dos bairros, próximos aos riachos e situados no fim das vilas, em ruas de difícil acesso e sem asfalto.

A essa distribuição geográfica no plano urbano e que expressou as condições de vida das adolescentes, convimos chamar de 'periferia da periferia'. Ou seja, as maternidades sucessivas estão distribuídas nos pontos extremos da cidade, justamente, nos lugares mais pobres e de difícil acesso aos bens comunitários e àqueles oferecidos pelo poder público.

Associam-se a esse indicador, as poucas oportunidades de empregabilidade e trabalho e a precária composição de renda. Embora 75\% das adolescentes tenham referido já ter tido algum trabalho remunerado, no momento da última gravidez, todas estavam desempregadas e dependendo da renda de outras pessoas para sobreviverem. Entre os parceiros tidos como provedores, $65,3 \%$ ganhavam até 1,5 salários.

A situação pouco se modificou quando comparou o total da renda do grupo familiar com os qual coabitavam, pois, compôs uma renda de até 1,5 salários, 53,1\% dos grupos familiares. O percentual de domicílios em que elas residiam e que não tinha nenhuma pessoa trabalhando chegou a 14,3\% e, que apenas uma pessoa trabalhava, a 47\%, percentual muito próximo ao indicado pela Prefeitura Municipal de Rondonópolis-MT/ACIR ${ }^{95}$, em que 45,3\% dos chefes de família do município ganhavam até $\mathrm{R} \$ 424$ reais por mês. Temos, portanto, vários indicadores que apontam contextos de grande pobreza para cerca de metade das adolescentes com maternidades sucessivas. 
Há que acrescentar que a outra parte das adolescentes (25\%) encontrava-se em situação melhor, mas não era nada substancial que as tirassem da linha da pobreza. Esses dados confirmam também, o estudo realizado por PERSONA e col. ${ }^{89}$, quando diz que a repetição da gravidez está associada à ausência de ocupação remunerada e baixa renda familiar.

Juntam-se a esses dados, as dificuldades de acesso à escolarização, representadas, principalmente, pela dificuldade de manter-se estudando após as maternidades e, conseqüentemente, à baixa escolaridade. Apenas 22,5\% concluíram o primeiro grau, dado consideravelmente menor que o encontrado por HEILBORN e col. ${ }^{24}$, em que 59,3\% das adolescentes com filhos antes dos 20 anos haviam completado o primeiro grau.

A repetência escolar, ocorridas, principalmente, na primeira série $(25,0 \%)$, na quinta série $(22,0 \%)$ e na sexta série $(18,8 \%)$ foram eventos que ocorreram antes da primeira maternidade, enquanto que a evasão escolar ocorreu parte antes da primeira gravidez e outra parte logo após.

Houve algumas adolescentes que após o primeiro parto, retomaram os estudos, mas abandonaram definitivamente com a segunda gravidez. A maior concentração de evasão ocorreu na sexta série, $20,4 \%$ e na sétima, 22,4\%. Considerando que todas tinham menos de vinte anos e 97,9\% havia abandonado a escola, esse dado é consideravelmente maior que os encontrados por ABRAMOWAY e col. ${ }^{01}$, em que $42 \%$ referiram dificuldades para continuar seus estudos após a gravidez e por HEILBORN ${ }^{55}$, que $42,1 \%$ das adolescentes com menos de 20 anos e que tiveram filhos estavam fora da escola.

Chama atenção que as repetências na quinta e sexta série coincidem com a chegada da adolescência e o alvorecer da sexualidade. De outra forma, a evasão escolar, coincidiu com a iniciação sexual e a primeira gravidez. O retorno à escola após a evasão e maternidades, mostrou-se obstaculizado, principalmente, por não ter com quem deixar os filhos e pelos cuidados que a eles deveriam destinar. Esses dados são consoantes aos apresentados por BERQUÓ e col. ${ }^{16}$ sobre as dificuldades de adolescentes mães permanecerem estudando em contextos de pobreza, educação de baixa qualidade e falta de oportunidade de empregos. 
Todos esses dados confirmam estudo realizado por BRASIL ${ }^{27}$, quando afirma que "a pobreza e as dificuldades de construção de projetos de vida para a adolescência e a juventude no Brasil se deve a muitos fatores estruturantes das condições sociais dessa população e a um contexto mais amplo de falta de direitos" (p.21).

Embora o universo estudado tenha se referido aos usuários do SUS, não são apenas as periferias extremamente pobres que o utilizam. Seria esperado que considerável número de adolescentes de vilas com nível sócio-econômico com renda maior também apresentasse suas moradoras-adolescentes com maternidades sucessivas.

Mas não foi o que observamos. Nesse sentido, vários pesquisadores ${ }^{01}$, 13, 11, 28, 30 e 128 apontam para a estreita relação entre gravidez na adolescência e indicadores da qualidade de vida de cada região. Por isso sugerimos que as maternidades sucessivas na adolescência parecem caracterizar um fenômeno visceralmente ligado às situações de grande pobreza e, conseqüentemente, de maior vulnerabilidade. 


\section{9 - CONSIDERAÇÕES FINAIS}

O município de Rondonópolis-MT comporta em suas características sócio-demográficas os vestígios da forma como se desenvolveram outras regiões do Brasil. Em parte, incorporou os avanços do sul/sudeste e em outra, ressente-se pelo isolamento desenvolvimentista ao qual a região centro-norte-nordeste esteve fadada por décadas. Por um lado, o agronegócio e a agroindústria são setores dos mais desenvolvidos do país, mas, por outro, padece com algumas mazelas sociais, algumas típicas de regiões subdesenvolvidas, decorrentes em parte do rápido aumento populacional e, em outra, da falta de priorização das políticas públicas.

Os dados levantados em Rondonópolis-MT, no período 2000/2006, permitiram concluir que o município apresentou características reprodutivas na população adolescente que acompanharam a dinâmica reprodutiva de adolescentes verificada no restante do país, que se caracterizou, nos últimos anos, pela diminuição de gravidezes na adolescência. Em Rondonópolis-MT, o percentual saiu de um pico de 29,3\%, ocorrido em 2001, caindo para 23,8\%, em 2006.

Do mesmo modo, encontramos dados que indicaram que as maternidades sucessivas em adolescentes estão diminuindo simultaneamente às 'primeiras maternidades'. Saiu de uma situação de pico, 26,8\%, em 2000, para 19,0\%, em 2006, permitindo afirmar que em 2000, a razão era de 1 adolescente com maternidades sucessivas para cada 3,7 adolescentes na 'primeira maternidade'. Em 2006, a razão foi de 1 para cada 5,2. A diminuição equivalente nas duas categorias refuta a hipótese aventada para a qual a diminuição das 'primeiras maternidades na adolescência' não seria acompanhada pela queda dos percentuais de segunda ou mais maternidades ainda na adolescência. Nesse sentido, foram caracterizados como fenômenos homogêneos.

Apuramos também, que, as maternidades sucessivas ocorreram predominantemente, entre as adolescentes mais pobres, o que colaborou para que permanecessem com baixa escolaridade. Se com um filho ainda encontravam 
meios e perspectivas de retornar à escolarização, com dois ou mais, definitivamente se afastaram e se entregaram à criação dos filhos e afazeres domésticos.

Conquanto, se do ponto de vista percentual e mesmo do número absoluto de nascidos vivos, as maternidades sucessivas na adolescência não representaram uma quantidade considerável frente aos nascidos vivos em outras faixas etárias, 4,6\% no ano 2006, há que destacar que os contextos onde ocorreram esses nascimentos foram caracterizados por grandes desigualdades sociais e precárias condições de vida. Esse quadro pareceu configurar situações de grande vulnerabilidade, conjuntura em que a ausência de alguns recursos para a criação dos filhos, como creches, colaboraram para a sua perpetuação.

A despeito de várias indicações que associam idade da menarca e da iniciação sexual às gravidezes na adolescência, a investigação correlacionou que a gravidez em 'menores de 15 anos' contribui muito menos do que comumente é aventado, pois corresponderam a apenas $25 \%$ das maternidades sucessivas.

Assim, concluiu-se que, nessa proporção, as maternidades sucessivas se correspondem com as maternidades em 'menores de 15 anos', mas no restante, são determinadas por condições que ocorrem após os 15 anos e que, conforme analisado, compõem um cenário que está em transformação e colaborando para a diminuição de maternidades na faixa etária acima dos 15 anos.

Entretanto, tendo em vista, que permaneceu vigoroso o percentual de maternidades em 'menores de 15 anos', apontou-se que a tendência é que, nessa faixa etária, aumentará a proporção das maternidades em relação às demais maternidades, sucessivas ou não na adolescência e no restante da população. Esse fenômeno já pôde ser observado no período 2000/2006. Em 2000 tínhamos 1 FNV em 'menores de 15 anos' cada 7,3 FNV em 'adolescentes com maternidades sucessivas'. Em 2006, 1 para cada 4.

De maneira geral, a análise dos dados demográficos permitiu concluir que a redução das maternidades sucessivas na adolescência é um aspecto interno ao fenômeno da redução das taxas de fecundidade total do país, verificada na PNAD/2004, principalmente, na população mais pobre e menos escolarizada. 
Ainda, a respeito da idade da iniciação sexual e da primeira maternidade, a análise do que ocorreu no intervalo entre um evento e outro se mostrou melhor aproveitada como indicador que os demais dados. Ela pode contemplar dimensões mais refinadas, como as 'vulnerabilidades' e escapa, por exemplo, da concepção de precocidade. A iniciação sexual, a primeira gravidez e nova gravidez podem ocorrer em intervalos curtos ou longos, independentemente do fator idade.

Deriva desse tipo de análise, a recomendação para a intensificação das ações de saúde no 'pós-natal', tendo em vista que as maternidades sucessivas, principalmente, as indesejadas, ocorrem em curto intervalo após o parto anterior, acentuando as dificuldades cotidianas e de vida das jovens mães, até mesmo, prejudicando os cuidados ao recém-nascido anterior. Outra recomendação, nesse sentido, passa pela garantia de creche às adolescentes que retomarem os estudos, inclusive, no período noturno.

A respeito das parcerias afetivo-sexuais, concluímos que as iniciações ocorreram em 93,8\% em parcerias que tinham alguma estabilidade, o que pareceu ser um indicador louvável, tendo em vista que esse tipo de parceria, diferentemente das eventuais, parecem constituir-se em ambientes mais consistentes para a construção de acordos entre pares, como a adoção de contraceptivos. Entretanto, o estabelecimento de confiança entre parceiros parece ser uma dimensão paradoxal das vivências humanas, pois para muitas adolescentes, a confiança no parceiro motivou que abandonassem o uso dos preservativos.

Predominantemente, as parcerias se estabeleceram em torno do 'morar junto', que se caracterizou por uma série de compromissos comuns para a administração do cotidiano, com o pressuposto da fidelidade sexual entre os parceiros e com divisão de papéis típicos da família nuclear. Nas condições observadas, de baixa renda, esse cenário tornou as adolescentes extremamente dependentes dos parceiros, quando não, das famílias de origem, o que só fez diminuir o 'empoderamento' e aumentar as desigualdades.

Diferentemente do alardeado, as experiências sexuais das adolescentes, em sua maioria restringiu-se ao(s) parceiro(s) pai(s) do(s) filho(s), o que não quer 
dizer, por exemplo, que diminuíram seus riscos à infecção ao HIV. Aliás, nesse sentido, recomenda-se maior inclusão dos parceiros nos procedimentos do prénatal, como na realização do teste HIV e de Sífilis, com horários de aconselhamentos e coletas noturnos.

O estudo detectou também, dificuldades de informações e acesso aos contraceptivos, mas, muito maior foi a falta de significação dos contraceptivos frente às vivências cotidianas desse segmento populacional. Isso permitiu concluir que, o uso correto ou inadequado dos contraceptivos, para além da falta de informações e integração delas às vivências pessoais, pode mediar-se pela ambivalência produzida pelo conflito entre 'ter' ou 'não ter filhos', num contexto em que a maternidade é um valoroso distintivo social e tem um forte apelo afetivo.

Isso sugere, portanto, que os trabalhos de sensibilização para o uso de contraceptivos devem ir muito além das prescrições médicas, se a opção for pelo aumento das gravidezes planejadas. Ademais, chamou atenção e necessita de investigação específica, o grande número de adolescentes que referiu ter usado corretamente os contraceptivos e, mesmo assim, ficaram grávidas novamente.

A respeito do aborto, observou-se que uma em cada quatro, na primeira gravidez, e uma em cada três, na terceira, teve a idéia, plano ou efetivamente tentou provocá-lo. Vários indicativos levaram a concluir que muitas adolescentes teriam provocado-o, desde que tivessem certeza que o completariam, pois o medo do insucesso e do desamparo nessa situação, mais que conflitos éticos, morais e religiosos, desmobilizaram grande parte de seus intentos.

As intenções de provocar o abortamento pareceram diretamente relacionadas a dois aspectos: a) não desejo de ter um filho naquele momento e/ou com aquele parceiro; b) receio de que não conseguiria criá-lo, ora por se sentirem impotentes frente à própria situação e/ou por considerarem como precárias as condições sócio-econômicas das quais dependiam.

Parece razoável, portanto, sugerir que para além da descriminalização do aborto, esforços sejam envidados pelas políticas públicas para a melhoria das condições de vida da população, o que certamente, colaborará para o aumento das gravidezes planejadas. 
A investigação acerca do desejo das adolescentes pela maternidade levou à reflexão de que o planejamento da vida sexual e das maternidades é um valor cultural das classes sociais cooptadas por certos modos de vida e que, portanto, a escolarização e a profissionalização são valores muito distantes das vivências das periferias nas condições em que se encontram. 'Lá' os desejos, valores e necessidades são outros, nem por isso, menos dignos.

Nesse afã, dois contextos foram caracterizados. O primeiro refere-se à desejabilidade da primeira gravidez, que, geralmente foi bem quista pela adolescente, pois, pareceu vislumbrar na maternidade, o sentido de construção de si e de seu mundo. De outro modo, o segundo contexto, que se pautou pela indesejabilidade da segunda e demais maternidades, caracterizando, portanto, importante mudança dos valores sobre a maternidade.

Essa mudança se deu, principalmente, em função das condições sócioeconômicas em que as adolescentes viviam e que pareceram contribuir em maior ou menor grau, para a indesejabilidade da segunda e demais maternidades, diferentemente do que ocorreu com a primeira maternidade, onde a valoração social e pessoal da maternidade pareceu influenciar em maior proporção.

Observou-se também que os indicadores referentes às condições sócioeconômicas das adolescentes com maternidades sucessivas foram, geralmente, piores que aqueles encontrados por outros estudos cujos objetivos foram estudar a gravidez na adolescência. Essa característica reforçou as indicações de que as maternidades sucessivas se diferenciam da 'gravidez na adolescência'.

Assim, se a primeira maternidade forneceu sentidos positivos para muitas das vivências das adolescentes e até colaborou para que construíssem uma identidade - ser mãe - e passassem a ocupar um lugar socialmente valorizado, as maternidades sucessivas pareceram ter contornos menos estruturantes, até mesmo, agravando as já precárias condições sócio-econômicas que as circundavam. Essa situação, pareceu igualmente ter impedido-lhes o acesso às 'janelas de oportunidades', principalmente, aquelas articuladas à escolarização.

Concluiu-se que as 'maternidades sucessivas na adolescência' constituem-se, pelas suas conseqüências, num fenômeno diferente ao da 'primeira gravidez na adolescência'. Enquanto essa se mostrou mais integrada às demandas 
da adolescente, as maternidades subseqüentes agravaram suas necessidades, multiplicando as situações adversas a elas associadas.

Finalmente, há que destacar que os dados encontrados se caracterizaram muito mais pela variedade do que por regularidades, o que de certa forma, explicita as tensões presentes nas maternidades sucessivas na adolescência, tornando-as um fenômeno demasiadamente complexo. 


\section{0 - REFERÊNCIAS}

1. ABRAMOWAY, M.; GARCIA, M.; SILVA, L.B. Juventudes e sexualidade. Brasília: UNESCO/Brasil, 2004.

2. ADORNO, R. Capacitação solidária: um olhar sobre os jovens e sua vulnerabilidade social. São Paulo: AAPCS, 2001.

3. ALAN GUTTMACHER INTITUTE. Into a new world: young women sexual and reproductive live. New York, 1998.

4. ALMEIDA, M. C. C. et al. Uso de contracepção por adolescentes de escolas públicas na Bahia. Revista de Saúde Pública, São Paulo, n.37, p. 566-575. 2003.

5. AQUINO E. M. L. et al. Adolescência e reprodução no Brasil: a heterogeneidade dos perfis sociais Caderno de Saúde Pública, Rio de Janeiro, v.19, supl. 2, p.377-388, 2003.

6. ARIÈS, P. História social da criança e da família. Rio de Janeiro: Zahar Editores, 1978.

7. ATKIN, L. C; ALATORRE-RICO, J. Pregnant again?: psychosocial predictors of short-interval repeat pregnancy among adolescent mothers in Mexico City. The Journal of Adolescent Health, New York, v. 13, n. 8, p.700-706, Dec. 1992.

8. AYRES, J. R. C. M; FRANÇA Jr., I.; CALAZANS, G. J. Aids, vulnerabilidade e prevenção. In Anais do II Seminário de saúde reprodutiva em tempos de Aids, Rio de Janeiro: ABIA/IMS, p.20-37, 1997.

9. BARDIN, L. Análise de Conteúdo. Lisboa: Edições 70, 1977.

10. BEMFAM. Pesquisa Nacional sobre Demografia e Saúde-1996. Rio de Janeiro, 1997.

11. BERQUÓ, E. Panorama da saúde reprodutiva no Brasil. Campinas, Editora da Unicamp, 2003.

12. BERQUÓ, E. O rejuvenescimento da fecundidade [on line] CEBRAP, São Paulo. Disponível em www.cebrap.org.br.pesqui_pop_soc.htm. Acesso em 12 de julho de 2007.

13. BERQUÓ E. et al. Mais velho e mais urbano: quatro pesquisadores analisam as transformações registradas no país a partir de estatísticas recentes. Jornal da UNICAMP, Campinas. Ed. 238, 17 a 30 nov. 2003, p.5. 
14. BERQUÓ, E.; CAVENAGHI, S. Breve nota sobre a redução no número médio de filhos por mulher no Brasil. Novos Estudos, Rio de Janeiro: CEBRAP, n.74, p. 11-15, mar. 2006.

15. BERQUÓ, E.; CAVENAGHI, S. Gravidez na adolescência cai 10,5 \% no País. Folha de São Paulo, São Paulo-SP, 19 jun. 2005. Cotidiano, p. c2-c2.

16. BERQUÓ, E.; CAVENAGHI, S. Increasing adolescent and youth fertility in Brazil: A new trend or a one-time event? In: Anais do Annual Meeting of The Population Association of America (PAA), 2005, Philadelphia, Pennsylvania. Session 151, adolescent fertility in developing countries. Philadelphia: Annual Meeting of the Population Association of America, Philadelphia, 2005.

17. BORDIEU, P. A 'Juventude' é apenas uma palavra. In: BORDIEU, P. A Questões de sociologia. Rio de Janeiro: Marca Zero, p.136-163,1983.

18. BORGES, A. L. Adolescência e vida sexual: Análise do início da vida sexual de adolescentes residentes na zona leste do município de São Paulo, 2004, Tese (Doutorado em Saúde Pública) - Faculdade de Saúde Pública, Universidade de São Paulo, São Paulo. 2004.

19. BRANDAO, E. R.; HEILBORN, M .L. Sexualidade e gravidez na adolescência entre jovens de camadas médias do Rio de Janeiro, Brasil. Caderno de Saúde Pública, Rio de Janeiro, v. 22, n. 7, p.1421-1430, 2006.

20. BRASIL Ministério da Saúde, Ministério da Criança/Projeto Minha Gente ECA (Estatuto da Criança e do Adolescente). Brasília, 1991.

21. BRASIL Ministério da Saúde. Programa de saúde do adolescente: bases programáticas. Brasília-DF: Ministério da Saúde, 1996.

22. BRASIL MINISTÉRIO DA SAÚDE; CEBRAP - Centro Brasileiro de Análise e Planejamento. Pesquisa sobre comportamento sexual e percepções da população brasileira sobre HIV/AIDS. Brasília: Ministério da Saúde/PN-DST/AIDS, 2000.

23. BRASIL Ministério da Saúde, Secretaria de Vigilância em Saúde SAÚDEBRASIL 2004: uma análise da situação de saúde. Brasília: Ministério da Saúde, 2004.

24. BRASIL Ministério da Saúde, Secretaria de Vigilância em Saúde. SAÚDEBRASIL 2005: uma análise da situação de saúde no Brasil. Brasília: Ministério da Saúde, 2005.

25. BRASIL Ministério da Saúde. DATASUS/SINASC: Sistema de Informações de Nascidos Vivos. Brasília - DF. 2007. Acesso em: Mai. 2007. 
26. BRASIL Ministério da Saúde, Secretaria de Vigilância em Saúde SAÚDEBRASIL 2006: uma análise da desigualdade em saúde. Brasília: Ministério da Saúde, 2006.

27. BRASIL Ministério da Saúde. Secretaria de Atenção à Saúde. Departamento de Ações Programáticas Estratégicas. Marco teórico e referencial: saúde sexual e saúde reprodutiva de adolescentes e jovens (Versão Preliminar). Série B. Textos Básicos de Saúde. Brasília: Ministério da Saúde. 2006.

28. CABRAL, C. S. Gravidez na adolescência nas camadas populares do Rio De Janeiro: um 'problema' de classe ou geração? In: Anais do décimo terceiro encontro da Associação Brasileira de Estudos Populacionais. Ouro Preto. Belo Horizonte: ABEP, out. 2002.

29. CAMARANO, A. A. Fecundidade e anticoncepção da população jovem. In CNPD - Comissão Nacional de População e Desenvolvimento. Jovens acontecendo na trilha das políticas públicas. Brasília, v.1, p.109-134, 1998.

30. CARVALHO, J. E. C. How can a child be a mother?: Discourse on teenage pregnancy in a Brazilian favela. Culture, Health \& Sexuality, Londres, n.9, v.2, 109-120, Mar.-Apr. 2007.

31. CASTRO, M. G.; ABRAMOWAY, M. Drogas nas escolas. Brasília: UNESCO, Coordenação Nacional de DST/AIDS do Ministério da Saúde, Secretaria de Estado dos Direitos Humanos do Ministério da Justiça/CNPq/ Instituto Ayrton Senna/UNAIDS/Fundação Ford/CONSEDE/UNDIME, 2002.

32. CASTRO, M.G.; ABRAMOWAY, M. Por um paradigma do fazer políticas: políticas de/para/com juventude. Brasília: UNESCO, 2003.

33. CAVASIN, S. (Coord.) et al. "Gravidez de adolescentes entre 10 e 14 anos e vulnerabilidade social": estudo exploratório em cinco capitais brasileiras. Relatório de pesquisa. Rio de Janeiro: ECOS-Comunicação em Sexualidade, 2004.

34. CHABAN Jr. N.; MAQUERA, A. E. R.; LOPES, C. M. Prevalência da gravidez em adolescentes em Vila Acre-AC/Brasil. Online Brazilian Journal of Nursing, n.2, v.3, dez. 2003. Disponível em www.uff.br/nepae. Acesso em: 12 Jul. 2006.

35. CHEMELLO, C. S. Perfil Epidemiológico das adolescentes grávidas na cidade de São Marcos-RS. 1999. Dissertação (Mestrado em Saúde Pública) Faculdade de Saúde Pública. Universidade de São Paulo. 1999.

36. COARD, S. et al. Predictors of repeat pregnancy in urban adolescent mothers. Journal Adolescence Health, San Francisco - EUA, n.22, v.2, p.173, Feb. 1998. 
37. CORREA, M. M.; COATES, V. Implicações sociais e o papel do pai. In: MAAKAROUN, M. F., SOUZA R.P, CRUZ, A.R. Tratado de Adolescência. Rio de Janeiro: Cultura Médica, p.408-415, 1991.

38. D'URUNG, M. C. Analyse de contenu e Acte de Parole. Paris: Editions Universitaires, 1974.

39. DADOORIAN, D. A gravidez desejada na adolescência. Arquivos Brasileiros de Psicologia, Rio de Janeiro, n.50, v.3, p.60-70, 1998.

40. DADOORIAN, D. Um novo olhar sobre a gravidez na adolescência: Pronta para voar. Rio de Janeiro: Rocco, 2000.

41. DADOORIAN, D. Gravidez na Adolescência: um novo olhar. Psicologia Ciência e Profissão, Brasília, v.23, n.1, p.84-91, mar. 2003,

42. DUARTE, T. Porto Alegre usa implante no combate à gravidez precoce. 2006. Disponível em www.g1.globo.com/Noticias/Brasil. Acesso em: 27 nov. 2006.

43. FERRAZ, E.; FERREIRA, I. Q. Início da atividade sexual e características da população adolescente que engravida. In Vieira, E.M.; Fernandes, M.E.L.; Bayley, P.; McKay, A. (org). Seminário Gravidez na adolescência. Rio de Janeiro, 1998.

44. FOIX-L'HÉLIAS, L.; BLONDEL, B. Changes in risk factors of preterm delivery in France between 1981 and 1995. Pediatrics Perinatal Epidemiology, Cincinnati - EUA, n.14, p. 314-323, 2000.

45. FONSECA, W. M. C. et al. Características sócio-demográficas, reprodutivas e médicas de mulheres admitidas por aborto em hospital da Região Sul do Brasil. Caderno de Saúde Pública, Rio de Janeiro, n.14, v.2, p.279-286, abrjun, 1998.

46. FOUCAULT, M. História da sexualidade. v. I, II, III. $11^{\text {a }}$ ed. Rio de Janeiro: Graal, 1993.

47. FREUD, S.Três Ensaios Sobre a Teoria da Sexualidade (Trad. Jaime Salomão) Edição Standard Brasileira das Obras Psicológicas Completas de Sigmund Freud. Vol. VII. Rio de Janeiro: Imago. [1905] 1976.

48. FREYRE, G. Casa grande \& Senzala: Formação da família brasileira sob o regime da economia patriarcal, 50ª ed., São Paulo: Global, 2005.

49. GALLAND, O. Sociologie de la jeunesse. Paris: Armand Colin, 1997.

50. GOMES R.; MENDONÇA E. A. A Representação e a Experiência da Doença: Princípios para a pesquisa qualitativa em saúde. In MINAYO, M.C.; 
DESLANDES S. F. (Org.) Caminhos do pensamento: epistemologia e método. Rio de Janeiro: Fiocruz, 1999.

51. GROSSMAN, E.; CARDOSO, M. H. C. As bases conceituais dos documentos oficiais de atenção à saúde do adolescente. Revista Brasileira Crescimento e Desenvolvimento Humano, São Paulo, n.7, v.2, p.1-11, jul.-dez. 1997.

52. HEILBORN, M.L. Gênero e condição feminina: uma abordagem antropológica. Mulher e políticas públicas. Rio de Janeiro: IBAM/UNICEF, p. $23-28,1991$.

53. HEILBORN, M. L. O traçado da vida: Gênero e idade em populares do Rio de Janeiro. In: MADEIRA, F. (org.), Quem mandou nascer mulher: estudo sobre crianças e adolescentes pobres no Brasil. Rio de Janeiro: Rosa dos Tempos, p. 295-342, 1997.

54. HEILBORN, M. L. Construção de si, gênero e sexualidade. In: HEILBORN, M.L. (org.) Sexualidade: o olhar das Ciências Sociais. Rio de Janeiro: Zahar, 1999.

55. HEILBORN, M. L. et al. O Aprendizado da sexualidade: reprodução e trajetórias sociais de jovens brasileiros. Rio de Janeiro: FIOCRUZ/Garamond, 2006.

56. HEILBORN, M. L. et al. Gravidez na adolescência estudo multicêntrico sobre jovens, sexualidade, e reprodução no Brasil In: Anais do VI Congresso Brasileiro de Saúde Coletiva, Salvador: ABRASCO, p. 28 - 31, ago 2000.

57. HEILBORN, M. L. et al. Aproximações socioantropológicas sobre a gravidez na adolescência. Horizontes Antropológicos, Porto Alegre, v.8, n.17, p.1345, Jun 2002.

58. IBGE (Instituto Brasileiro de Geografia e Estatística). [on line] Censo: 2000. Disponível em: http://www.ibge.gov.br. Acesso em: 10 ago. 2007.

59. JACOBY, M. et al. Rapid repeat pregnancy and experiences of interpersonal violence among low-income adolescents. American Journal of Prevent Medicine, n.16, v.4, p. 318 - 21, May 1999.

60. KALMUSS, D. S.; NAMEROW, P. B. Subsequent childbearing among teenage mothers: The determinants of a closely spaced second birth. Family Planning Perspectives, n. 26 v.4, p. 149-153. jul. - aug., 1994.

61. KERSHAW, T. S. et al. Short and long-term impact of adolescent pregnancy on postpartum contraceptive use: Implications for prevention of repeat pregnancy. Journal Adolescence Health, San Francisco, n.33, v.5, p.359368, nov. 2003. 
62. KINSMAN, S. B., ROMER.; D, FURSTENBERG, F. F.; SCHWARZ, D. F. Early sexual initiation: the role of peer norms. Pediatrics, n.120, v.5, p.11851192, 1998.

63. LABOV, W. The Transfomacion of experience in narrative syntax. In Labov, W. Language in the inner city: studies in the Black English Vernacular, Oxford: Basil Blackewell, p. 354-396, 1977.

64. LEVISKY, D. L. (Org.). Adolescência e violência: ações comunitárias. São Paulo: Casa do Psicólogo, 2001.

65. LIMA, C. T. B. et al. Percepções e práticas de adolescentes grávidas e de familiares em relação à gestação. Revista Brasileira de Saúde Materno Infantil, Recife, v.4 n.1, p. 71 - 83, jan./mar. 2004.

66. LINARES L. O. et al. Predictors of repeat pregnancy outcome among black and Puerto Rican adolescent mothers. Journal Developmental and Behavioral Pediatrics, n.13, v.2, p. 89-94, Apr 1992.

67. LIRA, G. V; CATRIB, A. M. F.; NATIONS, M. K. A narrativa na pesquisa social em saúde: perspectiva e método. Revista Brasileira de Promoção de Saúde. Fortaleza, v.3 n.1/2, p.59-66, 2003.

68. MAIA, V. O. A. et al. Via de parto em gestações sucessivas em adolescentes: estudo de 714 casos. Revista Brasileira de Ginecologista e Obstetrícia, Rio de Janeiro, n.26, v.9, p.703-707, out. 2004.

69. MARIOTONI, G. G. B.; BARROS FILHO, A. A. Peso ao nascer e características maternas ao longo de 25 anos na maternidade de Campinas. Jornal de Pediatria, Rio Janeiro, n.76, p.55-64, 2000.

70. MELO, A. V.; YAZAKI, L. M. O Despertar do desejo. In: Fundação SEADE. 20 Anos no ano 2000: estudos sociodemográficos sobre a juventude paulista, São Paulo, p.119-125, 1998.

71. MINAYO, M. C. S. O desafio do conhecimento: pesquisa qualitativa em saúde, 5aed., São Paulo: Hucitec, 1998.

72. MIRÓ, C. Demógrafa critica controle da natalidade no país In: Folha de São Paulo. São Paulo, 27 set. 2004. Cotidiano p. C1

73. MONTEIRO, M. F. G. Gravidez cresce entre adolescentes da elite. Folha de São Paulo. São Paulo, 27 set. 2004. Cotidiano, p. C1.

74. MONTEIRO, D. L. M. et al. Modelo de assistência multidisciplinar na adolescência visando o bem estar e a contracepção. Reprodução e Climatério, São Paulo, n.10, v.2, p. 67-72, abr - jun. 1995. 
75. MORELL, M. G. G.; YAZAKI, L. M. Anticoncepção e preferências reprodutivas. In: FUNDAÇÃO SEADE. Vinte anos no ano 2000: estudos sociodemográficos sobre a juventude paulista. São Paulo: SEADE, 1998.

76. MOTT, F. L. et al .The determinants of first sex by age 14 in a high-risk adolescent population. Family Planning Perspectives; n. 28, v.1, p.13-18, 1996.

77. NELSON, P. B. Repeat pregnancy among adolescent mothers: a review of the literature. Journal of National Black Nurses Association, n.4, v1, p.28-34. 1990.

78. OLAUSSON, P. M. O.; CNATTINGIUS, S.; GOLDENBERG, R. L. Determinants of poor pregnancy outcomes among teenagers in Sweden. Obstetric Gynecology, n. 89, p.451-457, 1997.

79. OLIVEIRA, E. et al. Análise de conteúdo e pesquisa na área da educação. [on line] Disponível em www.pucsp.br/pós/ped/rsse/ac2003.pdf. Acesso em: 09 set. 2007.

80. OlIVEIRA, M. A. de C.; EMIKO Y. E. A adolescência como um constructo social. Revista Brasileira Crescimento e Desenvolvimento Humano, São Paulo, n.7, v.2, p.12-21, jul.- dez. 1997.

81. OLIVEIRA, S. O significado da gravidez para o adolescente. [on line] Disponível em: www.sbrh.med.br/boletins/bol04maio/junho/blo1o403.htm. Acesso em: 15 mai 2005.

82. OSÓRIO, L. C. Adolescente hoje. Porto Alegre: ArtMed, 1989.

83. PAIVA, V. "Sexualidade e gênero num trabalho com adolescentes para prevenção do HIV/Aids". In: PARKER, R. [e col.] (orgs.) A Aids no Brasil (1982-1992). Rio de Janeiro: Relume-Dumará/ABIA/IMS/UERJ, 1994.

84. PANTOJA, A. L. N. "Ser alguém na vida": Uma análise sócio-antropológica da gravidez/maternidade na adolescência, em Belém do Pará, Brasil. Caderno de Saúde Pública, n.19, v. 12, p. 115-122, 2003.

85. PARKER, R. (org) A Aids no Brasil (1982-1992). Rio de Janeiro: RelumeDumará/ABIA/IMS/UERJ, 1994.

86. PARKER, R. Corpos, prazeres e paixões: a cultura sexual no Brasil contemporâneo. Rio de Janeiro: Best Seller, 1991.

87. PERES, F.; ROSENBURG, C. P. Desvelando a concepção de adolescência/adolescente presente no discurso da saúde pública. Saúde e Sociedade, São Paulo, n.7, v.1, p. 53-86. 1998. 
88. PERES, S. O.; HEILBORN, M. L. Cogitação e prática do aborto entre jovens em contexto de interdição legal: o avesso da gravidez na adolescência

Caderno de Saúde Pública, Rio de Janeiro, v. 22, n. 7, p.1411-1420, 2006.

89. PERSONA, L.; SHIMO, A. K. K.; TARALLO, M. C. Perfil de adolescentes com repetição da gravidez atendidas num ambulatório de pré-natal. Revista Latino-Americana de Enfermagem, Ribeirão Preto - SP, n.12, v.5, p.745750 , out. 2004.

90. PFITZNER, M. A.; HOFF, C.; McELLIGOTT, K. Predictors of repeat pregnancy in a program for pregnant teens. Journal Pediatrics Adolescence Gynecology, n.16, v.2, p.77-81. Apr. 2003.

91. PIGOZZI, V. Celebre a autonomia do adolescente: entendendo o processo de iniciação na vida adulta. São Paulo: Gente, 2002.

92. PINTO E SILVA J. L.; NOGUEIRA C. W. M. A multigravidez na adolescência. In: Organização Pan-americana da Saúde e OMS. Coletânea sobre saúde reprodutiva do adolescente brasileiro. Brasília: Organização Panamericana da Saúde/OMS, p.101-111, 1988.

93. PIROTTA, K. C.; SCHOR, N. Intenções reprodutivas e práticas de regulação da fecundidade entre universitários. Revista Saúde Pública São Paulo, n. 38 v.4, p. 495-502, Ago. 2004:

94. PIROTTA, K. C. M. Não há guarda-chuva contra o amor: estudo do comportamento reprodutivo e de seu universo simbólico entre jovens universitário da USP. 2002. Tese (Doutorado em Saúde Pública) Faculdade de Saúde Pública, Universidade de São Paulo. São Paulo. 2002.

95. PREFEITURA MUNICIPAL DE RONDONÓPOLIS-MT/ACIR Dossiê Rondonópolis 2005: Geografia, demografia e economia, Rondonópolis-MT, Marketing Mix: 2006.

96. RAYNAUT, C. Interdisciplinaridade e promoção da saúde: o papel da antropologia. Algumas idéias simples a partir de experiências africanas e brasileiras. In Revista Brasileira Epidemiologia, São Paulo, v. 5, supl. 1, p.43-55, 2002.

97. REDE FEMINISTA DE SAÚDE Dossiê aborto inseguro. [on line]São Paulo: Rede Saúde, 1998. Disponível em: www.redesaude.org.br/Dossiês/html/abpanbrasil.html. Acesso em: 14 out. 2003.

98. REIS, A. O. A. O discurso da saúde pública sobre a adolescente grávida: avatares. 1993. Tese (Doutorado em Saúde Pública) Faculdade de Saúde Pública, Universidade de São Paulo. São Paulo.1993. 
99. REIS, A. O. A. Análise metafórico-metonímica do processo de constituição do pensamento da saúde pública acerca da adolescente grávida: os anos 60 .

Caderno de Saúde Pública, Rio de Janeiro, v.14, supl.1, p.115-123, 1998.

100.REIS, A. O. A.; ZIONI, F. O lugar do feminino na construção do conceito de adolescência. Revista de Saúde Pública, São Paulo, v.27, n.27,p.472-477, dez. 1993.

101.RIBEIRO, D. O povo brasileiro: a formação e o sentido do Brasil. São Paulo: Companhia das Letras, 1995.

102.RIETH F. Ficar e namorar. In: BRUSCHINI C.; HOLLANDA, H. B. (org). Horizontes plurais: novos estudos de gênero no Brasil. São Paulo: Ed. 34, 1998.

103.RIGSBY, D. C; MACONES, G. A; DRISCOLL, D. A Risk factors for rapid repeat pregnancy among adolescent mothers: a review of the literature. Journal Pediatrics and Adolescence Gynecology, n.11, v.3, p.115-126, aug. 1998.

104.ROMER, D. et al. Social influences on the sexual behavior of youth at risk of HIV exposure. American Journal Public Health, n. 84, v.6, p.977-985, 1994.

105.ROSA, A. J. Atendimento psicológico de adolescentes em unidade básica de saúde. In Resumos do XI Encontro Paranaense de Psicologia. Londrina-Pr. Conselho Regional de Psicologia 8 a Região, 2004. 1 CD-ROM.

106.RUA, M. G.; ABRAMOWAY, M. Avaliação das ações de prevenção às DST/Aids e uso indevido de drogas nas escolas de ensino fundamental e médio em capitais brasileiras. Brasília: UNESCO/Ministério da Saúde, Grupo temático UNAIDS/UNODC, 2001.

107.RUGOLO, L. M. S. S. et al. Sentimentos e percepções de puérperas com relação à assistência prestada pelo serviço materno-infantil de um hospital universitário. Revista Brasileira de Saúde Materno Infantil, Recife, n.4, v.4, p.423-433, out.- dez. 2004.

108.SANTINI DE ALMEIDA, M. A. Gravidez adolescente: a diversidade das situações. Revista Brasileira de Estudos da População, São Paulo, v.19, n.2, jul. - dez. 2002.

109.SCHOR, N. Adolescência e anticoncepção: Conhecimento e uso. 1995. (Livre docência em Saúde Pública) Faculdade de Saúde Pública, Universidade de São Paulo. São Paulo. 1995.

110.SILVA, D. G. V.; TRENTINI, M. Narrativas como técnica de pesquisa em enfermagem. Revista Latino-americana de Enfermagem, Ribeirão Preto, v.10, p. 423-432, 2002. 
111.SIMÕES, V. M. F. et al. Características da gravidez na adolescência em São Luís, Maranhão. Revista de Saúde Pública, São Paulo, n.37, v.5, p.559-565, out.2003.

112.SIQUEIRA, M. J. T. et al .Profissionais e usuárias(os) adolescentes de quatro programas públicos de atendimento pré-natal da região da grande Florianópolis: onde está o pai? Estudo de Psicologia, Natal, n.7, v.1, p.65-72. jan. 2002

113.SISPRENATAL Sistema de Acompanhamento do Programa do Programa de Humanização no Pré-Natal e Nascimento. Secretaria Municipal de Saúde do município de Rondonópolis-MT: 2007.

114.STEVENS-SIMON, C.; PARSONS, J.; MONTGOMERY, C. What is the relationship between postpartum withdrawal from school and repeat pregnancy among adolescent mothers? Journal Adolescence Health Care, n. 7, v.3, p.191-194, may. 1986.

115.STEVENS-SIMON, C; KELLY, L.; KULICK, R. A village would be nice but" it takes a long-acting contraceptive to prevent repeat adolescent pregnancies. American Journal of Preventive Medicine, n.21, n.1, p.60-65. jul. 2001.

116.STEVENS-SIMON, C; KELLY, L; SINGER, D. Absence of negative attitudes toward childbearing among pregnant teenagers: a risk factor for a rapid repeat pregnancy? Archives of Pediatric \& Adolescence Medicine; n.150, p. 10371043, 1996.

117.TAKIUTI, A. D. Projeto de prevenção da segunda gestação na adolescência no Estado de São Paulo. Secretaria de Estado da Saúde de São Paulo Programa de Saúde do Adolescente. 2004. (Mat. digitado)

118.TAKIUTI, A. D. Gravidez na Adolescência diminui 28\% no Estado In Jornal Estado de São Paulo, 22 jun. 2005, p. A 18.

119.TESORO, L. L. L. M. Rondonópolis-MT: um entroncamento de mão única. São Paulo: LLLMT, 1993.

120.UNICEF Relatório da Situação da Adolescência Brasileira. UNICEF Brasil: Brasília, 2003.

121.VARELLA, D. Gravidez indesejada e violência urbana In Folha de São Paulo. São Paulo, 04 set. 2004. Ilustrada. p. E8.

122.VENTURA, S. J. et al. Births: final data for 1998. National Vital Statistics Reports, n. 48, p.88-100, 2000.

123.VERMELLO, L. L. Mortalidade de jovens: Análise do período de 1930 a 1991; a transição epidemiológica para a violência. 1994. Tese (Doutorado em 
Saúde Pública) Faculdade de Saúde Pública, Universidade de São Paulo. São Paulo.1994.

124.WERNER-WILSON, R. J. Gender Differences in adolescent sexual attitudes: the influence of individual and family factors. Adolescence. n. 33, p.518-531, 1998.

125.WHO (World Health Organization) Sexual relations among young people in developing countries: evidences from case studies. Genebra: WHO, 2001.

126.WHO (World Health Organization) Adolescent friendly health services: an agenda for change. Genebra: WHO, 2002.

127.WHO (World Health Organization) Adolescent pregnancy: issues in adolescent health and development. Genebra: WHO, 2004.

128.YAZAKI, L. M.; MORELL, M. G. G. Fecundidade é antecipada. In: FUNDAÇÃO SEADE. Vinte anos no ano 2000: estudos sócio-demográficos sobre a juventude paulista. São Paulo: SEADE, 1998. 


\section{ANEXO I}

\section{QUESTIONÁRIO SÓCIO-ECONÔMICO}

Entrevistador

Data: 2007.

Codificação da entrevistada:

Data de nascimento: .................. Idade: ......anos e ....meses.

Endereço: $\mathrm{n}^{\mathrm{o}}$ :

Município: Rondonópolis-MT

Bairro:

\section{1 - CARACTERÍSTICAS DA UNIDADE DOMICILIAR:}

1.1 - Qual é o tipo de domicilio em que reside?
- Casa
- Apartamento
- Cômodo

1.2 - Qual o material que predomina na construção das paredes externas da edificação?

- Alvenaria

- Madeira

- Outros:

1.3 - Quantos cômodos têm o domicílio? .... cômodos

1.4 - Quantos cômodos estão servindo permanentemente de dormitório?

1.4.1 - Quantas pessoas moram na casa?

1.5 - O domicílio é:

- Da família - Alugado (se alugado, qual o valor: R\$

- Cedido

1.6 - O domicílio possui água:

- Encanada

- De poço

- Outro:

1.7 - O domicílio possui:

- Rede coletora de esgoto

- Fossa - Outro:

1.8 - O lixo do domicílio é:

- Coletado diretamente

- Jogado em terreno baldio - Outro:

1.9 - Qual é a forma de iluminação do domicílio?

- Energia elétrica - Querosene - Outro:

1.10 - Tem telefone móvel celular?

- Sim - Não

1.11 - Tem telefone fixo convencional?

- Sim - Não

1.12 - O fogão usado no domicílio utiliza:

-gás - lenha

1.13 - No domicílio tem algum tipo de filtro d’água? 
- Sim

- Não

1.14 - No domicílio tem televisão?

- Sim - Não

1.15 - No domicílio tem rádio?

- Sim - Não

1.16 - No domicílio tem geladeira?

- Sim - Não

1.17 - No domicílio tem máquina de lavar roupa?

- Sim - Não

1.18 - No domicílio tem microcomputador?

- Sim, com acesso à internet - Sim - Não

- Não

1.19 - Alguém que resida no domicílio possui automóvel?

- Sim. Qual tipo?

-Não

\section{2 - CARACTERÍSTICAS GERAIS DA ADOLESCENTE}

2.1 - Em relação ao responsável pelo domicílio, qual a condição da entrevistada?

- Esposa

- Filha

- Amiga

- Nora

- Cunhada

- Outra:

2.2 - Que cor atribui à sua pele?

- Negra

2.3 - Nasceu em Rondonópolis-MT?

- Sim - Não, onde:

2.4 - A mãe nasceu em Rondonópolis-MT?

- Sim - Não: onde:

2.5 - Com que idade a mãe ficou grávida pela primeira vez? Quantos filhos a mãe tem?

2.6 - O pai nasceu em Rondonópolis-MT

- Sim - Não: onde:

2.7 - Completou qual série?

2.8 - Interrompeu os estudos?

- Não

- Sim. Se, saiu da escola, qual foi o motivo?

- Se, saiu da escola, quais as dificuldades para você voltar a estudar? 
2.9 - Repetiu alguma série na escola?

- Sim. Qual?

- Não

2.10 - Já fez algum curso profissionalizante?

- Sim, qual:

- Não

2.11 - Que profissão gostaria de ter?

\section{3 - CARACTERÍSICAS DE TRABALHO E RENDA DA ADOLESCENTE}

3.1 - Já teve algum trabalho remunerado?

- Sim. Qual era a ocupação? Se permanece trabalhando, qual a sua ocupação atual?

- Não

3.2 - Depende da renda de alguém?

- Sim. De quem? Qual a sua ocupação?

E rendimento mensal? $\quad-1$ a 2 salários $\quad-3$ a 4 salários $\quad-5$ a 6 salários $\quad$ - + de 7 salários

- Não. Quanto é a sua renda? ? - - 1 a 2 salários — - 3 a 4 salários $\quad$ - 5 a 6 salários _ - + de 7 salários

3.3 - Quantas pessoas do seu domicílio trabalham?

3.4 - Qual o total da renda das pessoas com as quais convive?

-1 a 2 salários - 3 a 4 salários - 5 a 6 salários - + de 7 salários

3.5 - Foi beneficiária de algum programa governamental:

( ) Não ( ) Sim -Bolsa escola - Bolsa Família - Outro:

\section{4 - ACESSO A BENS PÚBLICOS}

4.1 - Você ficou sem estudar alguma vez por falta de vaga?

4.2 - Você ficou sem consulta médica alguma vez?

4.3 - Você acha que a Unidade de Saúde está longe da sua casa?

4.4 - Como você avalia os atendimentos que está recebendo no pré-natal:

a) do médico;

b) da enfermeira;

c) dos agentes de saúde;

d) da recepção da Unidade de Saúde. 


\section{ANEXO II \\ ROTEIRO DE ENTREVISTA SEMI-ESTRUTURADA}

Entrevistador:

Datas dos encontros:

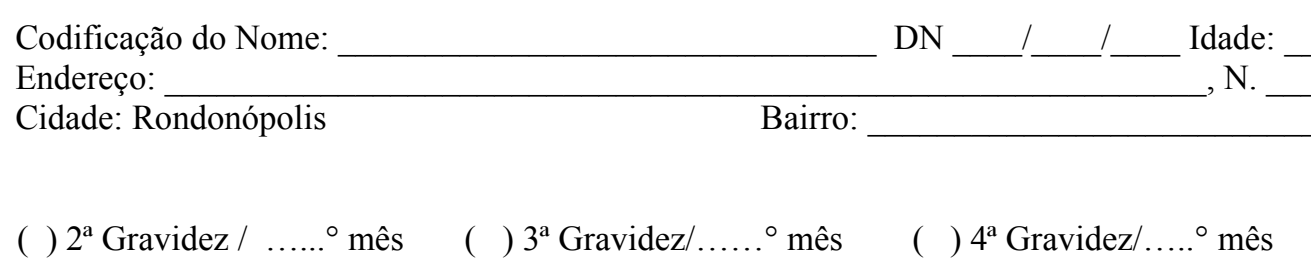

Árvore genealógica

1 - Contexto afetivo

1.1 - Gostaria que você me contasse sobre seu pai.

1.2 - Gostaria que você me contasse sobre sua mãe.

\section{2 - Contextos "iniciação sexual"}

2.1 - Como você foi descobrindo as "coisas" sobre sexo?

2.2 - O que você sabia sobre a menstruação quando "veio" pela primeira vez?

2.2.1 - Que idade você tinha quando "veio" a primeira menstruação?

2.3 - Como "aconteceu" a sua primeira relação sexual?

2.3.1 - Que tipo de relacionamento você mantinha com o parceiro?

2.3.2 - Quantos anos você tinha?

2.3.3 - Você usou preservativos na primeira relação sexual?

2.3.4 - Você usava anticoncepcional quando ocorreu a primeira relação sexual.

2.3.5 - Que tipo de relação você mantinha com o parceiro da iniciação sexual?

\section{3 - Contexto vida sexual/reprodutiva na $1^{\text {a }}$ maternidade}

3.1 - Você queria ficar grávida?

3.1.1 - Você usou algum método anticoncepcional antes da primeira gravidez?

3.2 - Quanto tempo levou para ficar grávida após ter iniciado a vida sexual?

3.2.1 - Quantos parceiros sexuais você teve antes da primeira gravidez?

3.2.2 - Entre o início da vida sexual e a primeira gravidez, o relacionamento mais duradouro, durou quanto tempo? 
3.2.3 - Relacionava-se sexualmente com o pai do bebê quando ficou grávida havia cerca de quanto tempo?

3.2.4 - Até a gravidez, manteve ( )uma ( ) poucas ( )muitas relação (ões) sexual (is) com ele.

3.2.5 - Ficou sabendo que estava grávida após .......mês (es) de gestação.

3.2.6 - Quantos anos você tinha ao ficar grávida pela $1^{\mathrm{a}}$ vez?

3.3 - Qual foi sua maior preocupação quando foi confirmada a gravidez?

3.3.1 - Escondeu a gravidez?

3.3.2 - Para quem contou primeiro?

3.3.3 - Quanto tempo levou para contar ao parceiro?

3.3.4 - Qual foi a reação do parceiro ao saber da gravidez?

3.3.5 - Qual a idade do pai do bebê quando ficou grávida pela $1^{\mathrm{a}}$ vez?

3.4 - Você pensou em fazer aborto?

3.5 - Fez pré-natal? ( ) Não ( ) Sim, iniciou no.... mês de gravidez. No/consultas.....

3.6 - Quais foram as dificuldades da gravidez?

3.7 - Bebê nasceu com .... semanas, após parto: Normal ( ） Cesário ( )

\section{4 - Contexto paternagem na $1^{\text {a }}$ maternidade}

4.1 - Qual foi a participação do parceiro?

a) durante a gestação.

b) no dia do parto.

c) durante o pós-parto.

d) atualmente.

4.2 - Como é o relacionamento do pai do seu filho com a sua família?

\section{5- Contexto participação da família na $1^{\mathrm{a}}$ maternidade}

5.1 - Qual foi a participação dos seus familiares?

a) durante a gestação.

b) no dia do parto.

c) durante o pós-parto.

d) atualmente.

\section{6 - Contexto maternagem na $1^{\mathrm{a}}$ maternidade}

6.1 - Você "brincou" com seu bebê durante a gestação?

6.2 - Você amamentou?

6.3 - Como foi trocar fraldas do bebê?

6.4 - O que mudou na sua vida com o $1^{\circ}$ filho?

\section{7 - Contexto vida sexual/reprodutiva na $2^{\mathrm{a}}$ maternidade}

7.1 - Você queria ficar grávida pela $2^{\mathrm{a}}$ vez?

7.1.1 - Usou algum método anticoncepcional entre o $1^{\circ}$ parto e a $2^{\mathrm{a}}$ gravidez?

7.2 - Quanto tempo levou para ficar grávida novamente após $01^{\circ}$ parto? 
7.2.1 - Manteve parceria sexual fixa entre o $1^{\mathrm{o}}$ parto e a $2^{\mathrm{a}}$ gravidez?

7.2.2 - Relacionava-se sexualmente com o pai do seu $2^{\circ}$ filho quando ficou grávida havia cerca de quanto tempo?

7.2.3 - Até a gravidez, manteve ( ) )uma ( ) poucas ( )muitas relação (ões) sexual (is) com ele.

7.2.4 - Ficou sabendo que estava grávida após .......mês(es) de gestação.

7.2.5 - Quantos anos você tinha ao ficar grávida pela $2^{\mathrm{a}}$ vez?

7.3 - Qual foi sua maior preocupação quando foi confirmada a $2^{\mathrm{a}}$ gravidez?

7.3.1 - Escondeu a gravidez?

7.3.2 - Para quem contou primeiro?

7.3.3 - Quanto tempo levou para contar ao parceiro?

7.3.4 - Qual foi a reação do parceiro ao saber da gravidez?

7.3.5 - Ao ficar grávida pela $2^{\mathrm{a}}$ vez, que tipo de relação mantinha com o parceiro?

7.3.6 - Qual a idade do parceiro quando ficou grávida pela $2^{\mathrm{a}} \mathrm{vez}$ ?

7.4 - Você pensou em fazer aborto na $2^{\mathrm{a}}$ gravidez?

7.5 - Fez pré-natal? ( ) Não ( ) Sim, iniciou no “““ mês de gravidez. N\%/consultas .....

7.6 - Quais foram as dificuldades da $2^{\mathrm{a}}$ gestação até agora?

7.7 - Pretende fazer parto: Normal ( ) Cesariana ( )

(quando houve a $3^{a}$ gravidez)

7.6 - Quais foram as dificuldades da $2^{\mathrm{a}}$ gestação?

7.7 - Bebê nasceu com ........ semanas, após parto: Normal ( ） Cesáreo ( )

\section{8 - Contexto paternagem na $2^{a}$ maternidade}

8.1 - Qual foi a participação do parceiro?

a) durante a gestação.

(quando houver a $3^{a}$ gravidez)

b) no dia do parto.

c) durante o pós-parto.

d) atualmente.

8.2 - Como é o relacionamento do pai do bebê com a sua família?

\section{9 - Contexto participação da família na $2^{\mathrm{a}}$ maternidade}

9.1 - Qual foi a participação dos seus familiares?

a) durante a gestação.

(quando houver a $3^{a}$ gravidez)

b) no dia do parto.

c) durante o pós-parto.

d) atualmente.

10 - Contexto maternagem na $2^{\text {a }}$ maternidade (quando houver a $3^{a}$ gravidez) $^{2}$

10.1 - Você "brincou" com seu bebê durante a gestação?

10.2 - Você amamentou?

10.3 - Como foi trocar fraldas do bebê? 
10.4 - O que mudou na sua vida com o $2^{\circ}$ filho?

\section{1 - Contexto vida sexual/reprodutiva na $3^{\mathrm{a}}$ maternidade}

11.1 - Você queria ficar grávida pela $3^{\mathrm{a}}$ vez?

11.1.1 - Usou algum método anticoncepcional entre o $2^{\circ}$ parto e a $3^{\mathrm{a}}$ gravidez?

11.2 - Quanto tempo levou para ficar grávida após o $2^{\circ}$ parto?

11.2.1 - Quantos parceiros sexuais você teve após o $2^{\circ}$ parto e a $3^{\mathrm{a}}$ gravidez?

11.2.2 - Relacionava-se sexualmente com o pai do seu $3^{\circ}$ filho quando ficou grávida havia cerca de

11.2.3 - Até a gravidez, manteve ( )uma ( ) poucas ( )muitas relação (ões) sexual (is) com ele.

11.2.4 - Você ficou sabendo que estava grávida após ......mês(es) de gestação.

11.2.5 - Quantos anos você tinha ao ficar grávida pela $3^{\mathrm{a}}$ vez?

11.3 - Qual foi sua maior preocupação quando foi confirmada a $3^{\mathrm{a}}$ gravidez?

11.3.1 - Escondeu a gravidez?

11.3.2 - Para quem contou primeiro?

11.3.3 - Quanto tempo levou para contar ao parceiro?

11.3.4 - Qual foi a reação do parceiro ao saber da gravidez?

11.3.5 - Ao ficar grávida pela $3^{\mathrm{a}}$ vez, que tipo de relação mantinha com o parceiro?

11.3.6 - Qual a idade do parceiro quando ficou grávida pela $3^{\mathrm{a}}$ vez?

11.4 - Você pensou em fazer aborto na $3^{\mathrm{a}}$ gravidez?

11.5 - Fez pré-natal? ( ) Não ( ) Sim, iniciou no ....... mês de gravidez. No/consultas.....

11.6 - Quais foram as dificuldades da $3^{\mathrm{a}}$ gestação até agora?

11.7 - Pretende fazer parto: Normal ( ) Cesário ( )

(quando houver a $4^{a}$ gravidez)

11.6 - Quais foram as dificuldades da $3^{\mathrm{a}}$ gestação?

11.7 - Bebê nasceu com ........ semanas, após parto: Normal （ ） Cesário （ ）

\section{2 - Contexto paternagem na $3^{\text {a }}$ maternidade}

12.1 - Qual foi a participação do parceiro?

a) durante a gestação.

(quando houver a $4^{a}$ gestação)

b) no dia do parto.

c) durante o pós-parto.

d) atualmente.

12.2 - Como é o relacionamento do pai do bebê com a sua família?

\section{3 - Contexto participação da família na $3^{\mathrm{a}}$ maternidade}

13.1 - Qual foi a participação dos seus familiares?

a) durante a gestação.

(quando houver a $4^{a}$ gestação)

b) no dia do parto.

c) durante o pós-parto.

d) atualmente. 


\section{ANEXO III \\ TERMO DE CONSENTIMENTO LIVRE E ESCLARECIDO}

Esse documento tem o objetivo de informar-lhe sobre as condições e garantia de seus direitos ao aceitar participar de uma pesquisa.

Você está sendo convidada a participar como voluntária da pesquisa Novamente grávida: Adolescentes com maternidades sucessivas em Rondonópolis MT. Tem o objetivo de caracterizar e analisar as condições de vida e individuais de adolescentes de 15 a 19 anos, com mais de uma gravidez, residentes no município de Rondonópolis-MT.

A sua participação nesse estudo é livre e voluntária. Você pode se recusar a participar. Se aceitar participar da pesquisa, você tem o direito de desistir e retirar seu consentimento a qualquer momento, inclusive, no transcorrer de alguma etapa, sem prejuízo algum para você. Se você aceitar, deve assinar uma das vias desse documento e então, receberá uma cópia desse termo.

Eu posso tirar suas dúvidas, agora e em outros momentos. Para isso, você pode ligar a cobrar para Alcindo José Rosa - Tel.: 90xx(66) 34229420 ou para o Orientador desta pesquisa, Professor Alberto Olavo Adv. Reis - Tel.: 90xx(11) 30667126.

Se você aceitar participar da pesquisa, realizarei uma entrevista sobre sua vida Agendaremos os encontros e os realizaremos em seu domicílio ou se preferir, na Unidade de Saúde. A duração de cada atividade será de cerca de 1 hora.

Suas informações serão estudadas e servirão para: 1 - conhecer melhor os contextos em que ocorrem várias gravidezes na adolescência e, 2 - propor políticas públicas de atenção às adolescentes.

Não está previsto benefícios diretos a você por participar desta pesquisa, assim como não está previsto qualquer dano à sua integridade física, social e emocional. Por ventura, se nas entrevistas ou no teste, algum desconforto moral/emocional ocorrer ou for por você revelado, está desde já lhe assegurado que poderá ser atendida pelo Centro de Práticas Psicológicas da Universidade Federal do Mato Grosso/Rondonópolis-MT. Você não terá nenhum gasto por participar, assim como também não receberá nenhum pagamento.

As informações pessoais obtidas por meio desta pesquisa serão confidenciais e asseguro o sigilo sobre elas. Os dados jamais serão divulgados de forma que possibilitem sua identificação. Todos os materiais relativos a você permanecerão devidamente guardados sob meus cuidados. Todas as informações serão utilizadas somente para os propósitos desta pesquisa, sendo que você terá liberdade de acesso aos resultados. Se você tiver menos de 18 anos, precisarei da autorização de seu responsável legal.

Alcindo José Rosa - Pesquisador responsável 


\section{CONSENTIMENTO DE PARTICIPAC̣ÃO}

$\mathrm{Eu}$, , RG.

declaro que li as informações contidas nesse documento, e que fui devidamente informada pelo pesquisador Alcindo José Rosa sobre os procedimentos que serão utilizados, riscos e desconfortos, benefícios, custo/reembolso e confidencialidade da pesquisa, e concordo em participar da pesquisa. Foi-me garantido que posso retirar o consentimento a qualquer momento, sem que isso me prejudique. Declaro ainda que recebi uma cópia desse Termo de Consentimento.

Rondonópolis, 2007

(Assinatura)

\section{CONSENTIMENTO DO RESPONSÁVEL}

$\mathrm{Eu}$, RG. declaro que li as informações contidas nesse documento, e que fui devidamente informado pelo pesquisador Alcindo José Rosa sobre os procedimentos que serão utilizados, riscos e desconfortos, benefícios, custo/reembolso e confidencialidade da pesquisa, e concordo que ,RG. , da qual sou responsável legal, participe da pesquisa citada acima. Foi-me garantido que ela pode ou eu poderei retirar o consentimento a qualquer momento, sem que isso traga prejuízo a ela ou a mim. Declaro ainda que recebi uma cópia desse Termo de Consentimento.

Rondonópolis, 2007.

(Assinatura) 


\section{ANEXO IV}

GEOPROCESSAMENTO DA LOCALIZAÇÃO DAS RESIDÊNCIAS DE ADOLESCENTES COM MATERNIDADES SUCESSIVAS NA CIDADE DE RONDONÓPOLIS-MT, 2007

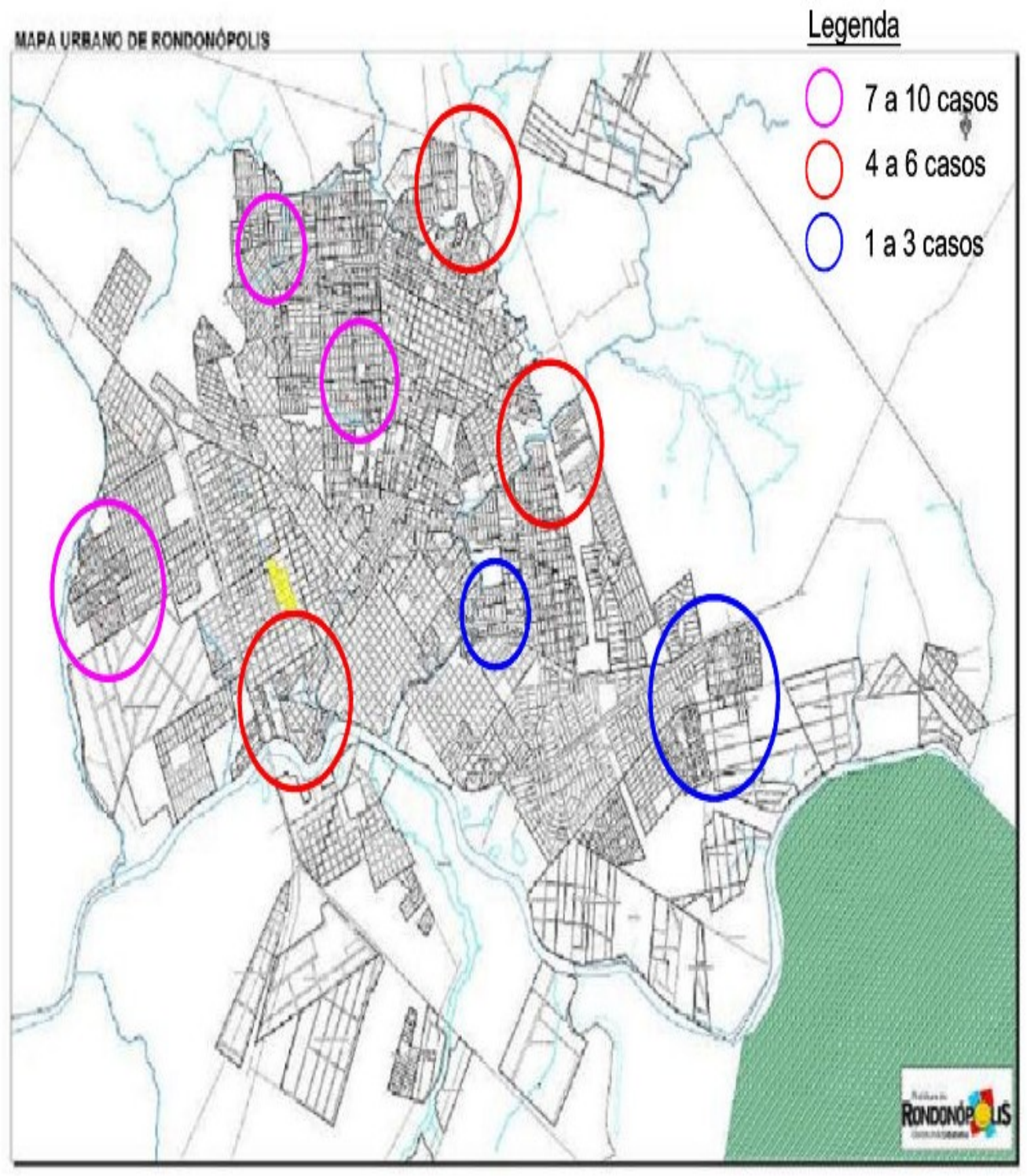

